두 

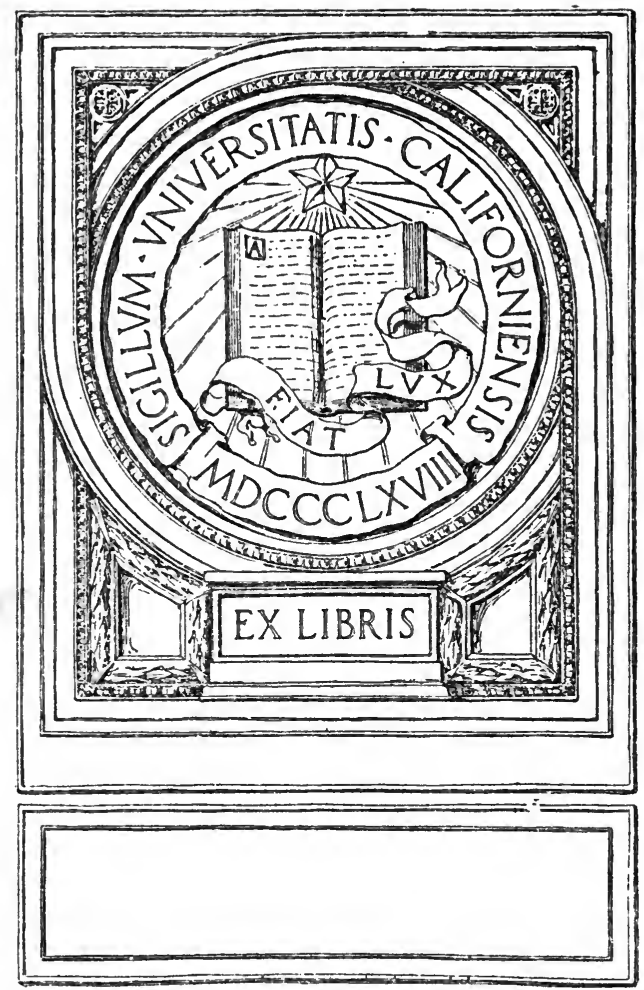


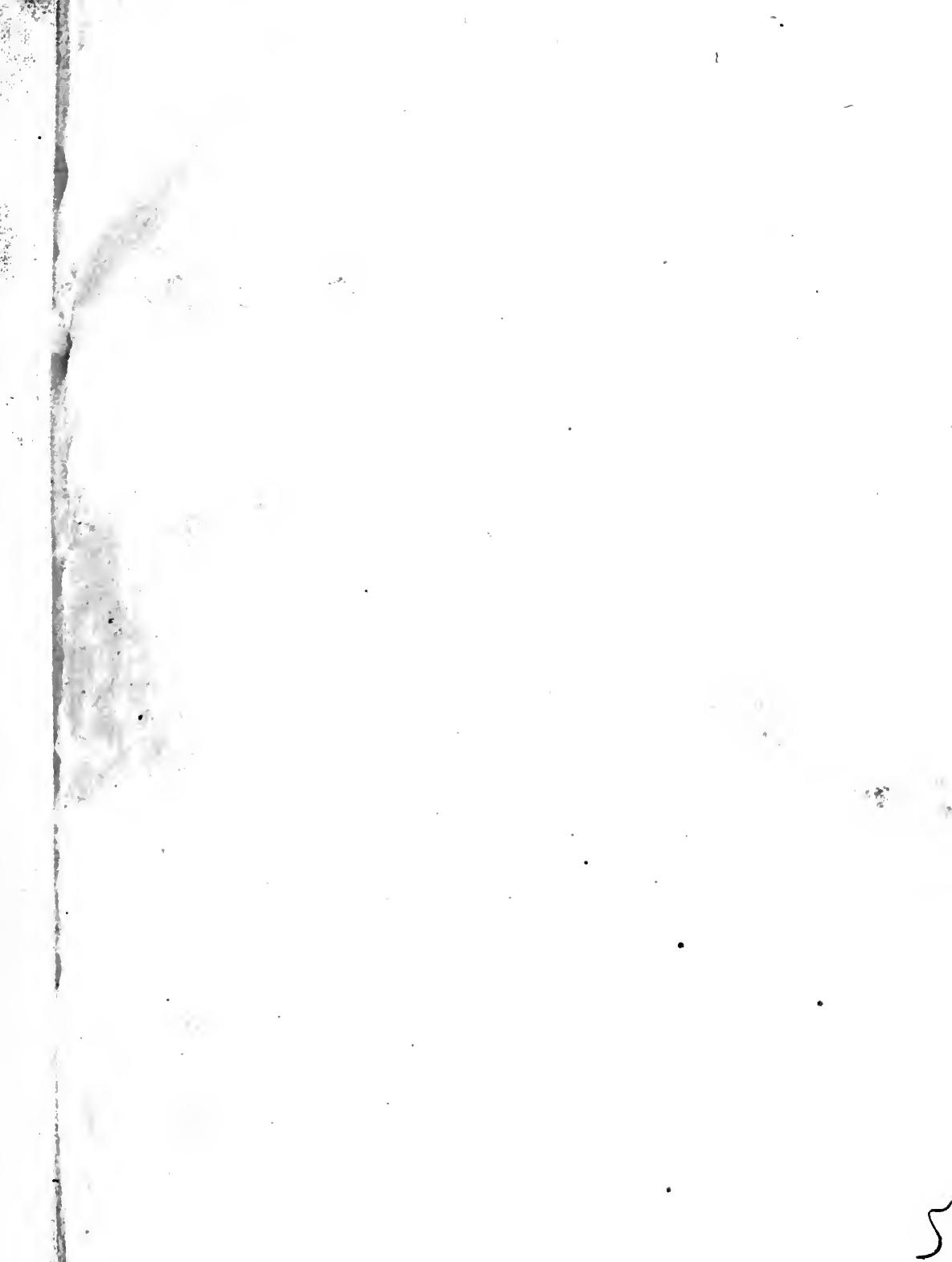

5

18

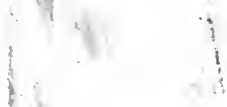


Digitized by the Internet Archive in 2007 with funding from

- Microsoft Corporation 
PROBLEMS OF MODERN INDUSTRY 



\section{PROBLEMS OF MODERN}

\section{INDUSTRY BY SIDNEY}

\& BEATRICE WEBB

NEW EDITION

LONGMANS, GREEN AND CO. FOURTH AVENUE \& 30TH STREET, NEW YORK 39 PATERNOSTER ROW, LONDON BOMBAY, CALCUTTA, AND MADRAS I 920

(Fifth Thousand, 1920.) 
Replucory. 102128

HD8390

W3

1902 


\section{PREFACE TO THE ISSUE OF I920}

THE authors of these studies had not contemplated reprinting them. But there continues to be a demand for them, even after a couple of decades; and it seems ungracious to let them go out of print, imperfect as they are. We therefore reissue them uniform, not only with our Industrial Democracy, in which the theory and practice of Trade Unions is analysed in detail, but also with our History of Trade Unionism, in the revised and greatly enlarged edition, in which the story is brought down to 1920 .

It is interesting, at least to the authors, to trace in these essays of the nineteenth century the forecasts of the solutions which the twentieth century is accepting. With regard to Women's Wages, dealt with in Chapter III., the reader may be referred to the elaborate Report of the War Cabinet Committee on Women in Industry, I9I9; and especially to the Minority Report by one of ourselves, which has been separately published under the title of Men's and Women's Wages: Should they be Equal ? ${ }^{1}$

The once-disputed question of the propriety of legal regulation of the conditions of employment, dealt with in Chapters IV. and V., is no longer a matter of controversy among educated people, though each particular application

1 Fabian Bookshop, 25 Tothill Street, Westminster; or George Allen and Unwin, Limited, price Is. net. 
of the principle still meets with opposition among the uninstructed. The analysis of the economic and social effects of legal regulation, as contrasted with those of the absence of regulation on the one hand, and those of regulation by voluntary association on the other, is given in great detail in our Industrial Democracy. We should explain, for the benefit especially of readers in the United States and other countries in which the desirability of legal regulation is not yet fully accepted, either by some of the men's Trade Unions or by the employers and legislators, that the authors retain the view that Factory Laws applicable to women only are better, even in the women's interests, than no Factory Laws at all; and that 'the fear of women's exclusion from industrial employment,' as a result of such one-sided and imperfect legislation, 'is wholly unfounded.' A quarter of a century of further experience confirms the conclusion that the effect of such legislation is, 'by encouraging machinery, division of labour and production on a large scale, to increase the employment of women, and largely to raise their status in the labour market.' In countries where more comprehensive Factory Legislation cannot, for the moment, be obtained, it is in 1920 even more desirable than it was in 1895 , that legislative regulation of the conditions of women's employment should be obtained. We have seen in Great Britain during the past decade, how true was the conclusion that ' with this regulation, experience teaches us that women can work their way in certain occupations to a man's skill, a man's wages, and a man's sense of personal dignity and independence.' Wherever, as in the United Kingdom, the men's Trade Unions and instructed public opinion accept Factory Legislation as desirable, there is, of course, no reason for any one-sided treatment; and Factory Laws 
should not be differentiated, any more than Standard Rates of Payment, by sex, race or the colour of the hair.

In Chapter VII. the reader may detect an imperfect foreshadowing of the elaborate Minority Report of the Royal Commission on the Poor Law, I909; republished without its bewildering but instructive footnotes and references, with introductions by ourselves, as The Break-Up of the Poor Law and The Public Organisation of the Labour Market. ${ }^{1}$ State Pensions for the Aged were granted, imperfectly, in 1908 ; and the British Government expressly pledged itself in I9I9, as a Parliamentary bargain by which it secured the passage of the Ministry of Health Bill, to the immediate Abolition of the Poor Law, and the distribution of its services among the several committees of the local municipal authorities, to be conducted under the Education, Public Health, Mental Deficiency, Old Age Pensions and Unemployment Acts, as proposed, ten years before, in the Minority Report. Each year's postponement of this farreaching reform is involving a waste of millions of pounds, and doing incalculable social harm.

If the reader is alive to the acute controversy that now exists, not in Great Britain only, but also, under other forms of words, among whole sections of the population of most European countries (though scarcely at all as yet among those who fill the places of statesmen), as to the form in which the Democratic governments of the future should be cast, he should weigh Chapter VIlI. In that popular exposition of the relation between Co-operation and Trade Unionism, dating as far back as I892, will be found the contrast between the nature and functions of Associations of Consumers and Associations of Producers respectivelyterms which are gradually coming into the consciousness of

1 Longmans, Green \& Co., price, respectively, 7s. 6d. net and 5s. net. 
those whose duty it is to scrutinise the evolution of Democracy. The authors do not believe to-day, any more than they did in I 892, that the government and control of industry can, or even will, be in the future vested wholly in the Democracy of Producers, whether self-governing workshop, Trade Union, Gild or factory soviet, any more than it can be allowed to be vested in a class of private employers or an employers' association. On the other hand, they recognise, as they explained in 1897 in their Industrial Democracy, that it is equally impossible to attain either the highest productivity or that fullest development of individual faculty which we mean by freedom, where the govern. ment and control of industry is trusted exclusively to the Democracy of Consumers, whether Co-operative Society, Municipality or completely democratised National Government. We believe now, as we said in 1892 , that, for any genuinely efficient Democracy, both forms must coexist, and be fully recognised-the Association of Consumers and the Association of Producers each having its own lawful and necessary sphere of power and influence, and each working continuously in full activity. The 'proper relationship' between them, as was indicated in 1892 , is 'that of an ideal marriage, in which each partner respects the individuality and assists the work of the other, whilst both cordially join forces to secure their common end-the Co-operative State.'

SIDNEY WEBB.

BEATRICE WEBB. 


\section{INTRODUCTION TO THE I9O2 EDITION}

A VOLUME which continues for over four years to find a steady sale may be assumed to meet the needs of some part of the world. We have therefore not hesitated, in spite of our consciousness of manifold imperfections, to allow the publication of a cheaper edition of these collected essays, uniform with the 1902 editions of our History of Trade Unionism and Industrial Democracy.

The opening of the twentieth century finds both England and the United States in a state of acute selfconsciousness with regard to the organisation of industry and commerce, and the influence of financial considerations in national politics. The last decade has witnessed important and even dramatic changes in the economic organisation of the civilised world. These changes have, both in the United Kingdom and the United States, produced a marked effect on the public imagination. Public opinion learns, it is to be feared, little from books, and only occasionally absorbs a discovery in the realm of thought. Its most effective teacher is always some objective happening in the world of things. The English municipalities learned the elements of sanitation, not from the physiologists, but from three successive visitations of Asiatic cholera. The economic changes of the last few years - the scramble for Africa, the territorial expansion of the United States, the enormous development of individual 
fortunes, the 'internationalisation' of every branch of industry, and, above all, the startling multiplication of syndicates, trusts, and giant amalgamations-all these have worked a great change in the mind of the electorate. In the new Introductions to the current editions of the History of Trade Unionism and Industrial Democracy we have described some of these developments of public opinion, with special reference to trade unions and strikes. We now add a few suggestions with regard to Trusts, and the public alarm concerning them. ${ }^{1}$

It is curious to notice with what a start the ordinary citizen has all of a sudden realised how entirely both England and the United States have departed from the industrial organisation described by the classic economists. Adam Smith's Wealth of Nations and the Declaration of Independence were given to the world in the same year. We need not here inquire to what extent the argument and philosophy of both these masterpieces may have been influenced by the industrial organisation then common to England and New England. What is brought vividly and dramatically to our minds by the formation of the so-called 'Billion Dollar Steel Trust' and the 'Atlantic Shipping Combine'. is the extent of the change which has come over the economic status of the mass of the nation. A century and a quarter ago, when Jefferson and Adam Smith were writing, it could be taken for granted that the normal state of things was for every man to become, in due course, 'his own master'; it could be assumed that the work of the world was, for the most part, done by men who were moved by the stimulus of making 'profit' as distinguished from wages or salary; it seemed a scientific fact that values were determined by the mutual exchange of the commodities and services of independent producers. It was on these assumptions that the classic political economy was based. What is

1 Much of the substance of this Introduction appeared in The International Monthly for February 1902, and we are indebted to the editor for permission to reproduce it. 
more important to us to-day is that, both in England and in the United States, the public opinion of the educated and prosperous classes still makes, with regard to haif its judgments, much the same assumptions. Neither the prosperous Englishman nor the prosperous American can rid himself of the feeling that it is open to every one to become a profit-maker, that no one need long remain a mere wage-earner, and that it is therefore not really of vital consequence to the nation how those members of the community who happen temporarily to be wage-earners are actually living. The opening of the twentieth century sees, perhaps, some weakening of this assumption. England pays more and more attention to its factory legislation. The prosperous American still believes, however, that at any rate every native-born American can rise to a higher place, and that the status of the hired labourer is therefore, on the American continent, still something transient, exceptional, and relatively unimportant. $\mathrm{He}$ is still revolted by any glimpse of American democracy as a 'democracy of the "hired man." Yet surely nothing is more certain than that in the United States, as in Western Europe and Australia, the hired men form, and must necessarily continue to form, at least three-fourths of the population. This is a fact which the advent of the Trust, the supremacy of business conducted on a large scale, the rapidly increasing concentration of nearly every kind of industry, can hardly fail to drive home to the mind of the American, as to that of the English citizen. $\mathrm{He}$ will, for the first time, become aware of himself as one of a democracy of hired men.

We shall be conscious, too, by whom we are hired. It has long been a fond dream, both in England and in the United States, to prove, by some mysterious juggling with wage and price statistics; that wealth is getting more equally distributed, that the proportion of small competences is increasing, and that the number is growing of those who, as shareholders or interest receivers, share in industrial profits. This has, for forty or fifty years, been an amiable delusion 
of the statistical philanthropist. It is now dispelled, The dramatic concentrations of capital exhibited by the Rockefellers and Pierpont Morgans, like the visible accumulations of some English ducal ground-landlords, have forced upon everybody's notice the indisputable testimony of deathduty statistics. The only point in dispute is whether wealth-concentration has as yet gone further in England or in the United States. This is, of course, not to deny that some or all of the property-less masses have, during the past fifty years, found their conditions of life improved. But the advent of the Trust is making both England and America realise, as they have never realised before, that in both countries nine-tenths of all the realised property belongs to-day to a class that comprises only one-tenth of the population,- that ninety per cent of the citizens, the great mass of the people, share among them, even including their little homes and furniture, and all their much-vaunted hoards, the ownership of not more than ten per cent of the capital wealth.

But if the advent of the Trust makes us conscious of ourselves as nations of hired men, it necessarily compels us to realise that the conditions of our hiring are all-important, not only to ourselves individually, but to the community as a whole. 'Every society is judged,' as Mr. Asquith, the late Home Secretary, said the other day,-' and survives, according to the material and moral minimum which it prescribes to its members.' Note that word 'prescribes.' As hired men, we find ourselves graded in elaborate hierarchies, from the sweated trouser-hand or day-labourer, right up to Mr. Schwab or Mr. Clinton Dawkins at fabulous salaries. But the census. shows four-fifths of us to be manual-working wage-earners, keeping our families out of earnings which may be anything from ten shillings to ten pounds a week. These earnings depend on our successful bargaining with our employers, employers who used to be men like ourselves, but who, as we now realise, are, for the majority of us, gigantic capitalist corporations, huge joint-stock mills, railways, shipping combines, 
and 'Billion Dollar Steel Trusts.' Between these employers and the individual workmen there has hitherto been assumed to be 'freedom of contract,' secured to us by the Constitution of the United States or by the contemporary general principles of the law in the United Kingdom; and this freedom of contract was inaugurated, and is to-day still usually defended, as being in the highest interests of the wage-earner himself. 'The patrimony of a poor man,' says Adam Smith, "lies in the strength and dexterity of his hands; and to hinder him from employing that strength and dexterity in what manner he thinks proper, without injury to his neighbour, is a plain violation of this most sacred property.' But the conditions of industry have somewhat changed since 1776, and the 'Billion Dollar Steel Trust,' though it does not appreciably alter the circumstances, is opening our eyes to them. We see now, what the professors of political economy have gradually become conscious of, that freedom of contract in the hiring of labour may mean something very like the compulsion of one party to serve the other, on terms nominally contractual, but virtually fixed by overwhelming superiority in strength. When the conditions of the workman's life are settled, without interference by law or trade unionism, by absolutely free contract between man and man, the workman's freedom is delusive. Where he bargains, he bargains at a hopeless disadvantage; and with regard to many of the terms most important to his health, comfort, and industrial efficiency, he cannot bargain at all. ${ }^{1}$

This conclusion will carry with it such momentous consequences, and is as yet so imperfectly realised, that it is worth while to think it over. Let us consider how the wage-contract is actually entered into. Leave out of account, to begin with, any period of bad trade, when mills

1 The whole argument on this point, with the facts on which it is based, will be found more fully set forth in our Industrial Democracy, part iii. chap. ii., 'The Higgling of the Market'; and chap. iii., 'The Economic Characteristics of Trade Unionism.' See, for a more popular presentation, The Case for the Factory Acts, edited by Mrs. Sidney Webb (London, 1902). 
are shutting down or running only short time, and armies of unemployed are looking for work. Assume that things are in equilibrium, - that there is only one place vacant, and only one 'hand' applying for it. Watch carefully the play of motives acting on the two minds, that of the 'man with the dinner pail' seeking employment, and that of the employer or foreman with a place to fill. Suppose the workman to demur to the wage offered by the employer. There is, we assume, absolutely no other spare hand in sight. To leave the vacancy unfilled may cause some inconvenience in the mill. To complete the orders in hand, some of the other men may have to work more overtime. The delivery of the goods may even have to be delayed, the year's output may be diminished, and the year's profits may be fractionally less than they would have been. But in the meantime the capitalist or his agent is not actually affected in his daily life. $\mathrm{He}$ and his family go on eating and drinking as they did before. At most, the matter is a trifling one to them. Thus, the capitalist can afford to wait until the workman returns in a humbler frame of mind. And this is just what the workman must do. What is only a trifling matter to the capitalist is to the workman his whole livelihood. Moreover, he cannot wait. Even if he stands out one day, he has thereby lost that day. His very subsistence depends on his quickly coming to an agreement. If he is obstinate, consumption of his little hoard or the sale of his furniture may delay the catastrophe. Sooner or later slow starvation forces him to come to terms. And, since success in the 'higgling of the market' is largely dependent on the relative eagerness of the parties to come to terms-conspicuously so if this eagerness cannot be concealed from the antagonist,-capitalist and workman always meet, in the absence of law or effective trade unionism, on unequal terms. Further, the capitalist knows the cards, and the workman does not. Even in the rare cases in which the absence of a single workman is of any real consequence to the employer, this is usually unknown to any 
one but himself. He, too, knows the state of the market, and can judge whether it might not even suit him better to slacken production for the moment. The isolated individual workman bargains in the dark. Add to this the fact that the workman is not trained in the art of bargaining, which is the daily business of the employer, or the constant task of an expert specially trained for the particular work of hiring men. Thus, in the bargaining between a capitalist corporation and the individual labourers whom it hires, the labourers stand to lose at every point.

So far we have been assuming that the labour market is in equilibrium, and that only one hand applies for one vacant place. But at what periods and in what trades is so perfect an equilibrium to be found? When wealthy companies are concentrating their works and shutting down unnecessary mills; when new processes or new machines are displacing labour; when industrial crises, changes of fashion, or the mere shifts and gusts of international commerce cause our production to wane, now in this branch, now in that,what freedom has the hired man? When the unemployed are crowding round the factory gates, it is plain to each one among them that, unless he can induce the foreman to choose him rather than another, his chance of subsistence for weeks to come may be irretrievably lost. Bargaining, in any genuine sense, there can be none. The foreman has but to pick his man, and name the price,- - even if he does so much as name the price. Once inside the gates, the lucky workman knows that if he grumbles at any of the surroundings, however intolerable; if he demurs to any speeding up, lengthening of the hours, or arbitrary deductions; or if he hesitates to obey any orders, however unreasonable, he condemns himself once more to the semi-starvation and misery of unemployment. The alternative to the foreman or ganger is merely to pick another labourer out of the eager crowd at the gate. The difference to the joint-stock company is nil.

But much more remains to be said. To the capitalist 
corporation the wage-contract is simply a question of so much money to be paid. To the workman it is a matter of placing, for ten or twelve hours out of every twenty-four, his whole life at the disposal of his hirer. What hours he shall work, when and where he shall get his food, the sanitary conditions of his employment, the safety of the machinery, the temperature and atmosphere to which he is subjected, the fatigue or strains that he endures, the risks of disease or accident that he incurs, - all these are involved in the workman's contract, and not in his employer's. These are matters of as vital importance to the wage-earner as are his wages. Yet about these matters he cannot, in practice, bargain at all. Imagine a weaver, before accepting employment in a cotton-mill, examining the proportion of steam in the atmosphere of the shed, testing the strength of the shuttle-guards, and criticising the soundness of the shafting belts; a mechanic prying into the security of the hoists and cranes or the safety of the lathes and steam-hammers among which he must move; a work-girl in a sweating den computing the cubic space which will be her share of the work-room, discussing the ventilation, warmth, and lighting of the place in which she will spend nearly all her working life, or examining disapprovingly the sanitary accommodation provided ; think of the man who wants a job in a white lead works testing the poisonous influence of the particular process employed, and reckoning in terms of weekly wages the exact degree of injury to his health which he is consenting to undergo. On all these matters, at any rate, we must at once give up the notion of freedom of contract. In the absence of any restraint of law, the conditions of sanitation, decency, and security from accident in the various enterprises of the United States Steel Corporation or the Standard Oil Company are really at the mercy of the rulers of these great undertakings. They decide these conditions of life for the millions of workmen whom they employ-and thus, to this extent, for the nation,-as arbitrarily (and, it is to be hoped, as humanely) as they do for their horses. 'In 
the general course of human nature,' remarked the shrewd founders of the American Constitution, 'power over a man's subsistence amounts to a power over his will.'

These features of the lot of the hired man are common to England and America, and, indeed, to every country in which capitalist industry and production are found on a large scale. We must, in intellectual honesty, recognise the fact. But this is not to say that the condition of the hired man is either good or bad, or better or worse than in bygone times. It is different from what it was when industry was carried on by the village blacksmith, different from that described by Adam Smith, different from that which Jefferson knew. The dinner pail may be fuller-as regards whole sections of the community, it can certainly be proved to be fuller,- - but there has been a change of relative status. Meanwhile, let us accept the result in the great wage-earning class as we now know it,-a community of hired men; a relatively small proportion of skilled artisans earning 'good money'; the great mass living on wages, in England of five and twenty or thirty shillings, in the United States of ten or twelve dollars, per fully employed week; while below these come the unskilled labourers and most women workers, existing, in greater or smaller numbers, under conditions of 'sweating,'-authoritatively defined as ' earnings barely sufficient to sustain existence, hours of labour such as to make the lives of the workers periods of almost ceaseless toil, sanitary conditions injurious to the health of the persons employed, and dangerous to the public.' ${ }^{2}$ Into one or another of these three categories come seventy or eighty per cent of the whole population. Such are the loyal subjects of Edward the Seventh of England; such are the free citizens of the United States. We hate to think about it, but it is so; and the advent of the Trust is going to make us realise that it is so.

1 Federalist, No. 1xxix.

2 Final Report of the Select Committee of the House of Lords on the Sweating System, I890. 
What effect will this growing consciousness of industrial subordination have upon public opinion? England developed its capitalist industry a couple of generations earlier than did the United States. Though the time for trusts and great railway combinations had not yet come, the new mills and mines which, at the end of the eighteenth century, spread over the northern and midland counties, were the - leviathans of their day, and great was the power which they wielded in the labour market. Complete 'freedom of contract' prevailed. The result, as every one knows, was the terrible 'white slavery' of the first quarter of the nineteenth century, when generation after generation of workers in the factories and coal-mines were stunted and maimed, brutalised and degraded, and hurried into early graves, by the long hours, low wages, and insanitary conditions of those halcyon days, in which, as has been said, 'it was not five per cent, or ten per cent, but thousands per cent, that made the fortunes of Lancashire.' But England grew alarmed, amid all its profit, at the rapid degeneration of whole sections of its people. By the untiring efforts of the philanthropists, Factory Act after Factory Act was passed, setting limits to freedom of contract, and substituting, for individual bargaining between man and man, definite 'common rules,' on every point deemed of prime importance to the welfare of the operatives. These common rules, securing a reasonable minimum of leisure, safety, and sanitation, applied at first only to the textile and mining industries, and are, to this day, not yet coextensive with the English wage-earning class. Nor do they apply to wages. But there grew up, after I 824 , in all the principal English industrics, strong trade unions, which enforced, by the instrument of collective bargaining, new common rules supplementing those laid down by law. The employers in each trade were numerous and divided. Differing among themselves in wealth and magnitude of business, as well as in personal character, they proved unable to present a solid front to the trade unions. The result is that, in the course of the last half century, 
some of the principal and most successful branches of English industry - notably cotton manufacture, coal-mining, ship-building, engineering, and the building trades-have come to be regulated by codes of common rules, enforced partly by law and partly by collective agreement. The rates of wages, like the hours of work and the fundamental conditions of safety and sanitation are therefore no longer at the mercy of individual capitalists. There exists in each trade a sort of minimum standard, fixed practically by general agreement among the whole body of employers on the one hand, and the whole body of workmen on the other, below which it is found impossible for any employer to descend. He may break away, but he discovers presently that it no more pays him to outrage the public opinion of his trade than to infringe the factory law. The general opinion of the community acts, in all well-organised trades, as a real though curiously intangible check upon the capitalist. Public sympathy is always on the side of a stable and highly-organised trade union defending itself against any encroachment on the common rules or reduction in rates. Great corporations like the London and North-Western Railway find themselves pulled up sharp by the peremptory interference of the Board of Trade when they are guilty of any conspicuous tyranny over their employees. Even in the late engineers' strike, where the men lost sympathy because they were believed to be resisting machinery, and the employers won all along the line, the final agreement formally recognised the right of collective bargaining and the need for common rules, while the result has been the establishment of a new tribunal of the trade to maintain these rules, - a joint tribunal, in which, for the moment, the associated employers doubtless have a larger influence than the associated workmen, but one to which every individual employer, no less than every individual workman, finds himself practically subject. This collective rule of the whole trade over every individual employer in it, as well as over every individual workman, is typical of most 
of the industries in England in which there are great employers or strong capitalist corporations. Moreover, the law, where it purports to control, really does control, even the greatest corporation. Hence neither our philanthropists nor our workmen fear the Trust. England's industrial peril lies in quite another direction.

The worst conditions of employment in the United Kingdom occur in those industries carried on by small employers, or desolated by home work, which have either escaped as yet from the ever-widening scope of the factory laws, or in which such laws are not yet effectively enforced. Here philanthropic sentiment has hitherto been evoked by the spectacle of the small master struggling to rise in the world, and unable to afford to his sweated employees either wholesome workshops, decent sanitation, or a living wage. These unfortunate workers, incapable of effective organisation, have hitherto failed to obtain the same help from public opinion or the same measure of protective legislation that Parliament concedes to the politically active cottonoperatives or coal-miners, who need it far less. Unfortunately, too, the efforts to secure effective factory laws for these workers are at present balked by the doctrinaire resistance of many of the leaders of the movement for 'women's rights.' Thus, the sweated trades, in spite of their disastrous effects on the community as a whole, are given at present a positive advantage in the competition for the world-market. The absence of any collective regulation enables the employers so to use their superiority in bargaining for the hire of their labour as to reduce its condition even below subsistence level. These trades are, in fact, parasites on the rest of the community, drawing from the more prosperous sections, in one form or another, a continual 'bounty' with which to eke out their starvation wages. Fortunately, the great staple industries of the kingdom, in which relatively good conditions prevail, gain so much in efficiency by their very regulation that they go on, notwithstanding this virtual bounty to the sweated trades, increasing in extent and prosperity year 
after year. What loses ground in England is any industry which escapes the beneficial effect of collective regulation, but which for some reason fails to get the bounty implied in industrial parasitism. The most conspicuous example is English agriculture, which is constantly falling more and more behind not only the great regulated trades such as cotton and coal, but also behind the miserably inefficient sweated trades, fed by parasitic bounty. Thus, what is most urgently needed in the United Kingdom, and what is most likely to spring from our growing consciousness of the weakness of the hired man, is not any interference with the great employers or their capitalist combinations, - which are at present the least uncontrolled of our industrial forces,- - but an extension of the strong arm of the law on behalf of the oppressed workers in the sweated trades.

Models for such action are afforded both by New Zealand and by Victoria. The time is not far distant when we shall see in London, as already in Melbourne, wage-boards for all the sweated trades, formed partly of employers and partly of wage-earners, and empowered to fix minimum rates of piece-work wages, below which it will be illegal for any employer to hire a hand. We shall, in fact, begin at the bottom of the industrial army, which suffers, not from great capitalists, but from small masters, - not from the newest methods of industrial organisation, but from the belated survival of old-fashioned ones. These wage-boards, beginning, as in Victoria, in the sweated trades, will, also as in Victoria, not rest there. New Zealand points the way. More and more nearly do we approach the stage at which the conditions of employment-wages as well as hours, sanitation as well as protection from accident, - if not fixed by authoritative decision of joint committees representing all the workmen and all the employers, are settled by an arbitrator's decree to which both parties find themselves compelled to submit. This will long be veiled in the United Kingdom, where reforms usually arrive in substance before they are called by their names. Yet English public opinion 
is already much impressed by the fact that in Victoria and in New Zealand the standard minimum conditions of employment-rates of wages as well as hours and sanitationwhich the community thinks fit to require from time to time in each particular trade, are promulgated as law, and enforced by the criminal courts. The nineteenth century in the United Kingdom has seen the extension of the factory law to sanitation and decency, hours of labour, and protection against accident, in a select set of trades. The result of our growing consciousness of the weakness of the wage-earner in his bargaining with the great capitalist employer is to bring us, at the opening of the twentieth century, to the threshold of the Legal Minimum Wage for every branch of industry. Note again Mr. Asquith's word 'prescribes.'

But the result in the United States may possibly be quite otherwise. The great capitalist corporations of the United States differ as widely from those of the United Kingdom as do the laws and the trade unions of the two countries. In England, as I have said, the great capitalist is, and feels himself to be, effectively under control. The trade unions, if inferior in strength on a fight to a finish, are in a position to offer him stubborn resistance. The law is unquestionably his master. And public opinion, not altogether on either side in the conflict, passes with great rapidity, and with irresistible force, into opposition to any serious attack on the current Standard of Life. The American capitalist corporation is, and feels itself to be, in a very different position. American philanthropy has never been stirred by the sensational evils in cotton and coal which brought about the English factory and mining laws. Legal regulation of the conditions of labour, where it exists at all, has been, and continues to be, an alien element in the American system, doubtfully constitutional and hesitatingly enforced. The indispensable administrative organisation for any real enforcement of standard conditions is nearly everywhere lacking. Nor does public opinion wish it otherwise. Throughout the whole century, and right down to our own 
day, it has been possible to retain the complacent assurance, not too obviously contradicted by fact, that the native-born American, of Anglo-Saxon or Teutonic descent, was always able to rise to a position of command, and to earn a relatively good living. There is no evidence that the concentration of industry in great capitalist corporations, or the vast accumulation of wealth in the hands of a small class, has yet had any injurious effect on wages or on the other conditions of employment. On the contrary, there is some reason to think that so far, at any rate, as foremen and skilled workers are concerned, the change in industrial organisation may be to their pecuniary advantage. In the comparatively few sections of labour in which the workmen's organisations have any real strength-these being usually the higher grades, with some approach to a monopoly of skill or high technique, - it may well suit the capitalist corporations to buy off opposition by increased wages, which could not in any case make an appreciable difference in the total cost of production. Public opinion, moreover, keenly interested in the greatest possible development of the national industry, and strongly prejudiced against the interference of 'labour unions,' will continue to operate against any effective strike. Thus, the rulers of the great capitalist corporations are, within the industrial sphere, really able to do what they like with their own. When all the employers in a single industry from California to Maine combine into a single corporation, this leviathan is, indeed, perhaps the most perfect example of freedom that the world has ever seen. In the employment of labour, especially of a low grade, such a giant corporation may impose very nearly whatever conditions it chooses. Its power of 'disciplining' any recalcitrant hand, or even a whole community, is terribly potent. It can shut down here and build up there, without let or hindrance. It can maintain whatever brutalising or deteriorating conditions of labour that it thinks profitable to itself; it can disregard with impunity all precautions against disease or accident; it can exact whatever degree of speed at work it 
pleases ; it can, in short, dispose of the lives of its myriads of workers exactly as it does of those of its horses. The workers may ' kick' ; there may be labour unions and strikes; but against such industrial omnipotence the weapons of the wage-earners are as arrows against ironclads. This will be all the more certainly the case because it will suit the leviathan, as a matter of convenience, to come to terms with the small minority of skilled and well-paid workmen, who might have stiffened the rest. This is the condition of monopolist autocracy into which every great industry in the United States 'seems fated to pass, and to pass with great rapidity. A few thousands of millionaire capitalist 'kings,' uniting the means of a few hundreds of thousands of passive stockholders, and served by perhaps an equal number of well-salaried managers, foremen, inventors, designers, chemists, engineers, and skilled mechanics, will absolutely control an army of ten or fifteen millions of practically property-less wage-labourers, largely Slavonic, Latin, or Negro in race.

Now we can hardly seriously predict, as a leading American economist is said to have done, that this freedom in autocracy will, within twenty-five years, produce an Emperor of America. But it is not difficult to see that, unless the United States learns a new lesson from the advent of the Trust, it is preparing for itself a twentieth century such as Washington would have shuddered to think of. From the purely 'business' point of view, even when reinforced by all the scientific economics of the college professor, there seems nothing to stop the triumphant progress of this capitalist autocracy. The great capitalists have no doubt thought this out, and are confident of their future profits. But what American capitalists always seem to undervalue is the influence exercised upon their profits by wide political movements. How little the Pierpont Morgans and Rockefellers of 1850 and I 856 thought about the Abolitionists! Yet the outcome of the Abolitionist agitation upset a great many capitalist schemes. Even the Bryan presidential campaign of 1896 cost the capitalists many millions in 
diminished trade, slackened output, and diverted energy. And so, the outsider ventures to predict, the advent of the Trust will lead to quite unforeseen hindrances to industrial development and quite unexpected deductions from capitalist profits, arising from the kind of civilisation which it will produce and the political reactions which it will set up. Let us, therefore, examine more closely what America has to fear from the rule of the Trusts.

Notice, to begin with, that the advent of the Trust almost necessarily implies an improvement in industrial organisation, measured, that is to say, by the diminution of the efforts and sacrifices involved in production. Just as it. was a gain to the community, from this point of view, for the myriad small masters to be merged in the relatively few capitalist employers, so it is a further gain to merge these capitalist employers into great Trusts or Corporations. The Standard Oil Company and the United States Steel Corporation represent, in fact, an improvement in industrial technique. So far as their organisations prevail, the production of commodities is carried on with less labour, less friction, less waste, than it was under the arrangements which they have superseded. There may be other disadvantages, just as there were other disadvantages when the hand-loom was superseded by the power-loom. But we must not let the drawbacks obscure the element of real progress. The rule of the great capitalist corporations secures the organisation of the work of the world in a way which enables it to be done with a smaller expenditure of labour.

But will the public be allowed to get the benefit of this industrial improvement? Is it not to be expected that the Trusts will put up prices against the consumer, and so levy a tax upon the world compared with which the exactions of Government sink into insignificance? This danger seems to me exaggerated and comparatively unimportant. It must be remembered that anything like absolute monopoly of production in the staple needs of the mass of the people is 
unknown, and practically impossible. The main products of the world are produced in too many different countries, under too many different industrial systems, standing at too varying grades of civilisation, for any absolute combination into a single hand. A Trust may, indeed, easily come to dominate a single market. But even then, so great is the potential expansion of demand for the articles of common consumption, that it will probably pay the Trust better to reduce prices than to raise them. As regards America, indeed, the remedy for any oppressive raising of prices is to abolish the customs tariff, and to call in the foreign producer. The monopolist Trust, even in countries that freely open their ports to foreign products, can no doubt make large profits. But its 'profits will represent chiefly the economies in production brought about by its own formation. The consumer will not have to pay more than the consumer of the same article in countries not subject to the Trust, except by the amount of the freight, and probably, as we shall see, not even by so much as that. Hence we may expect the increasing dominance of the Trust to make for the abolition of protective duties. It is, indeed, not the consumer, as consumer, who need particularly fear the Trusts. If, however, this conclusion proves erroneous, the consumer, as citizen, has another remedy, to which we shall refer at the end of this Introduction.

The competent, 'pushful,' native-born American will get on all right under this capitalist autocracy. He will, indeed, have to give up the chance of becoming his own master, and, practically, that of 'making a pile.' But what will be virtually the civil service of industry, the great salaried hierarchy of the Trusts, will offer a safer and, on the average, a better paid career for industrial talent than the old chances of the market. Every man of skill and energy, competence and 'go,' will be wanted in the gigantic organisation of the new industry. Brains will be at a premium. From the skilled mechanic right up to the highest engineering genius, from the competent foreman up to the brightest railway 
organiser, from the merely practised chemist up to the heaven-born inventor or designer,-all will find, not merely employment, but scope for their whole talent; not merely remuneration, but salaries such as the world has seldom seen. And in serving their employers they will be at least as directly serving the community as they are at present.

It is when we come to the great mass of wage-earners - the ten or fifteen millions of day-labourers and ordinary artisans - that we see the really grave consequences of industrial autocracy. These men, with their wives and families, must necessarily constitute the great bulk of the population, the 'common lump of men.' It is in their lives that the civilisation of a nation consists, and it is by their condition that it will be judged. And, though the great ones never believe it, it is upon the status, the culture, the upward progress of these ordinary men that the prosperity of the nation, and even the profits of the capitalists, ultimately depend. What is likely to be the Standard of Life of the ordinary labourer or artisan under the great industrial corporations of the United States?

Now one thing is definitely proved, both by economic science and business experience. If the wages of common labour are left to 'supply and demand,' and are not interfered with by factory law or effective trade unionism, we shall witness no improvement in the present conditions of life of the Pennsylvania miner, the Chicago sweat-shop hand, the day-labourer on the railroad, or the girl seamstresses sewing for dear life in New York tenement garrets. On the contrary, we shall see these conditions of life generalised over the whole range of common labour, male or female. We shall find wages everywhere forced down, for the ordinary, common skilled worker, to their 'natural level'- that is, to the barest subsistence of the human animal from day to day. With this state of things will necessarily go the corresponding life, such as we see it already in the Pittsburg or Chicago slum. It is, however, needless to amplify the picture. To what awful depths 
of misery and demoralisation, brutality and degradation, humanity can, under 'perfect freedom,' descend, we are scarcely yet in a position to say. Is this to be the contribution to economics, in the twentieth century, of the country of Jefferson and Washington?

Fortunately for the world, the United States is not likely to make this experiment. The millions of common labourers, however poor and degraded they may be, or may become, are yet citizens and voters,-are, moreover, the inheritors, even if of alien race, of glorious traditions of manhood and freedom. That uncontrolled personal power which several centuries of struggle have displaced from the throne, the castle, and the altar, is not likely to be allowed to rule in the farm, the factory, and the mine. As yet, the American citizen still believes himself to be free, and sees not the industrial subjection into which he is rapidly passing. But it is not to be supposed that he will witness unmoved the successive failures of trade unions and strikes, the general reductions in wages which will mark the first spell of bad trade, the manifold dismissals and 'shuttings down,' the progressive degradation of his class. He will take up every wild dream and every mad panacea. He will be tricked and outvoted again and again; but if so, the result will be a 'class war' more terrible than any the world has seen, and one in which, though the ultimate victory will be with the common people, American civilisation may go back several generations.

Yet America ought to avoid this catastrophe. The experiment has already been tried, and the remedy is known. If the people of the United States will but do that most difficult of all things-learn by the experience of other nations, - they may get out of the Trusts all the advantages which these offer, without suffering the terrible calamity in which they unwittingly threaten to oxerwhelm American civilisation. The remedy lies in what we, in our Industrial Democracy, have ventured to call the 'Policy of the National Minimum.'. We must give up the idea of 
individual freedom of competition, which the combinations of capital have proved to be illusory, and take up, instead, the higher freedom of collective life. We must get back as. a community what we have lost as individuals.

The Policy of the National Minimum translates itself into four main branches of legislative and executive activity. There will have to be a national minimum of wages. The Trusts, or the other employers, will be- under no legal obligation to employ any person whatsoever. But if they do employ him or her, it will be a condition of every contract, not to be waived or ignored, that its terms shall not be such as will impair the efficiency of the citizen or diminish the vitality of the race. To engage labour at wages insufficient to repair the waste of tissue caused by the employment is demonstrably to injure the community as a whole, and will be prosecuted as such in the criminal courts. Those whose labour is not worth the national minimum - the aged, the crippled, and the blind; the mentally or morally deficient; the epileptic; and the chronically feckless and feeble-minded-will be maintained by the community, as indeed they are now. But of all the ways of maintaining those unable to earn a full livelihood, by far the most costly and injurious is to allow them to compete in the labour market, and thus to drag down by their very infirmity those who are whole. There are still people, of course, who simply cannot imagine how a legal minimum wage could possibly be enforced, just as there were, sixty years ago, economists who demonstrated the impossibility of factory laws. We have dealt fully with their difficulties and objections in our Industrial Democracy. As a matter of fact, the legal minimum wage can be seen in force to-day in Victoria and New Zealand, South Australia and New South Wales.

There will be a national minimum of leisure and recreation secured by law to every citizen. It will be an implied condition of every contract of employment, rigidly enforced by law, that it shall leave untouched sixteen hours 
out of each twenty-four for needful sleep, recreation, exercise of mind or body, and the duties of citizenship and family life. Any attempt by man or woman to sell for wages any part of the sixteen sacred hours will be blamed as virtual embezzlement, since this part of the twenty-four hours day must be regarded as necessarily reserved for the purpose of maintaining unimpaired the efficiency of the race. Any employer purchasing them, or allowing them to be spent in his mill or mine, will be prosecuted and punished, as if he had incited to embezzlement or had received stolen goods.

There will be a national minimum of sanitation, enforced not merely on land or house owners or occupiers, but also on local governing authorities. The nation will find it preposterous that any city, merely out of stupidity or incapacity or parsimony, should foster disease, or bring up its quota of citizens in a condition of impaired vitality. The power of the community as a whole, will, somehow or other, be brought to bear upon every backward district, compelling it to lay on pure water, to improve its drainage, and to take such action, even by municipal building if need be, that no family in the land shall have less than 'three rooms and a scullery,' as the minimum required for health and decency. Along with this must go the adequate provision of medical attendance, skilled nursing, and hospital accommodation for the sick. Within a generation of the adoption of such a policy, the death-rate and sickness experience would show a reduction of one-third of what is at present endured as if it were the decree of Providence.

There will be a national minimum of education-not merely in the provision of schools, but in genuinely compulsory attendance at them. Besides schools and colleges of every grade, there will have to be an adequate 'scholarship ladder,' securing maintenance as well as free tuition, right up to the post-graduate course, for every scholar proving himself or herself fitted for anything beyond common schooling. And this provision will be enforced by the national power upon local school authorities as well 
as upon parents and employers. What right has any part of the community to allow any part of its quota of citizens to be reared in ignorance or to suffer even one potential genius to; be lost to the community? The next few years will see not only a great improvement in common schooling but also the doubling or trebling of our expenditure on higher education.

Only by the enforcement of some such national minimum of subsistence, leisure, sanitation, and education will modern industrial communities escape degeneration and decay. Where life is abandoned to unfettered competition, what is known as 'Gresham's Law' applies-the bad drives out the good. To prevent this evil result, is, as both Europe and America are discovering in the twentieth century, the main function of government. To enforce the national minimum will, moreover, not interfere either with the profits or with the freedom of development of the exceptional man, while it will enormously increase the prosperity of the community. Nor does it abolish competition. What it does is to transfer the competitive pressure from the actual means of subsistence of the masses (where it works little but harm), to the intellect of every one who has any, in the degree that he has it (where it sharpens the wits).

This remedy for the dangers of modern industrialismthe Policy of the National Minimum-involves, it will be seen, a great extension of government activity, a great advance in the efficiency of both legislative and executive machinery, and no little change in constitutional forms. All this will be difficult enough. Moreover, the consumer, as consumer, remains unprotected. Hence, whilst the mere enforcement of the national minimum adequately solves the problem presented by the sweated trades, it may be found not completely to answer for those at the other end of the scale, in which great Trusts have been organised. It may, therefore, well be easier, in one industry after another, to take over the Trust into direct public ownership, as one nation or another has already done in the case of railways, 
telegraphs, telephones, ocean cables, steamboat lines, water, gas, electric and hydraulic plants, and what not. One way or another the people must collectively control the industry by which they live, or, for large masses of the community, every hope of genuine freedom and civilisation will disappear.

July, 1902. 


\section{PREFACE}

WE have collected in the present volume some essays and studies written during the last ten years. Each chapter deals with a separate subject, and is complete in itself. But the different chapters are not without bearing upon each other; and thcir common standpoint and identical assumptions may, perhaps, be considered to give the book a certain unity which it would otherwise lack.

We have corrected a few errors; brought the statistics up to date, and supplied additional footnotes and references. Otherwise, the chapters stand practically as they were written, with the characteristic imperfections of essays and studies done in the intervals of more sustained work. Some of the ideas here incidentally expressed will be found more elaborately treated in our History of Trade Unionism and Industrial Democracy. On the other hand, some of the points incidentally alluded to in those works are more fully dealt with in these essays.

Certain of the chapters have appeared, in part, in the Nineteenth Century, Contemporary Review, Economic Journal and Quarterly Journal of Economics, and we are indebted to the editors for permission to reproduce them. The essay upon 
xxxiv

Problems of Modern Industry

'The Jews in East London' was contributed to Mr. Charles Booth's Life and Labour of the People, and our thanks are due to Mr. Booth for his consent to its inclusion in this volume.

\section{SIDNEY \& BEATRICE WEBB.}

4I Grosvenor Road, Westminster.

March 1898 . 


\section{CONTENTS}

Preface to the Issue of I920, , , v

InTRODUCTION TO THE I902 EDITION , , , 。 ix

Preface (OF I898) . . , , , xxxiii

\section{CHAPTER I}

The Diary of an Investigator. By B. W. . . I I

\section{CHAPTER II}

The Jews of East London. By B. W. . . . 20

CHAPTER III

Women's Wages. By S. W. . . . . . . 46

CHAPTER IV

Women and the FaCtory Acts. By, B. W. . . 82

CHAPTER V

The Regulation of the Hours of Labour. By S. W. 102

CHAPTER VI

How to do away with the Sweating System. By B. W. $\quad$ I 39

CHAPTER VII

The Reform of the Poor Law. By S. W. . . 156 
xxxvi Problems of Modern Industry

CHAPTER VIII

The Relationship Between Co-operation and Trade PAGE UNIONISM. BY B. W. . . . . . . . 192

\section{CHAPTER IX}

The National Dividend and its Distribution. By S. W. 209

\section{CHAPTER X}

The Difficulties of Individualism. By S. W.

\section{CHAPTER XI}

Socialism: True and False. By S. W. 


\section{CHAPTER I}

\section{THE DIARY OF AN INVESTIGATOR ${ }^{1}$}

IT is mid-day. The sun's rays beat fiercely on the crowded alleys of the Jewish settlement: the air is moist from the heavy rains. An unsavoury steam rises from the downtrodden slime of the East End streets and mixes with the stronger odours of the fried fish, the decomposing vegetables, and the second-hand meat, which assert their presence to the eyes and nostrils of the passers-by.

For a brief interval the 'whirr' of the sewing-machines and the muffled sound of the presser's iron have ceased. Machinists and pressers, well-clothed and decorated with heavy watch-chains; Jewish girls with flashy hats, full figures, and large bustles; furtive-eyed Polish immigrants with their pallid faces and crouching forms; and here and there poverty-stricken Christian women-all alike hurry to and from the mid-day meal; while the labour-masters, with their wives and daughters, sit or lounge round about the house-door, and exchange notes on the incompetency of

1 Nineteenth Century, September 1888. Owing to the anonymity of East End life, and its ignorance of magazines and books, it was possible, by merely changing the names of streets and firms, to publish these few pages trom my private diary without risk of annoyance to the persons concerned. Such publication of the investigator's private notes is seldom practicable. But in spite of this inability to 'make copy,' the student of any piece of social organisation will find it adds to the fulness and reality of his scientific work, if he supplements his collections of technical facts and his statistical tables, by detailed descriptions, for his own private use, of typical scenes and characters. 
seasun hands the low price of work, the blackmail of shop foremen ; or else discuss the more agreeable topic of the last 'deal' in Petticoat Lane and the last venture on racehorses.

Jostled on and off the pavement, I wander on and on, seeking work. Hour after hour I have'paced the highways and byways of the London Ghetto. No bills up except for a 'good tailoress,' and at these places I dare not apply, for I feel myself an impostor, and as yet my conscience and my fingers are equally unhardened. Each step I take I am more faint-hearted and more weary in body and limb. At last, in sheer despair, I summon up my courage. In a window the usual bill, but seated on the doorstep a fat cheerful-looking daughter of Israel, who seems to invite application.

'Do you want a plain 'and?' say I, aping ineffectually a workwoman's manner and accent, and attaining only supreme awkwardness.

The Jewess glances quickly, first at my buttonless boots, then at my short but already bedraggled skirt, upwards along the straight line of my ill-fitting coat, to the tumbled black bonnet which sits ill at ease over an unkempt twist of hair.

'No,' is the curt reply.

' I can do all except buttonholes,' I insist in a more natural tone.

She looks at my face and hesitates. 'Where have you worked?'

'In the country;' I answer vaguely.

She turns her head slowly towards the passage of the house. 'Rebecca, do you want a hand?'

'Suited an hour ago,' shouts back Rebecca.

'There, there, you see,' remarks the Jewess in a deprecating and kindly voice as her head sinks into the circles of fat surrounding it. 'You will find plenty of bills in the next street; no fear of a decent young person, as knows her work, staying out o' door this time of year'; and then, 
turning to the woman by her side: 'It's rare tho' to find one as does. In these last three days, if we've sat down one, we've sat a dozen to the table, and not a woman amongst them as knows how to baste out a coat fit for the machine.'

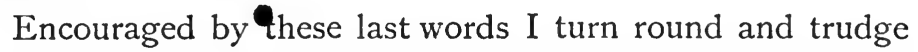
on. I ask at every house with a bill up, but always the same scrutinising glance at my clothes and the fatal words, 'We are suited!'

Is it because it is the middle of the week, or because they think I'm not genuine? think I. And at the next shop window I look nervously at my reflection, and am startled at my utterly forlorn appearance-destitute enough to be 'sweated' by any master.

'Sure, there's not much on 'er back to take to the h'old uncle,' remarks an Irish servant to her mistress, as I turn away from the last house advertising for a 'good tailoress.'

I feel horribly sick and ill; and I am so painfully conscious of my old clothes that I dare not ask for refreshment at an eating-house or even at a public. Any way, I will have air, so I drag one foot after another into the Hackney thoroughfare. Straight in front of me, in a retail slop-shop of the lowest description, I see a large placard: 'Trouser and Vest Hands Wanted Immediately.' In another moment I am within a large workroom crowded with women and girls as ill-clothed as myself. At the head of a long table, examining finished garments, stands a hard-featured, shrewd-looking Jewess, in a stamped cotton velvet and with a gold-rimmed eyeglass.

'Do you want trouser hands?'

'Yes we do-indoor.'

'I'm a trouser finisher.'

The Jewess examines me from head to foot. My standard of dress suits her. 'Call at eight o'clock to-morrow morning.' And she turns from me to look over a pair of trousers handed up the table.

'What price do you pay?' say I with firmness. 
'Why, according to the work done, to be sure. All prices,' she answers laconically.

'Then to-morrow at eight.' And I leave the shop hurriedly to escape that hard gaze of my future mistress. Again in the open street: the dazed-headiness, the dragging back-ache, and the sore feet-all the physical ills and moral depressions of the out o' work-seem suddenly swept away. At length, after this weary pilgrimage, I have secured work. The cool evening breęze, the picturesque life and stirring activity of the broad highway, even the sounds and sights of East London, add to my feeling of intense exhilaration. Only one drawback to perfect content: Can I 'finish' trousers?

At a few minutes past eight the following morning I am standing in front of 'MOSES AND SON. CHEAP CLOTHING.' In the window two shop-boys are arranging the show garments: coats and vests (sold together), i $7 \mathrm{~s}$. to 22s.; trousers from 4s. 6 d. up to I Is. 6 d.

'Coats evidently made out: I wonder where and at what price?' ponders the investigator as the work-girl loiters at the door.

'You'd better come in,' says the friendly voice of a fellow-worker as she brushes past me. 'You're a newcomer ; the missus will expect you to be there sharp.'

I follow her into the retail shop, and thence through a roughly-made wooden door. The workroom is long and irregularly shaped, somewhat low and dark near the entrance, but expanding into a lofty skylight at the further end. The walls are lined with match-boarding; in a prominent place, framed and under glass, hang the Factory and Workshop Regulations. Close by the door, and well within reach of the gas-stove (used for heating irons), two small but high tables serve the pressers: a long low plank-table, furnished with a wooden rail for the feet, forms on either side of it, chairs top and bottom, runs lengthways for the trouser finishers; a high table for the basters; and, directly under the skylight, two other tables for machinists and vest hands 
complete the furniture of the room. Through an open door, at the extreme end of the workshop, you can see the private kitchen of the Moses family; and beyond, in a very limited backyard, an outhouse, and, near to it, a tap and sink for the use of all the inmates of the establishment.

Some thirty women and girls are crowding in. The first arrivals hang bonnets and shawls on the scanty supply of nails jotted here and there along the wooden partition separating the front shop from the workroom; the later comers shed their outdoor garments in various corners. There is a general Babel of voices as each 'hand' settles down in front of the bundle of work and the old tobacco or candle-box that holds the cottons, twist, gimp, needles, thimble, and scissors belonging to her. They are all English or Irish women, with the exception of some half-dozen welldressed 'young ladies' (daughters of the house), one of whom acts as forewoman, while the others are already at work on the vests. The 'missus' is still at breakfast. A few minutes after the half hour the two pressers (English lads, and the only men employed) saunter lazily into the room, light up the gas-jet, and prepare the irons.

The forewoman calls for a pair of trousers, already machined, and hands them to me. I turn them over and over, puzzled to know where to begin. The work is quite different from that of the bespoke shop, at which I was trained-much coarser and not so well arranged. Besides, I have no cotton, thread, twist, or gimp. The woman next me explains: 'You'll 'ave to bring trimmings; we h'ain't supplied with them things y'ere; but I'll lend you some, jist to set' off with.'

'What ought I to buy?' I ask, feeling rather helpless.

At this moment the 'missus' sweeps into the room. She is a big woman, enormously developed in the hips and thighs; she has strongly marked Jewish features, and, I see now, she is blind of one eye. The sardonic and enigmatical expression of her countenance puzzles me with its far-off associations, until I remember the caricatures, sold in City 
shops for portraits, of the great Disraeli. Her hair is crisp and oily-once jet-black, now, in places, gray-it twists itself in scanty locks over her forehead. The same stamped cotton velvet, of a large flowery pattern, that she wore yesterday; a heavy watch-chain, plentiful supply of rings, and a spotlessly clean apron.

'Good-morning to you,' she says graciously to the whole assembly as she walks round our table towards my seat. 'Sarah, have you given this young person some work?'

'Yes,' replies Sarah ; 'fourpence halfpenny's.'

'I have not got any trimmings. I did not know that I had to supply them. Where I worked before they were given,' I ejaculate humbly.

'That's easily managed; the shop's just round the corner- Or, Sarah,' she calls across the table, 'you're going out-just get the young person her trimmings. The lady next you will tell you what you want,' she adds in a lower tone, bending over between us.

The 'lady' next me is already my friend. She is a neat and respectable married woman with a look of conscious superiority to her surroundings. Like all the trouser hands she is paid by the piece; but in spite of this she is ready to give me up time in explaining how I am to set about my work.

'You'll feel a bit strange the first day. 'Ave you been long out o' work ?'

'Yes,' I answer abruptly.

'Ah! that accounts for you're being a bit awkward-like. One's fingers feel like so many thumbs after a slack time.'

And certainly mine do. I feel nervous, and very much on trial. The growing heat of the room, the form so crowded that one must sit sideways to secure even a limited freedom for one's elbows; the general strangeness of my position-all these circumstances unite to incapacitate a true hater of needlework for even the roughest of sewing. However, happily for me no one pays me much attention. As the morning wears on, the noise increases. The two 
pressers have worked up their spirits, and a lively exchange of chaff and bad language is thrown from the two lads at the pressing (immediately behind us) to the girls round our table. Offers of kisses, sharp despatches to the devil and his abode, a constant and meaningless use of the inevitable adjective, form the staple of the conversation between the pressers and the younger hands; while the elder women whisper scandal and news in each other's ears. From the further end of the room catches of music-hall songs break into the monotonous whirr of the sewing-machine. The somewhat crude and unrhythmical chorus-

Why should not the girls have freedom now and then? And if a girl likes a man, why should she not propose? Why should the little girls always be led by the nose?

seems the favourite refrain, and, judging from the gusto with which it is repeated, expresses the dominant sentiment of the work-girls. Now and again the mistress shouts out, 'Sing in time, girls; I don't mind you singing, but sing in time.' There is a free giving and taking of each other's trimmings, a kindly and general supervision of each other's work-altogether a hearty geniality of a rough sort. The enigmatical and sardonic-looking Jewess sits at the upper end of our table, scans the finished garment through her gold-rimmed eyeglass, encourages or scolds as befits the case ; or, screwing up her blind eye, joins in the chatter and broad-witted talk of the work-women immediately surrounding her.

'The missus 'as sixteen children,' remarks my friend Mrs. Long confidentially - 'h'eight by Mr. Moses, and h'eight by the master she buried years ago, All them girls at the bottom table ar' 'er daughters.' tone.

'They are a nice-looking set,' say $\mathrm{I}$, in a complimentary

'Yes, it's a pity some of the girls in the shop h'ain't like them,' mutters my respectable friend. 'They're an awful bad lot, some of them. Why, bless you, that young person 
as is laughing and joking with the pressers jist be'ind us 'and here follow horrible details of the domestic vice and unnatural crime which disgrace the so-called 'Christian' life of East London.

'Eh, eh!' joins in the woman next her, with a satisfied sniff at the scandal (a regular woman of the slums, with nose and skin patched by drink), 'it's h'ill thinking of what you may 'ave to touch in these sort of places.'

'Well to be sure,' rejoins Mrs. Long, nettled both by the tone of superiority and by the unwarranted interruption of her disreputable neighbour. 'I've worked at this same place for h'eight years and never yet 'ave I 'ad words with any one. There's reg'ler work the week round, and reg'ler pay on a Saturday; and y're money kept for you, if you 'appen to be a-cleaning. There's no need to mix y'rself up with them whose look you don't like,' she adds, with just a perceptible edging away from the slum woman, as if to emphasise her words - ' there's some of all sorts y'ere.'

'H'I'm one of that sort,' blusters the woman of the slums, 'that h'answers a person back when they call me bl-y names. H'I'll give the last word to no one.'

'I don't choose to 'old conversation wi' the like of they,' says Mrs. Long, pursing up her thin lips as if to end this undesired intercourse: 'it h'ain't as if $I$ 'ad to work for my living. My 'usband's in reg'ler work; it's only for the hextras like that I work, and jist for them times, per'aps. a month the 'ole year through, that the building trade's slack.'

This effectually silences the woman of the slums. Her husband, alas! comes home drunk every night and spends the irregularly earned pence lounging about the publics (so I am afterwards informed by Mrs. Long). She has an illfavoured daughter by her side, with a black eye and a swollen face, with whom she exchanges work and bad language and shares greasy victuals.

' One o'clock,' shouts a shrill boy's voice.

'Stop work,' orders the mistress. 
'I wish I might finish this bit,' I say pathetically to my friend, painfully conscious of the shortcoming in the quantity, if not in the quality of my work.

'You mustn't ; it's the dinner hour.'

The pressers are already off, the mistress and her daughters retire into the kitchen: the greater number of women and girls turn out into the street, while one or two pull baskets from under the table, spread out before them, on dirty newspapers, cracked mugs, bits of bread and butter, cold sausage or salt fish; and lift, from off the gas-stove, the tin teapot wherein their drink has been stewing since the early morning. Heartily thankful for a breath of fresh air and a change from my cramped posture, I wander up and down the open street, and end my 'dinner hour' by turning into a clean shop for a bun and a fresh cup of tea. Back again at two.

'You must work sharper than this,' remarks the mistress, who is inspecting my work. I colour up and tremble perceptibly as I meet the scrutinising gaze of the hardfeatured Jewess. She looks into my eyes with a comically puzzled expression, and adds in a gentler voice: You must work a little quicker for your own sake. We've had worse buttonholes than these, but it don't look as if you'd been 'customed to much work.'

But now the drama of the day begins. The two pressers saunter in ten minutes after the hour. This brings down upon them the ire of the Jewess. They, however, seem masters of the situation, for they answer her back in far choicer language than that in which they were addressed -language which I fear (even in a private diary) I could hardly reproduce; they assert their right to come when they choose; they declare that if they want a day off they 'will see her to the devil and take it'; and lastly, as a climax to all insults, they threaten her with the 'factory man,' and taunt her with gambling away on racehorses the money she 'sweats' out of them.

At these last words the enigmatical and sardonic ex- 
pression of the Jewess changes into one of outbursting rage. All resemblance of the City caricatures of that great passionless spirit vanishes. The deep furrows extending from just above the nostril to the corner of the mouthlines which must surely express some race experience of the children of Israel-open out into one universal bubble of human fury. A perfect volley of oaths fly in quick succession between the principal combatants; while woman after woman joins in the fray, taking the missus's side against the pressers. The woman of the slums actually rises in her seat and prepares to use her fists; while her daughter seizes the opportunity to empty the small bottle of brandy hidden under her mother's trimmings. Mrs. Long purses up her thin lips still more tightly, and looks down steadily at her work. At this critical point-enter the master.

Mr. Moses is a corpulent, well-dressed English Jew. His face is heavy and sensual, his eyes sheepish, his reputation among his wife's 'hands' none of the best. At this moment, his one desire is to keep the Queen's peace in his establishment. I suspect, also, from the sleepy viciousness of his expression, that he himself suffers occasionally from the missus's forcible tongue; and with this bevy of women shouting on all sides he feels the masculine side of the question. Any way, he is inclined to take a strictly impartial view of the row. 'Sit down, Mrs. Jones,' he shouts to the woman of the slums-' sit you down, or you and that daughter of yours leave the shop this very instant. Now, lads, just you be quiet; go on with your work and don't speak to my wife.' And then, turning to his wife, in a lower tone-' Why won't you leave them alone and not answer them?' and the rest of his speech we cannot hear; but, judging from the tone and the look, it takes the form of deprecating expostulation. I catch the words 'push of work' and 'season hands.'

'Why, if you were only a bit of a man,' cries the mistress, raising her voice so that all may hear, 'you'd 
throw these two bl-y rascals out. I'd throw them out at any price, if I were a woman's husband. The idea of saying how I spend my money - what's that to him? And that Jo says he'll call the factory man in. $\mathrm{He}$ may call the devil in (and he's welcome) - the only person as he'll notice will be himself. The idea of him saying that I spend my money on horses; as if I couldn't spend money on anything I like. As if you wouldn't give me money as I earn, when I asks you, Mr. Moses,' gasps the Jewess, as she looks threateningly at her partner, 'and never ask where it goes to.' The betting on horses is evidently a sore point.

'It isn't their business what you do with your money;' rejoins the master soothingly. 'But just let them alone, and tell those girls to be quiet. It's more than half the girls' fault-they're always at the fellows,' he adds, anxious to shift the blame into a safe quarter.

The storm lulls, and Mr. Moses returns into the front shop. But the anger of the Jewess is not yet exhausted. A stray word, and the quick firing of abusive language between the mistress and the pressers begins afresh; though this time the women, awed by the master's interference, are silent. The tall, weak-looking, young man, Jo by name, shouts the longest and loudest; but, as Mrs. Long whispers to me, without raising her eyes from her work, 'It's 'Arry as makes the bullets-jist listen to 'im-but it's Jo as fires 'em !'

At last it subsides. Women (outdoor hands) troop in with bundles of finished trousers. The bubbling rage of the injured woman yields to the keen-eyed supervision of the profit-making Jewess. 'I'd have nothing but indoor hands. if $I$ knew where to find them and had a room to put them into,' she mutters to Esther as she turns over garment after garment. 'Just look at this work, it's all soap! Call again on Monday morning, Mrs. Smith. But mind it is Monday, and not Tuesday morning. You understand English, don't you ?-Monday morning.'

A small boy creeps into the shop laden with unfinished 
work. 'What d'you say to this, Sarah? Mrs. Hall sends word she was washing on Monday, cleaning on Tuesday, and I suppose playing the devil on Wednesday, for here's Thursday, with shop day to-morrow, and the work's untouched. Now, girls, be quick with your work,' continues the mistress as she throws the bundle on to our table-' all this to be done extra before Friday. Perkins won't wait for no one!'

'The name of a wholesale shipping firm; so she works for export as well as for retail and pays same price for both,' inwardly notes the investigator as she glances at the shoddy garments. (The work-girl meanwhile pushes her needle into her thumb-nail, and in her agony digs her elbow into her neighbour's half-turned back, which causes a cannonade all round the table.)

'Law! how awkward she still be,' growls the woman of the slums, anxious to pick a quarrel, and vent her unspent wrath.

At length tea-time breaks the working-day. Pence have already been collected for the common can of milk; innumerable teapots are lifted off the gas-stove, small parcels of bread and butter, with a relish or a sweet, are everywhere unrolled. My neighbours, on either side, offer me tea, which I resolutely refuse. The mistress sips her cup at the head of the table. The obnoxious pressers have left for the half-hour. Her feelings break out-

'Pay them 5 s. a day to abuse you! As if I couldn't spend my money on what I like; and as if Mr. Moses would ever ask-I'd like to see him ask me-how the money'd gone!'

All the women sympathise with her, and vie with each other in abusing the absent pressers.

'It's h'awful, their language,' cries the slum woman; 'if I were the missus, I'd give the bl-y scoundrels tit for tat. Whativer's the use of bein' a missus if you've got to 'old in y're tongue?'

'As for the factory man,' continues the irate Jewess, 
turning to the other sore point, "just fancy threatening me with him! Why they ar'n't fit to work in a respectable shop; they're d-d spies. I'd throw them out, if it cost me £roo. And if Mr. Moses were half a man, he'd do it tỏo.'

At the word spy, I feel rather hot; but conscious of the innocence of my object, I remark, 'You have nothing to fear from the factory inspector; you keep the regulations exactly.'

'I don't deny', she answers quite frankly, 'that if we're pressed for work I turn the girls upstairs; but it isn't once in three months I do it; and it all tells for their good.'

Two hours afterwards, and I have finished my second pair. 'This won't do,' she says as she looks over both pairs together. 'Here, take and undo the band of that one; I'll set this one to rights. Better have respectable persons, who know little, to work here, than blaguards who know a lot-and a deal too much,' she mutters, smarting over the taunts of the 'factory man' and the money laid on horses. voice.

'Eight o'clock by the Brewery clock,' cries the shrill

'Ten minutes to,' shouts the missus, looking at her watch. 'However, it ain't worth while breaking the law for a few minutes. Stop work.'

This is most welcome to me. The heat since the gas has been lit is terrific, my fingers are horribly sore, and my back aches as if it would break. The women bundle up their work; one or two take it home. Every one leaves her trimmings on the table, with scissors and thimble. Outside, the freshness of the evening air, the sensation of free movement, and rest to the weary eyes and fingers constitute the keenest physical enjoyment I have ever yet experienced.

Friday morning, and I am hopelessly tired. Jammed between my two neighbours, with the garment of hard 
shoddy stuff on my knee, and with the whole day's work before me, I feel on the brink of deep disgrace as a workgirl. I am 'shaky-like all over,' my fingers, worn in places into holes, refuse to push the thick needle through the objectionable substance; damp hands (the more I rub them in my apron the damper they become) stretch the thin linings out of place; my whole energy is riveted on my work, with the discouraging result that it becomes worse and worse. Mrs. Long works silently by my side at high pressure to bring a pair of 'ordered' trousers in to time. And she begins to scent dismissal.

'I keeps myself to myself,' she told me yesterday. 'Down y're they're all a-going down 'ill; except them Jews as is going hup.' And to-day she applies her theory strictly, and is unwilling to 'mix herself up' with even a respectable failure. So I bungle on without help until I have finished after a fashion.

'This will never do,' angrily remarks the mistress. And then, perceiving the culprit by her side, she adds sternly: 'This won't do-this work won't suit me; you want to go and learn somewhere first. This will never do-this won't suit me,' she repeats slowly as she pulls the work to pieces. She dismisses me from her sight with a wave of her eyeglass, as if to say, 'It's no good answering me back again.'

Without a word I arrange my trimmings ready to depart if the missus persists.

Is it over-fatigue, or is it the perfect realisation of my position as a disgraced work-girl? An ominous lump rises in my throat, and my eyes fill with tears. There is a dead silence. The younger hands look up from their work sympathetically; Mrs. Long, with her head down, stitches on steadily; the woman of the slums gazes on me with bleared expression of mingled stupor and pity; fumbles underneath her work on the table and pushes something towards me. I hear the rattle of the brandy-bottle against the scissors as I see the old tobacco-box that holds her trimmings advancing towards me. Meanwhile the Jewess has screwed up her left 
eye and is looking at me through her eyeglass. The deep furrows of inherited experience again relax in favour of personal feeling. But this time it is human kindness instead of human fury. She beckons to me. In a second I am by her side.

'I'll see what I can do with you. If you like to stay and work on threepence-halfpennies, the same as I give to outdoor hands, you can take better work when you're fit for it. I'm sure I don't want to be hard on any decent young person as is trying to earn her living in a respectable way. There ain't so many respectable persons in the world that we can afford to starve 'em,' the Jewess adds, casting an angry glance at the pressers. 'Sarah, give her a pair of threepence-halfpennies. I'll alter these for you. You sit between these two young ladies and they'll show you. You must help one another,' she says to the girls as they make room for me; 'tho' of course they all come here to make their own living; you can't expect them to teach you for ever.'

The girl who takes me under her especial charge is a respectably dressed and delicate-looking young woman, with none of the rowdy slovenliness or tarnished finery of the typical Gentile girl of East London. Slightly made, with a pale, weary face, she looks at least thirty (she tells me she is only just nineteen); she stitches silently, and seems hardly conscious of the boisterous life of her fellow-workers; but instead of Mrs. Long's air of ever-present superiority, her form, face, manner, denote physical depression, lit up now and again by the dreamy consciousness of another world beyond the East End workroom.

'You'll soon learn,' she says kindly ; 'you must watch me fix this, and then you can do the next yourself.'

Directed and encouraged by her kindness, I work on, in a calmer frame of mind, listening to the conversation of my neighbours. Among the younger hands who sit at this end of the table it chiefly concerns the attraction of the rival music-halls, or the still more important question of the 
presents and attentions of their different 'blokes.' For monotonous work and bad food have not depressed the physical energies of these young women. With warm hearts, with overflowing good nature, with intellects keenly alive to the varied sights of East London, these genuine daughters of the people brim over with the frank enjoyment of low life. During the day their fingers and eyes are fully occupied; in the evenings, on holidays, in the slack season, their thoughts rush out and gather in the multitudinous excitements of the East End streets; while their feelings unburden themselves in the pleasure of promiscuous lovemaking. You cannot accuse them of immorality, for they have no consciousness of $\sin$. The veneer of morality, the hidden but secretly self-conscious vice of that little set that styles itself 'London society' (in the city of millions!) are unknown to them. They live in the Garden of Eden of uncivilised life; as yet they have not tasted the forbidden fruit of the Tree of the Knowledge of Good and Evil, and the heaven and hell of an awakened conscience are alike undreamt of. There is only one Fall possible to them-drink, leading slowly but inevitably to the drunkard's death.

'I say, Milly', shouts one to the other, 'you tell that bl-y brother of yours that I waits 'alf an 'our for 'im houtside the Paragon last night. I'll be blessed before I serves as 'is Round the Corner ${ }^{1}$ ag'in. 'Owever, at last, I says to myself, "a watched kittle niver biles," so I walks in by myself. The dressin' there is grand,' she adds enthusiastically.

'Eh! but you sh'd see the piece they're running at the Standard!' rejoins Milly. 'Jim's promised to take me up to one of them grand places up West next Saturday. Will you come along? I'll get Tom to come. You'll want to be a making of it up by that time. Tom's in reg'lar work and a rare catch h'as a sweet'eart,' laughs the sister of the faithless swain.

'It's too much trouble to go up West,' answers the girl,

1 The East End term for the lady you take to the theatre or the music-hall. 
anxious to prove her indifference to Tom's attentions. 'I don't care to turn h'out 'fore 'alf-past nine. It takes a full hour to clean up and get a bit of supper, and that leaves three hours for our houting like; for mother don't hexpect us back 'fore 'alf-past twelve. But I don't say I wouldn't come, as it's the 'alf day, if Tom's very pressin', she continues. 'I've 'eard it said them grand ladies as sits in the boxes and the stalls 'as low dresses on, like so many h'actrices, and h'it's as good as a play jist to look on 'em. So 'Arry told me, and 'e's a rare 'un for liking the look of them lords and ladies as lives up there.'

The pale, weary girl stitches silently by my side. She works harder than the others-finished four pair yesterday and hopes to finish the same to day. 'Are you chapel?' she asks presently.

'Yes,' I reply, attending more to the spirit than to the letter of her question.

'Do you belong to the Army?' she says inquiringly, glancing at my plain gray dress, and no doubt remembering my close black bonnet.

'No,' I answer, 'do you?'

She shakes her head: 'they've tried to get me to join since I've been in London. But we're a quieter set than they. Mother and I have only been in London these two years since father's death,' she adds in an explanatory tone. 'Mother's a skilled vest hand; not this sort of work-she wouldn't look at this. She can make $£_{2}$ a week in good times ; but now her eyesight's going fast. And it isn't much as I carn. I was brought up to teaching.'

'And why did you not go on with it?'

' $I$ failed in the first examination. Then father died, and mother heard there were skilled hands wanted in London, so we left our home. But I've found a Bible-class in our street and I teaches there twice a week. That and the chapel on a Sunday is like a bit of the old home.' The work-girl sighs, and the far-off look of 'another world' gleams in the clear depths of her gray eyes. 'If you're 
going out for the dinner-hour, I might show you the chapel and the class-room,' she adds with hesitating gentleness; 'are you going home for dinner?'

'No, I shall get a cup of tea at Lockhart's, and a bun.'

'Why, you're niver a-goin' to dine off that!' cries the girl on my other side. And there is a whispering all round the table. Only a cup of tea and a bun means great poverty.

'You 'ad no tea last evening,' continues the same girl; ' now you must take a cup o' mine this afternoon.'

The hours of the day pass away quietly in work. There are no words between the mistress and the pressers, and the workshop life becomes monotonous. During the interval between dinner and tea a golden - haired young lady (married daughter of the Jewess), beautifully gloved and bonneted, covered with jewels, but with a somewhat unseasonable tippet of sable-tails, enters the workroom. She seats herself by her mother at the head of the table and chats confidentially. I hear the names of various racehorses and of forthcoming races. Apparently her husband belongs to the genus of 'betting men,' and, judging from her dress, he is a successful one. The mistress is in high good humour. At tea-time she turns to me:

'Now, I'm very much interested in you ; there is something in your face that's uncommon, and your voice too, that's odd-no words higher than another. The woman here will tell you, if I hadn't taken a fancy to your face and your voice I should have bundled you out long ago. Now what have you been?' she continues with gracious inquisitiveness.

'I hadn't to work when my father was in work,' I answer with literal truthfulness.

'A tidy-looking young person like you ought to get some respectable man to marry her-like my daughter here; you're more fit for that than to be making your own living in this sort of place. But, since you have come, I'll see what I can do with you. Come, you're getting on nicely,' she says encouragingly, as she looks over my work. 
I am drinking the cup of tea forced on me by my neighbour. The pale, weary girl is munching her bread and butter.

'Won't you have some?' she says, as she pushes the paper towards me.

'No, thank you,' I answer.

'Sure?' and without more to do she lays a thick slice in my lap and turns away to avoid my thanks. A little bit of human kindness that goes to the heart and brings tears into the eyes of the investigator.

Work begins again. My friend has finished her third piece and is waiting for the fourth. She covers her head with her hands as she bends backward to rest the strained figure. In her gray eyes there is a look of intense weariness -weariness of body and mind. Another pair is handed to her and she begins again. She is a quick worker ; but, work as hard as she may, she cannot clear much over Is. a day after she has paid for trimmings. (A shilling a day is about the price of unskilled woman's labour.)

Another two hours and I say good-night.

'I'll be married in a week' are the last words I hear passing from Jo to Harry, 'and then my wife shall keep me.'

'I'll go to the bl-y workhouse,' jokes Harry, ' if I don't get a gal to keep me. I won't sweat here any longer for 5s. a day.' ${ }^{1}$

1 The East End workshop life here described is dealt with from other standpoints in the following chapters on 'The Jews of East London,' 'Women's Wages,' 'Women and the Factory Acts,' and 'How to do away with the Sweating System.' For a systematic description of the Tailoring Trade of East London, see the chapter contributed by the author to Mr. Charles Booth's Life and Labour of the People, vol. iv. of revised edition. 


\section{CHAPTER II}

\section{THE JEWS OF EAST LONDON ${ }^{1}$}

IN the midst of the chaotic elements of East London, the Jewish Settlement stands out as possessing a distinct religious and social life, and a definite history of its own.

Over 200 years ago a small body of well-to-do Spanish and Portuguese Jews from Amsterdam settled in the neighbourhood of Houndsditch. They were permitted to erect the first English synagogue immediately outside the eastern boundary of the City, and they were allotted a field in the Mile End waste wherein to bury their dead. From that time onward the Jewish Community of the East End increased in numbers and gradually changed in character.

With the slow decay of the unwritten law of social prejudice, whereby the children of Israel had been confined to one district of the metropolis, the aristocratic and cultured Sephardic Jews-direct descendants of the financiers, merchant princes, and learned doctors of Spain and Portugal - moved westward, and were replaced in their old homes by a multitude of down-trodden, poor, and bigoted brethren of the Ashkenazite, or German, branch of the Hebrew race. Thus towards the middle of last century the East End settlement ceased to be the nucleus of a small and select

1 Contributed in 1889 to Mr. Charles Booth's Life and Labour of the People (now in vol. iii. of revised edition). The author is indebted to many members of the Jewish community for their never-failing courtesy and help; and especially to the Chief Rabbi (Rev. Hermann Adler) for valuable information concerning the religious and charitable organisation of the East End Jewish Settlement. 
congregation of the chosen people, and became a reservoir for the incoming stream of poverty-stricken foreigners.

For a time the old settlers held aloof from the newcomers, and regarded them as a lower caste, fit only to receive alms. But with the growth of an educated and comparatively wealthy class from out of the ranks of the Ashkenazite congregations, the contemptuous feelings of the Sephardim declined. In I 760 , the whole of the Jewish people resident in England (numbering some 8000 souls) were organised under the secular leadership of the London Committee of Deputies of British Jews, a committee consisting of representatives from all the metropolitan and provincial congregations. And whilst the Jews were regarded as aliens by the English law, and while they laboured under manifold industrial and political disabilities, the Board of Deputies was fully recognised by the Imperial Government as a representative body, and possessed very real powers within its own community. The annals of this Board are interesting, for they illustrate the skill, the tenacity, and, above all, the admirable temper with which our Hebrew fellowcountrymen have insinuated themselves into the life of the nation, without forsaking the faith of their forefathers or sacrificing as a community the purity of their race. As an organisation the Board of Deputies is still retained, but its importance has naturally declined with the fulfilment of the main object of its existence.

Whilst the Board of Deputies has watched over the interests of its constituents as they have been affected by the Gentile world, the Beth Din (court of judgment) has administered ecclesiastical law within the Jewish community. For the origin of this venerable institution we must seek far back into primitive Hebrew history-into the annals of Biblical Judaism. In more modern times, during the wanderings of Israel among the western nations and the separation of the tribes into small communities, these courts have served a twofold purpose : they have introduced order and discipline within the several communities of the chosen 
people, and they have obviated the scandal of Jew fighting Jew in the Gentile courts of law.

In England at the present time the Beth Din consists of the Chief Rabbi and two assessors; the court sits twice every week throughout the year. We say that its jurisdiction is ecclesiastical, because justice is administered by a priest, and according to the laws of the Jewish religion. But we must not fail to remember that with the followers of the Law of Moses the term ecclesiastical covers the whole ground of moral duties as well as the minutiæ of religious ceremony-includes practical obedience to the ten commandments, as well as conformity to traditional observances. In fact, religion with the orthodox Jew is not simply, or even primarily, a key whereby to unlock existence in a future world; it is a law of life on this earth, sanctioned by the rewards and punishments of this world-peace or distraction, health or disease. Hence it is impossible to define the exact jurisdiction of the Beth Din. On the one hand, the Chief Rabbi and the two assessors regulate the details of religious observance and control the machinery whereby the sanitary and dietary regulations are enforced; on the other hand, they sit as a permanent board of arbitration to all those who are, or feel themselves, aggrieved by another son, or daughter of Israel. Family quarrels, trade and labour disputes, matrimonial differences, wife desertions, even reckless engagements, and breach of promise casesin short, all the thousand and one disputes, entanglements, defaults and mistakes of every-day life-are brought before the Beth Din to be settled or unravelled by the mingled lights of the Pentateuch, the Talmud, and the native shrewdness of the Hebrew judge.

Akin to the jurisdiction of the Beth Din is the religious registration of all marriages. No Jew can enter into the married state without first obtaining the consent of the Chief Rabbi. In the case of native Jews this permission may be considered as formal; but with immigrants from distant homes, sufficient testimony is required that the 
parties concerned have not already contracted with other mates the bonds and ties of wedlock.

These institutions are common to the Anglo-Jewish community throughout England. ${ }^{1}$ They are based on a representative system of a somewhat restricted character. Each seat-holder in a recognised synagogue takes part in the election of the Rabbi, wardens, and other officers of the congregation to which he belongs; every synagogue contributing to the communal fund has a right to vote for the Chief Rabbi, the Central Committee of Synagogues, and indirectly for the Board of Deputies.

The Jewish settlement at the East End, however, stands outside the communal life, so far as voting power is concerned-partly on account of its extreme poverty, and partly because of the foreign habits and customs of the vast majority of East End Jews.

For the East End Jews of the working class rarely attend the larger synagogues (except on the Day of Atonement), and most assuredly they are not seat-holders. For the most part the religious-minded form themselves into associations (chevras), which combine the functions of a benefit club for death, sickness, and the solemn rites of mourning with that of public worship and the study of the Talmud. Thirty or forty of these chevras are scattered throughout the Jewish quarters; they are of varying size as congregations, of different degrees of solvency as friendly societies, and of doubtful comfort and sanitation as places of public worship. Usually each chevras is named after the town or district in Russia or Poland from which the majority of its members have emigrated : it is, in fact, from old associations-from ties of relationship or friendship, or, at least, from the memory of a common home-that the new association springs.

Here, early in the morning, or late at night, the devout

1 The Board of Deputies represents all British Jews; but the Sephardic and Ashkenazite communities have each a distinct religious organisation and a separate Chief Rabbi. 
members meet to recite the morning and evening prayers, or to decipher the sacred books of the Talmud. And it is a curious and touching sight to enter one of the poorer and more wretched of these places on a Sabbath morning. Probably the one you choose will be situated in a small alley or narrow court, or it may be built out in a back yard. To reach the entrance you stumble over broken pavement and household débris; possibly you pick your way over the rickety bridge connecting it with the cottage property fronting the street. From the outside it appears a long wooden building surmounted by a skylight, very similar in construction to the ordinary sweater's workshop. You enter; the heat and odour convince you that the skylight is not used for ventilation. From behind the trellis of the 'ladies' gallery' you see at the far end of the room the richly curtained Ark of the Covenant, wherein are laid, attired in gorgeous vestments, the sacred scrolls of the Law. Slightly elevated on a platform in the midst of the congregation, stands the reader or minister, surrounded by the seven who are called up to the reading of the Law from among the congregation. Scarves of white cashmere or silk, softly bordered and fringed, are thrown across the shoulders of the men, and relieve the dusty hue and disguise the Western cut of the clothes they wear. A low, monotonous, but musical-toned recital of Hebrew prayers, each man praying for himself to the God of his fathers, rises from the congregation, whilst the reader intones, with a somewhat louder voice, the recognised portion of the Pentateuch. Add to this rhythmical cadence of numerous voices, the swaying to and fro of the bodies of the worshippers-expressive of the words of personal adoration : 'All my bones exclaim, O Lord, who is like unto Thee!' -and you may imagine yourself in a far-off Eastern land. But you are roused from your dreams. Your eye wanders from the men, who form the congregation, to the small body of women who watch behind the trellis. Here, certainly, you have the Western world, in the bright- 
coloured ostrich feathers, large bustles, and tight - fitting coats of cotton velvet or brocaded satinette. At last you step out, stifled by the heat and dazed by the strange contrast of the old-world memories of a majestic religion and the squalid vulgarity of an East End slum.

And, perchance, if it were permissible to stay after Divine service is over, and if you could follow the quick spoken Jüdisch, you would be still more bewildered by these 'destitute foreigners,' whose condition, according to Mr. Arnold White, 'resembles that of animals.' The women have left; the men are scattered over the benches (maybe there are several who are still muttering their prayers), or they are gathered together in knots, sharpening their intellects with the ingenious points and subtle logic of the Talmudical argument, refreshing their minds from the rich stores of Talmudical wit, or listening with ready helpfulness to the tale of distress of a new-comer from the foreign home.

These chevras supply the social and religious needs of some 12,000 to 15,000 foreign Jews. ${ }^{1} U_{p}$ to late years their status within the Jewish community has been very similar to that of dissenting bodies in face of a State Church, always excepting nonconformity of creed. No marriages could be celebrated within their precincts, and they were in no way represented on the Central Council of the Ashkenazite organisation of the United Synagogues. And owing to the unsanitary and overcrowded state of the poorest chevras, some among the leaders of the Anglo-Jewish community have thought to discourage the spontaneous multiplication of these small bodies, and to erect a large East End synagogue endowed by the charity of the West. I venture to think that wiser counsels have prevailed. The evils of bad sanitation and overcrowding are easily noted, and still more frequently exaggerated. Philanthropists are apt to

1 This figure includes women and children. See evidence of Mr. Joseph Blank (Secretary of the Federation of Minor Synagogues), before the Select Committee on Foreign Immigration, 1889. 
forget that different degrees of sanitation and space, like all the other conditions of human existence, are good, bad, or indifferent relatively to the habits and constitutions of those who submit to them. The close and odorous atmosphere of the ordinary cheoras is clearly a matter of choice; there is not even the ghost of a 'sweater' to enforce it. In truth, the family occupying one room, the presser or machinist at work day and night close to a coke fire, would find, in all probability, a palace to worship in draughty and uncomfortable, and out of all harmony and proportion with the rest of existence. On the other hand, it is easy to overlook the unseen influence for good of selfcreating, self-supporting, and self-governing communities; small enough to generate public opinion and the practical supervision of private morals, and large enough to stimulate charity, worship, and study by communion and example. These and other arguments have led to the federation of minor synagogues and their partial recognition by the communal authorities. And probably it is only a question of time before the East End cheoras are admitted to full representation in the religious organisation of the Ashkenazite community in return for a more responsible attitude with regard to the safety and sanitation of the premises they occupy.

The large City and East End Synagogues meet the religious wants of the middle and lower middle class of East End Jews; the chevras connect a certain number of the more pious and independent minded of the foreign settlers with the communal life; but there remains some 20,000 to 30,000 Jews - men, women, and children-too poor or too indifferent to attend regularly a place of worship, but who nevertheless cling with an almost superstitious tenacity to the habits and customs of their race. This poorest section of the Jewish community is composed, with few exceptions, of foreigners or the children of foreigners. Individuals are constantly rising out of it into other classes, or leaving England for America; but their places are 
quickly taken by new-comers from Poland and Russia. It forms, therefore, a permanent layer of poverty verging on destitution. Now this class is united to the Jewish middle and upper class by a downward stream of charity and personal service, a benevolence at once so widespread and so thorough-going, that it fully justifies the saying, 'All Israel are brethren.' 1 Of the many educational and charitable institutions connected with the East End Jewish life, I have only space to mention one-the most talked of and the least understood-the Jewish Board of Guardians.

The title of this institution has been unfortunate, for it has led to a serious misunderstanding. The Christian world has considered the 'Jewish Board of Guardians' as analogous in function to an English parochial body; the relief it administers has been treated as official or State relief, and therefore by a simple process of deduction its clients have been regarded as belonging to the ordinary pauper class. On the basis of this misleading analogy a calculation has been made of the percentage of the pauper class within the Jewish community; and the communal authorities have been charged with a wholesale pauperisation of the Jewish poor. ${ }^{2}$ A slight sketch of the origin of the Jewish Board of Guardians and of the actual nature of its activity will, I think, suffice to destroy the groundwork of this unmerited accusation.

From the first years of the Jewish settlement in England the influx of poverty-stricken co-religionists has been one of

1 A complete list of official Jewish Charities will be found in Dickens's London. The 'Free School,' the largest public school in England, is a striking example of the admirable organisation peculiar to Jewish charity.

2 This charge was based on the Report of the Jewish Board of Guardians for 1886 ; and an alarmist article on the extent of Jewish pauperism appeared in the Spectator, 22nd April 1887. Besides the relief administered by the Jewish Board of Guardians, free funerals were cited as indicative of pauperism. Those who understand the peculiar solemnity of mourning and funeral rites among Jews, and who appreciate the direct and indirect costliness of these, will perceive that a 'free funeral' is no more a token of pauperism than a free mass among Catholics or a free sermon among Protestants. The same may be said for the free distribution of the articles of diet needed for the celebration of religious feasts. 
the central problems of Anglo-Jewish life. In I753 the Great Synagogue tried to check immigration by refusing relief to those who had left their country without due cause. But persecution and social ostracism abroad, increasing liberty and consideration in England, combined with the warm-hearted benevolence of the more fortunate children of Israel for their poorer brethren, were social forces too strong to be curbed by the negative resolution of an official body. Charities increased on all sides, but in a chaotic state, giving rise to the worst forms of pauperism and professional begging. And those who have some experience of the present system of almsgiving practised by Christians of all denominations within the metropolis, and who are able to imagine the effect of that system intensified by a steady influx of destitute foreigners, and by the very practical view the Jews take of the religious precept of charity, will readily conceive the hopelessly demoralised condition of the Jewish poor for the first fifty years of the century. To put an end to this confusing of good and evil, the three City Ashkenazite congregations instituted, in I 858, the Jewish Board of Guardians. It became the Charity Organisation Society of the private benevolence of Hebrew philanthropists; only, from the first, it received generous and loyal support from the whole Jewish community.

Again, if we turn from the origin of the Jewish Board of Guardians to the nature of its work, we shall see that a large proportion of its charitable expenditure is not in any way analogous to the relief administered by a parochial Board. Of the $£_{\mathrm{I}} 3,000$ to $£_{\mathrm{I}} 4,000$ expended annually by the Jewish Board in actual relief, only $£ 2000$ a year is given away in a form similar to outdoor relief, viz. in fixed allowances, and in tickets for the necessaries of life; $£ .3000$ a year is lent for trade and business purposes; $£ \mathrm{I} 000$ a year is expended in emigration; another $£_{500}$ in the sanitary inspection of the homes of the poor and in the provision of a workroom for girls. Of the remainder more than 50 per cent may be considered given in the form of 
business capital of one kind or another, enabling the recipients to raise themselves permanently from the ranks of those who depend on charity for subsistence. Indeed, the practical effect of the relief administered by the Jewish Board, in so far as it affects individuals, is conclusively proved by the striking fact that of the 3313 cases dealt with in the year I 887 , only 268 were known to the Board as applicants prior to the year $\mathrm{I} 886$. If we remember the many thousands of cases treated during the Board's existence, we can hardly, in the face of these statistics, describe those relieved by the Jewish Board of Guardians as belonging to the chronically parasitic class of 'paupers.'

Hence if we mean by the word pauper, 'a person supported by State provision,' there are no paupers 'within the Jewish community, except a few isolated individuals chargeable to the English parochial authorities. If, on the other hand, we choose a wider definition-'a person so indigent as to depend on charity for maintenance'-it is impossible to measure the relative extent of pauperism among Christians and Jews of the same class. For the statistics of Jewish charitable relief are, comparatively speaking, definite and complete; but owing to the disorganised state of Christian charity, and owing to the fact that our indigent parasites are to a great extent maintained by the silent aid of the class immediately above them, we can by no possible means arrive at an approximate estimate of the number of persons in our midst who depend on charitable assistance for their livelihood. Who, for instance, would undertake to calculate the number of paupers (in this wider sense of the term) among the population surrounding the docks? Moreover, while all groundwork for the charge of pauperisation is absent, we have conclusive evidence that either from the character of those who take, or from the method of those who give, Jewish charity does not tend to the demoralisation of individual recipients.

But though the accusation of wholesale pauperism brought against the Jewish community cannot be main- 
tained, there is doubtless, from the standpoint of industrial health, a grave objection to the form of relief administered by the Jewish Board of Guardians. Money lent or given for trade purposes fosters the artificial multiplication of small masters, and is one of the direct causes of the sweating system; efficient assistance to the mechanic out of work enables him to exist on reduced or irregular earnings, and thereby lowers the general condition of his class. In truth, there seems no escape from the tragic dilemma of charitable relief. If we help a man to exist without work, we demoralise the individual and encourage the growth of a parasitic or pauper class. If, on the other hand, we raise the recipient permanently from the condition of penury, and enable him to begin again the struggle for existence, we save him at the cost of all those who compete with him (whether they be small masters or wage earners, Jews or Gentiles) for the custom of the manufacturer, the trader, or the consumer; in other words, we increase that very dislocation of industry, the result of which we attempt to mitigate in special instances. Judged by its effect on the industrial development of the whole nation, we are tempted to echo sorrowfully the words of Louise Michel, 'La Philanthropie, c'est une mensonge.'

Before I leave the question of charity and pauperism within the Jewish community, it is needful to notice certain institutions which indirectly have a most pauperising effect, and which would assuredly achieve the utter demoralisation of the Jewish poor if the work they accomplished equalled to any degree the sum of their expenditure-I mean the Christian conversionist societies. Among these the London Society for Promoting Christianity among the Jews is the largest and most influential.

This society enjoys an income of $£_{35,000}$ a year. On the magnificent premises of Palestine Place (Bethnal Green) it provides à chapel, a Hebrew missionary training institute, and a Hebrew operatives' home. During I 888 twelve Jews were baptized in its chapel, forty children (more than 
fifty per cent of whom were the children of Christian mothers) were maintained in the school, and twelve Jewish converts supported in the operatives' home. The process of conversion is very simple: board and lodging at a specially provided house during the inquiry stage, constant charitable assistance after conversion, and the free education and free maintenance of Jewish children brought up in the Christian faith. In the eloquent words of the Report:- 'The present inmates (Operative Jewish Converts' Institution) appear fully to realise the contrast between their former friendless condition and their present life, in which a comfortable home, wholesome food, respectable clothing, instruction in trade, and reward-money for attention and industry accumulates till they leave the institution.' The society has, however, one complaint against its converts. Inspired by the Jewish spirit of competing with former masters, and anxious to turn to some account their newly-acquired 'talent' of Christianity, the youthful proselytes set up in business on their own account, collecting and spending the subscriptions of zealous Christians, with no respect to the monetary claims or superior authority of the mother society. Hence the East End is sprinkled with small missions, between which and Palestine Place a certain number of professional converts wander in search of the temporal blessings of Christianity. Imagine the temptation to the poverty-stricken inhabitants of the crowded alleys of the Jewish slum! And yet, in spite of comfortable maintenance in the present and brilliant prospects in the future, the number of converts is infinitesimal, a fact that throws an interesting side-light on the moral tenacity of the Jewish race.

The movement, however, has produced a mischievous reaction within the community. Pious-minded Jews have thought starvation or baptism a too terrible alternative to offer the utterly destitute, and a certain amount of unorganised and pauperising relief is undoubtedly dispensed throughout the East End as a counterblast to missionary 
enterprise. Moreover, Jewish philanthropists have tried to protect the friendless immigrant (without hope or chance of immediate employment) from the allurements of the Christian missionary by the same means through which they have attempted to save him from the extortions of the professional 'runner.' They have erected a 'Poor Jews' Temporary Shelter,' an institution which last year provided board and lodging for a period of from one to fourteen days to 1322 homeless immigrants. Rightly or wrongly, this institution has been looked upon with disfavour by Christians, and to some extent by Jews (notably by the Jewish Board of Guardians) as likely to attract to England pauper foreigners of the Hebrew race.

I have sketched the principal religious and charitable institutions affecting for good or evil Jewish life at the East End. A far more difficult task lies before me: to give the reader some general idea of the manners and customs of this people; to represent to some slight extent their home and outdoor life, and finally to estimate, however imperfectly, their character and capacity as members of our social and industrial state.

I think I may begin with two statements of a general character: the majority of East End Jews are either foreigners or children of foreigners; and the dominant nationality is Polish or Russian.

With regard to the preponderance of foreigners, I hardly think it will be denied by any one who has studied the available statistics, or who has any personal experience of East End Jewish life.

For statistical material I refer the reader to Mr. Llewellyn Smith's careful and elaborate calculations. ${ }^{1}$ He estimates

1 Charles Booth, Life and Labour of the People (now in vol. iii. of revised edition). Mr. Smith's estimate of foreign Jews is partly based on the statistics of Jewish East End Schools. In the Jewish Free School, for instance, there are 3400 children ; 897 of these are foreign-born; 1962 are of foreign extraction, while 54I only are the children of English-born parents. In other East End schools the Jewish children are only divided into two classes-foreign-born and native-born - no distinction being made between children of foreign and of native parents. Mr. Smith has therefore dealt with the first class only, and has not 
that out of a total Jewish population of from 60,000 to 70,000 persons, 30,000 were actually born abroad. At least one-half of the remainder must be of foreign parentage. But if the reader distrusts statistics, I would advise him to wander through the Jewish quarter, and listen to the language of the streets ; to frequent the sweaters' dens, the gambling clubs, and the chevras; or, if he desires a more graphic experience, to attend a meeting of working-class Jews, and try to make himself understood in his native tongue.

The Polish or Russian nationality of the vast majority of these foreigners is an equally undisputed fact and a natural consequence of the recent outbreak of Judenhetze in Russian Poland and the adjoining territories. It is, moreover, a fact of great significance in any consideration of the East End Jewish question. For we are accustomed to think, with the old German proverb, 'Every country has the Jew it deserves,' a saying, in our case, inapt, since we receive our Jews ready-made-passed on to us by a foreign nation with a domestic policy diametrically opposed to our own. Before, therefore, we are able to appreciate the present characteristics and future prospects of this stream of Jewish life flowing continuously with more or less rapidity into the great reservoir of the East End Jewish settlement, we must gain some slight idea of the political, industrial, and social conditions governing the source from which it springs.

Alone among the great nations of Europe, Russia has resolutely refused political and industrial freedom to her Jewish subjects. Under the Russian Government oppression and restriction have assumed every conceivable form. No Jew may own land; in some places he may not even rent it; in one part he is not admitted into the learned professions; in another state he may not enter an industrial establishment

attempted to estimate the population of foreign parentage. A glance at the statistics of the Free School will show the numerical importance of this section of the Jewish population. The latest and most authoritative figures are to be found in Mr. Joseph Jacob's Statistics of the Jewish Population in London, 1873-1893 (London, I894). 
or take part in a Government contract; while in whole districts of Russia the children of Israel have no right of domicile, and live and trade by the bought connivance of the police authorities, and in daily terror of the petty tyranny of a capricious governor. Deprived of the rights and privileges of citizens, they are subject to the full strain of military conscription, intensified by social insult and religious persecution. And yet, in spite of this systematic oppression, the children of Israel have, up to late years, multiplied in the land of their enemies and prospered exceedingly, until they may be numbered by their millions throughout the Russian Empire; absorbing the more profitable trading, and crowding every profession, mechanical and intellectual, open to Jewish competition. Once again in the history of the world penal legislation has proved a powerless weapon against the superior mental equipment of the Jew; and it has simply forced the untiring energies of the Hebrew race into low channels of parasitic activity, undermining the morality and wellbeing of their Christian fellow-subjects. The Russian Government and the Russian people have slowly grasped this fact, and unwilling to adopt the policy of complete emancipation, they have changed their method of attack. The central authorities, supported by the public opinion of the injured classes, have deliberately encouraged mob-violence of a brutal and revolting character as a costless but efficient means of expulsion. Robbed, outraged, in fear of death and physical torture, the chosen people have swarmed across the Russian frontier, bearing with them, not borrowed 'jewels of silver, and jewels of gold, and raiment,' ${ }^{1}$ but a capacity for the silent evasion of the law, a faculty for secretive and illicit dealing, and mingled feelings of contempt and fear for the Christians amongst whom they have dwelt, and under whose government they have lived for successive generations.

These have been the outward circumstances forming the

1 Exodus xii. 35. 
Polish or Russian Jew. The inner life of the small Hebrew communities bound together by common suffering and mutual helpfulness has developed other qualities, but has also tended in its own way to destroy all friendly and honourable intercourse with surrounding peoples. Social isolation has perfected home life; persecution has intensified religious fervour, an existence of unremitting toil, and a rigid observance of the moral precepts and sanitary and dietary regulations of the Jewish religion have favoured the growth of sobriety, personal purity, and a consequent power of physical endurance. But living among a half-civilised people, and carefully preserved by the Government from the advantages of secular instruction, the Polish and Russian Jews have centred their thoughts and feelings in the literature of their race-in the Old Testament, with its magnificent promises of universal dominion; in the Talmud, with its minute instructions as to the means of gaining it. The child, on its mother's lap, lisps passages from the Talmud; the old man, tottering to the grave, is still searching for the secret of life in 'that stupendous labyrinth of fact, thought, and fancy.' For in those ten volumes of Talmudical lore the orthodox Polish Jew finds not only a storehouse of information and a training-ground for his intellectual and emotional faculties, but the key to all the varied perplexities and manifold troubles of his daily existence. To quote the words of Deutsch, the Talmud, besides comprising the poetry and the science of the people, is 'emphatically a Corpus Juris: an encyclopædia of law, civil and penal, ecclesiastical and international, human and divine.' Beyond this law the pious Israelite recognises no obligations; the laws and customs of the Christians are so many regulations to be obeyed, evaded, set at naught, or used according to the possibilities and expediences of the hour.

In these facts of past training we see an explanation of the present mental and physical qualities of the majority of East End Jews. The Polish or Russian Jew represents to 
some extent the concentrated essence of Jewish virtue and Jewish vice; for he has, in his individual experience, epitomised the history of his race in the Christian world. But he can in no sense be considered a fair sample of Jews who have enjoyed the freedom, the culture, and the public spirit of English life. I should wish it, therefore, to be distinctly understood that I do not offer the slight description in the following pages of the manners, customs, and industrial characteristics of East End Jews as a picture of the Jewish community throughout England.

Let us imagine ourselves on board a Hamburg boat steaming slowly up the Thames in the early hours of the morning. In the stern of the vessel we see a mixed crowd of men, women, and children-Polish and Russian Jews, some sitting on their baskets, others with bundles tied up in bright coloured kerchiefs. For the most part they are men between 20 and 40 years of age, of slight and stooping stature, of sallow and pinched countenance, with low foreheads, high cheek bones, and protruding lips. They wear uncouth and dirt-bespattered garments, they mutter to each other in a strange tongue. Scattered among them a few women (their shapely figures and soft skins compare favourably with the sickly appearance of the men), in peasant frocks with shawls thrown lightly over their heads; and here and there a child, with prematurely set features, bright eyes and agile movements. Stamped on the countenance and bearing of the men is a look of stubborn patience; in their eyes an indescribable expression of hunted, suffering animals, lit up now and again by tenderness for the young wife or little child, or sharpened into a quick and furtive perception of surrounding circumstances. You address them kindly, they gaze on you with silent suspicion; a coarse German sailor pushes his way amongst them with oaths and curses ; they simply move apart without a murmur, and, judging from their expression, without a resentful feeling; whilst the women pick up their ragged bundles from out of the way of the intruder with an air of deprecating gentleness. 
The steamer is at rest, the captain awaits the visit of the Custom-house officials. All eyes are strained, searching through the shifting mist and dense forest of masts for the first glimpse of the eagerly-hoped-for relations and friends, for the first sight of the long-dreamt-of city of freedom and prosperity. Presently a boat rows briskly to the side of the vessel; seated in it a young woman with mock sealskin coat, vandyke hat slashed up with blue satin, and surmounted with a yellow ostrich feather and long six-buttoned gloves. She is chaffing the boatman in broken English, and shouts words of welcome and encouragement to the simple bewildered peasant who peers over the side of the vessel with two little ones clasped in either hand. Yes! that smartly dressed young lady is her daughter. Three years ago the father and the elder child left the quiet Polish village : a long interval of suspense, then a letter telling of an almost hopeless struggle, at last passage money, and here to-day the daughter with her bright warm clothes and cheery self-confidence-in a few hours the comfortably furnished home of a small wholesale orange-dealer in Mitre Street, near to Petticoat Lane.

Seated by the side of the young woman a bearded man, his face furrowed and shoulders bent with work. $\mathrm{He}$ is comfortably clothed, and wears a large watch-chain hanging ostentatiously outside his coat. Evidently he is not the father of the girl, for his hands are clenched nervously as he fails to catch sight of the long-expected form; he is simply the presser from the sweater's next door to the orange dealer; and he also can afford the Is. fee to board the steamer and meet his wife. Ah! there she is! and a gentle-faced woman, beaming with heightened colour, pushes her way to the side of the vessel, holding up the youngest child with triumphant pride. The elder boy, a lad of ten, fastens his eyes fixedly on his father's watch-chain, tries in vain to pierce the pocket and weigh and measure the watch, calculates quickly the probable value, wonders whether gilded articles are cheaper or dearer in London than in Poland, and 
registers a silent vow that he will not rest day nor night until he is handling with a possessor's pride a gold chain and watch, similar or superior to that adorning his father's person. Then he prepares with religious reverence to receive his father's blessing.

The scenes at the landing-stage are less idyllic. There are a few relations and friends awaiting the arrival of the small boats filled with emigrants: but the crowd gathered in and about the gin-shop overlooking the narrow entrance of the landing-stage are dock loungers of the lowest type and professional 'runners.' These latter individuals, usually of the Hebrew race, are among the most repulsive of East London parasites; boat after boat touches the landing-stage, they push forward, sieze hold of the bundles or baskets of the new-comers, offer bogus tickets to those who wish to travel forward to America, promise guidance and free lodging to those who hold in their hands addresses of acquaintances in Whitechapel, or who are absolutely friendless. A little man with an official badge (Hebrew Ladies' Protective Society) fights valiantly in their midst for the conduct of unprotected females, and shouts or whispers to the others to go to the Poor Jews' Temporary Shelter in Leman Street. For a few moments it is a scene of indescribable confusion: cries and counter-cries; the hoarse laughter of the dock loungers at the strange garb and broken accent of the poverty-stricken foreigners; the rough swearing of the boatmen at passengers unable to pay the fee for landing. In another ten minutes eighty of the hundred new-comers are dispersed in the back slums of Whitechapel; in another few days, the majority of these, robbed of the little they possess, are turned out of the 'free lodgings' destitute and friendless.

If we were able to follow the 'greener' into the next scene of his adventures we should find him existing on the charity of a co-religionist or toiling day and night for a small labour-contractor in return for a shake-down, a cup of black coffee, and a hunch of brown bread. This 
state of dependence, however, does not last. For a time the man works as if he were a slave under the lash, silently, without complaint. But in a few months (in the busy season in a few weeks) the master enters his workshop and the man is not at his place. He has left without warning-silently-as he worked without pay. $\mathrm{He}$ has learnt his trade and can sell his skill in the open market at the corner of Commercial Street; or possibly a neighbouring sweater, pressed with work, has offered him better terms. A year hence he has joined a chevras, or has become an habitué of a gambling club. And unless he falls a victim to the Jewish passion for gambling, he employs the enforced leisure of the slack season in some form of petty dealing. He is soon in a fair way to become a tiny capitalist-a maker of profit as well as an earner of wage. He has moved out of the back court in which his fellow-countrymen are herded together like animals, and is comfortably installed in a model dwelling; the walls of his parlour are decked with prints of Hebrew worthies, or with portraits of prize-fighters and race-horses; his wife wears jewellery and furs on the Sabbath; for their Sunday dinner they eat poultry. He treats his wife with courtesy and tenderness, and they discuss constantly the future of the children. $\mathrm{He}$ is never to be seen at the public-house round the corner; but he enjoys a quiet glass of 'rum and shrub' and a game of cards with a few friends on the Saturday or Sunday evening; and he thinks seriously of season tickets for the People's Palace. He remembers the starvation fare and the long hours of his first place: he remembers, too, the name and address of the wholesale house served by his first master; and presently he appears at the counter and offers to take the work at a lower figure, or secures it through a tip to the foreman. But he no longer kisses the hand of Singer's agent and begs with fawning words for another sewing-machine; neither does he flit to other lodgings in the dead of night at the first threat of the broker. In short, he has become a 
law-abiding and self-respecting citizen of our great metropolis, and feels himself the equal of a Montefiore or a Rothschild.

The foregoing sketch is typical of the lives of the majority of Polish and Russian Jews from their first appearance in the port of London. Usually they bring with them no ready-made skill of a marketable character. They are set down in an already over-stocked and demoralised labour market; they are surrounded by the drunkenness, immorality, and gambling of the East End streets; they are, in fact, placed in the midst of the very refuse of our civilisation, and yet whether they become bootmakers, tailors, cabinetmakers, glaziers, or dealers, the Jewish inhabitants of East London rise in the social scale; 'as a mass they shift upwards, leaving to the new-comers from foreign lands and to the small section of habitual gamblers the worst-paid work, the most dilapidated workshops, and the dirtiest lodgings.' 1 But this is not all. Originally engaged in the most unskilled branch of the lowest section of each trade, Jewish mechanics (whether we regard them individually or as a class) slowly but surely invade the higher provinces of production, bringing in their train a system of employment and a method of dealing with masters, men, and fellow-workers which arouses the antagonism of English workmen. The East End Jewish problem, therefore, resolves itself into two central questions:-(I) What are the reasons of the Jews' success? (2) Why is that success resented by that part of the Christian community with whom the Jew comes in daily contact? I venture to end this chapter with a few suggestions touching this double-faced enigma of Jewish life.

First we must realise (in comparing the Polish Jew with the English labourer) that the poorest Jew has inherited through the medium of his religion a trained intellect. For within the Judaic Theocracy there are no sharp lines

1 'The Tailoring Trade' in Mr. Charles Booth's Life and Labour of the People (now in vol. iv. of revised edition). 
dividing the people into distinct classes with definite economic characteristics such as exist in most Christian nations : viz. a leisure class of landowners, a capitalist class of brain-workers, and a mass of labouring people who up to late years have been considered a lower order, fit only for manual work.

The children of Israel are a nation of priests. Each male child, rich or poor, is a student of the literature of his race. In his earliest childhood he is taught by picturesque rites and ceremonies the history, the laws, and the poetry of his people; in boyhood he masters long passages in an ancient tongue; and in the more pious and rigid communities of Russian Poland the full-grown man spends his leisure in striving to interpret the subtle reasoning and strange fantasies of that great classic of the Hebrews, the Talmud. I do not wish to imply that the bigotted Jew is a 'cultured' being, if we mean by culture a wide experience of the thoughts and feelings of other times and other races. Far from it. The intellectual vision and the emotional sympathies of the great majority of Polish Jews are narrowed down to the past history and present prospects of their own race. But the mechanical faculties of the intellect-memory, the power of sustained reasoning, and the capacity for elaborate calculation have been persistently cultivated (in orthodox communities) among all classes, and there has resulted a striking equality; and a high though narrow level of intellectual training.

This oneness of type and uniformity of chances, originating in the influence of a unique religion, have been strengthened and maintained by the industrial and political disabilities under which the Jews have laboured through the greater part of the Christian era, and which still exist in Russian Poland. The brutal persecution of the Middle Ages weeded out the inapt and incompetent. Injustice and social isolation, pressing on poor and rich alike, sharpened and narrowed the intellect of Israel, regarded as a whole, to an instrument for grasping by mental agility the good 
things withheld from them by the brute force of the Christian peoples.

In the Jewish inhabitants of East London we see therefore a race of brain-workers competing with a class of manual labourers. The Polish Jew regards manual work ${ }^{1}$ as the first rung of the social ladder, to be superseded or supplanted on the first opportunity by the estimates of the profit-maker, the transactions of the dealer, or the calculations of the money-lender ; and he is only tempted from a life of continual acquisition by that vice of the intellect, gambling.

Besides the possession of a trained intellect, admirably adapted to commerce and finance, there is another, and I am inclined to think a more important factor in the Jew's success. From birth upwards, the pious Israelite (male and female) is subjected to a moral and physical regimen, which, while it favours the full development of the bodily organs, protects them from abuse and disease, and stimulates the growth of physical self-control and mental endurance. ${ }^{2}$ For the rites and regulations of the Mosaic law and the more detailed instructions of tradition are in no way similar to the ascetic exercises of the Christian or Buddhist saint seeking spiritual exaltation through the mortification or annihilation of physical instinct. On the contrary, the religious ordinances and sanitary laws of the Jewish religion accentuate the physical aspect of life; they are (as M. Rénan has observed) not a preparation for another world, but a course of training adapted to prolong the life of the individual and to multiply the number of his descendants.

1 It is a mistake to suppose that the Jew is physically unfit for manual work. On the contrary, he is better fitted than the Anglo-Saxon for those trades which require quickness of perception rather than artistic skill, and he will compete sucessfully with the Englishman in forms of manual labour needing physical endurance, and not actual strength of muscle. Hence the Jew's success in the machine-made Coat and Boot and Shoe Trades.

2 From a psychological as well as from an ethical point of view, a detailed study of the sanitary observances of the Jewish religion (more especially those relative to sexual functions) would be extremely interesting. The musical talent which distinguishes the Hebrew race has been ascribed by psychologists to the effect of these observances on successive generations. 
Moreover, the moral precepts of Judaism are centred in the perfection of family life, in obedience towards parents, in self-devotion for children, in the chastity of the girl, in the support and protection of the wife. The poorest Jew cherishes as sacred the maternity of the woman, and seldom degrades her to the position of a worker upon whose exertions he depends for subsistence. Thus Jewish morality, instead of diverting feeling from the service of the body, combines with physical training to develop exclusively that side of man's emotional nature which is inextricably interwoven with the healthful and pleasurable exercise of physical instinct. Hence in the rigidly conforming Jew we have a being at once moral and sensual; a creature endowed with the power of physical endurance, but gifted with a highlytrained and well-regulated appetite for sensuous enjoyment. And with the emotions directed into the well-regulated channels of domestic feeling, the mind remains passionless. Anger, pride, and self-consciousness, with their counterparts of indignation, personal dignity, and sensitiveness, play a small part in the character of the Polish Jew. He suffers oppression and bears ridicule with imperturbable good humour; in the face of insult and abuse he remains silent. For why resent when your object is to overcome? Why bluster and fight when you may manipulate or control in secret ?

The result is twofold. As an industrial competitor the Polish Jew is fettered by no definite standard of life $:^{1}$ it rises and falls with his opportunities; he is not depressed by penury, and he is not demoralised by gain. As a citizen of our many-sided metropolis he is unmoved by those gusts of passion which lead to drunkenness and crime; whilst, on the other hand, he pursues the main purposes of personal existence, undistracted by the humours, illusions, and aspirations arising from the unsatisfied emotions of our more

1 For further analysis of the economic importance of the customary 'standard of life,' and of its inexplicable variations, see Industrial Democracy, by Sidney and Beatrice Webb (London, I898), vol. ii. pp. 693-698. 
complicated and less disciplined natures. Is it surprising, therefore, that in this nineteenth century, with its ideal of physical health, intellectual acquisition, and material prosperity, the chosen people, with three thousand years of training, should in some instances realise the promise made by Moses to their forefathers: "Thou shalt drive out nations mightier than thyself, and thou shalt take their land as an inheritance'?

Such, I imagine, are the chief causes of the Jew's success. We need not seek far for the origin of the antagonistic feelings with which the Gentile inhabitants of East London regard Jewish labour and Jewish trade. For the reader will have already perceived that the immigrant Jew, though possessed of many first-class virtues, is deficient in that highest and latest development of human sentiment -social morality.

I do not wish to imply by this that East End Jews resist the laws and defy the conventions of social and commercial life. On the contrary, no one will deny that the children of Israel are the most law-abiding inhabitants of East London. They keep the peace, they pay their debts, and they abide by their contracts; practices in which they are undoubtedly superior to the English and Irish casual labourers among whom they dwell. For the Jew is quick to perceive that 'law and order' and the 'sanctity of contract' are the sine qua non of a full and free competition in the open market. And it is by competition, and by competition alone, that the Jew seeks success. But in the case of the foreign Jews, it is a competition unrestricted by the personal dignity of a definite standard of life, and unchecked by the social feelings of class loyalty and trade integrity. The small manufacturer injures the trade through which he rises to the rank of a capitalist by bad and dishonest production. The petty dealer or small money-lender, imbued with the economic precept of buying in the cheapest and selling in the dearest market, suits his wares and his terms to the weakness, the ignorance, and the 
vice of his customers; the mechanic, indifferent to the interests of the class to which he temporarily belongs, and intent only on becoming a small master, acknowledges no limit to the process of underbidding fellow-workers, except the exhaustion of his own strength. In short, the foreign Jew totally ignores all social obligations other than keeping the law of the land, the maintenance of his own family, and the charitable relief of co-religionists.

Thus the immigrant Jew, fresh from the sorrowful experiences typical of the history of his race, seems to justify by his existence those strange assumptions which figured for man in the political economy of Ricardo-an Always Enlightened Selfishness, seeking employment or profit with an absolute mobility of body and mind, without pride, without preference, without interests outside the struggle for the existence and welfare of the individual and the family. We see these assumptions verified in the Jewish inhabitants of Whitechapel; and in the Jewish East End trades we may watch the prophetic deduction of the Hebrew economist actually fulfilled-in a perpetually recurring bare subsistence wage for the great majority of manual workers. ${ }^{1}$

1 The reader wishing to know more of the history, organisation, and characteristics of the Jews in this country may be referred to The Jewish Year Book (London, Simpkin Marshall), a useful annual edited by Mr. Joseph Jacobs. The issue for $1897-8$ contains a list of English works of reference on various points connected with the Jews. Mention may be made also of Studies in Jervish Statistics by Joseph Jacobs; the annual reports of the Jewish Board of Guardians and the Russo-Jewish Committee; and the various Parliamentary Papers on Alien Immigration and the Sweating System. 


\section{CHAPTER III}

\section{WOMEN'S WAGES ${ }^{1}$}

WHEN I was asked to prepare a paper for the Economic Section of the British Association upon the alleged differences in the wages paid to men and to women for similar work, I felt very reluctant to undertake the task. The inferiority of women's earnings as compared with men's was notorious, but it was not so clear that this inferiority was unconnected with a real inferiority of work, either in quantity, quality, or nett advantageousness to the employer. The point has seldom been discussed in detail with any reference to the actual facts of modern industry, and I had come to no definite conclusion on the subject, still less had I any novel or original view to bring before the Association. But as it appeared to be unnecessary to do more than present the subject for discussion, I endeavoured to collect all the relevant facts I could discover, in the hope that they might suggest some fertile lines of subsequent investigation. The facts turned out to be of no small interest, and although I am bound to confess that further consideration of them brings me no nearer than before to any simple or universal generalisation, they are now republished in revised and more complete form, on the chance that they may be of use to economic students.

1 A paper read at the Economic Section of the British Association, 189r, and published in the Economic Journal, December 1891. For many of the facts quoted the author is indebted to the personal experience of the working-men and working-women members of the Fabian Society. 
There are generally assumed to be two rival methods of economic study. The one is supposed to start with a few simple principles, from which large conclusions are hypothetically drawn, to be compared with the facts of life. The other collects economic facts from which inductions can be made. Without accepting the truth of either of these descriptions, and, indeed, without in the least believing in their rivalry, I desire to present the following pages, as neither an inductive nor a deductive study, and, in fact, as nothing more than a preliminary survey of the field for investigation.

Women's work may be classed as (I) manual, (2) routine mental, (3) artistic, or (4) intellectual. These are, in the main, 'non-competing groups.'

\section{I.-Manual Labour}

\section{(a) Time Wages}

Women engaged in manual labour normally earn less than men in similar occupations. 'A lass aye gets less than a man' contentedly remarked an Edinburgh factory girl when questioned on the subject. Nor are statistics wanting to give definiteness to the popular view. The inquiry made by the Massachusetts Bureau of Statistics of Labour in I884, into the wages paid in the twenty-four principal manufacturing industries in Great Britain and Massachusetts respectively, yields the following result bearing on this point :-

1 Statistics rearranged from the Sixteenth Report of Massachusetts Bureau of Statistics of Labour, 1885. It is interesting to compare the ratio in Germany. Statistics of the twenty-eight large towns in 1897 show the mean rate for adult male labour to be $2 \mathrm{~s}$. 5 d. per day, and that for adult women, Is. $6 \mathrm{~d}$. per day (Labour Gazette, March 1898). 
Relative EARnings OF MEN AND Women in I 883

Average of I 7,430 employees in I I o establishments in Great Britain, and 35,902 employees in 210 establishments in Massachusetts, representing in both cases 24 different manufacturing industries.

\begin{tabular}{|c|c|c|c|c|c|c|}
\hline & \multicolumn{3}{|c|}{ GREAT BRITAin. } & \multicolumn{3}{|c|}{ Massachusetts. } \\
\hline & Men. & Women. & $\begin{array}{l}\text { Per cent } \\
\text { of Men's. }\end{array}$ & Men. & Women. & $\begin{array}{l}\text { Per cent } \\
\text { of Men's. }\end{array}$ \\
\hline Average highest weekly wage & $\begin{array}{l}\text { \$ct. } \\
\text { I J.36 }\end{array}$ & $\begin{array}{l}\text { \$ ct. } \\
\text { 4. IO }\end{array}$ & 36 & $\begin{array}{l}\$ \text { ct. } \\
25.4 \mathrm{I}\end{array}$ & $\begin{array}{l}\text { \$ ct. } \\
8.57\end{array}$ & 33 \\
\hline Average lowest weekly wage & $4 \cdot 72$ & 2.27 & 48 & 7.09 & 4.62 & \\
\hline Average weekly wage . & 8.26 & $3 \cdot 37$ & $4 \mathrm{I}^{2}$ & II. 85 & 6.09 & $5^{x^{3}}$ \\
\hline
\end{tabular}

It may be observed that the average weekly wage of these Massachusetts women workers, viz. \$6.09, is a little below the ascertained average of 1 I 83 Boston women workers in I 887 , viz. $\$ 293.44$ in a year, with $36 \frac{1}{2}$ days lost time; and it coincides almost exactly with the ascertained average of 13,822 women workers in twentytwo cities of the United States in that year, viz. \$272.45, for a year, with 36 days' lost time. ${ }^{1}$

The 'averages' for Great Britain were prepared from two different bases, both of which are given. Their divergence, though not in itself important, serves to emphasise the general untrustworthiness of statistical averages of wages. But this comparative table has been selected as being apparently more trustworthy than some other American statistics, and its main results coincide closely with other data. Without relying on its details, it may probably be safely inferred that the women employed in manufacturing industries earn only from one-third to two-thirds of the

1 Fourth Annual Report of Federal Commissioner of Labour, I888. Both these calculations exclude 'professional' occupations. 
amount earned by the men. The average wage of the women approaches nearest to that of the men in the textile manufactures (cotton goods, hosiery, and carpetings in Great Britain; woollens and worsteds in Massachusetts). Even at manual labour women occasionally earn high standard wages. Out of 13,822 workers in twenty-two cities of the United States, 537, or nearly 4 per cent, were found in 1887 to be earning $\$ 500$ a year, or over. ${ }^{1}$

\section{Average Weekly Earnings by Trades}

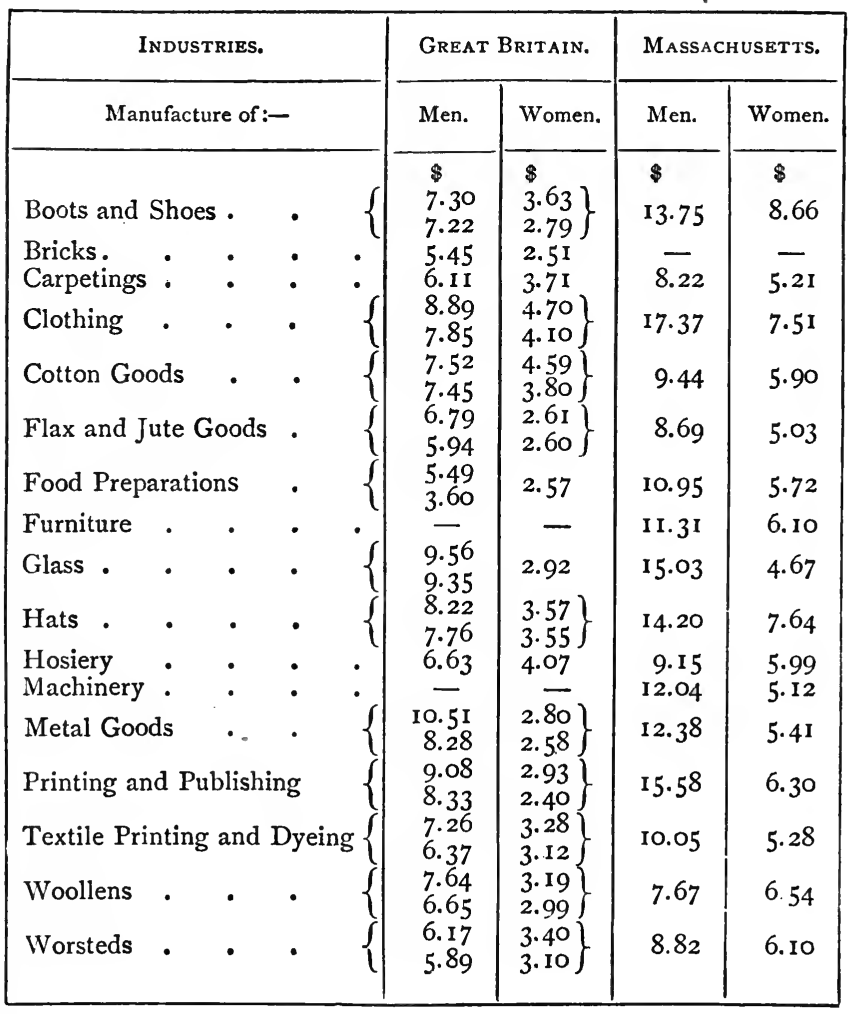

1 Fourth Annual Report of Federal Commissioner of Labour, 1888. 


\section{(b) Task Wages}

But even if it be true as a general statistical result that women earn less than men, it still remains necessary to inquire, by careful comparison of crucial instances, how far this inferiority of reward is merely a concomitant of inferiority of work. 'Time wages' of women might be less than those of men without their ' task wages' being lower. The chief difficulty in this problem is what seems to be the impossibility of discovering any but a very few instances in which men and women do precisely similar work, in the same place and at the same epoch.

When women are first introduced into a trade in substitution of men there are, generally speaking, two scales of wages, the men's old rate, and a lower one for the women. And there is a not unnatural tendency for the different grades of work to become very quickly divided between the two sexes, and even work which in one place is done almost exclusively by men will, in another place, be relegated equally exclusively to women.

The tailoring trade, for instance, in which both men and women work, affords, as I am told by competent investigators, no case fit for exact comparison. Both women and men can be found working as coat-machinists, but those in London are almost exclusively men, and it would be useless to compare the wages of the London male coat-machinist with those of provincial female coat-machinists. The few female coat-machinists in London perform work of much lower grade than the men. Similarly, the machining of trousers and waistcoats in London is performed exclusively by women. Under these circumstances it does not aid us to learn that the women employed in various branches of the tailoring trade in London earn only about half as much wages as the men employed in other branches.

On the other hand, I have been informed that in Glasgow, although the men and women employed in the ready-made clothing trade usually perform different kinds of work, yet men occasionally do the women's work, and (not unnaturally) they then receive no higher rates than the 
women. ${ }^{1}$ In Leeds too, it is said to be a matter of indifference to one clothing contractor whether the work is done by men or by women, the piece-work rates being the same. ${ }^{2}$

Again, in paper mills, where women and men are employed together in tying up reams of paper, the men tie up the heavier reams and are paid so much per $1000 \mathrm{lbs}$; the women tie up the lighter reams at so much per score of reams. Therefore, although the women earn less than the men, it is impossible to compare their work.

Similarly, in all the Birmingham trades, although many thousands of women are employed, I am told that in no instance do they do the same work as men.

I am inclined to believe that a similar state of things prevails in cigar-making. Here the men receive, in London, 4s. 2 d. to 5 s. 2 d. per 1000 , and earn 35 s. per week, whilst the women receive only Is. to 3 s. 2 d. per 1000 , and earn I 2s. to I 8s. per week. But the women exclusively make an inferior kind of cigar requiring less skill in the manufacture. In no cases, as I am informed, do men and women perform exactly the same work, although the difference between the grades appears to an outsider to be quite unconnected with any special fitness or ability.

So close, however, is the similarity in the tasks that it is possible that there is sometimes no essential difference between them. Miss Collet, for instance, found men and women doing the same kind of work in one small cigar factory in Leeds, but she goes on to add that 'the men are said to have a lighter touch than women, and to produce cigars of more equal quality than women as a rule.' 3 On

I I believe this is occasionally the case in London sweaters' dens; but this means that a few men are, by exception, doing women's work.

2 It may be convenient to recall that Miss Clara Collet, in her article on 'Women's Work in Leeds' in the Economic Journal for September 1891, stated that ' in the Jewish workshops the men machinists are paid a higher daily wage than the women, and the indifference with which the Jewish masters take on men or women at the different rates seems to show that women in the clothing trade are really being treated on equal terms with men, and that a substitution of men for women, although most improbable, is not inconceivable.'

3 'Women's Work in Leeds,' Economic Journal, September I891, p. 473. Nowhere in Leeds but in this cigar factory and in a Jewish (clothing) workshop did Miss Collet find men and women doing the same kind of work. 
the other hand, Miss Clementina Black has since informed me of an altogether exceptional case in London, in which female cigar-makers demanded and obtained a rise of wages apart from their male colleagues in the same establishment, some of whom now receive less than some of the women. The point requires further investigation, and it would be unsafe, in the meantime, to draw any conclusions, one way or another, from the facts yet recorded as to this industry.

Perhaps the clearest case of similar work is that of the Lancashire cotton-weavers, where men and women often perform exactly the same work side by side in the same shed, under practically the same Factory Act restrictions. Here the piece-work rates are the same for women as for men, and clever women often get through more work, and thus earn higher weekly wages than some of the men.

The following table, compiled from the Board of Trade return, shows that the average weekly earnings of the most highly skilled men and women cotton-weavers are, in the most important districts, nearly equal. ${ }^{1}$

Average Earnings (at piece-work), in a week of October I 886, of Cotton Cloth Four-loom Weavers

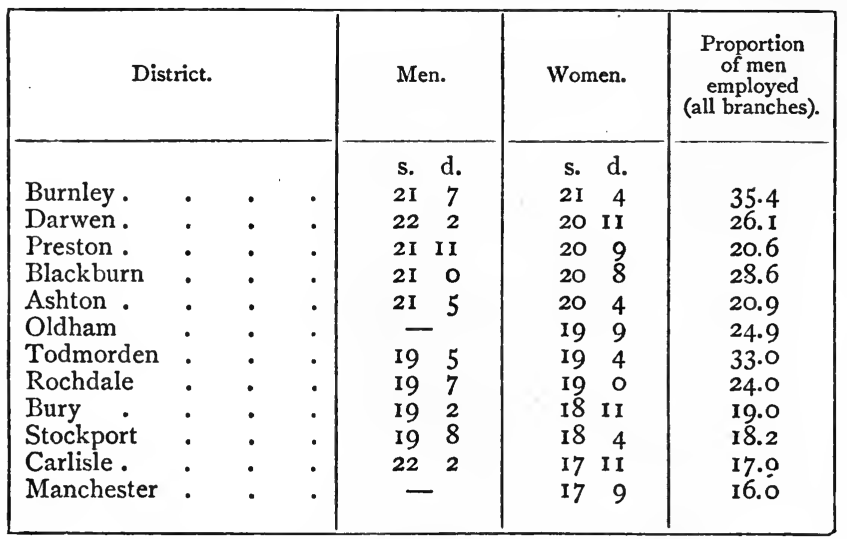

Compiled from pp. ix and $x$ of C. -5807 of 1889 .

1 It may be interesting to record that this equality of rates and equality of 
A similar equality of task wages appears to prevail in cotton-weaving in France. ${ }^{1}$ This is not often the case in cotton-spinning, where the women now seldom perform the same kind of work as the men, and where they receive lower wages. The following are the usual rates in Yorkshire cotton-spinning mills :-

\begin{tabular}{|llll|l|l|}
\hline & & & Men. & Women. \\
\hline Unskilled Operatives &. &. & I6s. to I8s. & I2s. \\
Half-Skilled . &. &. &. & 22s. to $25 \mathrm{~s}$. & I $5 \mathrm{~s}$. \\
Highly Skilled &. &. &. & 30s. to $35 \mathrm{~s}$. & 20s. \\
\hline
\end{tabular}

The mill-owner who supplied these figures added, 'If men had from any cause to be employed in the work which women now do, they would undoubtedly get higher wages, though they might. not do more or better work; the standard of their wages is higher.' But this is contradicted by another Yorkshire mill-owner, who says, "Should we employ men and women together in our "doubling," they would have to work "on piece" at the same rate, just as in our weaving-sheds.' The explanation of the discrepancy probably is that women and men are not actually employed at the same work in spinning, and that both the suppositions refer to imaginary cases.

Nor does the equality extend to other branches of the cotton industry, a fact clearly brought out by the following table :-

earnings prevailed among cotton workers as far back as 1824 , when cottonspinning machines were first worked by women in Glasgow. (Fifth Report of Select Committee on Artizans and Machinery, 1824, p. 525.)

1 Le Travail des Femmes au Dix-Nenvieme Siècle. P. Leroy-Beaulieu. 
Average Earnings, in a week of October 1886, of Operatives (other than Weavers) in the Cotton Manufacturing Industry in branches employing both Men and Women.

\begin{tabular}{|c|c|c|c|c|}
\hline & & & Men. & Women. \\
\hline Mixers' Assistants & & & $\begin{array}{ll}\text { s. } & \text { d. } \\
\text { I4 } & 9\end{array}$ & $\begin{array}{cc}\text { s. } & \text { d. } \\
\text { I I } & 2\end{array}$ \\
\hline Scutchers & . & . & 188 & I 3 \\
\hline Feeders & - & . & 169 & 120 \\
\hline Card Minders & . & . & 24 I0 & 10 5 \\
\hline Sweepers & & - & 156 & 9 I \\
\hline Jobbers (doubling) & & - & 180 & Io \\
\hline Doublers . & . & . & 160 & 120 \\
\hline Piecers. & . & . & 177 & 13 \\
\hline Beam-warpers & - & . & 25 & 18 \\
\hline Drawers-in . & - & - & 25 & I7 \\
\hline Twisters-in . & . & . & 209 & I 5 \\
\hline Cloth-lookers & . & . & 24 & II 0 \\
\hline Folders up . & - & - & 17 & IO \\
\hline Roller Coverers & . & $\cdot$ & 268 & 166 \\
\hline
\end{tabular}

Compiled from pp. I-6 of C. -5807 of I889.

Equality of piece-work rates is distinctly stated to be the invariable rule in the silk manufacture at Lyons. ${ }^{1}$ But in the latter case the women earn, on an average, only seventenths of the time wages of the men, because many of the looms require the exercise of a strength which tasks a woman's power to the utmost.

A similar state of things appears to prevail in England, where silk spinners and weavers employed by time earn practically equal wages, but women at work by the piece earn much less than men.

Weaving, indeed, appears to be nearly always paid at equal rates to men and women, whatever the material or locality. Thus in the manufacture of handkerchiefs, carried on in the counties of Armagh, Antrim, and Down, Ireland, the handloom weavers are three-fifths men and two-fifths women. The average weekly earnings of the men in 1885

1 L'Ouvriere. Jules Simon. Ch. iii. p. 33. 
were $7 \mathrm{~s}$. Iod., and those of the women $7 \mathrm{~s} .8 \mathrm{~d} .^{1} \quad$ Similar statistics may be given with regard to the weaving of woollens, worsteds, and fustians. ${ }^{2}$

Average Earnings, in a week of October 1886 , of Operatives in the Silk Manufacture in branches in which both Men and Women are employed.

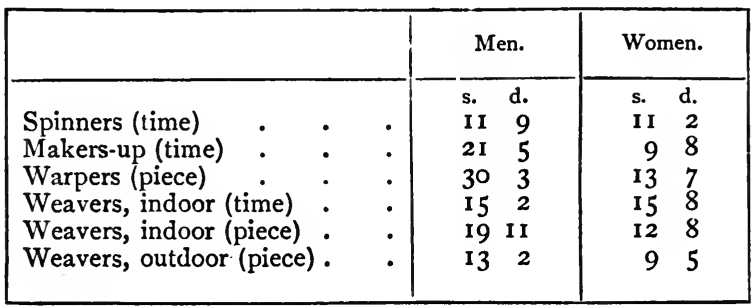

Compiled from C. $-6 \mathrm{r} 6 \mathrm{r}$ of $1890, \mathrm{pp} .23-25$.

Average Earnings (at piece-work), in a week of October I 886, of Power Loom Weavers (woollens)

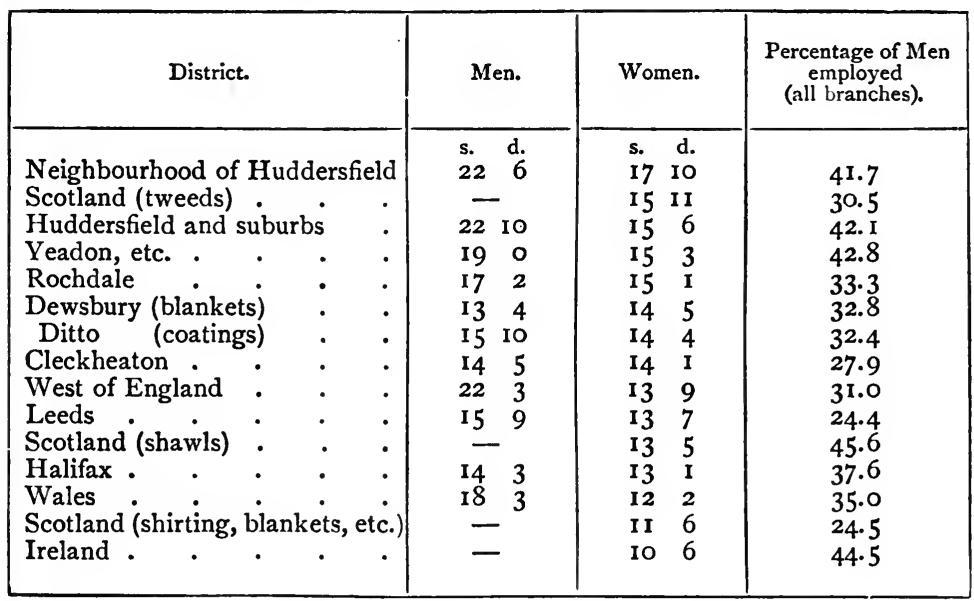

Compiled from pp. xiv and $\mathrm{xv}$ of $\mathrm{C} .-5807$ of 1889 .

1 P. 69 of C. -6161 of 1890.

2 Part of the inequality in earnings between men and women weavers, where 
Average Earnings (at piece-work), in a week of October 1886 , of Worsted Weavers

\begin{tabular}{|c|c|c|c|}
\hline District. & Men. & Women. & $\begin{array}{l}\text { Percentage of Men } \\
\text { employed } \\
\text { (all branches). }\end{array}$ \\
\hline $\begin{array}{l}\text { Keighley } \\
\text { Bradford } \\
\text { Halifax } \\
\text { Elsewhere in }\end{array}$ & $\begin{array}{lr}\text { s. } & \text { d. } \\
\text { 16 } & \text { II } \\
\text { I4 } & 7 \\
\text { 16 } & 4 \\
14 & 0\end{array}$ & $\begin{array}{lc}\text { s. } & \text { d. } \\
\text { I4 } & \text { I } \\
\text { I3 } & 9 \\
\text { I3 } & 6 \\
\text { I3 } & 4\end{array}$ & $\begin{array}{l}25.8 \\
18.7 \\
11.0 \\
23.7\end{array}$ \\
\hline
\end{tabular}

Compiled from p. xix of C. -5807 of 1889 .

Average Earnings (at piece-work), in a week of October 1886 , of Weavers of Fustians, Velvets, and Velveteens

\begin{tabular}{|c|c|c|c|c|c|c|}
\hline \multirow{2}{*}{$\begin{array}{c}\text { Number of } \\
\text { Looms. }\end{array}$} & \multicolumn{3}{|c|}{ Men. } & \multicolumn{3}{|c|}{ WOMEN. } \\
\hline & Maximum. & Minimum. & Average. & Maximum. & Minimum. & Average. \\
\hline 2 & s. d. & s. d. & $\begin{array}{ll}\text { s. } & \text { d. } \\
\text { I2 } & 0\end{array}$ & $\begin{array}{ll}\text { s. } & \text { d. } \\
\text { I2 } & 6\end{array}$ & $\begin{array}{ll}\text { s. } & \text { d. } \\
9 & 0\end{array}$ & $\begin{array}{ll}\text { s. } & \text { d. } \\
\text { II } & 6\end{array}$ \\
\hline 3 & 186 & I5 O & 166 & 186 & 13 & 171 \\
\hline 4 & 21 & 180 & 1910 & 210 & 14 & 1810 \\
\hline
\end{tabular}

Compiled from p. 65 of C. -5807 of 1889 .

I have been unable to ascertain whether the piece-work rates are the same for men and women weavers of linen, or fabrics of jute. In the former industry their weekly earnings are much inferior to those of men.

such exists, is due, I am informed, to the inability of the women to 'tune' or set their own looms. Special men are usually employed as 'tuners,' but the male weavers will often tune their own looms rather than lose time in waiting for the tuner. The women weavers have apparently never learnt this art, and hence must either wait or induce a male weaver to help them. See Industrial Democracy, part ii. ch. $x$. sec. 4 . 
Average Earnings, in a week of October 1886, of Operatives in the Linen Manufacture in branches in which both Men and Women are employed.

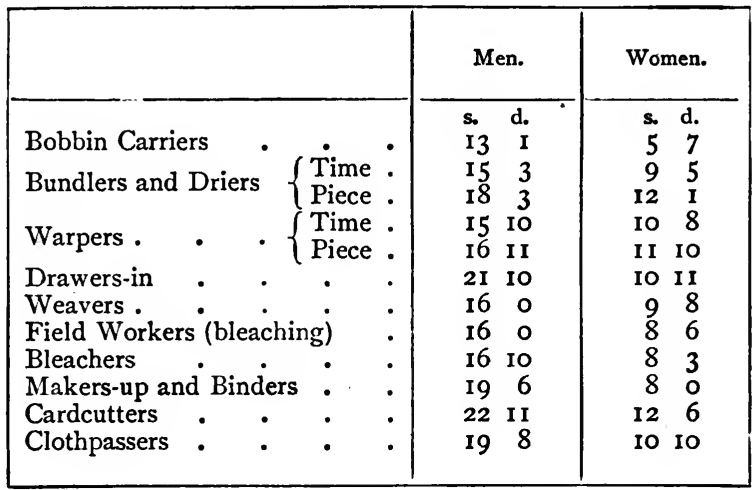

Compiled from pp. $130-32$ of C. -5807 of 1889 .

This is also the case in the branches of the woollen and worsted industries other than weaving.

Average Earnings, in a week of October I 886, of Operatives (other than Weavers) in the Woollen Industry in branches in which both Men and Women are employed.

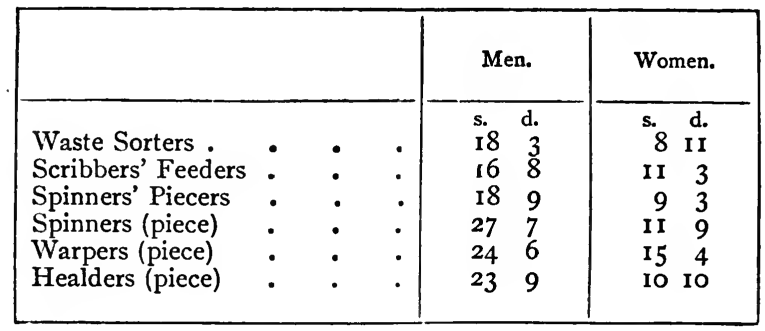

Compiled from pp. $66-68$ of C. -5807 of 1889 . 
Average Earnings, in a week of October I 886, of Operatives (other than Weavers) in the Worsted Trade in branches in which both Men and Women are employed.

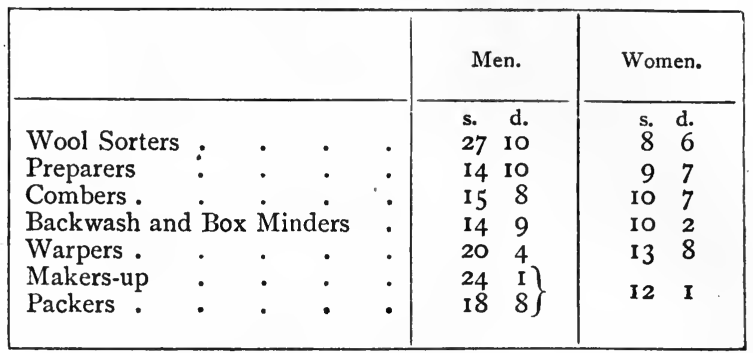

Compiled from pp. I1 14 - I 15 of C. -5807 of $1889 .^{1}$

The men and women employed at a world-renowned manufactory of 'frilling' in Warwickshire are often engaged on the same work, and their piece-work rates are then the same. A similar report comes from the carpet-weaving industry.

In fustian cutting (velveteen) men and women do precisely the same work, and the piece-work rates are identical : women earn nearly as much as men, but not quite, the men gaining the advantage of their superior strength and endurance.

I am informed, although the statement seems incredible, that in this industry a man can only earn I 3 s. to I 4s. per week by cutting two full 'pieces,' and that this involves a daily walk of I 5 or 20 miles, not to mention the other muscular exertion required. No machinery is employed, and each operative works independently by hand. The women's hours are restricted by law, but this has apparently made no difference to their piece-work rates, and they do not find it any disadvantage. The Trade Union includes both sexes.

1 Other statistics on Women's wages are given in the admirable Report by Miss Collet on the Statistics of Employment of Women and Girls, C.-7564, published by the Labour Department of the Board of Trade in 1894 . 
It should be noted that in all these instances of equal remuneration for equal work, both sexes are practically equally restricted by the Factory Acts; there are strong Trade Unions for both; both sexes have been at work in the industry for a long period; and the influence of competition appears to be very little checked by economic friction of any kind. Moreover, although women make as good weavers as men, and are paid at equal rates, they are never promoted to any higher-paid work. The overlookers' places are reserved exclusively for men, probably because, even if women were found fit for them, the male operatives would not accept a woman supervisor.

It may also be suggested that in these industries, as in most other cases where it is customary for men and women to work together, neither man nor woman earns as much as an equally skilled worker in a trade where men alone work, and the result is that husband and wife have both to work for little more than the wages of an engineer or an ironmoulder, whose wife seldom earns money. The economic unit is the family, and to the family income husband and wife make, in Lancashire, often equal contributions.

On the other hand, women compositors in London receive uniformly lower piece-work rates than men obtain for exactly similar work. Omitting minor details, the general rule is that, for setting up ' Ioo० ens,' for work, that is to say, of precisely the same quantity and quality, the Trade Unionist gets $8 \frac{1}{2} \mathrm{~d}$., the non-unionist man about $7 \frac{1}{2} \mathrm{~d}$., and the woman only $5 \frac{1}{2} \mathrm{~d}$. $^{1}$

1 Women compositors in London do not number more than 300. They earn higher wages than women receive in other trades, but various causes keep their number down. Only about a dozen firms employ more than three or four women, the greatest number in one establishment being twenty. The number is made up by firms employing one or two women. The London Society of Compositors passed a resolution in 1887 admitting women to membership provided they earned the Trade Union rate (see The History of Trade Unionism (London, 1894), and Industrial Democracy, by Sidney and Beatrice Webb (London, 1898), vol. ii. p. 499 ; but none satisfy this condition, and 'Society Houses' can therefore only employ women under exceptional circumstances. 
This inequality has not always existed. The firm which first introduced women compositors (McCorquodale, Newtonle-Willows, Lancashire), forty-four years ago, and worked them under the same rules as the men, paid them at the same rate, being that then current, viz. $4 \frac{1}{2} \mathrm{~d}$. per ' I 000 ens.'

This fact, and the obvious disadvantage under which women compositors now labour in being forbidden to work at night, on Saturday afternoons or Sundays, at the mealtimes or for unlimited hours, would lead us to suppose that this restrictive legislation was an adequate cause of their lower wages. But I am informed that in Paris, where women compositors are not subject to these disabilities, their

One woman only has joined the society. The following were the actual rates of wages paid in July I89I, in the principal London firms employing women :-

\begin{tabular}{|c|c|c|}
\hline Firm. & On Time, per hour. & On Piece, per rooo ens. \\
\hline $\begin{array}{l}\text { No. } 1 \\
\text { No. } 2 \\
\text { No. } 3 \\
\text { No. } 4 \\
\text { No. } 5 \\
\text { No. } 6 \\
\text { No. } 7 \\
\text { No. } 8 \\
\text { No. } 9\end{array}$ & $\begin{array}{l}5 \mathrm{~d} . \\
6 \\
5 \\
6 \\
6 \\
\text { None } \\
5 \frac{1}{2} \\
5 \frac{1}{2} \\
\text { None }\end{array}$ & $\begin{array}{l}5 \frac{1}{2} \mathrm{~d} . \\
6 \\
5 \\
5 \frac{1}{2} \\
5 \frac{1}{2} \\
5 \frac{1}{2} \\
5^{\frac{1}{2}} \\
5^{\frac{1}{2}} \\
5^{\frac{1}{2}}\end{array}$ \\
\hline $\begin{array}{l}\text { Rates for men in the same } \\
\text { firms }\end{array}$ & $7 \frac{1}{2}$ & $7 \frac{1}{2}$ \\
\hline Trade Union Rates . & ' Not less than 8 d. to $8 \frac{1}{2} \mathrm{~d}$.' & $\begin{array}{l}7 \mathrm{~d} \text {. to Is. so as to average } \\
\text { not less than } 8 \frac{1}{2} \mathrm{~d} \text {. }\end{array}$ \\
\hline
\end{tabular}

Women compositors in Edinburgh receive little more than a third of the recognised Trade Union rates; their introduction did much to break up the general strike of $1872-3$, and is said to have completely revolutionised the trade in that city. (P. I 25 of Third Report on Trade Unions, C. -5808 of 1889 .)

They are also employed in two newspaper offices at Warrington, and in large book-printing establishments at Aylesbury and Redhill where they receive less than half the Trade Union rate per 1000. A small number of girls (not more than fifty in all) are employed in some towns for the work of distributing the type where a certain kind of composing machine is used; but in no such case do they manipulate the composition, which the men retain for themselves. For further particulars as to women compositors, see the article by Amy Linnett, Economic Review, January I892 ; and Industrial Democracy, vol. ii. ch. x. sec. 4. 
piece-work rates are, nevertheless, much below those of men. This is also the case at Capetown where no factory law exists. ${ }^{1}$ In neither case are they protected by a Trade Union.

The latter remark applies to practically all my remaining instances.

In salt-making women often perform work elsewhere done by men, and they are said to work better in the heat of stoves than the men; and to be more 'neat-handed' in 'tapping the squares.' But they do less work, two men taking the places of three women. The men get $£_{\mathrm{I}}$ a week, the women only IOS., so that it would seem that the women were paid not only lower 'time wages,' but also lower 'task wages' than the men.

In brush-making the men and women do different work, the men bore the holes, and the women, at a lower wage, put in the bristles. But latterly, women have in some cases been put on to do the boring by machinery, at a lower rate of wage than the men. Except in East London, and that only recently, the women have no Trade Union, and the men refuse them admission to theirs, professedly on the ground that the women cannot obtain the Union scale of piece-work rates, which is strictly maintained. The men state that they do not object to women working at 'drawing' (putting in ordinary bristles), but they will not allow them to do the boring or to 'work at pan' (fastening in the bristles by pitch), on the plea that their introduction would merely be used to reduce wages. It may, however, be observed that this line of division between men's and women's work is not so much a scientific frontier as an assertion of the existing line of demarcation, which is doubtless due to historical reasons, and which leaves the higherpaid work to the men. ${ }^{2}$

In many cases work now done by women was formerly I89I.

1 Report of Select Committee of Cape Legislature upon Colonial Industries,

2 On the remarkable change of policy among Trade Unions with regard to the policy to be pursued towards women competitors, see Industrial Democracy, vol. ii. ch. $x$. sec. 4 . 
performed by men, and the women almost invariably receive less than the men did. Sometimes the substitution has been occasioned by the introduction of new machinery. When the machine known as the 'roundabout' began to be used for banknote engraving, young men were at first employed as 'layers on,' at I 8s. per week. Now women do this work for I 2 s. per week, exactly as well and as fast as the men.

In other cases the substitution of women for men has taken place without any change in the industrial process, merely by the effect of the industrial 'survival of the less fit.' In a factory of tins for preserved food, men were formerly employed in a certain process of closing the tins at from I 5 s. to 20 s. per week. Women now do this work less quickly, but they receive only 7 s. to I Os. per week. Similarly women now often stamp the gilt lettering on book covers. Men formerly worked with great efficiency the automatic steam-press which performs this operation, and earned, at piece-work, as much as $35 \mathrm{~s}$. a week. Women, managing the machine with less efficiency, now do as good work, but less of it, for a fixed wage of I 2 s. a week.

In umbrella-making, too, women are being put on to do, at a lower rate of pay, work hitherto done by men. There is a separate Trade Union for each sex. ${ }^{1}$

In rope-making women have, of recent years, been substituted for men, in the 'heavy' work, which is now largely done with the aid of machinery. They receive lower wages than the men did, but the change of process deprives the instance of significance. But when, in I 89I, the women in London struck for higher wages, the employers at first got their work done by boys at slightly higher rates. The boys then refused to continue at those wages, and men had to be employed at a man's normal wage, which was far in excess of what the women had been earning for'exactly the

1 A few women French polishers in London are paid by the piece, and receive the same rates as men (but do not do so much work). But usually the women polish the smaller articles of furniture, and men the larger. 
same work. Here the different 'market' rates of men's and women's wages seem to have been unconnected with their respective proficiency in this particular work.

Sometimes quantity remains the same, but quality suffers. One part of the saddle is known as the 'pad top.' For stitching and other work in connection with this, men receive $4 \mathrm{~s}$. each. In one large saddler's women were introduced who did this work equally quickly for 2 s. 3 d., but did it, the men said, less well.

One instance to the contrary effect must now be given. The stitching of the serge lining to a saddle is not done by the actual saddle-maker, but is put out by him, and paid for, in London, at the fixed rate of $6 \mathrm{~d}$. Men formerly did this work with somewhat clumsy fingers, and earned only 25 s. a week. Women are now generally employed, who perform the work equally well, and about 40 per cent quicker. Although these women earn $35 \mathrm{~s}$. a week, the customary rate of $6 \mathrm{~d}$. had, I was informed in I $89 \mathrm{I}$, not been reduced. It should be noted that the employers and paymasters are, in this case, themselves journeymen wage-earners.

Women employed in agriculture receive, by an almost invariable custom, lower wages per week than men, and the same is true of grown lads fully equal to doing a man's work. But (in some parts of S.E. England at any rate) when, in the stress of harvesting, competition obtains free play, and labourers are employed at piece-work rates, men, women, and children are paid equal rates for the task performed. A similar state of things prevails in the East of Scotland, especially in turnip-hoeing.

I find it difficult to draw any general conclusion from the foregoing facts. But they suggest to me that the frequent inferiority of women's earnings in manual work is due, in the main, to a general but not invariable inferiority of productive power, usually in quantity, sometimes in quality, and nearly always in nett advantageousness to the employer. Founded on this general inferiority, and perhaps on the lower standard of life of women, the custom of paying lower 
wages to women exercises great influence even where these conditions do not exist. This custom is intensified by the influence of 'make weights,' the assistance received by so many women workers from parents, husbands, or lovers.

Custom is presumably less powerful in regulating wages in the United States than in England, and in the United States the proportion which the average earnings of women in manufacturing industry bear to those of men, is, as we have seen, considerably higher than in this country. ${ }^{1}$

Where competition rates of wages prevail, and especially where the women are protected by strong Trade Unions, they often earn wages equal to those of men for equal work. ${ }^{2}$

\section{II.-Routine Mental Work}

Turning, now, to occupations usually considered of higher status than manual labour, we find more instances of women performing work of the same kind as men, but it is less easy to be sure that it is equal to men's work in quantity and quality. Women's earnings in these occupations are invariably less than men's. Women typewriters employed by the Government receive, to begin with, only $14 \mathrm{~s}$. per week, the reason given being that this is the market rate for women typewriters, though not for men. In the United States, on the other hand, where competition has perhaps freer play, women typewriters receive wages the same as men typewriters. Women clerks in the Post Office perform exactly the same duties as some of the men clerks. In the Savings Bank Department they do, unit for unit, precisely the same amount of work. In the ledger work, on which both men and women are still employed, the women are said to do the work 'much better, more carefully, more neatly; they are

1 Compare the facts cited elsewhere as to women typewriters in the United States generally; and women teachers in Wyoming.

2 The attraction to the employer of women's labour is often less in its actual cheapness than in its 'docility,' and want of combination. 'Women strike less,' says one. A similar fact is recorded as to the employment of the negro in manufacturing industries in the 'New South' (United States). 
The men and women in each class do, as nearly as possible, the same work. But the women's hours are often arranged with more consideration for their health and comfort, and, in particular, they do no night duty, of which there is a great deal.

This is the case also with the telegraphists in the head office, particulars of whom are given below :-

\begin{tabular}{|c|c|c|c|c|}
\hline & \multicolumn{2}{|r|}{ MEN. } & \multicolumn{2}{|r|}{ WOMEN. } \\
\hline & Number. & Wages. & Number. & Wages. \\
\hline First Class . & $44 I$ & $\begin{array}{c}\text { Per annum. } \\
£ \text { Ioo, by } £ 6 \text {, to } £ \text { 160 }\end{array}$ & 230 & $\begin{array}{c}\text { Per week. } \\
\text { 30s., by Is. 6d., to } 38 \text { s. }\end{array}$ \\
\hline Second Class & I 149 & $£ 45$, by $£ 6$, to $£$ i 10 & 521 & 2 Is. $6 \mathrm{~d}$. to $30 \mathrm{~s}$. \\
\hline
\end{tabular}

The amount of time lost from sickness is undoubtedly greater in the case of women than in that of men, but the following tables relating to the Post Office show that this is not an invariable rule. ${ }^{1}$

1 Compiled from official statistics for 1889 , a year of more than average sickness. But the influenza probably affected both sexes alike. These tables have been criticised as though they had been put forward to prove that the women were as healthy as the men. What they appear to indicate is just the reverse, and the fact that some extra consideration is shown to the women in the way of arrangement of hours, overtime, etc., only strengthens this inference. 


\section{Women's Wages}

\section{Principal Offices}

Average amount of Sickness in days per head of Male and Female Officers during r889, in Offices where both Males and Females are employed.

\begin{tabular}{|c|c|c|c|c|c|c|c|}
\hline \multicolumn{4}{|c|}{ "Clenks. } & \multicolumn{4}{|c|}{ Telegraphists. } \\
\hline Office. & Male. & Female. & $\begin{array}{c}\text { Females } \\
\text { com- } \\
\text { pared } \\
\text { with } \\
\text { Males. }\end{array}$ & Office. & Male. & Female.t & $\begin{array}{c}\text { Females } \\
\text { com- } \\
\text { pared } \\
\text { with } \\
\text { Males. }\end{array}$ \\
\hline $\begin{array}{l}\text { S.W. London } \\
\text { Edinburgh. } \\
\text { Manchester } \\
\text { Birmingham } \\
\text { Central Savings } \\
\text { Bank } \\
\text { Liverpool : } \\
\text { Glasgow : } \\
\text { Receiver and Ac- } \\
\text { countant-Gene- } \\
\text { ral's Office, } \\
\text { London : } \\
\text { Dublin : }\end{array}$ & $\begin{array}{l}3.3 \\
7.4 \\
4.2 \\
8.0 \\
\\
7.4 \\
1.3 \\
6.4\end{array}$ & $\begin{array}{r}0 \\
4.0 \\
5.0 \\
6.0 \\
8.9 \\
9.7 \\
11.8\end{array}$ & $\begin{array}{l}-3.3 \\
-3.4 \\
+0.8 \\
-\quad 2.0 \\
+1.5 \\
+8.4 \\
+5.4 \\
\\
+4.1 \\
+17.5\end{array}$ & $\begin{array}{l}\text { Wandsworth } \\
\text { N.W. London } \\
\text { Glasgow } \\
\text { W. London } \\
\text { Norwood : } \\
\text { E.C. London } \\
\text { W.C. London } \\
\text { Central Telegraph } \\
\text { Office } \\
\text { Edinburgh. } \\
\text { Manchester } \\
\text { N. London } \\
\text { S.E. London } \\
\text { S.W. London } \\
\text { Paddington } \\
\text { Liverpool : } \\
\text { Birmingham } \\
\text { Returned Letter } \\
\text { Office : } \\
\text { Dublin : }\end{array}$ & \begin{tabular}{r}
\multicolumn{1}{c}{0} \\
4.8 \\
5.8 \\
7.5 \\
$* 23.5$ \\
6.8 \\
2.8 \\
\\
7.9 \\
6.3 \\
11.5 \\
4.2 \\
3.7 \\
7.9 \\
3.9 \\
8.5 \\
9.3 \\
$* 13.3$ \\
10.6
\end{tabular} & $\begin{array}{r}2.0 \\
3.4 \\
6.7 \\
6.9 \\
6.9 \\
9.2 \\
9.7 \\
\\
11.6 \\
{ }^{*} 12.3 \\
{ }^{*}{ }_{1} 14.3 \\
{ }^{*} 14.7 \\
{ }^{*}{ }_{1} 5.0 \\
{ }^{*} 15.1 \\
{ }^{*} 15.7 \\
{ }^{*}{ }_{1} 5.9 \\
{ }^{*} 18.8 \\
{ }^{*} 22.2 \\
{ }^{*} 24.4\end{array}$ & $\begin{array}{l}+2.0 \\
-1.4 \\
+0.9 \\
-0.6 \\
-16.6 \\
+2.4 \\
+6.9 \\
+3.7 \\
+6.0 \\
+2.8 \\
+10.5 \\
+11.3 \\
+7.2 \\
+11.8 \\
+7.4 \\
+9.5 \\
+8.9 \\
+13.8\end{array}$ \\
\hline
\end{tabular}

* High rate due to lengthened absence of one or two officers.

$\uparrow$ Including counter-women.

On the whole, these imperfect statistics, which are the less trustworthy in that the number of women concerned is much smaller than that of the men, bear out the popular impression that women's labour is subject to more frequent interruption from illness than men's. But the Post Office and the Treasury are certainly under the belief that, notwithstanding this fact, they are buying their women labour at a lower net rate than men's. And this is especially the case with regard to the routine clerical work of the indoor clerks where no night duty is required. 


\section{Large Provincial Offices (Sorting Clerks and Telegraphists)}

Average days absence from Sickness per head during 1889 in Towns where both Males and Females are employed.

\begin{tabular}{|c|c|c|c|c|c|}
\hline \multicolumn{3}{|c|}{ Office. } & \multirow{2}{*}{$\begin{array}{c}\text { Males. } \\
0.7\end{array}$} & \multirow{2}{*}{$\begin{array}{c}\text { Females. } \\
0\end{array}$} & \multirow{2}{*}{$\begin{array}{c}\begin{array}{c}\text { Females com- } \\
\text { pared with } \\
\text { Males. }\end{array} \\
-0.7\end{array}$} \\
\hline Halifax . & & - & & & \\
\hline Bradford, Yo & rks & . & 3.2 & 0 & -3.2 \\
\hline Birkenhead & . & . & 3.7 & o & -3.7 \\
\hline Brighton & . & - & 4.1 & 0 & -4.1 \\
\hline Exeter . & . & . & 2.0 & 0.2 & -1.8 \\
\hline Plymouth & . & - & 6.2 & 0.3 & -5.9 \\
\hline Chester . & & • & 6.4 & 0.7 & -5.7 \\
\hline Burton-on-Tr & rent & - & 0.6 & I.O & +0.4 \\
\hline Cheltenham & . & - & 2.6 & 3.1 & +0.5 \\
\hline Dundee. & . & • & 8.8 & $3 \cdot 3$ & -5.5 \\
\hline Shrewsbury & - & • & 4.4 & 3.8 & -0.6 \\
\hline Carlisle . & - & - & 1.8 & 5.7 & +3.9 \\
\hline Southampton & 1. & & 5.9 & 6.0 & $+0 . I$ \\
\hline Greenock & . & • & 10.3 & 9.0 & -1.3 \\
\hline Swansea & $\cdot$ & - & 3.2 & 9.8 & +6.6 \\
\hline Wolverhampt & ton & , & 6.2 & II.7 & +5.5 \\
\hline Cardiff $\cdot$ & . & - & 6.4 & II. 7 & +5.3 \\
\hline Huddersfield & - & • & 1.4 & ${ }^{*} 12.2$ & +10.8 \\
\hline Hull . & . & . & 4.2 & ${ }^{*} 12.4$ & +8.2 \\
\hline Aberdeen & - & - & $4 \cdot 3$ & * 12.6 & +8.3 \\
\hline Belfast • & - & - & 6.3 & ${ }^{*} 13.0$ & +6.7 \\
\hline Portsmouth & - & - & 4.7 & ${ }^{*} 14.8$ & + IO. I \\
\hline Leeds . & - & • & 7.6 & ${ }^{*}$ I 5.1 & +7.5 \\
\hline Bolton . & & . & 3.5 & ${ }^{*} 15.3$ & +11.8 \\
\hline Newcastle-on & -Tyne & e & 7.0 & ${ }^{*} 15.4$ & +7.6 \\
\hline Cork . & . & . & 5.9 & ${ }^{*} \mathrm{I} 6.8$ & +10.9 \\
\hline Bristol . & . & - & 8.9 & ${ }^{*} 17.1$ & +8.2 \\
\hline Nottingham & . & . & 4.0 & ${ }^{*} 22.5$ & +18.5 \\
\hline York . & - & - & $5 \cdot 5$ & ${ }^{*} 38.3$ & +32.8 \\
\hline
\end{tabular}

* High rate due to lengthened absence of one or two officers. With regard to this table it must be borne in mind that the women do no night duty.

The Prudential Life Assurance Company began, in I 872 , to substitute women clerks for the lower grades of men clerks. This experiment has proved so successful that in 1891243 , and in 1898 over 300 , ladies were employed exclusively on clerical work of a routine character (copying letters, and filling up forms and schedules). This work they perform, I am assured, rather better and more rapidly than 
men. The salaries paid to them for the same number of hours' work per day as the men were in I89 I as follows, and I learn that substantially the same scale is (1898) now in force :-

\begin{tabular}{|c|c|c|c|c|c|}
\hline $\begin{array}{c}\text { On Entering, } \\
\text { age 17 to 25. }\end{array}$ & $\begin{array}{c}\text { Second } \\
\text { Year. }\end{array}$ & $\begin{array}{c}\text { Third } \\
\text { Year. }\end{array}$ & $\begin{array}{c}\text { On } \\
\text { Promotion. }\end{array}$ & $\begin{array}{c}\text { 12 Heads of } \\
\text { Divisions. }\end{array}$ & I Matron. \\
\hline$£ 32$ & $£ 42$ & $£ 52$ & $£ 60$ & $£ 95$ & $£$ II 5 \\
\hline
\end{tabular}

These salaries, which are perhaps less than half what would have to be paid to men for similar work, have been found sufficient to attract an overwhelming number of applicants - a fact to be accounted for, in some degree, by the appointments being known to be restricted to the daughters of professional men. For women's work, the 'gentility' of the occupation is still accepted as part payment. Hence women clerks are cheap to the Prudential, in spite of their being absent from sickness, as I was informed by the manager in $\mathrm{I} 89 \mathrm{I}$, more than twice as much as the men. ${ }^{1}$ Moreover, it has been found impossible to entrust them with any but the merest routine work, and this, it must be remembered, is a drawback to their 'nett advantageousness' to the employer. His higher staff must be recruited, and he would therefore prefer, other things being equal, to fill his lower ranks with workers from whom he could select superior individuals for promotion. Moreover, although men can be set over women, women cannot yet often be set over men, even if they are found to possess the governing faculty.

It is, perhaps, partly for the reason of 'gentility' that women teachers almost invariably receive lower salaries than men teachers. The Education Department Report for

1 This, it was suggested, was due not so much to serious illnesses as tc slight indispositions, in which the women are said to show 'less pluck' than the men in sticking to their work. But the men's work is their life-career; the women's a mere prelude to matrimony, and often only a source of pocket-money. 
I 889-90 gives the average for men teachers throughout England and Wales as £II9 as compared with $£_{94}$ in I 870, and that for women teachers at $£ 75$ as compared with $£ 57$ in I 870 . I 556 male teachers out of 17,449 had attained $£ 200$ a year, or nearly 9 per cent; whereas only 380 female teachers out of 26, 139 reached that level, or about $\mathrm{I} \frac{1}{2}$ per cent.

The average salary of 320 head masters under the London School Board in I890-9I (new scale) was £274; that of 653 head mistresses, £ig6.

Leaving out of account the more responsible positions which are most frequently given to men, the salaries of assistant teachers are habitually fixed, as the following tables will show, lower than those of men of a corresponding class :-

\section{Scale of Salaries for Assistant Teachers under the Reading School Board (I 89I)}

\begin{tabular}{|c|c|c|c|c|}
\hline & & $\begin{array}{l}\text { First } \\
\text { Year. }\end{array}$ & $\begin{array}{l}\text { Second } \\
\text { Year. }\end{array}$ & $\begin{array}{l}\text { Third } \\
\text { and } \\
\text { Subse- } \\
\text { quent } \\
\text { Years. }\end{array}$ \\
\hline $\left.\begin{array}{c}\text { Assistants holding Certificates } \\
\text { not lower than 2nd Class } .\end{array}\right\}$ & $\begin{array}{l}\text { Males } \\
\text { Females }\end{array}$ & $\begin{array}{c}£ \\
70 \\
60\end{array}$ & $\begin{array}{c}£ \\
75 \\
65\end{array}$ & $\begin{array}{l}6 \\
80 \\
70\end{array}$ \\
\hline $\left.\begin{array}{r}\text { Assistants who have not passed } \\
\text { the Queen's Scholarship Ex- } \\
\text { amination; or were placed } \\
\text { lowerthan in the 2nd Division }\end{array}\right\}$ & $\begin{array}{l}\text { Males } \\
\text { Females }\end{array}$ & $\begin{array}{l}45 \\
40\end{array}$ & $\begin{array}{l}50 \\
45\end{array}$ & $\begin{array}{l}55 \\
50\end{array}$ \\
\hline $\left.\begin{array}{c}\text { Assistants who have passed the } \\
\text { Queen's Scholarship Exam- } \\
\text { ination in the 2nd or Higher } \\
\text { Division of the List . }\end{array}\right\}$ & $\begin{array}{l}\text { Males } \\
\text { Females }\end{array}$ & $\begin{array}{l}55 \\
50\end{array}$ & $\begin{array}{l}60 \\
55\end{array}$ & $\begin{array}{l}65 \\
60\end{array}$ \\
\hline
\end{tabular}




\section{Primary Schools in Edinburgh (1890)-(23 Board Schools)}

(Taken from Edinburgh School Board Directory, 1890.-Offices of the School Board, Castle Terrace, Edinburgh.)

Men.

Head Master, $£ 320$ to $£ 420$ (omitting one of $£ 290$ ).

First Assistant, £130 to £200 (most over $£$ i 50 ).

Assistants $(a), £ 85$ to $£$ I 20 (nearly half (120).

Assistants (b), $£ 85$ to $£$ i 20 (more than half have over $£$ IOO).

Assistants (c), $£ 85$ to $£$ IO7 (chiefly $£ 90$ or $£$ IOo).

Singing Master, $£ 50$ to $£ 80 \quad(\mathscr{5} 50$ usually; five to seven hours per week).

\section{Women.}

Women not appointed.

First Assistant (only three instances; $£ 200$ in each case).

Assistants $(a), £ 65$ to $£$ Ioo (half have $£ 90$ to $f$ roo).

Assistants (b), $£ 65$ to $£$ roo (about half have $£ 80$ ).

Assistants (c), $£ 65$ to $£ 89$ (half have $\notin 75$ to $f 80$ ).

Infant School Mistress, $£$ r 30 to $£ 200$.

Assistants $(a), £ 65$ to $£ 100$ (more than half, $£$ I 00 ).

Assistants $(b), £ 40$ to $£$ Ioo (more than half have over $£ 70$ ).

Sewing Mistress, $£ 70$ to $£$ Ioo (more than half have over $£ 90$ ).

Assistant Mistress, $£ 15$ to $£ 20$ (mostly Ł20).

In 1898 , the School Board for London paid its teachers on the following scale :-

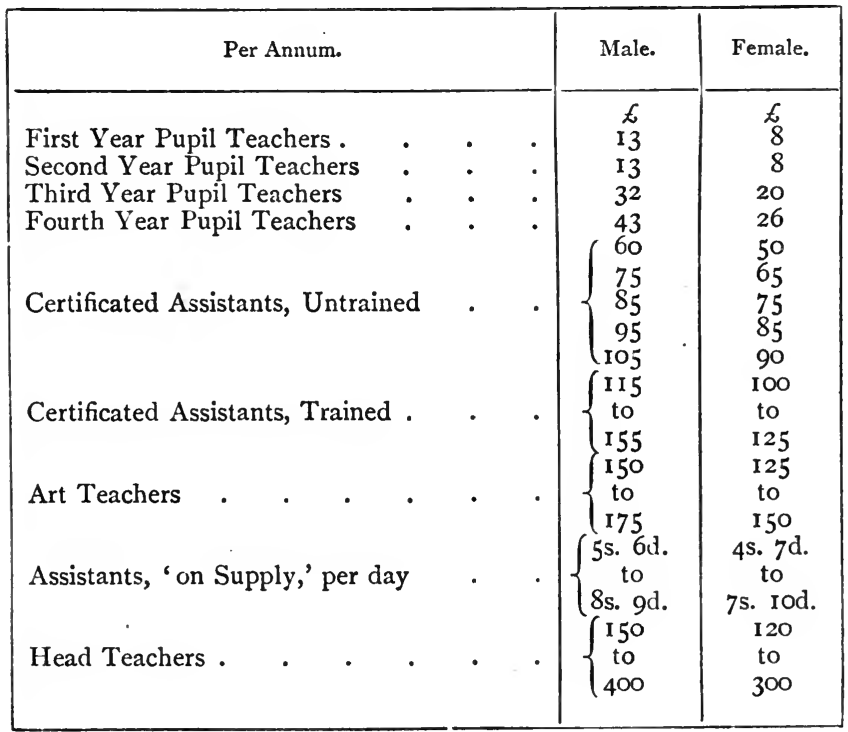


A similar inferiority in the wages of women teachers exists in secondary schools, although I am informed that the difference is less than it was, a result, in great measure, of the example of the Girls' Public Day School Company. But teachers in girls' schools still receive less than teachers in boys' schools.

\section{Rates of Pay of Teachers in Edinburgh Secondary Schools}

Merchant Company's Schools in Edinburgh (from their Report published 1890, April).

\begin{tabular}{|c|c|c|c|c|}
\hline \multirow{2}{*}{ SchoоLs } & \multicolumn{2}{|c|}{ NUMBER. } & \multicolumn{2}{|c|}{ SALARIES. } \\
\hline & Men. & Women. & Men. & Women. \\
\hline $\begin{array}{l}\text { George Watson's Boys' School . } \\
\text { Daniel Stewart's Boys' School . } \\
\text { Edinburgh Ladies' College (Queen Street) } \\
\text { George Watson's Ladies' College (George Square) }\end{array}$ & $\begin{array}{r}30 \\
17 \\
7 \\
4\end{array}$ & $\begin{array}{r}10 \\
4 \\
14 \\
19\end{array}$ & $\begin{array}{l}\qquad \\
\qquad \\
100 \text { to } 400 \\
\text { IOo to } 400 \\
\text { I } 10 \text { to } 300 \\
\text { I } 10 \text { to } 300\end{array}$ & $\begin{array}{l}6 \\
80 \text { to } 105 \\
80 \text { to } 105 \\
80 \text { to } 105 \\
60 \text { to } 120\end{array}$ \\
\hline $\begin{array}{c}\text { James Gillespie's Schools (mixed boys and } \\
\text { girls) }\end{array}$ & $\begin{array}{c}5 \text { for } \\
\text { standard } \\
\text { V. \& VI. }\end{array}$ & \} $\begin{array}{l}28 \\
\text { I.to V. }\end{array}$ & 94 to 109 & 40 to 106 \\
\hline
\end{tabular}

Men.
Three highest Salaries other than

Head Masters

English and Modern Languages

Highest Salaries of 'Class $\left\{\begin{array}{l}250 \\ 130\end{array}\right.$

'Teachers'

Two lowest Salaries . $\quad\left\{\begin{array}{r}115 \\ 79 \\ 69\end{array}\right.$
Women.

6
Lady Superintendent $\cdot\left\{\begin{array}{l}200 \\ 150\end{array}\right.$

English, French, and German Ioo Highest Salaries of 'Class $\begin{cases}76 & \mathrm{I} 6 \mathrm{~s} . \\ 71 & \mathrm{I} 6 \mathrm{~s} .\end{cases}$ Teachers'

60

$5^{8}$

78 Teachers and Pupil-governesses, 620 to $£ 47$.

The work of teaching girls is, I presume, quite analogous to that of teaching boys, and judging from the percentage of passes, is, in the elementary schools at any rate, at least as efficiently performed. Moreover in the lower standards, where boys and girls are mixed, it is often a matter of chance whether a male or a female teacher is employed.

It must, however, be stated that although men and women teachers may perform exactly equivalent work, or 
even the same tasks, and perform them with equal result, yet their scholastic attainments are seldom equal. The examinations for women teachers are, on the whole, slightly less difficult than those for men; the women, too, are said not to take as great an interest in improving their qualifications, and are less frequently found to be competent to teach subjects not in their minimum curriculum. Thus, when the London School Board decided in 1889 to divide the teachers of its evening classes into two grades, the lower comprising those able to teach only elementary subjects, and the other including those competent to instruct in French, shorthand, etc., it was found that far more men than women entered the higher grade.

In the United States, where women teachers often alternate with men in the same school, I am informed that the women habitually receive lower salaries than the men, the difference being greatest in the South, less in the Northeast, still less in the West, and disappearing altogether in the State of Wyoming, where (coincident with the right of women to vote) men and women teachers receive equal salaries for equal work. ${ }^{1}$ This seems to indicate that custom (again aided by the lower standard of life and the dependent position of women) has much to do with the inferiority of their salaries elsewhere in this class of work. ${ }^{2}$

\section{III.-ARTISTIC WORK}

Here we enter on a new field, in which I have no facts. But it is a matter of common observation that, in many

1 Sec. 9 of Wyoming School Act; see The Working of Woman Suffrage in Wyoming, by the Hon. Horace Plunkett (Fortnightly Review, May 1890).

2 The subject of teachers' salaries has, since $189 \mathrm{I}$, received much attention. The student should consult the Education Department's volume of Special Reports for 1896-97, and its Annual Report for the same year; the corresponding Annual Reports of the Scotch and Irish Education Departments; the Secondary Education Commission Report, 1895, vols. i. and iv.; The Education of Girls and Women in Great Britain by Miss Bremner (London, 1897); and Methods of Education in the United States by Miss Alice Zimmern (London, I894). 
grades of work connected with 'the arts,' there is no general inferiority in women's earnings compared with those of men. Indeed it is probable that in some cases women obtain higher remuneration than men, merely because they are women. Actresses and female singers and dancers often earn more than their male colleagues. It is difficult to estimate how far this is to be ascribed to the monopoly value which still attaches to some kinds of public performances by women, and how much to the market value of sexual attraction.

\section{IV.-INTELLECTUAL WORK}

Here again we have few facts of economic significance. When a woman is exceptionally efficient, and does work of a kind usually performed by men, she seems to obtain her full ' Rent of Ability' without deduction on account of sex. The lady who acts as the Paris correspondent of the Daily Nezes, and she who governs the important Post Office at Gibraltar, ${ }^{1}$ both receive emoluments on at least a masculine scale.

Ten thousand pounds was paid to George Eliot for Romola, and a similar price is said to have been refused by a living lady novelist.

In other occupations the exceptional character of feminine training and ability gives women still something of 'monopoly value.' The earnings of the first womendoctors probably included some of this element. The editors of the leading Reviews seem inclined to give their few women contributors a higher rate of pay than is awarded for articles by men.

\section{CONCLUSION}

It is difficult to extract any general conclusion from the foregoing facts. Women workers appear almost invariably

1 See Colonial Office List for 1898 (Harrison and Sons). Both these ladies remain in the responsible positions which they held in 1891 . 
to earn less than men except in a few instances of exceptional ability, and in a few occupations where sexual attraction enters in. Where the inferiority of earnings exists, it is almost always coexistent with an inferiority of work. And the general inferiority of women's work seems to influence their wages in industries in which no such inferiority exists. In the 'genteel' vocations women habitually receive less than men; and in the case of clerks and teachers for work of quality and quantity often equal to the men's.

In very few cases is there such a uniformity of condition between men and women workers as to permit of conclusive comparison of their wages for equal work, and in a majority of these, equal wages are given.

Usually, however, the women perform some branch of work which is wholly abandoned to them by the men; and they refrain, whether willingly or not, from engaging in the branches monopolised by their male rivals. The line between the two classes of work is often subtle enough, and it varies from place to place. Moreover, wherever the dividing line may be in any particular locality at any given time, it shifts with almost every change in the industrial process ; moving, too, nearly always in the direction of leaving the women in possession of an ever larger industrial field. The economic boundary between men and women is constantly retreating on the men's side.

It would, however, be a mistake to conclude without further examination that this silent rectification of frontier necessarily implies an economic degradation of the male operatives. The field of employment for women may widen without really narrowing that for men. Economic history contains innumerable instances of the direct supersession of men by women, but men have certainly not fewer branches of employment open to them than their forefathers had.

For every piece of work abandoned to women several entirely new branches have sprung into existence for men, 
until the simple savage choice between hunting and fishing is now represented by the tens of thousands of separate occupations enumerated by the Registrar-General. When, in the New England cotton mills, successive waves of foreign immigration replaced the native Americans by English, and the English by French-Canadians, the highergrade labour was, in each case, not so much squeezed out by the lower as attracted out by the endless openings offered by the nation's rapid growth. It is equally difficult to resist, as regards our own country, the fact brought out by Sir Robert Giffen, that a much larger proportion of our greatly increased number of male operatives is now engaged in skilled handicrafts at good wages than was formerly the case. The ultimate effect of machinery, with the increased complexity of life which it occasions, is enormously to increase the number of skilled workers required. The field for men's employment, although constantly being curtailed on one side, is always widening out on the other.

The competition between men and women in industry, is, indeed, not so much a direct underselling in wages as a struggle to secure the better-paid kinds of work. Where women are, by exception, as efficient as the men workers, the usual low standard of women's wages (set, largely, by their general inefficiency) often enables them entirely to supersede the men, just as Chinese men have superseded American women in laundry work. Where, from one cause or another, men and women remain employed in exactly similar work, it is possible that the men expiate their lack of mobility by having their wages kept down to the level of the women's, a level set less by their efficiency in that particular industry than by comparison of what women earn elsewhere. These cases are, however, rare, because there is a constant tendency for the men to leave any such industry.

The advantages which secure to men nearly all the well-paid branches of manual labour are numerous. Even if the occupation is one in which physical strength is 
nominally not required, as in the case with compositors, it is nevertheless useful to be strong, either to lift the 'formes,' or to work long hours. Even where the women workers have thoroughly learnt their trade-an advantage seldom permitted to them-their lack of industrial experience makes them of less use than men in an emergency: less resourceful, for instance, on a breakdown. Often, indeed, women who are capable of doing nearly the whole of some industrial process, fail to master some incidental small part of it. Women weavers can seldom 'tune' or set their own looms. Women heraldic engravers have, curiously enough, never been able to point their own gravers, and have, in consequence, wholly abandoned that occupation. More commonly women workers are untrained, or only partially trained, for their work, and even if they learn to perform the lower branches of it well enough, they lack the masterly grasp which is required in the higher ranks of the industrial army.

It is upon advantages of this kind that rest both the popular view of the superiority of men over women workers, and the accepted custom in the division of employments. Where that custom is departed from, and women are successfully introduced into a new branch of industry, it is generally on the occasion of some change in the process whereby the work has been brought within the capacity of the woman worker. In such a case wages not unnaturally tend to fall, just as those of the 'Amalgamated' Engineer would fall if a new machine suddenly enabled his work to be done by a tramway conductor. It is not so much a supersession of men by women as of skilled workers by those less skilled.

Indeed, if we considered only cases of this class, there would be much to be said for the view that the inequality existing in remuneration between those occupations monopolised by men, and those to which women are relegated, might have no relation to sexual cleavage, but be merely a case of 'non-competing groups' of skilled and unskilled 
labour. If women workers in women's trades earn less than men in trades which are still exclusively men's, so do dockers earn less than carpenters, and even farm-labourers in Dorsetshire less than farm-labourers in Durham. The problem of the inequality of wages is one of great plurality of causes and intermixture of effects, and we might not improbably find that, as is often the case, there is no special 'women's question' in the matter.

The inferiority of women's wages is, however, to be gathered not so much from a comparison of the rates for identical work, for few such cases exișt, but rather from a comparison of the standards of remuneration in men's and women's occupations respectively. Looked at in this light it seems probable that women's work is usually less highly paid than work of equivalent difficulty and productivity done by men. The women earn less than men not only because they produce less, but also because what they produce is usually valued in the market at a lower rate.

The facts as yet ascertained hardly warrant any definite conclusions as to the causes of this difference. It exists both where the women are subject to exceptional legislative restrictions, and where these do not prevail; it exists in the United States, the Colonies and France, as well as in this country; it exists in clerical and educational as well as in manufacturing work; in mental as well as manual labour; where payment is made by the piece and where it is made by time; where custom rules and where competition. The problem is apparently one of great complexity, and no simple or universal solution of it can be offered.

I have sometimes been disposed to think that the question was mainly one of a 'non-competing' set of groups of relatively redundant and inefficient labourers, but little protected by combination. The case of the woman worker would, on this supposition, be economically analogous to that of the male unskilled labourer.

But it is impossible to overlook the effect of the fact that the woman has something else to sell besides her 
labour; and that many women are partially maintained out of other incomes than their own. I have been unable to satisfy myself to what extent these factors affect the standard wage of female manual workers. ${ }^{1}$ In so far as they do, the case becomes economically analogous to that of the unskilled labourer receiving a rate in aid of wages. Under the old poor law the labourer who, by exception, did not receive outdoor relief, found his wages reduced by the prevalence of the practice among his competitors.

The following suggestions as to causes are accordingly only put forward tentatively, as affording some indication of the directions in which further study of the question is needed :

A. Custom and public opinion: founded on the other causes, but more potent than them all, and prevailing in cases which they do not affect. Can be altered by (a) education of the public, especially as regards salaries paid by public bodies $;^{2}(b)$ greater public influence of women; (c) removal of the other causes of inferiority of wage.

B. Lower standard, caused partly by a lower standard of life both in physical needs and in mental demands; and partly by the presence of 'make-weights,' in the shape of assistance from family or husband. To be remedied by (a) teaching women to insist on a higher standard both of

1 Three cases must be distinguished, viz. : $(a)$ occasional prostitution, $(b)$ the possession of small means, and $(c)$ the employment of married women. On the latter point the chapter by Miss Clara Collet, in Mr. Charles Booth's Life and Labour of the People (now in vol. iv. of revised edition) should be consulted.

2 The influence of a lady on the Edinburgh School Board, and that of the Socialist members of the Newcastle School Board, has raised the salaries of the women teachers. Mr. Fawcett, when Postmaster-General, induced the Treasury to raise the initial salary for female clerks from $£ 45$ to $£ 65$ irrespective of market rates. On the other hand a glaring case of the contrary view took place in connection with the Royal Commission on Labour. The usual pay for clerks to temporary commissions is $42 \mathrm{~s}$. per week, and it was agreed by the Treasury that one might be obtained for the Labour Commission. The Commissioners chose to appoint a woman, who does the work to their entire satisfaction and as well, they think, as a man. But the Treasury, on learning that a woman had been appointed, cut down the pay to $35 \mathrm{~s}$. a week, on the ground that this was enough for a woman! 
physical needs and mental demands $;^{1}$ (b) greater independence of women; $(c)$ change in public opinion.

C. Lower productivity either in quantity or quality, caused by insufficient training or deficient strength; aided by irregularity of work through sickness, and lack of permanence through diversion by matrimony; and sometimes by greater incidental expenses of production through legal or social requirements, the difficulty of promoting women to the higher grades of work, or otherwise, the result of inferiority of work. ${ }^{2}$ To be remedied by (a) technical training for women; (b) greater independence among women; $(c)$ equal treatment by law.

D. Lack of protective power, through failure to combine, want of adaptability, limited number of alternatives, and greater immobility. ${ }^{3}$ To be remedied by (a) better education of women; (b) Greater freedom and independence; and $(c)$ change in public opinion removing feminine disabilities.

Summarising roughly these suggestions, it may be said that women's inferiority of remuneration for equivalent work is, where it exists, the direct or indirect result, to a very large extent, of their past subjection; and that, dependent as it now mainly is upon the influence of custom and public opinion, it might be largely removed by education and combination among women themselves. ${ }^{4}$

1 Might not women do more work, and better, if they learnt to eat more?

$2 \mathrm{Mr}$. David Schloss reminds me that an employer replacing 200 men by 300 women could not, without increasing expenses of production, pay the women the same piece-work rates as the men enjoyed : he would need more factory space, increased supervision, etc.

3 The improvement in cheap means of urban transit open to women (tramways, the tops of omnibuses, etc.) must have greatly increased their economic mobility in London, and hence their independence.

4 The following recent comparison between the women workers in Lancashire, where they have long been well organised, in alliance with their male colleagues, and those in Glasgow, whose organisation is very defective, is suggestive :-

'The contrast between a Scotch and a Lancashire weaving factory . . . is very remarkable. The Lancashire operative works with a will, she earns a high wage (on an average double that of her Scotch sister on the same class of work), and is anxious to maintain it. She will take charge of four power looms without hesitation. . . In Scotland, on the other hand, it is common to find weavers 
But further study has convinced me that much more than this is needed. The employment of women at insufficient wages is only a part of the general problem of what may be called 'parasitic labour,' which will, I am convinced, have to be dealt with, as a whole, in a more drastic way than I contemplated when I wrote the foregoing paper. This is the 'Policy of a National Minimum,' described in Industrial Democracy, to which the reader must be referred. ${ }^{1}$

with experience with only two power-looms, and it is with difficulty that they can be persuaded to take a third. . . . Practically there are almost no men employed in the cotton manufacture in Scotland, all the spinning and the weaving is done by women and young girls. The wages earned are low, and the best class of female operatives will not readily enter a factory.'-(Report of Chief Inspector of Factories, I890, p. 7, C. -6330.) For an explanation of the reason why the Scottish woman weaver refuses to take charge of more looms, see Industrial Democracy, vol. i. chap. viii. p. 428 .

1 With regard to the general question of women's wages, little has been written, from an economic standpoint, since the date of this contribution. The chapter in Professor Smart's Studies in Economics (London, 1895) remains practically the only serious treatment of the problem. Additional statistics with regard to women's earnings will be found in the Board of Trade Report on the Wages of the Manual Labour Classes in the United Kingdom (C. -6889 of 1893), which gives the wages of dressmakers, tailoresses, nurses, stewardesses, and servants in large households and in hospitals and infirmaries. Among American statistics the most important are the Eleventh Annual Report of the Federal Bureau of Statistics of Labour on ' work and wages of men, women, and children'; the Seventh Biennial Report of the Bureau of Labour Statistics of Illinois (I 895), with regard to Chicago; and the chapters in the Labour Bureau reports of other states. Useful statistics of relative men's and women's wages in France are given in the report of the French 'Office du Travail,' entitled Salaires et Durke du Travail dans IIndustrie Francaise (4 vols. 1896-8); and with regard to those of waitresses and shop assistants in Germany, in the special reports of the German Imperial Statistical Office. The student should also consult the reports on Home Work published with regard to London, Glasgow, Manchester, Vienna, and Berlin. On the general statistics of women's employment in the United Kingdom, Miss Collet's paper, read before the Statistical Society in March 1898, should be studied. 


\section{CHAPTER IV}

\section{WOMEN AND THE FACTORY ACTS ${ }^{1}$}

THE discussions on the Factory Act of $1895^{2}$ raised once more all the old arguments about Factory legislation, but with a significant new cleavage. This time legal regulation was demanded, not only by all the organisations of working women whose labour was affected, ${ }^{3}$ but also by, practically, all those actively engaged in Factory Act administration. The four women Factory Inspectors unanimously confirmed the opinion of their male colleagues. Of all the classes 4 having any practical experience of Factory legislation, only one-that of the employers-was ranged against the Bill, and that not unanimously. But the employers had the powerful aid of most of the able and devoted ladies who have usually led the cause of women's enfranchisement, and whose strong theoretic objection to Factory legislation caused many of the most important clauses in the Bill to be rejected.

1 Reproduced with some additions, from papers read at the Nottingham Conference of the National Union of Women Workers (October I895), and the Fabian Society (January 1896).

2 Factory and Workshop Act 1895 (58 \& 59 Vict. ch. 37).

3 Petitions were sent in, and meetings held in support of the Bill by, I believe, all the Trade Unions of Women, as well as by the Women's Co-operative Guild, which is mainly composed of women textile workers, whose hours of labour have, for half a century, been rigidly fixed by law.

4 See the Report of the Chief Inspector of Factories for 1894, C. 7745; also the Opinions on Overtime, published by the Women's Trade Union League (Club Union Buildings, Clerkenwell Road, London). The evidence before the Royal Commission on Labour was decidedly in favour of an extension of, and the more rigid enforcement of Factory legislation : see, in particular, the Minority Report (published separately by the Manchester Labour Press, Tib Street, Manchester). 
The ladies who resist further legal regulation of women's labour usually declare that their objection is to special legislation applying only to women. They regard it as unfair, they say, that women's power to compete in the labour market should be 'hampered' by any regulation from which men are free. Any such restriction, they assert, results in the lowering of women's wages, and in diminishing the aggregate demand for women's work. I shall, later on, have something to say about this assumed competition between men and women. But it is curious that we seldom find these objectors to unequal laws coming forward to support even those regulations which apply equally to men and to women. Nearly all the clauses of the I 895 Bill, for instance, and nearly all the amendments proposed to it, applied to men and women alike. The sanitary provisions; the regulations about fire-escapes; the pre-eminently important clause making the giver-out of work responsible for the places where his work is done; the power to regulate unhealthy trades or processes: all these made no distinction between the sexes. Yet the ladies who declared that they objected only to inequality of legislation, gave no effective aid to the impartial sections of the Bill. If we believe that legal regulation of the hours and conditions of labour is found, in practice, to promote the economic independence and positively to add to the industrial efficiency of the workers concerned, why should we not help women workers in unregulated trades to gain this superior economic position, even if Parliament persists in denying it to the men? It is clear that there lurks behind the objection of inequality an inveterate scepticism as to the positive advantages of Factory legislation. Indeed, the most energetic and prominent opponents of women's Factory Acts openly avow as much. Mrs. Henry Fawcett and Miss Ada Heather-Bigg, for instance, usually speak of legal regulation as something which, whether for men or for women, decreases personal freedom, diminishes productive capacity, and handicaps the worker in the struggle for existence. I need not recall how firmly and conscientiously 
this view was held by men like Nassau Senior and John Bright in the generation gone by. To-day there are evidently many ladies of education and position superstitiously clinging to the same belief. Therefore before discussing whether any particular Factory Act is good for women or not, we had better make up our minds on the general question. Does State regulation of the hours and conditions of labour increase or decrease the economic independence and industrial efficiency of the workers concerned?

Now those who object to further Factory legislation are right in asserting that the issue cannot be decided by harrowing accounts of factory tyranny, or particular cases of cruelty or hardship. I shall not trouble you with the long list of calamities in the unregulated trades, on which the official report of the Chief Inspector of Factories lays so much stress - the constitutions ruined by long hours in dressmakers' workrooms or insanitary laundries, the undermining of family life by the degradation of the home into a workshop, the diseases and deaths caused by white lead and lucifer matches. And, I hope, no one in the discussion will think it any argument against Factory Acts that some poor widow might find it more difficult to get bread for her starving children if she were forbidden to work at the white lead factory; that some sick man's daughter would not be allowed to earn the doctor's fee by taking extra work home after her factory day; or that some struggling laundress might find it impossible to make a living if she could not employ her girls for unlimited hours. Either way there must be hard cases, and individual grievances. The question is whether, taking the whole population and all considerations into account, the evils will be greater under regulation or under free competition.

Let us concede to the opponents of Factory legislation that we must do nothing to impair or limit the growing sense of personal responsibility in women; that we must seek, in every way, to increase their economic independence, and their efficiency as workers and citizens, not less than as 
wives and mothers; and that the best and only real means of attaining these ends is the safeguarding and promoting of women's freedom. The only question at issue is how best to obtain this freedom. When we are concerned with the propertied classes-when, for instance, it is sought to open up to women higher education or the learned professionsit is easy to see that freedom is secured by abolishing restrictions. But when we come to the relations between capital and labour an entirely new set of considerations come into play. In the life of the wage-earning class, absence of regulation does not mean personal freedom. Fifty years' experience shows that Factory legislation, far from diminishing individual liberty, greatly increases the personal freedom of the workers who are subject to it. Every one knows that the Lancashire woman weaver, whose hours of labour and conditions of work are rigidly fixed by law, enjoys, for this very reason, more personal liberty than the unregulated laundrywoman in Notting Hill. She is not only a more efficient producer, and more capable of associating with her fellows in Trade Unions, Friendly Societies, and Co-operative Stores, but an enormously more independent and self-reliant citizen. It is the law, in fact, which is the mother of freedom. ${ }^{1}$

To understand the position fully we must realise how our long series of Factory Acts, Truck Acts, Mines Regulation Acts, and Shop Hours Acts, have come into existence. ${ }^{2}$ All these are based upon a fundamental economic fact which has slowly forced itself into the minds of economists and social reformers-the essential and permanent inequality between the individual wage-earner and the capitalist employer. When the conditions of the workman's life are settled, without any collective regulation, by absolutely free contract between man and man, the workman's freedom is entirely delusive. Where he bargains, he bargains at a hopeless disadvantage; and on many of the points most

1 This was pointed out by the Duke of Argyll, in the final chapter of his Reign of Law, which deals with Factory legislation.

2 See W. C. Taylor, The Modern Factory System; Von Plener's English Factory Legislation; and Miss Victorine Jeans' Factory Act Legislation. 
vital to his health, efficiency, and personal comfort, he is unable to bargain at all.

Let us see how this comes about. I will not, to prove my point, take a time of bad trade, when five workmen are competing for one situation: I will assume that the whole labour market is in a state of perfect equilibrium; that there is only one workman wanting work, and only one situation vacant. Now, watch the process of bargaining between the employer and the workman. If the capitalist refuses to accept the workman's terms, he will, no doubt, suffer some inconvenience as an employer.' To fulfil his orders he will have to 'speed up' some of his machinery, or insist on his workpeople working longer hours. Failing these expedients he may have to delay the delivery of his goods, and may even find his profits, at the end of the year, fractionally less than before. But, meanwhile, he goes on eating and drinking, his wife and family go on living, just as before. His physical comfort is not affected : he can afford to wait until the labourer comes back in a humbler frame of mind. And that is just what the labourer must presently do. For he, meanwhile, has lost his day. His very subsistence depends on his promptly coming to an agreement. If he stands out, he has no money to meet his weekly rent, or to buy food for his family. If he is obstinate, consumption of his little hoard, or the pawning of his furniture, may put off the catastrophe; but sooner or later slow starvation forces him to come to terms. This is no real freedom of contract. The alternative on one side is inconvenience; on the other it is starvation. I need not remind you that the fallacy of free and equal contract between capital and labour has been long since given up by the economists. If you read, for instance, our foremost economist, Professor Marshall, he will tell you that the employer is a combination in himself, with whom the individual wage-earner is seriously at a disadvantage. ${ }^{1}$

1 See, for instance, the Elements of the Economics of Industry (1892), p. 382. This whole argument is further developed, and the inequality shown to be an all-pervading characteristic of the modern business organisation, in Industrial Democracy, vol. ii. 'The Higgling of the Market.' 
No competent authority would now deny that unfettered individual bargaining between capitalist and workman inevitably tends to result, not in the highest wage that the industry can afford, but in the lowest on which the workman and his family can subsist.

Here, then, we have the first justification for something more than unfettered bargaining between man and man. But this is not all. We often forget that the contract between employer and workman is to the employer simply a question of the number of shillings to be paid at the end of the week. To the workman it is much more than that. The wage-earner does not, like the shopkeeper, merely sell a piece of goods which is carried away. It is his whole life which, for the stated term, he places at the disposal of his employer. What hours he shall work, when and where he shall get his meals, the sanitary conditions of his employment, the safety of the machinery, the atmosphere and temperature to which he is subjected, the fatigue or strains which he endures, the risks of accident or disease which he has to incur: all these are involved in the workman's contract and not in his employer's. Yet about the majority of these vital conditions he cannot bargain at all. Imagine a weaver, before accepting employment in a Lancashire cotton-mill, examining the quantity of steam in the shed, the strength of the shuttle-guards, and the soundness of the belts of the shafting; an engineer prying into the security of the hoists and cranes, or the safety of the lathes and steam-hammers among which he must move; a dressmaker's assistant computing the cubic space which will be her share of the workroom, criticising the ventilation, warmth and lighting, or examining the decency of the sanitary accommodation; think of the woman who wants a job at the whitelead works, testing the poisonous influence in the particular process employed, and reckoning, in terms of shillings and pence, the exact degree of injury to her health which she is consenting to incur. No sensible person can really assert that the individual operative seeking a job has either the 
knowledge or the opportunity to ascertain what the conditions are, or to determine what they should be, even if he could bargain about them at all. On these matters, at any rate, there can be no question of free contract. We may, indeed, leave them to be determined by the employer himself: that is to say, by the competition between employers as to who can most reduce the expenses of production. What this means, we know from the ghastly experience of the early factory system; when whole generations of our factory hands were stunned and maimed, diseased and demoralised, hurried into early graves by the progressive degeneration of conditions imposed on even the best employers by the reckless competition of the worst. ${ }^{1}$ The only alternative to this disastrous reliance on a delusive freedom is the settlement, by expert advice, of standard conditions of health, safety, and convenience, to which all employers, good and bad alike, are compelled by law to conform.

We see, therefore, that many of the most vital conditions of employment cannot be made subjects of bargain at all, whilst, even about wages, unfettered freedom of individual bargaining places the operative at a serious disadvantage. But there is one important matter which stands midway between the two. In manual work it is seldom that an individual can bargain as to when he shall begin or leave off work. In the most typical processes of modern industry, individual choice as to the length of the working day is absolutely impossible. The most philanthropic or easy-going builder or manufacturer could not possibly make separate arrangements with each of his workpeople as to the times at which they should come and go, the particular intervals for meals, or what days they should take as holidays. Directly we get machinery and division of labour-directly we have more than one person working at the production of an article, all the persons concerned are compelled, by the very nature

1 Some account of this development is given in the first chapter of my Co. operative Movement in Great Britain. See also Engels' Condition of the English Working Classes in 1844, or Arnold Toynbee's The Industrial Revolution. 
of their occupation, to work in concert. This means that there must be one uniform rule for the whole establishment. Every workman must come when the bell rings, and stay as long as the works are open; individual choice there can be none. The hours at which the bell shall ring must either be left to the autocratic decision of the employer, or else settled by collective regulation to which every workman is compelled to conform.

We can now understand why it is that the representative wage-earner declares, to the astonishment of the professional man or the journalist, that a rule fixing his hours of labour, or defining conditions of sanitation or safety, is not a restriction on his personal liberty. The workman knows by experience that there is no question of his ever settling these matters for himself. There are only two alternatives to their decision by the employer. One is their settlement by a conference between the representatives of the employers and the representatives of the organised workmen; both sides, of course, acting through their expert salaried officials. This is the method of collective bargaining - in short, Trade Unionism. The other method is the settlement by the whole community of questions which affect the health and industrial efficiency of the race. Then we get expert investigation as to the proper conditions, which are enforced by laws binding on all. This is the method of Factory legislation.

No greater mistake can be made in comparing these two methods than to assume that Trade Unionism sacrifices the imaginary personal liberty of the individual workman to make his own bargain any less than Factory legislation. Take, for instance, the Oldham weaver. Here we see both methods at work. The rate of wages is determined entirely by Trade Unionism; the hours of labour and sanitary conditions are fixed by law. But there is no more individual choice in the one than in the other. I do not hesitate to say, indeed, that an employer or a weaver would find it easier and less costly to defy the Factory Inspector and 
work overtime, than to defy the Trade Union official and evade the Piecework List of Prices. Or, take the Northumberland coal-miner. He, for particular reasons, objects to have his hours fixed by law. But we need be under no delusion as to his views on 'personal liberty.' If any inhabitant of a Northumberland village offered to hew coal below the rate fixed by the Trade Union for the whole county, or if he proposed to work two shifts instead of one, the whole village would rise against him, and he would find it absolutely impossible to descend the mine, or to get work anywhere in the county. It is not my business to-day either to defend or to criticise Trade Union action. But we cannot understand this question without fully realising that Trade Unionism, in substituting for the despotism of the employer or the individual choice of the workman a general rule binding on all concerned, is just as much founded on the subordination of the individual whim to the deliberate decision of the majority as any law can be. If I had the time I could show you, by elaborate technical arguments, how the one method of over-riding the individual will is best for certain matters, and the other method more expedient in regard to other matters. (Rates of wages, for instance, are best settled by collective bargaining; and sanitation, safety, and the prevention of overwork by fixed hours of labour are best secured by legal enactment. ?

But this question of the relative advantages of legislative regulation and Trade Unionism has unhappily no bearing on the women employed in the sweated industries. Before we can have Trade Union regulation we must build up strong Trade Unions; and the unfortunate women workers whose overtime it was proposed to curtail, and whose health and vigour it was proposed to improve, by Mr. Asquith's Bill of I 895, are without any effective organisation. The Lancashire women weavers and card-room hands were in the same predicament before the Factory Acts. It was only when they were saved from the unhealthy conditions and excessive hours of the cotton-mills of that time that they began to 
combine in Trade Unions, to join Friendly Societies, and to form Co-operative Stores. This, too, is the constant experience of the men's trades. Where effective Trade Unions have grown up, legal protection of one kind or another has led the way. ${ }^{1} \quad$ And it is easy to see why this is so. Before wage-earners can exercise the intelligence, the deliberation, and the self-denial that are necessary for Trade Unionism, they must enjoy a certain standard of physical health, a certain surplus of energy, and a reasonable amount of leisure. It is cruel mockery to preach Trade Unionism, and Trade Unionism alone, to the sempstress sewing day and night in her garret for a bare subsistence; to the laundrywoman standing at the tub eighteen hours at a stretch; or to the woman whose health is undermined with 'Wrist-drop,' 'Potter's-rot,' or 'Phossy-jaw.' If we are really in earnest in wanting Trade Unions for women, the way is unmistakable. If we wish to see the capacity for organisation, the selfreliance, and the personal independence of the Lancashire cotton weaver spread to other trades, we must give the women workers in these trades the same legal fixing of hours, the same effective prohibition of overtime, the same legal security against accident and disease, the same legal standard of sanitation and health as is now enjoyed by the women in the Lancashire cotton-mills.

Sc much for the general theory of Factory legislation. We have still to deal with the special arguments directed against those clauses of the I 895 Bill which sought to restrict the overtime worked by women in the sweated trades. If, however, we have fully realised the advantages, both direct and indirect, which the workers obtain from the legal regulation of their labour, we shall regard with a good deal of suspicion any special arguments alleged in opposition to any particular Factory Acts. The student of past factory agitations sees the same old bogeys come up again

1 For proof of this see The History of Trade Unionism, by Sidney and Beatrice Webb, particularly the first chapter; and on the whole subject, see the elaborate analysis in Industrial Democracy. 
and again. Among these bogeys the commonest and most obstructive has always been that of foreign competition, that is to say, the risk that the regulated workers will be supplanted by 'free labour' - whether of other countries or of other classes at home. At every step forward in legal regulation the miner and the textile worker have been solemnly warned that the result of any raising of their standard of sanitation, safety, education or leisure would be the transference of British capital to China or Peru. And to my mind it is only another form of the same fallacy when capitalists' wives and daughters seek to alarm working women by prophesying, as the result of further factory legislation, the dismissal of women and girls from employment and their replacement by men. The opposition to factory legislation never comes from workers who have any practical experience of it. Every existing organisation of working women in the kingdom has declared itself in favour of factory legislation. Unfortunately, working women have less power to obtain legislation than middle-class women have to obstruct it. Unfortunately, too, not a few middleclass women have allowed their democratic sympathies and collectivist principles to be overborne by this fear of handicapping women in their struggle for employment. Let us, therefore, consider, as seriously as we can, this terror lest the capitalist employing women and girls at from five to twelve shillings a week, should, on the passage of a new Factory Act, replace them by men at twenty or thirty shillings.

First let us realise the exact amount of the inequality between the sexes in our Factory Acts. All the regulations with respect to safety, sanitation, employers' liability, and age, apply to men and women alike. The only restriction of any importance in our Labour Code which bears unequally on men and women is that relating to the hours of labour. ${ }^{1} \quad U_{p}$ to now there has been sufficient influence

1 The Lawe relating to Factories and Workshops, by May Abraham and A. Llewellyn Davies (Eyre and Spottiswoode, 1896), contains a convenient summary of all the Acts. With regard to hours, the main provisions are as 
among the employers, and sufficient prejudice and misunderstanding among legislators, to prevent them expressly legislating, in so many words, about the hours of labour of adult men. That better counsels are now prevailing is shown by the fact that Parliament in 1892 gave power to the Board of Trade to prevent excessive hours of work among railway servants, and that the Home Secretary has now a similar power in respect of any kind of manual labour which is injurious to health or dangerous to life and limb. I need hardly say that I am heartily in favour of regulating, by law, the hours of adult men, wherever and whenever possible. ${ }^{1} \quad$ But although the prejudice is breaking down, it is not likely that the men in the great staple industries will be able to secure for themselves the same legal limitation of hours and prohibition of overtime that the women in the textile manufactures have enjoyed for nearly forty years. And thus it comes about that some of the most practical proposals for raising the condition of the women in the sweated trades must take the form of regulations applying to women only.

It is frequently asserted as self-evident that any special limitation of women's labour must militate against their employment. If employers are not allowed to make their women work overtime, or during the night, they will, it is said, inevitably prefer to have men. Thus, it is urged, any extension of factory legislation to trades at present un-

follows : Textile factories employing women or children, may work only between 6 A.M. and 6 P.M. (or 7 A.M. and 7 P.M.), only $56 \frac{1}{2}$ hours net per week, and overtime is absolutely prohibited. In non-textile factories and in ordinary workshops, women may be worked 60 hours per week, overtime is (usually) permitted under certain conditions, and the day's work may (except on Saturdays) range over a period from 6 A.M. to 8 P.M., or, if no children or young persons are employed, even from 6 A.M. to Io P.M. This absence of a precisely determined legal working-day makes it practically impossible to enforce the law. In 'domestic workshops' there is no restriction on women's hours, and in laundries the only limit is a general one of sixty hours per week (or fourteen in any one day), without regulation of the hours of beginning or ending, or of mealtimes. This is quite illusory.

1 See the subsequent chapter on The Regulation of the Hours of Labour, and Fabian Tract, No. 48, Eight Hours by Law: a Practicable Solution. 
regulated must diminish the demand for women's labour. But this conclusion, which seems so obvious, really rests on a series of assumptions which are not borne out by facts.

The first assumption is, that in British industry to-day, men and women are actively competing for the same employment. I doubt whether any one here has any conception of the infinitesimal extent to which this is true. We are so accustomed, in the middle-class, to see men and women engaged in identical work, as teachers, journalists, authors, painters, sculptors, comedians, singers, musicians, medical practitioners, clerks, or what not, that we almost inevitably assume the same state of things to exist in manual labour and manufacturing industry. But this is very far from being the case. To begin with, in over ninetenths of the industrial field there is no such thing as competition between men and women: the men do one thing, and the women do another. There is no more chance of our having our houses built by women than of our getting our floors scrubbed by men. And even in those industries which employ both men and women, we find them sharply divided in different departments, working at different processes, and performing different operations. In the tailoring trade, for instance, it is often assumed that men and women are competitors. But in a detailed investigation of that trade I discovered that men were working at entirely separate branches to those pursued by the women. And when my husband, as an economist, tried to demonstrate the oft-repeated statement that women are paid at a lower rate than men, he found it very difficult to discover any trade whatever in which men and women did the same work. ${ }^{1}$ As a matter of fact, the employment of men or women in any particular industry is almost always determined by the character of the process. In many cases the physical strength or endurance required, or the exposure

1 See chap. iii. 'Women's Wages'; and on the general question, Studies in Economics, by Professor W. Smart (London, 1895), and the valuable report by Miss Clara Collet, on the Statistics of Employment of Women and Girls, published by the Labour Department of the Board of Trade (C.-7564), I 894. 
involved, puts the work absolutely out of the power of the average woman. No law has hindered employers from engaging women as blacksmiths, steel-smelters, masons, or omnibus-drivers. The great mass of extractive, constructive, and transport industries must always fall to men. On the other hand, the women of the wage-earning class have hitherto been distinguished by certain qualities not possessed by the average working-man. For good or for evil they eat little, despise tobacco, and seldom get drunk; they rarely strike or disobey orders ; and they are in many other ways easier for an employer to deal with. Hence, where women can really perform a given task with anything like the efficiency of a man, they have, owing to their lower standard of expenditure, a far better chance than the man of getting work. The men, in short, enjoy what may be called a 'rent' of superior strength and endurance; the women, on their side, in this preference for certain employments, what may be called a 'rent' of abstemiousness.

I do not wish to imply that there are absolutely no cases in British industry in which men and women are really competing with each other. It is, I believe, easy to pick out an instance here and there in which it might be prophesied that the removal of an existing legal restriction might, in the first instance, lead to some women being taken on in place of men. In the book and printing trade of London, for instance, it has been said that if women were allowed by law to work all through the night, a certain number of exceptionally strong women might oust some men in book-folding and even in compositors' work. ${ }^{1}$ We must not overlook these cases; but we must learn to view them in their proper proportion to the whole field of industry. It would clearly be a calamity to the cause of women's advancement if we were to sacrifice the personal liberty and economic independence of three or four millions of

1 With regard to the employment of women as compositors, chap. iii. 'Women's Wages,' and the article by Amy Linnett, in the Economic Review for January 1892 , should be referred to. 
wage-earning women in order to enable a few hundreds or a few thousands to supplant men in certain minor spheres of industry. ${ }^{1}$

The second assumption is, that in the few cases in which men and women may be supposed really to compete with each other for employment, the effect of any regulation of women's hours is pure loss to them, and wholly in favour of their assumed competitors who are unrestricted. This, I believe, is simply a delusion. Any investigator of women's work knows full well that what most handicaps women is their general deficiency in industrial capacity and technical skill. Where the average woman fails is in being too much of an amateur at her work, and too little of a professional. Doubtless it may be said that the men are to blame here: it is they who induce women to marry, and thus divert their attention from professional life. But though we cannot cut at the root of this, by insisting, as I once heard it gravely suggested, on 'three generations of unmarried women,' we can do a great deal to encourage the growth of professional spirit and professional capacity among women workers, if we take care to develop our industrial organisation along the proper lines. The first necessity is the exclusion of illegitimate competitors. The real enemies of the working woman are not the men, who always insist on higher wages, but the 'amateurs' of her own sex. So long as there are women, married or unmarried, eager and able to take work home, and do it in the intervals of another profession, domestic service, we shall never disentangle ourselves from that vicious circle in which low wages lead to bad work, and bad work compels low wages. The one practical remedy for this disastrous competition is the extension of Factory legislation, with its strict limitation of women's hours, to all

1 Looked at from the point of view of the whole community, and not merely from that of one sex, it would, of course, be a matter for further consideration whether, and in what directions, it is socially desirable that men should be replaced by women as industrial operatives. Throughout the chapter I have abstained from discussing this consideration. 
manufacturing work wherever carried on. ${ }^{1}$ It is no mere coincidence that the only great industry in which women get the same wages as men-Lancashire cotton weavingis the one in which precise legal regulation of women's hours has involved the absolute exclusion of the casual amateur. No woman will be taken on at a cotton mill unless she is prepared to work the full factory hours, to come regularly every day, and put her whole energy into her task. In a Lancashire village a woman must decide whether she will earn her maintenance by working in the mill or by tending the home : there is no 'betwixt and between.' The result is a class of women wage-earners who are capable of working side by side with men at identical tasks; who can earn as high wages as their male competitors; who display the same economic independence and professional spirit as the men; and who are, in fact, in technical skill and industrial capacity, far in advance of any other class of women workers in the kingdom. ${ }^{2}$ If we want to bring the women wage-earners all over England up to the level of the Lancashire cotton weavers, we must subject them to the same conditions of exclusively professional work.

There is another way in which the extension of the Factory Acts to the unregulated trades is certain to advance women's industrial position. We have said that the choice of men or women as workers is really determined by the nature of the industrial process. Now these processes are constantly changing; new inventions bring in new methods of work, and often new kinds of machinery. This usually means an entire revolution in the character of the labour required. What to-day needs the physical strength or the life-long apprenticeship of the skilled handicraftsman may, to-morrow, by a new machine, or the use of motive power, be suddenly brought within the capacity of the nimble fingers of a girl from the Board School. It is in this sub-

1 See Fabian Tract, No. 50, Sweating: its Cause and Remedy.

2 See the introduction, by Mr. A. J. Mundella, to Von Plener's English Factory Legislation. 
stitution of one process for another that we discover the real competition between different classes or different sexes in industry. The tailoring trade, for instance, once carried on exclusively by skilled handicraftsmen, is now rapidly slipping out of their hands. But it is not the woman free to work all the night in her garret who is ousting the male operative. What is happening is that the individual tailor, man or woman, is being superseded by the great clothing factories established at Leeds, ${ }^{1}$ or elsewhere, where highly-paid skilled designers prepare work for the costly 'cutting-out' guillotines, and hundreds of women guide the pieces through self-acting sewing and button-holing machines, to be finally pressed by steam power into the 'smart new suit' of the City clerk.

Now this evolution of industry leads inevitably to an increased demand for women's labour. Immediately we substitute the factory, with its use of steam power, and production on a large scale, for the sweater's den or the domestic workshop, we get that division of labour and application of machinery which is directly favourable to the employment of women. It is to 'the factory system, and the consequent growth of the ready-made trade,' declares Miss Collet; that must 'be traced the great increase in the number of girls employed in the tailoring trade.' 2 The same change is going on in other occupations. Miss Collet notices that the employment of female labour has specially increased in the great industry of boot and shoe making. ${ }^{3}$ But, as in the analogous case of the tailoring trade, the increase has not been in the number of the unregulated women workers in the sweaters' dens. Formerly we had a man working in his own room, and employing his wife and daughter to help him at all hours. Some people might have argued that anything which struck at the root of this system would deprive women of employment. As a matter of fact, the result has been, by division of labour in the

1 See 'Women's Work in Leeds,' by Miss Clara Collet (Economic Journal, September I891, pp. 467-472).

2 Statistics of Employment of Women and Girls, C. -7564, p. I I.

s Ibill. p. 73. 
rapidly growing great boot factories, to substitute for these few hundreds of unpaid assistants, many thousands of independent and regularly employed women operatives. For we must remember that when these changes take place, they take place on a large scale. Whilst the Society for Promoting the Employment of Women is proud to secure new openings for a few scores or a few. hundreds, the industrial evolution which I have described has been silently absorbing, in one trade or another, hundreds of thousands of women of all classes. It is therefore infinitely more important for the friends of women's employment to inquire how an extension of the Factory Acts would influence our progress towards the factory system, than how it would affect, say, the few hundred women who might be engaged in night-work bookfolding.

If there is one result more clearly proved by experience than another, it is that the legal fixing of definite hours of labour, the requirement of a high standard of sanitation, and the prohibition of overtime, all favour production on a large scale. It has been the employers' constant complaint against the Factory Acts that they inevitably tend to squeeze out the 'little master.' The evidence taken by the House of Lords' Committee on Sweating conclusively proved that any effective application of factory regulations to the workplaces of East London and the Black Country would quickly lead to the substitution of large factories. Factory legislation is, therefore, strenuously resisted by the 'little masters,' who carry on their workshops in the back slums; by the Jewish and other subcontractors who make a living by organising helpless labour; and by all who cherish a sentimental yearning for domestic industries. But this sentiment must not blind us to the arithmetical fact that it is the factory system which provides the great market for women's labour. Those well-meaning ladies who, by resisting the extension of Factory legislation, are keeping alive the domestic workshop and the sweaters' den, are thus positively curtailing the sphere of women's employment. The 'freedom' of the poor 
widow to work, in her own bedroom, 'all the hours that God made'; and the wife's privilege to supplement a drunken husband's wages by doing work at her own fireside, are, in sober truth, being purchased at the price of the exclusion from regular factory employment of thousands of 'independent women.'

We can now sum up the whole argument. The case for Factory legislation does not rest on harrowing tales of exceptional tyranny, though plenty of these can be furnished in support of it. It is based on the broad facts of the capitalist system, and the inevitable results of the Industrial Revolution. A whole century of experience proves that where the conditions of the wage-earner's life are left to be settled by 'free competition' and individual bargaining between master and man, the worker's 'freedom' is delusive. Where he bargains, he bargains at a serious disadvantage, and on many of the points most vital to himself and to the community he cannot bargain at all. The common middleclass objection to Factory legislation-that it interferes with the individual liberty of the operative - springs from ignorance of the economic position of the wage-earner. Far from diminishing personal freedom, Factory legislation positively increases the individual liberty and economic independence of the workers subject to it. No one who knows what life is among the people in Lancashire textile villages on the one hand, and among the East End or Black Country unregulated trades on the other, can ever doubt this.

All these general considerations apply more forcibly to women wage-earners than to men. Women are far more helpless in the labour market, and much less able to enforce their own common rule by Trade Unionism. The only chance of getting Trade Unions among women workers lies through the Factory Acts. We have before us nearly fifty years' actual experience of the precise limitation of hours and the absolute prohibition of overtime for women workers in the cotton manufacture; and they teach us nothing that 
justifies us in refusing to extend the like protection to the women slaving for irregular and excessive hours in laundries, dressmakers' workrooms, and all the thousand and one trades in which women's hours of work are practically unlimited.

Finally, we have seen that the fear of women's exclusion from industrial employment is wholly unfounded. The uniform effect of Factory legislation in the past has been, by encouraging machinery, division of labour, and production on a large scale, to increase the employment of women, and largely to raise their status in the labour market. At this very moment the neglect to apply the Factory Acts effectively to the domestic workshop is positively restricting the demand for women workers in the clothing trades. And what is even more important, we see that it is only by strict regulation of the conditions of women's employment that we can hope for any general rise in the level of their industrial efficiency. The real enemy of the woman worker is not the skilled male operative, but the unskilled and half-hearted female 'amateur' who simultaneously blacklegs both the workshop and the home. The legal regulation of women's labour is required to protect the independent professional woman worker against these enemies of her own sex. Without this regulation it is futile to talk to her of the equality of men and women. With this regulation, experience teaches us that women can work their way in certain occupations to a man's skill, a man's wages, and a man's sense of personal dignity and independence. 


\section{CHAPTER V}

THE REGULATION OF THE HOURS OF LABOUR ${ }^{1}$

IN I $844 \mathrm{Mr}$. Greville wrote in his diary :-

I never remember so much excitement as has been caused by Ashley's Ten Hours Bill, nor a more curious political state of thingssuch intermingling of parties, such a confusion of opposition. . . . John Russell voting for 'ten hours,' against all he professed last year, has filled the world with amazement. . . . The Opposition were dividedPalmerston and Lord John one way, Baring and Labouchere the other. It has been a very queer affair. Some voted, not knowing how they ought to vote, and following those they are accustomed to follow ; many who voted against Government, afterwards said they believed they were wrong. Melbourne is all against Ashley; all the political economists, of course; Lord Spencer strong against him. Then Graham gave the greatest offence by taking up a word of the Examiner's last Sunday, and calling it a Jack Cade legislation; this stirring them to fury, and they flew upon him like tigers. . . . The whole thing is difficult and unpleasant. $^{2}$

Since that date about fifty Acts of the nature of Factory Acts have been passed, and the world is richer by half a century of experience of the result of such legislation. Nevertheless, when next year, or the year after, Lord Ashley's successor in 'Jack Cade legislation,' whoever he may be, introduces the 'Eight Hours Bill,' which the rising Democratic tide is now making inevitable; it can easily be foreseen that the House of Commons of to-day will be little better prepared for the proposal than was the House of

1 Contemporary Review, December 1889.

2 Journal of the Reign of Queen Victoria, vol. ii. p. 236 (March 31, 1844). 
1844. It may be safely predicted that the division will again be, to the unseen political Greville of the hour, 'a very queer affair.' 'The Opposition' will, perhaps, once more be divided; Radicals like Mr. Labouchere may not improbably follow in the cautious footsteps of his uncle, but the world will be surprised to find some very sturdy politicians voting in favour of the Bill, even 'against all they professed' some time ago. The Home Secretary will possibly not venture to repeat his predecessor's unhappy epithet, but some representative of the Liberty and Property Defence League will doubtless supply the omission, and it is quite certain that every political wire-puller will once again regard the whole thing as 'difficult and unpleasant.' And, to sum up, just as the Ten Hours Bill passed within three years of Mr. Greville's entry, so every politician knows in his heart of hearts that a reasonable Eight Hours Act will probably be one of the earliest fruits of the next general election. ${ }^{1}$

This incoherence of political opinion upon such an important social reform as an extension of the Factory Acts, is due rather to ignorance and misapprehension than to any class feeling or selfish interest. Burke's dictum, that the generality of people are fifty years behind in their politics, is as true to-day as it was a hundred years ago, and almost as applicable to the members of a popularly elected legislature as it was to the 'King's friends.' We are now rolling in the trough of the great wave of laisser faire, which set out from Rousseau and Adam Smith, and submerged all intellectual landmarks two generations ago. These have since recovered from the flood, but the main body of dim unconscious principle and tradition which

1 This deliberately sanguine prophecy came very near fulfilment. The coalminers' Eight Hours Bill passed its second reading in the House of Commons in 1893, but was abandoned after a rebuff in committee. In I895 the Railways Regulation Act became law, under which the Board of Trade is empowered, whenever it considers the hours of labour of any railway servants too long, to require the railway company to prepare a new schedule of hours, to the satisfaction of the Board, under heavy penalties for non-compliance. Under this Act the hours of many thousands of adult male workers have been compulsorily shortened. 
makes up the mind of the average Englishman is still waterlogged, and the shallow economic optimism of Bastiat has actually got into cheap editions. The ordinary member of Parliament prefers to ignore the Factory Acts, and continues to regard them as an exceptional and somewhat hazardous temporary expedient, just as he ignores the rapidly progressing municipalisation of industry, and the steadily increasing nationalisation, by taxation, of both rent and interest. His mind remains caught in the individualist thicket of the last century, and though the industrial revolution has compelled him from time to time widely to depart from his professed principles, he is still unconscious of the extent to which it has rendered his most cherished political beliefs a mere exploded superstition. As regards actual legislation and practical collectivist administration he has empirically led the world; in economic theory and political principle he, like the Bourbons, has usually learnt nothing and forgotten nothing.

The scientific verdict on the results of Factory legislation is, however, clear enough. In I $844 \mathrm{Mr}$. Greville could assume, as a matter of course, that 'all the political economists' were against Lord Ashley's proposals; to-day it may be asserted with confidence that there is no single economic professor or author who would desire their repeal. The whole series of restrictive legislation, consolidated in the 'Factory and Workshop Act, I 878,' has received the heartiest possible endorsement by statesmen and economists of every school. Jevons asserts that 'this Consolidation Act is one of the brightest achievements of legislation in this or any other country.' ${ }^{1}$ The Duke of Argyll has summed up, in his Reign of Law, the general conclusion as regards this 'Jack Cade legislation.' 'No Government,' he says, writing in 1866 , 'and no Minister has ever done a greater-perhaps, all things considered, none has ever done so great a service. It was altogether a new era in legislation-the adoption of a new principle - the establishment of

1 The State in Relation to Labour, p. 52. 
a new idea." ${ }^{1}$ Those who fought Lord Ashley most bitterly made their recantations most unreservedly, and Sir James Graham, Mr. Roebuck, and Mr. Gladstone ${ }^{2}$ have borne public testimony to the utterly mistaken character of their opposition.

The late Professor Newmarch spoke for the political economists when, as President of the Economic Section of the British Association in $186 \mathrm{I}$, after referring to the progress of Factory legislation, and the 'wholly successful' issue of the limitation of hours by law, he said: 'It had consolidated society in this part of the island, swept away a great mass of festering and growing discontent, placed the prosperity of the district on a broad, solid, and safe basis, on the orderly, educated, contented labour of Lancashire, a security against foreign competition, a guarantee of power, and fund of undivided profits. These results had followed from the sagacious, persevering, and moral exertions of the advocates of the Ten Hours Bill.' ${ }^{3}$

Mr. Mundella, in the enthusiastic Preface which he wrote for the translation of Von Plener's English Factory Legislation in 1873 , speaks for the enlightened manufacturers when he tells us that he does not 'conceal his agreement with the Duke of Argyll, that "progress in political science has been in nothing happier than in Factory legislation."

Mr. Bright, indeed, remained unrepentant all his life, though even Cobden softened towards Lord Shaftesbury, and Cobden's biographer gives us his own view and the judgment of statesmen on the opposition to the principle of Factory legislation of these great apostles of Free Trade. Speaking of Cobden's preference for the latter panacea, Mr. John Morley, in words pregnant of import, asks :-

How are you to settle the mutual relations of capital and labour to one another? Abolition of restriction may be excellent in the sphere of commodities. Is it so clear that the same condition suffices for the

1 Reign of Law, ch. vii. p. 402.

2 See Hodder's Life of Lord Shaftesbury, vol. ii. pp. $205,206$.

3 Quoted in Hodder's Life of Lord Shaftesbury, vol. ii. p. 207. 
commonwealth when the commodity to be settled is a man's labour? Or is it not palpably false and irrational to talk of labour as a commodity? In other words, can the relations between labour and capital be safely left to the unfettered play of individual competition? The answer of modern statesmanship is that unfettered individual competition is not a principle to which the regulation of industry may be entrusted. There may be conditions which it is in the highest degree desirable to impose on industry, and to which the public opinion of the industrial classes may be entirely favourable. Yet the assistance of law may be needed to give effect to this opinion, because-in the words of the great man who was now preparing the exposition of political economy that was to reign all through the next generation - only law can afford to every individual a guarantee that his competitors will pursue the same course as to hours of labour and so forth, without which he cannot safely adopt it himself. 1

It will be said that Lord Shaftesbury's Factory Acts applied only to the labour of women and children, in the legal regulation of which most people are now agreed, whereas the agitation for an Eight Hours Bill aims at restricting the labour of adult men, hitherto unmentioned in Factory legislation. The assumption that the existing Factory Acts do not affect men's labour is, however, merely one of those conventional mental veils by which the Englishman loves to conceal from himself the full scope of his actions. It is equally true that the earliest Factory Act ( 1802 ) applied only to parish apprentices in cotton and woollen factories, and nothing was probably further from the minds of its supporters than its subsequent expansion into what Mr. John Morley approvingly calls 'a complete, minute, and voluminous code for the protection of labour.' ${ }^{2} \sqrt{ }$ Not until I 842 was any restriction placed on adult labour, and then only in the form of a prohibition of women working below ground in coal mines. In I 844 came an Act bringing adult women in textile factories the same protection as 'young persons.' The celebrated 'Ten Hours Bill' of I 847 still professed to limit its scope to women and young persons, but by definitely fixing their hours of commencing and quitting work, it was

1 Morley's Life of Cobden (Chapman and Hall, I88I), vol. i. ch. xiii. p. 298. The reference is to John Stuart Mill ; see infra, p. 15. (Italics added.)

2 Life of Cobden, vol. i. ch. xiii. p. 303. 
admittedly foreseen that it must have the indirect effect of similarly limiting the hours during which their associated male colleagues could be employed. It was, indeed, mainly on this ground that it was opposed by John Bright, ${ }^{1}$ and strenuously resisted by Sir Robert Peel's Government in I 844, under the circumstances described by Greville. The debate upon it in I 847 turned largely upon the admitted restrictions which it would virtuaily, though unavowedly, place upon adult male labour; and Lord Macaulay's great speech on this occasion deals almost entirely with this accusation, which he admits and justifies. The triumphant passage of the Bill into law, no less than the explicit recantation of its chief opponents, can be taken only as an admission that, upon sufficient cause shown, the actual regulation even of adult male labour is not beyond the sphere of legislative duty.

'In the thirty years that followed,' says Mr. John Morley, 'the principle has been extended with astonishing perseverance.'

The explicit regulation of adult male labour was undertaken in 1860 , when (in addition to a wide extension of the Factory Acts) a stringent code of rules was enacted for mines and miners, not indeed directed towards their protection from overwork, but towards their protection from accidents. By this time little more objection was made in point of principle, though each successive restriction was denounced as ruinous to trade. The Act of I 864 was, indeed, deliberately so framed as to prevent the adult male pottery workers from pursuing their custom of working excessive hours four days a week, and spending the other two days in idleness. ${ }^{2}$ The same Act made sanitary regulations applicable to all factories and workshops within its scope, and thus practically inaugurated the further development of the law which has taken place in the subsequent Acts, under which the adult male worker, no less than his wife, daughter, or youthful son,

1 Speeches, ch. x. p. 287.

2 Von Plener's English Factory Legislation, pp. 59, 6o. 
is in all factories, and some workshops, explicitly protected, whether he likes it or not, against insanitary conditions of employment; against accidents from unfenced machinery or gearing, or from faulty grindstones; and against fraud or oppression by his employer. The Labour Code still bears abundant marks of its tentative and empirical origin, and still refrains from formally avowing any direct interference with the hours of adult male labour, but, as Fawcett complained in the debate on the $1873 \mathrm{Bill}^{1}{ }^{1}$ its effect in reducing the hours of all the workers in the works under its operation is undoubted; and in the textile and pottery industries, in particular, the hours of male labour are almost invariably exactly those prescribed by law. The work which remains for the legislator is the extension of this principle of the State regulation of labour to the industries as yet free from its beneficent protection, and the continuance, as far and as quickly as the public opinion of the wage-earners will support, of that legal diminution of the hours of labour which (as the President of the Economic Section of the British Association was already in $186 \mathrm{I}$ able to report) has been found so 'wholly successful.'

The extension of the scope of the Acts is mainly needed in such crowded industrial agglomerations as part of East London, where the multiplicity of 'garret masters' and small workshops utterly baffles the inspector. All large factories become easily known, but the smaller places, which are often the worst, are difficult of discovery.

At present the Factory Acts apply to-(I) textile industries employing steam or other mechanical power; (2) certain specified non-textile industries, whether power is used or not $;^{2}$

1 Speeches (Macmillan, 1873), p. I26; see also Jevons's The State in Relation to Labour, ch. iii. p. 64, and Von Plener's English Factory Legislation, p. 92, in confirmation.

2 The manufacture of earthen ware, lucifer matches, percussion caps, cartridges, paper, glass, tobacco ; machinery, metal goods, india-rubber, and gutta-percha, if by mechanical power; paper-staining, fustian-cutting, letterpress printing, bookbinding; blast furnaces, copper mills, iron mills, and foundries; bleaching and dyeing works; flax scutch mills; hat works, rope-wa'ks, lace warehouses, shipbuilding yards, quarries, pit banks, etc. 
(3) workshops employing women or children; (4) bakehouses; (5) workshops employing men only; (6) domestic industries regularly pursued at home (other than straw-plaiting, pillow-lace-making, and glove-making). But the last two classes are subject only to a very few of the restrictions of the Acts, and the inspection of bakehouses has been, since I 883 , relegated to the local sanitary authorities, by whom it is usually neglected. These three classes are accordingly almost entirely unregistered, and are often practically free from any inspection or control. The result, in densely crowded industrial centres, has lately been forced upon the attention of the public by the revelations 'of the House of Lords' Committee on the 'Sweating System,' and, as regards bakehouses, by some very realistic descriptions of the unmentionable horrors among which is made the bread we eat. It is practically certain that further legislation will soon be initiated with a view to the enforcement of a genuine inspection of all these surviving 'Black Holes' of industry. What is needed is forcibly described by Mr. Charles Booth, ${ }^{1}$ in a plan for the efficient registration of East London industries, which would have delighted the heart of Jeremy Bentham. He advocates

a double system of license-a license to be taken out by the owner of any premises used for manufacturing purposes, as well as one to be obtained by all manufacturing employers. . . The object is simply to secure,the execution of the law, by making the responsibilities under it definite and intelligible, and by facilitating inspection. I imagine that on the licenses would be clearly set forth (in simple language, and not solely by means of excerpts from Acts of Parliament) the responsibilities involved. These licenses would be obtainable on application at any post-office, and be renewed annually. ... Counterfoils would be forwarded from the post-office to the factory department of the Home Office, and from these a complete directory of every employer and his place of work could be framed and revised annually. . . The responsibility under the law as to sanitation would ultimately rest with the landlord ; and as to overcrowding or illegal hours, with the employer. .. It is not, however, to the direct action of the law, backed by the

1. Life and Labour in East London, p. 498. Williams and Norgate. I889. 
imposition of fines, to which I should trust, so much as to the moral effect of inspection, publicity, and the open acknowledgment of responsibilities.

The further limitation of the hours of labour is a more difficult task, but it is one in favour of which there is a strongly growing feeling among the workers. The actual operation of Factory legislation varies, in this respect, very considerably. In textile factories and in the manufacture of earthenware, for instance, the hours of male labour appear to be regulated directly by those allowed for female labour. The large and well-organised trades in which skilled artisans are employed have now usually obtained a normal working week, varying from fifty to sixty hours, which coincides practically with that which public opinion has embodied in law for adult women-workers. In nearly all these trades, however, the benefit of this so-called 'Nine Hours Movement' has been largely neutralised by the practice of working overtime, and the normal day has become little more than a method of computing time-wages, without restricting the period of work. Still less is there any practical limit to the hours worked by men in the smaller workshop industries, whilst the scandalously long days of railway, tramway, and omnibus employés are well known. Shop assistants, if 'young persons,' have now a nominal, but unenforced, maximum of seventy-four hours per week, but there is no limit to the labour exactable from adults. It is probable that quite half the working population of London, over fourteen years of age, work for more than twelve hours per day.

It is not, of course, suggested that a universal and compulsory restriction of the hours of labour to eight per day could possibly be brought about by any one Act of Parliament, or even merely by force of law at all. An obstinate misunderstanding of any inconvenient agitation is invariably one of the outer defences of the existing order. Those who oppose the 'Eight Hours Movement' on the ground of its impracticability are usually only taking an ungenerous 
advantage of the looseness of phrase and vagueness of hope which characterise all proletarian movements, and which do not, as a rule, prevent them from having a definite and practicable object. More generous critics seek to discover what is really meant by a popular agitation, endeavouring to put into reasonable form the necessarily fluid aspirations of the masses. It may be admitted that the hours of labour in any particular industry can only be adjusted by the negotiations of those concerned in that industry, and that any uniform law is impossible. The existing Factory Acts show us, however, how a comprehensive labour code may be so adjusted as successfully to deal with hundreds of the most diverse industries; and it does not appear in any way impossible for those employed in any particular occupation to obtain definite registration in law for the conditions of employment which they desire to ensure to themselves, their colleagues, and their successors. It is now recognised that all social organisation is the product of a long series of the actions and reactions on each other of opinion and law. In matters industrial, the factor of law was, after the dissolution of the mediæval social synthesis, at first almost entirely neglected, with the result that, as one eminent economist tells us, 'we have been suffering for a century from an acute outbreak of individualism, unchecked by the old restraints, and invested with almost a religious sanction by a certain soulless school of writers.' 1 The 'true inwardness' of the Eight Hours Movement is an assertion of the necessity of the legal recognition of the general social interest in every labour contract, quite as much for the sake of the influence upon public opinion of such legal recognition, as for the immediate social advantages sought.

It is hardly necessary to dwell upon the advantages to be expected from a further diminution of the hours of labour, if this can be secured without social danger. The time has gone by when it can seriously be argued, as it was in the

1 Professor H. S. Foxwell, p. 249 of essay in The Claims of Labour. Edinburgh Co-operative Printing Co. 1886. 
last generation, that increased leisure meant for the workman increased opportunity for drunkenness, vice, and crime. 'The desirability of work for its own sake is now heard only as regards the West Indian 'Son of Ham,' or the colonial 'native' whose wide lands are coveted by the insatiable energy of the Caucasian, spreading civilisation and wageslavery all over the globe. As regards our own countrymen, at any rate, it is tacitly admitted that a 'redistribution of leisure' is well worth striving for ; that to spend the entire waking life in a factory is a kind of existence alike disagreeable and demoralising, and that the better side of life, the richest in individual self-realisation, and the most fertile in social improvement, only begins at the moment when the daily bread has already been ensured, and the bread-winner is able to turn with a free mind to those wider duties of self-culture, parentage, and citizenship, upon the due fulfilment of which social progress ultimately depends. Many thousands of workers still toil too long for even physical health; but the main plea for shorter hours has been raised to a higher plane. It is no longer merely contended that the worker cannot healthily fulfil his daily task; even where he can do so a true view of social requirements compels us now to claim for the 'lower class brutalised' some opportunity for participation in that civilisation from which their hours of toil now usually relentlessly exclude them.

Popular opinion is, however, now running so strongly in favour of a general shortening of the hours of labour, that complicated social or physiological reasoning on the point is unnecessary. Every one professes to desire a reduction in working hours, but many persons seem to think that it will be good only if it comes through the efforts of the workers themselves, organised for industrial war.

We are nowadays all in favour of trade unions, and even those who formerly talked about their tyranny being worse than that of the 'Dey of- Algiers,' apparently regard them as guardians of popular freedom in comparison with the successors of Lord Shafteshury. But trade unions are 
efficacious in proportion as the workers are strong; and to recommend them as a panacea to the weak is like the repeated injunction to Mrs. Dombey 'to make an effort.' Complacent middle-class advisers forget that fewer than Io per cent of the adult wage-workers of the country are represented in the annual Trade Union Congress, and that not 20 per cent belong to anything even professing to be a trade union, usually because no union exists in the occupations pursued by the remainder.

But even if universal Trade Unionism were feasible, its advocates do not realise that an 'eight hours day' secured by its efforts would inevitably cost, as the nine hours day did, a long series of embittered strikes and trade disputes. Now, a strike is an industrial war, and those who glibly recommend, not one or two, but a long series of industrial wars, might well consider whether even an eight hours day is worth that cost of suffering and social inconvenience. There is, however, a 'more excellent way' than war, even in industry; and just as the 'King's peace' has superseded the rough struggle of the highway, it may be hoped that debates at Westminster or in the town council will replace the 'arguments' of the pickets and the 'arbitration' even of the 'Great Cardinal.' This is now, though few are aware of it, the 'orthodox' economic view.

I see nothing, therefore (said Jevons in 1882 , referring to the incipient agitation for an Eight Hours Bill), to forbid the State interfering in the matter, if it could be clearly shown that the existing customs are injurious to health, and that there is no other probable remedy. Neither principle, experience, nor precedent in other cases of legislation prevents us from contemplating the idea of State interference in such circumstances. ${ }^{1}$

The principal objection urged by those who desire an eight hours day, but oppose an Eight Hours Bill, is that the latter would weaken the spirit of self-reliance which distinguishes the English working man. But this is surely the most fanciful of theoretical objections. No evidence is

1 The State in Relation to Labour, p. 65. 
adduced to prove that the self-reliance of working men has been diminished by the long series of Factory Bills already passed into law. No suggestion is made that women workers in trades which are under effective legal protection are less self-reliant than those who toil in the unregistered laundries of Notting Hill, or 'sweating dens' of East London. The cotton operatives of Lancashire, both male and female, have been longer and more thoroughly subjected to the enervating influences of the legal limitation of their hours of labour than any other workers; it will be news, to those who know them, that they are less self-reliant than less effectively protected wage-slaves, or that they possess less sturdy independence than their unprotected forefathers of seventy years ago. The actual evidence is, in fact, to exactly the contrary effect. Mr. Mundella is the best possible witness on such a point, and his testimony is emphatic. Writing in 1893 , he says $:^{1}$

An argument which is freely advanced against the interference of the State with the relations of capital and labour, is that it tends to undermine the independence and self-reliance of the class which it seeks to protect, and teaches them to look to the State rather than to their own exertions to remedy evils requiring redress. My answer to this is that the factory operatives of Lancashire and Yorkshire have made greater advances in self-reliance and independence during the past fifty years than any other class of English operatives. Building and benefit societies, co-operative associations, both for distribution and production, have taken their rise and flourish amongst them on a scale of magnitude unknown in any other part of the United Kingdom.

It may, moreover, be added that no class of wage-earners is better organised, and that their unions have become stronger since the Ten Hours Bill became law, and not weaker. The objection is, however, not merely contrary to fact; it has not even the flimsy warrant of theoretic validity. It is a survival from the time when 'the Government' was an oligarchy practically free from popular control. When 'the Government' is obviously something outside of, and distinct from, the people themselves, any boon obtained from it might

1 Introduction to E. von Plener's English Factory Legislation, p. viii. 
conceivably have the effect of weakening the self-reliance of the recipients. But now that 'the Government' is becoming more and more regarded merely as the executive and administrative committee of the people, it is difficult to see how their own gift to themselves can have any such result. A cricket club may be demoralised by being presented with a set of stumps by the Parliamentary candidate for the borough, but if these are bought out of the members' own subscriptions by the members' own elected committee, no member feels otherwise than strengthened in his self-reliance. The Cabinet and the House of Commons, not only are nothing but the executive committee of the people, but (what is in this connection more important) they are daily becoming more generally recognised as such. How the registration of a trade agreement by law, at the instance of the majority of the workers in the trade, could, under any circumstances, possibly weaken their self-reliance, or lessen their sturdy independence, even Mr. Bradlaugh was never able to explain.

It is also objected that it is not the business of Government to regulate the hours of labour. Those who make this objection have perhaps some absolute test by which they can determine what is, and what is not, the business of Government. The great writers on the subject have no such ready rule. Bentham had none but expediency-the very point at issue. John Stuart Mill, diligently seeking such a rule when writing On Liberty, could find nothing more definite than this general expediency, and, indeed, incidentally recognises the admissibility of legal restraints on the employment of adult labour. ${ }^{1}$

It may, indeed, be contended that the prevention of excessive hours of labour is one of the essential duties of Government in an advanced industrial community. Even on the 'glorified policeman' theory of 'administrative nihilism,' it is universally admitted to be the primary duty of Government to prescribe the plane on which it will allow the

\footnotetext{
1 See pages 53 and 56 of 1878 edition.
} 


\section{6 The Regulation of the Hours of Labour}

'struggle for existence' to be fought out. Of course, the 'fittest' to survive under the given conditions will inevitably survive, but the Government does much to determine the conditions, and therefore to decide whether the 'fittest,' by the test of conflict, shall be also the 'best' then and there possible. We have long ruled out of the conflict the appeal to brute force, thereby depriving the strong man of his 'natural' advantage over his weaker brother. We stop, as fast as we can, every development of fraud and chicanery, and so limit the 'natural' right of the cunning to overreach their neighbours. Notwithstanding cries of 'caveat emptor,' we prohibit the weapon of deceptive labels and trade-marks. In spite of John Bright's protest, we rule that adulteration is not a legally permissible form of competition. We forbid slavery: with Mill's consent, we even refuse to uphold a lifelong contract of service. The whole history of Government is, indeed, one long series of definitions and limitations of the conditions of the struggle, in order to raise the quality of the fittest who survive. This service can be performed only by Government. No individual competitor can lay down the rules for the combat. No individual can safely choose the higher plane, so long as his opponent is at liberty to fight on the lower. 'Gresham's Law,' according to which bad currency drives out good, applies throughout the industrial contest. The 'good' employer is liable to be ousted by the bad, and, as is now explained, the honesty which is the best policy is merely just so much honesty as will not let you fall flagrantly out at elbows with your neighbours. If sixteen hours in the gas-lit basements of the London textile warehouses is the standard of the trade for growing lads, apparently not even a Samuel Morley could venture to work his staff shorter hours. No cotton factory will dare to work only eight hours while its rival works ten. No shop dare close while its competing neighbour remains open. It is for the people collectively to decide whether the industrial tournament shall be fought à l'outrance, or shall be merely a friendly emulation, not 
involving wounds, degradation, and death even for the vanquished. A hundred years ago the 'fittest' to survive were sturdy Virginian slaves; sixty years ago they were the maimed, distorted, and diseased factory hands who paraded before Lord Ashley in Oldham and Blackburn; a generation ago they were the 'lower class brutalised' of the great apostle of culture-what they will be a generation hence depends essentially upon the legal and social limitations which we to-day set to the 'ape and tiger' of the 'natural' man.

The case is not one of personal liberty in self-regarding acts. No one wishes to prevent a man from working, as long as he pleases; the community merely claims the right to prevent him from selling his excessive labour in such a way as to cause other workers to be compelled to work as long as he does. No one is to be coerced for his own supposed advantage, but only for the sake of others, in cases where his pursuit of that advantage operates so as to limit the industrial freedom of his fellows. The principle of individual liberty, as Mill expressly points out, cannot legitimately be pleaded against the 'jurisdiction of society' in such cases; the only question for discussion being, as he says, whether the proposed legislation will produce the effects desired. $^{1}$

Both Liberal and Conservative statesmen agree that the amendment and the extension of the Factory Acts are urgently needed. Factory legislation has, indeed, never been a party matter, and, whilst the Tories passed the earlier Acts, it was a Whig Ministry which actually made the 'Ten Hours Bill' law, and a Conservative Home Secretary who carried the great consolidating Act of I 878 . No question of principle really remains at issue, and the important task of to-day is to clear up the misconceptions which hinder popular unanimity on the subject, and to devise means for the practical application of the admitted

1 On Liberty, p. 56 (cheap edition, 1878); see also Jevons's The State in Relation to Labour, p. 65. 
principles to the complicated circumstances of modern industrial life. What the situation, in fact, demands, is a definite measure for practical discussion.

With the view of meeting this want, a detailed and practicable 'Eight Hours Bill' was, in I 889, drafted by a committee of the Fabian Society, which was pronounced by high official and industrial authorities to be thoroughly 'workable.' 1

After preliminary clauses, the draft defined the normal day and week in all contracts for the hire of labour, where it is not otherwise specified, as being respectively eight and forty-eight hours' working time. Such a clause would have but little direct effect, as it would always be possible for either party to the contract to stipulate for longer hours, but it would be useful as expressing the collective judgment of the community as to what constitutes the limit of a 'fair day's work.' There can be no economic or juristic objection to a legal definition of the implied conditions which the law will import into a contract, and similar implications are already abundant in our legislation. Various American States, such as California, Illinois, New York, and Wisconsin, have, indeed, already made this clause law.

The draft Bill then proposed to enact that the hours of employment in all branches of the national or local civil administration shall, except in cases of emergency, be restricted to eight per day. There can be no doubt as to the ethical right or political power of the majority of the community to determine. the conditions upon which their public servants shall be employed, and if the popular voice demands that the State should set a good example as an employer of labour, even at popular cost, this will be a sign of the quickening of the public conscience which no one need regret. That the Government should set some kind of example is an inevitable consequence of its existence as an employer of labour, and nothing but good can result from an improvement in the example which it sets.

1 An Eight Hours Bill, in the Form of an Amendment of the Factory Acts, (Fabian Tract, No. 9). 
The next two clauses provided for the limitation of hours of workers on railways and in mines, with proper exceptions and safeguards. Little question can arise among ordinary practical men as to these cases. The most ardent advocate of liberty will be impressed by the public danger involved in the present excessive hours of railway servants, and, as already mentioned, even so stern and unbending a politician as Mr. John Morley has given in his adhesion to this part of the 'Eight Hours Movement.' The public interest in the matter has, indeed, now been asserted in the Railways Regulation Act of I 895. Public opinion appears also strongly to favour the legal limitation of the hours of underground labour. At present youths of fourteen often work ten and twelve hours in the mine, and even the wellorganised coal-miners proper have been unable appreciably to reduce their hours in the West of Scotland, in the South of England, and in Wales. They are nevertheless practically unanimous, everywhere but in Northumberland and Durham, in their desire for an 'eight hours day,' at whatever risk of loss of wage. Their representative national assembly has repeatedly voted in its favour. The Trade Union Congress every year adopts an Eight Hours Bill for miners with practical unanimity. A clause to this effect was actually proposed in Committee on the Coal Mines Regulation Bill as long ago as I 887, and a Miners' Eight Hours Bill passed its second reading in the House of Commons in 1893. Legislation on the point is clearly near at hand.

Other clauses proposed to give to the County Council, or other suitable local authority, the power to make byelaws-(I) regulating the employment of labour in connection with local monopolies of services of a public nature ; (2) providing for the universal registration of workshops, advocated by Mr. Charles Booth for special localities; and (3) dealing with the sanitary condition of places where persons are employed for hire. This power to make byelaws, subject, in all cases, to confirmation by a Cabinet Minister, and to revision, if necessary, by a court of law, is 
already widely used, and it affords a convenient method of dealing with the special circumstances and requirements of different localities.

The clause applying to industries generally was, however, of greater importance than those hitherto mentioned, and as the idea of 'trade option' which it embodied was somervhat of a novelty, the draft clause is given in full :-

Where it is proved to the satisfaction of a Secretary of State that a majority of the persons employed throughout the United Kingdom in any one trade or occupation are in favour of the maximum hours of labour per week in that trade or occupation being fixed by law, or, if already so fixed, being altered by law, he may by order made under this part of the Act declare a maximum number of hours per day or per week for such trade or occupation, and after the expiration of three months from the date of publication of such order any person employed in contravention thereof shall be deemed to be employed in contravention of this Act, and the person so employing him or permitting him to be so employed shall be liable on conviction thereof to a fine not exceeding ten pounds for each such contravention.

A Secretary of State shall have power, in order to satisfy himself of the desire of the persons employed in any trade or occupation as aforesaid, to cause a public inquiry to be held in the principal district or districts in which such trade or occupation is carried on, or to cause a poll to be taken of the persons employed in such trade or occupation, or to take such other means as he may deem fit.

For the purpose of this section, persons employed in any trade or occupation shall be taken to mean all persons employed for hire, or actually performing labour, in any capacity in such trade or occupation, whether already subject to the provisions of the Factory and Workshop Act 1878 , or of this Act, or not.

No order made in pursuance of this section shall declare a maximum number of hours of labour per week in excess of sixty or fewer than forty-five.

It shall be the duty of a Secretary of State to institute an inquiry, in such manner as he may deem fit, with a view to the consideration of the expediency of making an order under this part of the Act, in each of the following cases, viz.-

(a) Whenever he shall have reason to believe that excessive hours of labour prevail in any trade or occupation;

(b) Whenever he shall be requested to do so by the committee or other executive body of any duly registered trades union, or, in the case of there being no duly registered trades union in the trade or occupation in respect of which the application is 
made, by the committee or other executive body of any trades council, trades union congress, or other association or federation of trades unions.

Provided that a Secretary of State shall not, unless for some special reason approved by himself, institute any such inquiry within a period of twelve months from the date of the holding of any previous inquiry in respect of the same trade or occupation.

This clause would meet the cases dwelt upon by John Stuart Mill ${ }^{1}$ and Professor Henry Sidgwick, ${ }^{2}$ and specially instanced, as we have seen, by Mr. John Morley, where the adoption of shorter hours would manifestly be advantageous if it were adopted by all the persons concerned, but where the opposition or disloyalty of a minority nevertheless prevents the desire of the majority being carried into effect. In such a case, as Mill points out, "What some did from choice, others would soon be obliged to do from necessity, and those who had chosen longer hours for the sake of increased wages would be forced in the end to work long hours for no greater wage than before.' It is on similar grounds that the legislation of most civilised countries continues to forbid the pursuit of the main processes of labour on the weekly day of rest, and it may surprise some individualist fanatics to learn that this immemorial restriction upon adult labour, which was effectively cited by Macaulay in his great speech on the Ten Hours Bill, ${ }^{3}$ received the express support of John Stuart Mill, even at the moment when he was writing his plea for individual liberty. ${ }^{4}$ In such cases the legal endorsement of the will of the majority is, indeed, the only means of protecting that majority from having to submit to the will of the minority. The law, as Mill saw, increases the aggregate freedom instead of diminishing it.

Under the proposed system of 'trade option,' a legal limitation of the hours of labour in any trade could not

1 Principles of Political Economy, last edition, I865, book v. ch. xi. sec. 12.

2 Political Economy, book iii. ch. ii. p. 422 . I 883 .

3 Lord Macaulay's Speeches, p. 444. Longmans. 1854.

4 Mill's Liberty, p. 53 (cheap edition). 
practically be put in force until after a thorough discussion of the question among all those engaged in that occupation; nor until a considerable majority were either decidedly in favour of the limitation, or quite willing to acquiesce in it. A further advantage would be that the boys, labourers, casual 'hands,' and other unorganised workers connected with each large industry, would share in the decision and benefit by the limitation, equally with the so-called 'aristocracy of labour.'

The 'Trade Option' Bill of the Fabian Society found a great deal of support, among workmen and legislators alike. The Trade Union Congress of 1892 (Glasgow) adopted the principle, but turned it inside out by voting that the law should apply to all trades except those which made a special demand to be exempted from it. This new proposal was called The Trade Exemption Scheme. The Fabian Society then appointed another Committee to draw up a Trade Exemption Bill, so as to meet the views of the Trade Union Congress. The Committee did the best it could. but had to report that the working of Trade Exemption would be too expensive, troublesome, and complicated to be practicable, and that both Option and Exemption were, in their naked simplicity, unsound in principle. A subsequent Committee proposed a new scheme, called Trade Inquiry, which stands as the most practical solution of the problem that has yet been propounded.

The difficulty to be overcome is that almost every industry requires a separate set of regulations, but, piecemeal legislation, dealing successively with every trade in the country, is utterly beyond the capacity of the House of Commons. There is only one way out of the dilemma; and that is to pass a general Act providing for piecemeal regulation. We must establish by law an administrative body whose business it shall be, without giving further trouble in Parliament, to draw up such regulations for each trade as shall secure to the workers in it the benefit of an eight hours working day. A practicable Eight Hour Bill 
must include the constitution of such a body-let us call it an Eight Hour Commission. Further, it must be capable of being put into operation promptly, and of being adapted to the requirements of all the various trades. And it must, of course, conform to the general principles of democratic legislation by making the welfare of the whole community paramount. Private interests and trade interests, whether advanced by J abour or Capital, must not be accommodated at the expense of national and international interests.

The Fabian Society accordingly proposes ${ }^{1}$ that the Home Secretary (pending the creation of a Minister for Labour) should be compelled to hold an inquiry into the duration of the hours of labour in a trade or industry (a) when directed to do so by either House of Parliament; (b) when requested to do so by a County Council, a Town Council, a duly registered Trade Union of the trade, or a Trades Council where there is no union; $(c)$ on a special report from an Inspector of Factories. For the purposes of such an inquiry the Home Secretary would be bound to appoint a Commission of three persons, one of them a Factory Inspector, and one a woman in the case of trades employing women. The inquiry would embrace all trades directly dependent on the one mainly in question. The Commission would have full powers to examine witnesses on oath, to compel the production of time-books and other documents relating to the hours of labour, and to inspect factories and workshops. In order to ascertain whether the workers in a trade were in favour of a reduction of their hours of labour, the Commission would have power to take a vote by ballot of the employees in the factories and workshops concerned; or it might proceed by holding public meetings, or by calling witnesses.

At the conclusion of the inquiry, the Commission would. have to report ( $a$ ) what appeared to be the prevalent opinion among the members of the trade or industry as to the reduction of their hours of labour by law ; (b) the probable

1 Eight Hours by Law: a Practicable Solution (Fabian Tract, No. 48). 
effect of such reduction on the trade or industry and the community; (c) what reduction of the hours of labour in the trade or industry was desirable, what should be the length of the working day and week, and what allowance should be made for emergencies, seasons, etc.; $(d)$ whether the case was a suitable one to be dealt with by the local authorities of the districts affected by the trade or industry. The report, together with those parts of the evidence which were not confidential, would be printed and laid before Parliament.

Within three months after the presentation of the report, the Home Secretary would be bound either to report to Parliament his reasons for taking no action, or, if he determined to take action, to draw up an Order containing either (a) regulations prescribing the length of the working day and week, with such exceptions as he might deem advisable for emergencies, seasons, etc.; or (b) conferring upon County Councils and Town Councils in defined districts the power of regulating the hours of labour in the trade within limits specified in the Order. The Order, of either kind, would be laid before Parliament, and after the lapse of forty days would become law, unless the House before the expiration of that time presented an address to the Crown against the Order or any part thereof. No request to vary or revoke an Order, or for a second inquiry after an Order had been refused by the Home Secretary, would be admissible until the expiry of one year from the date of the Home Secretary's report to Parliament. The same process of inquiry by a Commission would have to precede any fresh decision by the Minister. ${ }^{1}$

1 The object of the Inquiry procedure is to get a continuous process of legislation without perpetual application to Parliament. The method suggested is a development of the practice of regulation by Provisional Orders which forms so large a part of modern law-making. These orders come into operation either after being legalised by an Act of Parliament, or, without express Parliamentary confirmation, after being before both Houses for a given time and not being objected to either by resolution or address to the Crown. The Endowed Schools Acts, the Factory Acts, and the Local Government Act, I 888, contain specimens of the procedure. Under the Factory Act, the Home Secretary has discretionary 
The local authorities specified in an Order of class (b), or any of them, would be permitted to combine together for the purposes of the Order. Before a bye-law adopted by a local authority for the regulation of the hours of labour in a trade became law, it would have to be submitted to the Home Secretary, in order that he might see that it complied with the terms of his Order. Before a local authority could vary such a bye-law, it would have to receive power to do so by a fresh Order.

Legislation of this kind may be deemed inexpedient, but no one can deny that it is quite practicable of execution, without appreciable danger from foreign competition, or any departure from principles or precedents already adopted. Depending automatically, as each step does, upon the support of a majority of the workers, no step could be made in advance of the public opinion which alone can make laws of this kind effective. All that is asked is that law should not too far lag behind opinion.

If convinced, however unwillingly, of the practicability of the reform, objectors often repeat the arguments used against every successive Factory Act, in saying that a shortening of the hours of labour will necessarily involve a diminution of wages, a fall in profits, a rise in prices, and the loss of the export trade. Each of these dire prophesies really contradicts all the others, but that does not usually prevent them from being promulgated simultaneously or alternatively by those hasty oracles who are ever ready to rush in where instructed political economists fear to tread.

The economic effects of a general limitation of the hours of labour are, it must be admitted, by no means simple; and members of Parliament may not unreasonably complain that those 'chaplains of the middle-class,' the University professors of political economy, have abandoned them to

power to prescribe by Order the hours between which persons engaged in various occupations are to work; to determine whether certain classes of workers are to be allowed to work at night; and to exclude certain industries altogether from the Act. 
the Democratic wolf without any explicit teaching on the subject. Nor can the problem be safely decided offhand, as is the fashion of the casual objector, ignorant alike of Longe and Thornton's demolition of the 'wage-fund theory,' and of the paradoxical results of Ricardo's 'Law of Comparative Cost' in international trade. The problem is not merely one of wages or of product, but also one of profits, interest, the rate of accumulation, price, the limitation of demand, and international values.

It is difficult to predict whether and to what extent the aggregate gross product of commodities and services would be lessened in quantity or quality by a general reduction of the hours of labour. So far as positive evidence goes, the presumption is against any such diminution. The successive reductions of the hours of labour which this century has witnessed, have been.attended, after a very short interval, by a positive general increase in individual productivity. In many cases it has been found that the workers did more in ten hours than their predecessors in twelve. The effort to get more than a certain amount of work out of a man defeats itself. Even if an increase in quantity can be dragged out of that terrible 'last hour' immortalised by Senior and Marx, it is often at the expense of the quality of the whole. And the speed of work lessens as the day advances.

In other instances it has been found possible to increase the speed of the machinery as the working hours were lessened, and there can be little doubt that this would often follow a further reduction. Moreover, a reduction of hours to eight per day would enable one intermission for a meal to be dispensed with. An 'eight hours day' needs, for adults, only one break, and every employer knows the loss of time, slackening of speed, and weakening of energy which every break produces.

Nevertheless, it is probable that in many occupations a net falling off would occur in the quantity of product produced per day per head, not adequately compensated for by 
any improvement in quality. It is, indeed, possible that a small reduction in average productivity per head might take place throughout the whole community. But this would by no means imply any diminution of the aggregate product. The first effect of any such diminished productivity would be an increase in the number of workers. If the reduction of hours resulted in a diminution of the number of the 'unemployed,' who are obviously now maintained at the expense, one way or another, of the 'employed,' the aggregate product of the community might even be increased. And this, which on the whole appears to be the probable result, necessarily implies, for the reasons above stated, a positive increase in the aggregate productive power of the community. In the arithmetic of labour, as in that of the Customs, two from ten might leave, not eight or nine, but even eleven.

Nor can it be assumed, as a matter of course, that wages would fall.

When precisely the same argument was used against the Ten Hours Bill, Macaulay made a proper protest against any such hasty assumption.

'I am surprised,' he said, 'when I hear men of eminent ability and knowledge lay down the proposition that a diminution of the time of labour must be followed by a diminution of the wages of labour, as a proposition universally true, as a proposition capable of being strictly demonstrated, as a proposition about which there can be no more doubt than about a theorem in Euclid.' 1

We know now that, in this particular case at any rate, Macaulay was right in his doubt. The hours of labour in textile factories have been successively reduced from about 90 to $56 \frac{1}{2}$ per week, while the rate of wages has uniformly risen. Nor has the gain been made at the expense of other industries. Political economists are emphatic in their conclusion' that 'the effect of the Factory Acts has been 
undoubtedly to raise the real wages of the working classes as a whole.' 1

The notion of the inevitability of a fall in wages on a diminution of the working day derives its force partly from the surviving superstition of a determinate 'wages fund,' incapable of increase, however many additional workers are taken on, and partly from the apparently obvious results of ' piece-work.' Where workers are paid by the hour or by the piece, a diminution of hours must, it seems at first sight, diminish their earnings. But every economist now knows, as Karl Marx first conclusively illustrated, that wages by the hour or by the piece in any particular trade and locality really follow the same course as contemporary wages by the day. The daily earnings of an average piece-worker tend to be identical with those of an equivalent worker for day wages, and the effect upon day wages generally is clear. Every employer admittedly expects to have to pay more in wages, and hence the bitter and persistent opposition of the spokesmen of this class to each successive restriction upon the hours of labour. If wages were really expected to fall in proportion to the shortening of hours, the employer would have but little motive in resisting the shortening; and no motive at all if he worked his labour in shifts.

It is, however, sometimes objected that this rise in wages would be counteracted by a diminution in demand for labour, due either to diminished production, or to a rise in price. We have seen that the assumption of an aggregate diminution of production is an illegitimate one, and that even an increase might conceivably be looked for. This fact of itself implies the maintenance of the aggregate 'demand.' As Cairnes points out, 'The total demand of a community would, under such circumstances, be represented by. all the commodities and services there offered in exchange for other commodities and services; and these would also constitute

1 Article on 'Wages,' by Prof. J. S. Nicholson, Ency. Brit. vol. xxiv. p. 3II (1888). 
the total supply in that community.' 1 And, as Cairnes expressly added with regard to a universal 'Nine Hours Movement,' 'Why should it affect the relations between commodities in general and money?' Even granting, however, that some commodities might rise in price, the rise would, ex hypothesi, merely equal the increased amount paid in wages, so that, in the worst possible case, the 'real wages' of the whole wage-earning class could not be less than before. It is, however, almost certain that the necessary absorption of a large portion of the 'reserve arm of industry,' the unemployed and the partially employed, would so strengthen the power of labour in its negotiations with the employer, as to enable it to obtain even a rise in real wages by an 'Eight Hours Bill.' That this has been the result of previous Factory Acts is undoubted. If the wage-earners press for such a measure, and are willing to risk its effect on wages, it is, at any rate, not for any other class to resist them on this ground.

The effect upon prices of a general shortening of hours would be complex. If, indeed, the wages of labour entered equally for all commodities into the manufacturers' expenses of production, the result would be, as we shall see, in the nature of a 'general tax on profits,' and would not affect relative exchange-values or prices at all. This has been thoroughly worked out by the economists, and the reader may be referred to any manual on taxation ${ }^{2}$ for a further elucidation of the results of such a tax. But a universal reduction of the hours of labour, so far as it resulted in increasing the expense of manufacturing at all, would be analogous to a tax on all commodities equal to the increased expense, or to a general rise in the cost of labour to that extent. McCulloch worked out this problem for us $^{3}$ in a manner which still holds good. To equalise the expectation of profit, as Mill sums it up, the value of the commodity

1 Some Leading Principles of Political. Economy, p. 27. Macmillan. I874.

2 See, for instance, Mill's Political Economy, book v. chap. iii. sec. 3 .

3 Principles of Political Economy, part iii. sec. iii. sec. 2 ; see Mill, book v. chap. iv. sec. I. 


\section{30 The Regulation of the Hours of Labour}

into which the cost of labour enters more than it does in others, must rise, and the corresponding alteration in relative demand probably implies a relative fall in the values of other commodities less affected by the change. There would be, as Mill points out, neither a general rise of values nor of prices, but a disturbance of both, some values rising and others falling.

It may equally be safely inferred that an alteration in the hours of labour would not necessarily affect the total exports. If some values were raised and exports checked, others would be lowered and exports encouraged. , But even if the expenses of production of all commodities were raised, and with them their prices, it may be shown that the total exports would not be reduced. This apparent paradox depends on the conditions determining international values, which, first elucidated by Torrens and Ricardo, have been accepted and developed by (to name only English authorities) Mill, Cairnes, Jevons, Professor Sidgwick, and latterly by Professor C. F. Bastable, whose work on the subject should be consulted. Briefly summed up, the theory amounts to this, that international trade does not depend on the superiority of one country over another in relative expense of production, but upon the existence of differences between the relative advantage (or even disadvantage) possessed by either country in producing various classes of its own commodities. According to theory, 'England might import corn from Poland and pay for it in cloth, even though England had a decided advantage over Poland in the production of both the one and the other.' ${ }^{1}$ This paradoxical result actually happens in fact, and we find ourselves profitably exporting cotton goods to America, woollens to Australia, knives to Sweden, and copper kettles to New South Wales, although these could all be produced with less labour on the spot. During the Australian gold fever, Ireland actually sent butter to Victoria, and it would almost have paid for Melbourne to have got its washing

1 Mill, Political Economy, book iii. chap. xvii. sec. I. 
done in London. They could produce all these things actually cheaper than we do, but as they can produce other commodities to even greater advantage, they prefer, in spite of hostile tariffs, to do so. -

Hence the paradox, that our export trade does not depend on being able to produce more cheaply than our neighbours; and England to-day freely imports locomotives from Belgium, wooden frames from Germany, and 'notions' from America, although these could all be produced, remembering the labour of carriage, with much less labour here. Bermuda supplies New York with the finest possible early potatoes, but actually imports from New York other potatoes for its own use rather than grow them. In each case these imports are paid for by the export of some commodity in which the advantage in production is greater. We weave our wheat on Rochdale looms, grind our meat on Sheffield stones, and hew our wool in Durham coal-pits, not necessarily because we can work these industries to greater advantage than our neighbours, or because we cannot produce the imported commodities, but because we can weave, grind, and mine to greater advantage than we can produce food. It is the English farmer, not the American cotton spinner, who is really competing with Lancashire.

If the cost of labour entered in equal proportion into the expense of production of all commodities, no shortening of hours or rise of wages would affect the relative advantage of one occupation over another, and, accordingly, this would also have no influence whatsoever on our international trade.

Any alteration in the export trade which the resulting disturbance of values would actually cause (owing merely to the varying extent to which different industries would be affected) would be merely an alteration in the proportion in which the aggregate of exports was made up. The total export trade could not thereby be affected. This conclusion may be derided by the practical man, but it is, at any rate, the unanimous judgment of economists. What the practical man fears is a rise in general time wages, and to use the 
words of Cairnes, 'A rise or fall of wages in a country, so far forth as it is general, has no tendency to affect the course of foreign trade.' 1

Turning, however, to such considerations as the ordinary man prefers to any but his own economic reasoning, it may be contended that a gradual widespread shortening of the hours of labour would not be likely to affect our export trade-(I) because former similar reductions have not done so: the textile exports, especially, having enormously increased; (2) because, even now, the English cottonspinner works fewer hours than his foreign competitors, and finds their competition keenest where their hours are shortest (as in Massachusetts), not where they are longest (as in Russia and India); (3) because it has been theoretically predicted and empirically proved that the reduction would not affect prices generally; and (4) because other countries are all rapidly increasing their factory legislation also. Moreover, in countless industries there can be no question of foreign competition. In the railway industry, and other internal transportation; in the building and engineering trades; in baking, butchering, the supply of milk, and various other commodities; in the theatrical and newspaper industries; in all the forms of artistic or personal service, and in innumerable other departments of the industrial army there need be no fear of foreign competitors.

Seeing that the cost of labour does not enter equally into the price of commodities, a general increase in that cost would, as we have seen, cause a 'disturbance of values,' raising some and lowering others. Hence, there may arise, in the cases where prices are raised (i.e. in trades using relatively little machinery and inexpensive raw material), a diminution in the demand for certain commodities, either for home consumption or for export. As the aggregate production or aggregate export trade need not fall off, this does not imply any net reduction in demand for commodities or for labour, but it does imply a shifting of that demand.

1 Some Leading Principles of Political Economy, p. 400. 
In some cases the commodities which have become dearer will cease to be consumed, and the amount formerly expended on them will be devoted to other purchases. Some shifting of labour might therefore have to take place, but there is little reason to suppose that the diminution in any one occupation would at any time be more than the increased demand for labour, due to the shortening of hours.

In some instances, however, the trade might be absolutely extinguished. It is possible that several of the minor industries of the East End are absolutely dependent upon the fact that a low type of 'sweated' and overworked labour is employed at starvation wages. It is possible that the commodities so produced would not be worth having at all unless at the low price made possible by this 'white slavery.' In such a case, the extinction of the industry is the social price to be paid for the improvement of these workers' condition. The cheapness of their product is the price of blood, and the Democracy may be trusted to want none of it. Our forefathers forewent slave-grown sugar, and the New Englanders gave up taxed tea, for ulterior social ends. We can at any rate do without farthing toys, or penny puzzles, if this is necessary to heal the spreading social ulcer of East End degradation.

But what, it may be asked, is to become of the workers employed in these wretched industries: will they not be worse off than before? In no wise. The notion that labourers depend for their employment on work being 'found' for them is a widespread, but stupid, fallacy. The money hitherto spent on these blood-stained commodities, the capital hitherto employed in their production, and the labour devoted to their manufacture, would alike be transferred-mediately, if not immediately-to other industries. The necessity for increasing the staff in all industries, which a reduction of hours would probably involve, would at once enable these workers to be absorbed, possibly at higher wages, and certainly under better conditions, than they had hitherto enjoyed. 
Where, then, it may be asked, will the pecuniary loss due to a shortening of the hours of labour really fall? It cannot be admitted that any general loss will necessarily take place, but if such a diminution in the nation's annual production should actually occur, it would fall upon profits. The new Factory Act would have imposed a new restriction upon industry analogous to a general tax on profits, and such a tax cannot be shifted either upon the wage-earner or the consumer. Profits, in the ordinary sense, are made up of interest on capital, insurance against risk, and the wages of management. The two latter items would not be affected, and the whole result would be seen in a diminution of interest on capital.

It is practically certain that a tendency to a reduction in the rate of interest on capital was one of the main economic results of the previous Factory Acts. The gradually increasing restrictions co-operated with the increased competition to reduce the 'thousands per cent' which made the fortune of Lancashire to the normal rate of manufacturing profit now enjoyed. The nameless iniquities of the 'white slavery' may be presumed to have been pecuniarily profitable to the factory slave-masters, and every restriction of them was, at any rate, denounced as a confiscation of a part of the capital invested in the mills. Even as late as 1844 , as we have seen, Sir James Graham and the capitalist press were raising the cry of 'Jack Cade' against Lord Shaftesbury. The rate of loan interest, being the measure of the marginal effectiveness of capital, tends to fall with every limitation or restriction which is placed upon the employment of capital. As one profitable sphere of employment after another is forbidden, whether the slavetrade, slave-breeding, lotteries, the keeping of gambling hells, or baby-farming, new openings must be found for the use of capital, or its effectiveness at the 'margin of utilisation' inevitably falls, implying a corresponding fall in the normal rate if local interest. If any general economic loss has followed the present restrictions, this is where it has 
fallen. If any pecuniary loss is involved to the community in a further shortening of the hours of labour, it is the recipients of interest and dividends who are likely to have to bear it. The distribution of the nation's income will have been altered so that (for less work) the wage-earners receive as much as before, and the capitalists a reduced amount. All interest will be affected. A future Goschen might conceivably even thereby be enabled further to reduce the interest on Consols. A similar rise in the ' margin of cultivation'. of 'land,' especially mines, quarries, etc., may, at the same time, slightly diminish the aggregate ' rent' of immovable capital, though this will almost certainly be masked by increasing urban developments.

Such a fall in the rate of interest would formerly have been thought inevitably to lead to a slackening in the rate of accumulation of capital, and so to a renewed rise of interest. No effective encroachment, in the view of the older economists, could possibly be made on the tribute of interest, as any diminution thereof automatically brought about a subsequent increase, either through slackened savings or investment abroad. This obsolete theory is, as usual, still current in the minds of ordinary men and of leader writers, but the economist himself knows it no more. Professor Marshall tells us ${ }^{1}$ that most men would save as much if the rate of interest were lowered as they do now, and the uniform experience of the savings banks all over the world confirms this view. Professor Sidgwick, moreover, tells us that he is 'aware of no adequate empirical reason for supposing, with Mill, Cairnes, and others, that the rate of interest in England at the present day is very near the minimum point, ${ }^{2}$ below which it could not fall without causing a diminution of capital.

The question of a possible emigration of capital is more intricate, but it may be observed-(I) that the rate of loan interest in England is uniformly lower than elsewhere, and

\section{Economics of Industry.}

2 Principles of Political Economy, p. 29r. 


\section{The Regulation of the Hours of Labour}

yet the emigration of capital which has hitherto taken place has been a mere overflow of surplus annual savings; (2) that quite nine-tenths in value of what is called capital is absolutely incapable of emigration; and (3) that other nations are increasing their factory legislation parallel with our own advance, so that the gap is not by any means widening. The notion of any important emigration of capital in consequence of an Eight Hours Bill appears, indeed, as chimerical as the same threat proved to be in the cases of the Ten Hours Bill and the general Nine Hours Movement.

To sum up the probable economic results, as far as they can be discerned, a general shortening of the hours of labour may slightly decrease the average productivity per worker, but will, by absorbing a part of the unemployed, probably increase the total production of the community; supply, and therefore demand, will, in the aggregate, not be diminished; no effect will be produced upon prices generally, but some variations up and down may take place in the prices of some particular commodities; some industries may, therefore, be diminished, whilst others are increased; some few products may no longer be worth producing once the labour employed is properly treated; wages generally are more likely to be raised than lowered, though it is possible that they may remain stationary, or even droop, in a few minor industries; the aggregate payment in wages will almost certainly be larger, and that for interest on capital smaller, than before; the total export trade will almost certainly not be affected, though it may be somewhat varied in its composition; and the main permanent results are likely to be a rise in 'real time wages' and a fall in the normal rate of loan interest.

But even these economic consequences of a sudden and universal shortening of hours, whether by law or by trades union pressure, are not at all likely to ensue in any perceptible manner upon the gradual and impartial shortening which is all that is proposed. In industrial organisation 
any sudden change, however good, produces a serious dislocation, but almost any gradual change, however important, can be endured without social injury. Time is of the essence of the matter.

The political economist will, therefore, have little hesitation in following Newmarch and Jevons (not to mention Karl Marx) in thinking that the economic results of factory legislation are to the benefit of the wage-earning class. The philanthropists, and all those who now glibly repeat the formula that 'a better distribution' of the annual income of England is urgently needed, must accordingly, so far as political economy is concerned, hasten to support an Eight Hours Bill.

The important economic consequence which is likely really to follow a gradual and partial shortening of the hours of labour is a steady and permanent rise in the labourers' standard of comfort. An absolute refusal to legislate on the point would threaten far more dangerous results. Such great disputes as those of the coal-miners in I 893, and the engineers in 1897, produce ten times more industrial dislocation and loss of foreign trade than any reasonable legislation. 11 The rapid growth of feeling in the northern industrial centres, together with the profound discontent of the London workmen, are making further concessions to 'Labour' inevitable. Parliamentary candidates all over the country are bowing their necks unwillingly to the new yoke, and pledging themselves, with more or less mental reservation, to support an Eight Hours Bill. The great mass of the newly enfranchised 'Labour vote' is still suspicious of the two great political parties, and absolutely unresponsive to the ordinary party cries. The shortening of the hours of labour lies nearest to the heart of every urban labourer, and is rapidly being pushed to the front as his first demand from the legislature. Hitherto he has scarcely recognised his new power ; former 'Labour leaders' have often been wedded to narrow and purely political ideals: and the workman has accepted his politics ready 
made. But new portents are visible in the electoral sky, and students of political meteorology among the industrial classes already begin to declare that the party which first takes up the Eight Hours Bill, besides effecting an unparalleled improvement in the social condition of the worker, will gain the urban Labour vote for half a generation. $^{1}$

1 A convenient summary of facts and arguments, with many references to British or foreign literature on the subject, will be found in the Eight Hours Day (London, 189I), by Sidney Webb and Harold Cox. The history of the movement is more precisely given in the History of Trade Unionism (London, 1894), and the economic position is more elaborately analysed in Industrial Democracy (London, 1898), which gives the references to the latest authorities. 


\section{CHAPTER VI}

\section{HOW TO DO AWAY WITH THE SWEATING SYSTEM ${ }^{1}$}

BEFORE we can hope to solve the problem which forms the subject matter of this paper, we must answer two preliminary questions. First, we must decide what we mean by sweating and the sweating system; and secondly, we must determine what are the causes of these evils. For it is obvious that without an exact conception of the nature of the suffering which we desire to remedy, without some idea of the sources of the evils which we are determined to cure, we shall fail to grapple with the practical question of 'How to do away with the Sweating System.'

Fortunately for us the first question has already been adequately answered by an august authority. Almost the only result of the elaborate inquiry into the sweating system, ${ }^{2}$ conducted by a Committee of the House of Lords in I 888-90, was an accurate definition of sweating at once comprehensive and concise. Lord Derby and his colleagues finally decided that sweating was no particular method of remuneration, no peculiar form of industrial organisation, but certain conditions of employment-viz. unusually low

1 A paper read at the twenty-fourth annual congress of Co-operative Societies, held at Rochdale, June 1892 .

2 The voluminous Report and Evidence of this committee is published as a parliamentary paper, H.L. 62 of 1890 . An article by the present writer in the Nineteenth Century for May 1890, entitled 'The Lords and the Sweating System,' gives a critical analysis of the recommendations. A useful summary of the evidence is published by the Women's Liberal Federation, price Id. A systematic analysis of the whole problem is concisely given in Fabian Tract, No. 50, Sweating, its Cause and Remedy. 


\section{40 How to do away with the Sweating System}

rates of wages, excessive hours of labour, and insanitary work places. When we get any one of these conditions in an extreme and exaggerated form-for instance, when we find a woman sewing neckties in her own home, straining every nerve to earn only a halfpenny an hour-still more, when we see all these conditions combined, as in the cellar $\mathrm{dwellings}$ in which the Jewish boot-finishers work sixteen or seventeen hours a day for a wage of I 2 s. per week-then we say that the labour is sweated, and that the unfortunates are working under the sweating system.

Let us, therefore, pass on to the second point. What are the causes that produce these evils? Some persons maintain that sweating is restricted to industries in which sub-contract prevails; that, in fact, it is the middleman who is the sweater; that this man grinds the face of the poor, and takes from them the fruits of their labour. You will remember a cartoon that appeared in Punch about the time of the House of Lords' inquiry, in which the middleman was represented as a bloated man-spider sucking the life-blood out of men and women who were working around him. Now, before I studied the facts of East London industries for myself I really believed that this horrible creature existed. But I soon found out that either he was purely a myth, or that the times had been too hard for him, and that he had been squeezed out of existence by some bigger monster. For I discovered that in the coat trade, and in the low-class boot trade-which are exclusively in the hands of the Jews-where the work is still taken out by small contractors, these middlemen, far from being bloated idlers, work as hard, if not harder, than their sweated hands, and frequently earn less than the machinist or presser to whom they pay wages. On the other hand, in those trades in which English women are employed-such as the manufacture of shirts, ties, umbrellas, juvenile suits, etc. - the middleman is fast disappearing. It is true that formerly the much-abused sub-contract system prevailed in these trades-that is to say, some man or woman would contract 
with the wholesale manufacturer to make and deliver so many dozen garments for a certain sum. He would then distribute these garments one by one in the homes of the women, or perhaps he would engage women to make them in his own house. He might receive a shilling for the making of each garment, but he would give only tenpence to the actual workers, pocketing twopence in return for his trouble and risk. But of late years the more enterprising wholesale manufacturers, have thought it most unjust that the middleman should pocket the twopence. To remedy this injustice they have opened shops all over the East End of London, where they give out work just as the middleman used to do, first to be machined and then to be finished. But, strangely enough, they still pay tenpence to their workers, the only difference being that instead of the middleman getting the balance they pocket the twopence themselves. Nor do they trouble themselves in the very least where these garments are made. The women who support themselves and perhaps their families by this class of work live in cellars or in garrets, sometimes two or three families in one room. This does not concern the wholesale manufacturer. No doubt he would tell you that the middleman was the sweater and that he had destroyed him. But, unfortunately, he did not destroy, or even diminish, what the practical observer means by sweating. The actual worker gains absolutely nothing by the disappearance of the subcontractor, middleman, or so-called sweater. In East London the change has been, so far as the workers are concerned, from out of the frying-pan into the fire.

And if we leave the clothing trade, and pass to the lower grades of the furniture trades, in which all the evils of sweating exist, we may watch the poverty-stricken maker of tables and chairs hawking his wares along the Curtain Road, selling direct to the export merchant, or to the retail tradesman - or perchance, to the private customer. In the manufacture of cheap boots in London, of common cutlery at Sheffield, of indifferent nails at Halesowen, we meet with 


\section{How to do away with the Sweating System}

this same sorrowful figure - the small master or out-worker buying his material on credit, and selling his product to meet the necessities of the hour; in all instances underselling his competitors, great and small. Respectable employers, interested in a high standard of production, trade unionists, keen for a high standard of wage, agree in attributing to this pitiful personage the worst evils of the sweating system. Here, not only do we fail to discover the existence of sub-contract, but even the element of contract itself disappears, and the elaborate organisation of modern industry is replaced by a near approach to that primitive higgling of the market between the actual producer of an article and the actual consumer-to that primæval struggle and trial of endurance in which the weakest and most necessitous invariably suffers.

I do not wish you to imagine that I deny the existence of the sweater in the sweated industries. But I deny that the sweater is necessarily or even usually the sub-contractor or employing middleman. The sweater is, in fact, the whole nation. The mass of struggling men and women whose sufferings have lately been laid bare are oppressed and defrauded in every relation of life : by the man who sells or gives out the material on which they labour; by the shopkeeper who sells them provisions on credit, or forces them under the truck system; by the landlord who exacts, in return for the four walls of a bedroom, or for the unpaved and undrained back-yard, the double rent of workshop and dwelling ; and, lastly, by every man, woman, and child who consumes the product of their labour. In the front rank of this, the most numerous class of sweaters, we find the oppressed workers themselves. The middleman where he exists is not the oppressor, but merely one of the instruments of oppression. And we cannot agree with Punch's representation of him as a spider devouring healthy flies. If we must describe him as a noxious insect we should picture him much more truly as the maggot that appears in meat after decay has set in. He is not the cause, but one 
of the occasional results of the evil. He takes advantage of the disorganised state of the substance which surrounds him, and lives on it; if he does not do so, some other creature will devour both him and his food. What we have to discover, therefore, is the origin of the disorganisation itself. ${ }^{1}$

Now, in all the manufacturing industries in which 'sweating' extensively prevails we discover one common feature. The great mass of the production is carried on, not in large factories, but either by small masters in hidden workshops, or by workers in their own dwellings. And, as a natural consequence of this significant fact, the employer - whether he be the profit-making middleman, wholesale trader, or even the consumer himself-is relieved from all responsibility for the conditions under which the work is done. The workers, on the other hand, incapacitated for combination by the isolation of their lives, excluded by special clauses for the protection of the Factory Acts, are delivered over body and soul to the spirit of unrestrained competition, arising from the ever-increasing demand for cheap articles in the great markets of the world. If we compare this state of things with the industries in which sweating does not exist, we see at once that in the case of the engineer, the cotton-spinner, or the miner, the men work

1 The common assumption that sweating arises principally from the struggle for existence among destitute aliens appears to me to be inaccurate. No one would deny that the evils of sweating are aggravated by the presence of workers such as the Jews, with an indefinitely low standard of life and an absence of skill. (See the preceding chapter, 'The Jews of East London.') But all the evils of sweating exist where neither Jews nor foreigners have yet. penetrated (as, for instance, in the chain and nail industry); or where their competition is but little felt (as in the low-grade furniture trade). Even in the clothing trades the competition of Jewish immigrants is practically limited to some branches of the tailoring and boot and shoe trades. On the other hand, we are everywhere confronted with a large supply of cheap female labour, far exceeding in numbers even the most exaggerated estimate of alien immigration. The evil effect of Jewish immigrants on the labour market is, indeed, not a question of fact, but a question of proportion. The Jews are counted by their thousands; the women, dragging in their real semi-dependent husbands and a huge force of unprotected children, may be numbered by hundreds of thousands. This aspect of the subject is discussed in various chapters in Mr. Charles Booth's Life and Labour of the People; and in Industrial Democracy, part ii. chap. x. sec. 4, 'The Ex. clusion of Women.' 


\section{I44 How to do away with the Sweating System}

together in large establishments, and the employer becomes responsible for the conditions of their employment. The mill-owner, coal-owner, or large iron-master, is forced to assume, to some slight extent, the guardianship of his workers. He is compelled by the State to provide healthy accommodation, to regulate the hours of labour of women and young persons, to see to the education of children, to guard against and insure all workers against accident. Trade unions, arising from the massing of men under the factory system, insist on a recognised rate of wages. Public opinion, whether social or political, observes the actions of a responsible employer in the open light of day. Willingly or unwillingly, he must interpose his brains and his capital between groups of workers on the one hand, and the great mass of conscienceless consumers on the other. These are the services exacted from him by the community in return for the profits he makes. $\mathrm{He}$ is, in fact, the first link between the private individual intent on his own gain, and the ideal official of the Socialistic State administering the instruments of production in trust for the people. It is the absence of this typical figure of nineteenth-century industry which is the distinguishing feature of the sweating system.

On the other hand, we have seen, in the sweated industries, how, by the system of home-work, the virtual employer altogether escapes the responsibilities of his position. He gives out his work from an office to a miscellaneous and scattered set of workpeople, whose places of abode he scarcely even knows; his work is done in uninspected domestic workshops, it may be under the most insanitary conditions ; his employees must, as he knows, often toil far into the night to comply with his demands, but he incurs no penalty. Alike from the obligations and the expenses of the factory owner, the sweater is free. Meanwhile, the slum landlord is receiving, for his cellars and attics, the double rent of workshop and dwelling without incurring the expensive sanitary obligations of the mill-owner. In short, it is 
home work which creates all the difficulties of our problem. For it is home work which, with its isolation, renders trade combination ${ }^{1}$ impracticable ; which enables the manufacturer to use as a potent instrument, for the degradation of all, the necessity of the widow or the creed of the Jew. And more important still, it is home work which, by withdrawing the workers from the beneficent protection of the Factory Acts, destroys all legal responsibility on the part of the employer and the landlord for the conditions of employment.

Clearly we must first see to it that our own house is in order. I am glad to think that co-operators as employers already recognise their duty as regards the payment of fair wages, the exaction of reasonable hours of labour, and the provision of sanitary workplaces for all their employees. This special responsibility of co-operators as employers has often been dwelt upon. The shirt-making shops of the Scottish Co-operative Wholesale Society at Shieldhall offer a brilliant example of what may be done by co-operative enterprise in an industry usually abandoned to the sweater. ${ }^{2}$

But it is useless to shut our eyes to the fact that cooperators can never hope to become the employers of the great mass of the workers who suffer under the sweating system. Taken as a whole the sweated industries may be said to work mainly for export. The low-class clothing made in East London is largely worn, not by our own people, but by the inhabitants of Australia and the Cape. The

1 I have not attempted in this paper to deal with home work from the standpoint of trade unionism; but if systematic home work be unfavourable to the growth of co-operation, it is absolutely fatal to the stability, or perhaps even to the existence, of trade combination. Trade unionists are, of all reformers, the most vitally interested in the abolition of workplaces withdrawn from the jurisdiction of law, trade-union regulation, and public opinion. On this point see Industrial Democracy, vol. ii. part ii. chap. xii.

2 The movement against sweating would be assisted if co-operators invariably insisted that no order should be given to any but 'fair' houses innocent of sweating. Every town council or other public authority should be urged to follow the example of the London County Council, in insisting on the payment by all contractors of the standard rate of wages in each occupation, and in rigidly refusing all tenders from 'unfair' firms. The cheapness of the sweater (often, by the way, delusive) is the price of blood. 


\section{I46 How to do away with the Sweating System}

common boots and shoes turned out wholesale by the Jewish families of Whitechapel, or the Leicestershire villagers, equally supply the Colonial market. The sweated knives of Sheffield disgrace her name and injure her commercial prestige throughout the whole world. Even the most patient Conservative would not ask us patiently to watch the degradation of large sections of our countrymen whilst the Co-operative Wholesale Society is enroling, as members, the dusky Indian or the almond-eyed Mongolian, who are to so large an extent the virtual employers of the sweated workers. And even in those cases where the cheap and nasty products of the sweating system are used at home, they supply the needs neither of co-operators nor of those among whom co-operation is ever likely to flourish. The evil influence of the export sweating trade extends to that which supplies a nearer market. It is the woman earning a halfpenny an hour at clothes for the Cape who buys the cheap furniture hawked about the Curtain Road. It is the Jewish boot-finisher working for abroad who, in his turn, buys the slop clothing displayed in the sweater's front shop. We are thus in a vicious circle, where sweating itself creates the conditions for the sweating system., For can we expect the nail-maker, tolling sixteen or seventeen hours a day for bare subsistence, or the children brought up in the one-roomed homes of East or South London, to develop that high level of moral and intellectual character which experience has proved to be absolutely essential to any considerable growth of co-operative association? As a matter of fact, the officials of the co-operative movement have met with as great obstacles to the spread of co-operation among the victims of the sweating system as an ardent co-operator would experience

1 The industrial demoralisation of East London is, I believe, caused mainly by the two factors of home work and intermittent dock labour, and even the existence of so large a class of irregularly-employed dock labourers is, to a large extent, rendered possible only by the home work done by their wives. I doubt if co-operation can ever flourish in East London until these continuing sources of degradation are removed. See Industrial Democracy, part iii. chap. iii. sec. \&, 'Parasitic Trades.' 
if he insisted on going as a co-operative missionary to the South Sea Islanders.

And if it be impracticable to transform the sweater's victim into a co-operative consumer, still more impossible will it be to change him into a co-operative producer. We may differ as to the desirability of Associations of Producers in other departments of industry. But it will be needless to remind the experienced co-operator that the idea of the East End female necktie-makers, the Staffordshire nail-makers, or the Jewish boot-finishers ever being able to set up in business for themselves as associations of producers is simply chimerical. Whether or not the self-governing workshop be the goal of industrial organisation, it is certainly not the starting-point. Indeed, those who believe most firmly in associations of producers insist most keenly that it requires for its success an exceptional amount of character and intelligence on the part of the workers. Moreover, the self-governing workshop, pledged to a high standard of wage, would be subject, in the sweated industries, to the competition of the home-work system, with its degraded labour and cheap products. Should we desire, therefore, the rapid spread of co-operative production, carried on by associations of producers, our first step must be to root up and destroy the evils of sweating.

Are co-operators, then, powerless to do away with the sweating system? We must, I fear, admit that neither as employers nor as associated workers can they deal directly with the evil outside their ranks. Yet co-operators, of both schools, are most vitally interested in maintaining throughout the whole community a high standard of industrial morality. For not only does the sweating system practically exclude from their membership whole sections of . their fellow-workers, but even in their own market they are unfortunately only too liable to be attacked by unscrupulous private competitors. The failures of promising experiments in co-operative production have too often been attributed to the difficulty of obtaining a market for wellmade goods. Nearly every quarterly meeting bears 


\section{I48 How to do away with the Sweating System}

unconscious witness to the insidious influence of the lowpriced manufacturer of low-class goods, in the complaint that the Co-operative Wholesale Society or the retail store is charging, for some articles, more than the private trader. And in all the labour troubles which perplex the co-operative committee-man, it is the ever present fear of the competing sweater which at times prevents our ready acquiescence in that generous treatment of co-operative employees advocated by our most enlightened administrators.

Now, to find an effective remedy for the evils which we have been describing, we need only observe the teachings of history. When unscrupulous tradesmen ran the stores hard by subtle adulterations, co-operators became eager advocates of an Adulteration Act. When sharp competitors were passing off as English-made, low-class foreign wares, the Merchandise Marks Act was passed for the protection of more honest British traders. And if we leave for the moment the narrower aspect of the sweating system as hostile to co-operation, and consider it as involving the degradation of millions of our fellow-workers, we may again learn from history the most practical way of rendering the worst forms of sweating impossible. Seventy years ago the Rochdale weaver was, in his own way, suffering from all the evils which we now call sweating. Hours of labour stretched to the very limit of human endurance, dangerous and unventilated work-places, wages diminished by fines and fraud and truck on every side, were the hideous characteristics of Lancashire's white slavery at the beginning of this century. It is no mere coincidence that the stable growth of the co-operative movement itself was delayed until excessive toil and insanitary conditions of labour had by the Factory Acts been effectively penalised in the textile industries. Legislation, and legislation alone, was competent to cope with these gigantic evils. Similar evils elsewhere now demand similar remedies. The only radical cure of the sweating system is the application of legislative regulation to the special circumstances of the sweated industries. 
Now I venture to maintain that it is perfectly feasible to insist on the responsibility of landlord and employer in the sweated industries, and thus to bring the workers under the protection of the Factory Acts. The problem confronting us is the substitution of the factory system, with its regulated hours and enforced sanitation, for manufacturing carried on in dwellings and unregistered workshops. We cannot at one blow prohibit home work, but we must at any rate remove the exceptional legal privileges which at present offer a direct encouragement to the wholesale trader, who gives work out, to the detriment of the responsible manufacturer. ${ }^{1}$ Our task, in short, is to build up in these disorganised industries, the legal responsibility of the employer and landlord.

Without entering into the technical details of legislation which I have elsewhere proposed, ${ }^{2}$ it may broadly be said to provide for a double registration by landlord and employer of all places in which manufacturing work is carried on. The landlord, should he permit the use of his premises for manufacturing purposes, will under this proposed legislation be compelled to provide all accommodation necessary for the health of the workers. And the duty of preventing overcrowding, or any other improper use of his premises, will be as rigidly enforced on the owner of the nail-maker's hovel or the boot-finisher's cellar, as it already is on the mill-owner and the colliery proprietor. On the other hand,' the employer who, to escape the Factory Acts,

1 At present any proposal to secure better conditions for factory workers is apt to be met by the objection that it will tend to drive the work into the homes, and so perpetuate the sweating system.

2 Many of these proposals were thrown into technical form in Mr. Sydney Buxton's excellent bill for the amendment of the Factory Acts (No. 61 of 1891). I have reprinted some of the clauses as an appendix to this paper. Unfortunately, hardly any of Mr. Buxton's proposals have been carried into law, and the new Factory Act ( 54 \& 55 Vict. c. 75), whilst conceding all the demands of the well-organised cotton operatives, leaves the condition of the sweated workers, for want of the help of such a widespread organisation as the co-operative movement, even worse than before. Since this was written yet another Factory Act has been passed ( $5^{8} \& 59$ Vict. c. 37 ), which again does nothing effectual to put down sweating. See chap. iii. 'Women and the Factory Acts.' 


\section{50 How to do away with the Sweating System}

gives work out to be done at home, will be made equally responsible with the mill-owner for the age, health, education, and the hours of labour of those members of the protected classes whom he employs. ${ }^{1}$ This double responsibility of the landlord and the employer would be, I believe, a direct and fatal blow to the sweating system. Tenement landlords would hesitate to permit the use of their single rooms for manufacturing purposes if they became liable to heavy penalties for overcrowding and bad sanitation. Wholesale traders would find it more economical to erect factories than to institute an army of private inspectors to protect themselves from breaches of the Factory Act in thousands of unknown homes. Once deprive the giver-out of work of his exceptional legal privileges and there will be a steady tendency to replace the sweaters' dens by the large and healthy factories, easily controlled both by law and by public opinion, in which the great industries of the nation are already carried on. In this way, and in this way alone, can be transformed the unfortunate victims of the sweating system into such prosperous and independent operatives as now swarm the streets of Rochdale.

And while the conditions of the worker would be enormously improved, there is no reason to suppose that the cost of commodities would be increased. Already the superior quality of factory labour, with its use of machinery, renders it more than doubtful whether there is any real economy even to the employer in home work. Home work is resorted to (according to the evidence of the employer) on account of the excessive competition between traders for quick delivery of contracts. Through giving his work out

1 A necessary preliminary to the enforcement of this responsibility would be the compulsory registration, by any employer of home workers, of the names and addresses of all persons to whom he gives out work. The Lords' committee, following the precedent of a Factory Act of Victoria, recommended the enact. ment of a clause to this effect. This was embodied in the Factory Act of 1891 (sec. 27 of 54 \& 55 Vict. c. 75), and it is the only one of the committee's recommendations which has been carried into law. See The Laiv Relating to Factories and Workshops, by May Abraham and Llewellyn Davies (London, 1896.) 
to homes the employer is free, every now and then, to insist that his unfortunate slaves shall toil through the night to complete his task. Should this privilege be withdrawn from all manufacturers alike the demand of the export trader or the order of the private customer would speedily adapt itself to a more regulated supply. On the other hand, if we regard the quality as well as the price of the article, there is an almost unanimous testimony that systematic home work tends to fraudulent production. In short, it is difficult to determine whether it is the worker or the customer who is really most injured by the sweating system.

The task, therefore, which I propose for co-operators, if they really wish to do away with the sweating system, is to follow the precedents of their own action with regard to the Adulteration Acts, and the Merchandise Marks Acts, and to insist upon Parliament passing such a new Factory Act as I have been describing. They have, as we have seen, a direct interest as co-operators, both in the prohibition of demoralising forms of competition, and in the elevation of the lapsed masses now virtually excluded from their ranks. It is their chosen mission to raise the moral standard of industrial life, not only among themselves, but throughout the whole community. They possess, on such questions, an almost unlimited power, would they but choose to exercise it. The first step to reform lies through the House of Commons. We want an extension of the Factory Acts to the sweated industries. But this is a matter in which neither Liberals nor Conservatives are really interested. The miserable workers under the sweating system have no organisation through which they can compel the attention of politicians. But now that their sufferings have been made known to us, it is our duty as citizens to insist, in season and out of season, that those who ask for our votes shall have them only on condition that they will carry out our wishes in this respect. If the million co-operators had been really in earnest during I $89 \mathrm{I}$ about doing away with the sweating system, the Government would not have ventured basely to 


\section{52 How to do away with the Sweating System}

give way to the capitalist and the sweater, and to refuse all amendments of the law which would have put down the present evils. $^{1}$ If the Lancashire cotton operatives had been as eager to put down sweating as they were to make their own desires with regard to improvement of the conditions of labour in cotton factories into law, both front benches would have done their bidding in the one matter as they did in the other.

Next year the question will come up again, perhaps under a new government. What action will co-operators take? It rests with you to decide whether your parliamentary committee shall take it up in earnest, whether you will press it upon every candidate whom you can influence, whether from store meeting and district conference this autumn, up and down the land, there shall descend upon M.P.'s, Liberal and Conservative alike, such a flood of resolutions demanding legislation against sweating as shall convince them that the time has gone by for any more shuffling, and that the whole co-operative movement has made up its mind that this dire iniquity shall cease out of the land. These are the practical steps by which, as it seems to me, co-operators can 'best do away with the sweating system.'

\section{APPENDIX}

The following clauses are reprinted from Mr. Sydney Buxton's bill (No. 6I of $189 \mathrm{I}$ ), as the best proposals on the subject yet put into parliamentary form. They represent, however, the minimum of responsibility that should be enforced. The responsibility of the giver-out of work for the hours of labour of the protected. classes should also be insisted on in future legislation.

\section{LANDLORD'S RESPONSIBILITY FOR SANITATION}

The person responsible as owner, under the Acts relating to the public health, for the sanitary condition of any premises used as a factory or

1 It is sometimes said that to seek new legislation is beyond the sphere of co-operators. But the great political influence of the co-operative movement is constantly being exerted in order to secure new legislation. Among bills lately promoted or supported by the organised strength of co-operators may be named the Food and Drugs Act, the Leaseholds Enfranchisement Bill, measures relating to property qualification for public office, etc. etc. 
workshop, shall be also responsible, concurrently with the occupier, for compliance with such of the requirements of the Factory and Workshops Acts as relate to the sanitary condition of the said premises; and it shall be within the discretion of the factory inspector to proceed against either owner or occupier for the purpose of enforcing the said requirements.

When it shall appear to a Secretary of State, upon the report of any factory inspector, that any factory, workshop, or domestic workshop, is in such a condition as seriously to impair the health of the persons employed therein, and that the owner or occupier thereof, within the space of one month after notice thereof has been given to him, has failed to remedy the defects, the Secretary of State shall have power, by order issued in the manner prescribed by section 65 of the principal Act, and also served upon the said owner or occupier, to require the premises to be forthwith closed, and to remain closed until they have been brought into conformity with the principal Act and the Acts amending the same.

Any person letting for hire premises for the purpose of being used as a domestic workshop, or having reasonable grounds for believing that they are so used or intended to be so used, shall serve notice in writing upon an inspector, specifying the name, if any, and exact address of such premises, the name and address of the occupier thereof, and the name and address of the person responsible as owner of the said premises in accordance with the Public Health Acts, and the inspector shall, on receipt of such notice, forthwith inspect the said premises, and register the same free of charge.

In the event of contravention of this section, the person aforesaid shall be liable to a fine not exceeding five pounds.

The provisions of this section shall only apply to such districts as may be from time to time specified by a Secretary of State by order issued in pursuance of section 65 of the principal Act.

The person responsible as owner under the Public Health Acts shall be required to ensure that any premises let for hire by him for the purpose of being used as a factory, workshop, or domestic workshop, or which he might reasonably suppose to be hired for the purpose of being so used, are in a proper sanitary condition for the purpose; and he shall be deemed, any agreement to the contrary notwithstanding, to warrant the premises as so fit.

In the event of a contravention of this section, the owner of the said premises shall be liable to a fine not exceeding five pounds.

\section{RESPONSIBILITY OF THE EMPLOYER}

It shall be the duty of the occupier of any premises (whether a factory, workshop, domestic workshop, or otherwise) who, in connection therewith, or for the purposes of the occupation carried on there, gives 


\section{54 How to do away with the Sweating System}

out any material or other article to be manufactured or worked upon by manual labour as defined by section 93 of the principal Act, at any other place than in the said premises in his occupation, to keep a register of the name and address of each person to whom such material or other article is given out, and the date of such delivery, and such register shall be open to inspection by any such person, or the secretary of any trade society, and any inspector and by any officer of the sanitary authority who shall have power to copy any part thereof.

In the event of a contravention of this section in regard to the registering, the occupier of the premises from which such work is given out shall be liable to a fine not exceeding five pounds.

In the event of work being given out to any person who is not on the register, the occupier of the premises from which the said work is given out shall be liable to a fine of not less than ten shillings or more than three pounds.

The occupier of any premises who habitually gives out material or other articles to be manufactured or worked upon by manual labour, as defined by section 93 of the principal Act, at any other place than the said premises, shall be held responsible for the observance of the sanitary provisions of the principal Act, and of any Acts amending the same, with regard to the domestic or other workshops in which such labour is performed, and shall, concurrently with the occupier thereof, be liable to any penalties incurred for any failure to keep the said domestic or other workshops in conformity with the Act.

In construing this section any person to whom the material or other article belongs, which is found upon any premises not kept in conformity with the Act, shall, concurrently with the occupier thereof, be deemed to be liable in the same manner as if he were the occupier thereof.

If an inspector finds any premises in which any manual work, within the meaning of this Act, is being done, to be in an insanitary condition, he shall, if he deems it necessary, thereupon give notice thereof to all persons whose materials or other articles he finds on the said premises, and to any other person known to be in the habit of giving out such materials or other articles to the occupier of the said premises, and if, after a period of three weeks, the premises have not been put into proper sanitary condition, no such person shall continue to give out work to the said occupier under penalty of a fine not exceeding five pounds.

If an inspector discovers on any premises, or portion of the premises, in which any manual work, within the meaning of this Act, is being done, any person residing therein to be suffering from a contagious disease, he shall, if he deems it necessary, give notice thereof to all persons whose materials or other articles he finds on the said premises, or to any other person known to be in the habit of giving out such materials or other articles to the occupier of the said premises, that no 


\section{How to do away with the Sweating System 155}

such person shall give out any further materials or other articles afore said to the occupier of the said premises until the persons residing therein are free from contagion.

Any person giving out materials or other articles as aforesaid to the occupier of a domestic or other workshop, in contravention of this section, shall be liable to a fine not exceeding twenty pounds. 


\section{CHAPTER VII}

THE REFORM OF THE POOR LAW ${ }^{\text {! }}$

FEW persons appear adequately to realise the pólitical instability of the existing system of Poor Law Relief. Its present administration is a nicely balanced mean between the indiscriminate generosity of the Old Poor Law and the scientific rigour intended by the more extreme advocates of the New. The present equilibrium, by which the total amount of pauperism is, at any rate, kept from increase, is the result of the almost innumerable experiments of the great measure which Lord Althorp in 1834 triumphantly piloted through a bewildered House of Commons. ${ }^{2}$ That measure, carried by the Whig respect for the metaphysical economists of the time, and by the argumentative power of the great Report of 1834 , has never received the support, or even the assent, of the great mass of the wage-earning class, now for the first time becoming effectually enfranchised. It did more than anything else to promote the growth of militant Chartism. For fifteen years after its enactment the popular clamour never ceased against the iron bonds in which the Reformed Parliament had encased the nation's collective provision for the destitute and the infirm. Then came, leaping and bounding, the time of relative prosperity and political subsidence of the English proletariat, and a new generation grew up, to whom the Old Poor Law, like the enclosed commons and the lapsed charities, was but a vague tradition of extinguished public rights. But such

1 Contemporary Review, July 1890.

8 Only twenty members voted against the Second Reading 
traditions linger long and bitterly; and the agricultural labourer, in particular, still sullenly resents his dependence on the good pleasure of an absentee board, composed of his masters, for the weekly dole of outdoor relief which forms his almost inevitable portion in old age. The town unskilled labourer, in his chronic condition of winter unemployment, demands with even stronger persistence that his appeal shall not be met merely by an offer of 'the house,' or of the stone-yard, and it becomes increasingly obvious that popular feeling cannot be relied upon to uphold any rigid refusal of outdoor relief even to able-bodied adults.

The possibility of a renewed popular attack on the system of Poor Relief would not be serious if reform could be left to Poor Law experts, or confined to persons who have read the great Report of 1834 . But the Poor Law expert is now somewhat discredited among democratic politicians, owing to his ignorant adherence to an obsolete political economy, and his blind refusal to recognise the general abandonment of that individualism which so long formed the ideal of middle-class Liberalism. In these days of Marshall and Sidgwick, people who still talk about the 'wage fund,' and the 'terrible' increase of population, ${ }^{1}$ are as much out of date as that dwindling remnant which still resists on principle any extension of public administration.

The average member of Parliament, on the other hand, knows nothing of Poor Law administration, and has but the vaguest idea of the Report in 1834 . He is easily led by the growing social compunction of the age to acquiesce in anything promising a more generous treatment of the poor. He will not attempt the task of a Poor Law Amendment Bill, but he may probably vote in Committee on the next

1 See Industrial Democracy, part iii. chap. i. 'The Verdict of the Economists.' It is interesting to notice that, as far back as 1587 , all the evils of the day were ascribed to the 'too great store of people in England, and that youth, by marrieng too soone doo nothing profit the countrie, but fill it full of beggars, to the hurt and utter undooing (they saie) of the commonwealth.' See William Harrison's ' A Description of England' in Holinshed's 'Chronicles,' p. xxxiv. of Mr. Furnivall's preface to Elizabethan Englana'. 
Local Government Bill for an amendment giving Parish Councils discretionary power to grant outdoor relief, or some other proposal equally likely to land us once more in the demoralising horrors of the Old Poor Law.

Even the Poor Law experts do not agree in defence of the existing system of Poor Law administration. There is indeed a widespread feeling among them - a feeling which will be shown to be entirely justified-that a sweeping reform is required.

The fact is that the New Poor Law has by this time worked itself out. The main evils against which it was directed have now virtually disappeared. The chief objects of the Commissioners have been attained. No one acquainted with English history or Poor Law work will, for an instant, depreciate the enormous reform effected by the Act of 1834. No one can doubt the good which the bracing system initiated by that Act has done in the way of educating the people in the intelligent and self-respecting ordering of their own lives. But the work has so far succeeded that the evils to be encountered to-day are not those with which the reformers of I 834 had to deal. Standing on their shoulders we have to-day a different task from theirs. In that creation of individual character, which is the real goal of all collective effort, the time has come for a new departure.

The Poor Law Commissioners of I 834 found a system of Poor Law relief which virtually made every labourer a pensioner of the landowner, without either the labourer or his employer being in any way pecuniarily benefited by the subsidy. Of the serious demoralisation which this was causing it is unnecessary now to speak. The 'allowance system' and the 'labour rate' are probably responsible, jointly with the 'white slavery' inaugurated by the great industrial revolution, for most of the degeneration of character of that 'residuum' whose condition even that optimistic statistician Sir. R. Giffen declares to be 'a stain on our civilisation.' ${ }^{1}$ The New Poor Law aimed specially

1 Essays in Finance, vol. ii. p. 350 . 
at abolishing outdoor relief to the able-bodied, and it has, after sixty years' patient effort by thousands of Poor Law workers, practically succeeded in accomplishing this great task. The adult male paupers in receipt of outdoor relief, who are classified as 'able-bodied' in the Returns for the Ist of January I 897, numbered, in all England and Wales, only I 3,910 , and of these 9356 were relieved on 'account of their own sickness, accident, or infirmity.' Only 789 were relieved 'on account of want of work, or other causes,' and I 3 I 'on account of sudden and urgent necessity.' ${ }^{2}$ The abolition of outdoor relief to able-bodied male adults is virtually complete: The able-bodied women, in receipt of outdoor relief are more numerous, but still number less than 55,000 in England and Wales, two-thirds of these being widows with young children.

Other recommendations of the Commissioners have been equally successful. The central Poor Law authority has been of enormous use in securing a uniform administration of the law. The educational and charitable endowments have been to a large extent reformed. The hideous old law of bastardy has been amended. The absurd litigation as to settlement has been practically stopped. Probably no State Paper has ever had so great a result, or has so uniformly secured the assent, so far as regards the particular issues dealt with, of those competent to weigh the points at issue.

The New Poor Law has, however, failed to extinguish pauperism and destitution. It succeeds in obviating any but a few cases of direct starvation, but it does not prevent a widespread demoralisation of the pauper class. It often fails to rescue the children from a life of pauperism, and the aged from public disgrace. More important than all, it fails utterly in its chief and most important purpose, of encouraging the thrifty and the worthy, and discouraging the spendthrift and the drunkard. It is, indeed, now coming to be denounced by experienced philanthropists as the greatest of all the existing hindrances to English thrift and

1 Annual Report of the Local Government Board I896-7, C. -8583 of 1897. 
providence, and an instrument of serious degeneration of character among the English poor. ${ }^{1}$

One school of Poor Law Reformers, strong on Charity Organisation Society Committees, but scarcely represented at all on the hustings, aims at the ultimate abolition of all public provision for destitution. Its members either believe, with Cobden and W. J. Fox, that individual prosperity can be so universally diffused that our workhouses will fall into ruin, or else they look forward to a return of the mediæval millennium in which all almsgiving was left to the voluntary goodwill of the individual citizen, spurred on only by the teachings of the Church.

Here all democratic reformers at once part company with those workers who aim at nothing short of the total abolition of the Poor Law and the Poor Rate. The complete abolition of poverty and want is absolutely impossible (until we reach Communism itself) in a land of accident and sickness. The substitution of private philanthropy for the public provision for our poor citizens (already emphatically condemned by Bentham), is decisively negatived by modern Radicalism. The Eleusis Club Report of I 889-a remarkable document published by the well-known working men's club at Chelsea-is very clear on this point :-

We believe that all poor relief should be administered under the fullest public responsibility by freely elected public bodies. We therefore believe that any attempt to substitute the organisation of voluntary charity for public relief would prove disastrous because :-

(a) The history of hospital and church charities shows that any such voluntary method, however carefully guarded in the beginning, is more likely to result in waste and jobbery than a system of public control.

(b) The fact of relief depending on the voluntary gifts of the wealthy, encourages the notion that the industrious poor owe the means of livelihood to the existence of a rich and idle class.

1 See Thrift and Independence, by Canon Blackley; Mackay's The English Poor; the Charity Organisation Society's publications, passim; Fawcett's Pauperism; Dispauperisation, by J. R. Pretyman; The Better Administration of the Poor Law, by W. Chance; and the evidence given before the Select Committee on National Provident Insurance, H.C. -270 of 1885 . 
(c) All the evils, such as improvidence and idleness, which may be produced by public relief, are intensified in the case of private charity.

Moreover, it must not be forgotten that no scheme which aims at the abolition or diminution of the present revenue from Poor Rates can gain the support either of the public or of the political economist. These twelve millions sterling, virtually a share of the rental of the country, are, as Professor Marshall says, as much the property of the poor as their wages, and no proposal can be for a moment admitted which contemplates the absorption of this tribute by the landlords or the middle class. National insurance or Poor Law Reform can alike be but suggestions for the better administration of the collective revenues of the poor - the modern substitute for the monastic endowments, the mediæval charities and the common lands.

Those who talk glibly about the abolition of the Poor Law can hardly have any correct idea of the extent and character of the pauper class to-day. It seems to have been assumed by the authors of the Act of $i 834$ that real destitution might fairly be regarded as an exceptional and accidental state, and that the awful permanence of the pauper class was merely the result of the demoralising old system. Pauperism, as we are often told in Poor Law Conferences to-day, is a 'disease,' produced by injudicious administration; the implication being that it can be 'stamped out' by a due .course of 'resolute government.' This idea constantly recurs in Harriet Martineau's Tales, which did so much to spread the principles of the New Poor Law. It is encouraged by the optimistic statistics reiterated by the Local Government Board, which used annually to show: ' That the mean number of paupers relieved in the parochial year ending at Lady Day I 889, was smaller in proportion to the population than in any other parochial year included in the table. It amounted to 795,617, or a thirty-sixth of the estimated population.' ${ }^{1}$ This optimism had lately been

i P. 1xi. of C. $-58 \mathrm{r} 3$. 
slightly shaken by the statistician noticing that the decline of pauperism had stopped. In I 896-97 the mean number in receipt of relief had risen to $8 \mathrm{I} 4,887$. Including Scotland and Ireland, the total becomes over a million.

A million of our fellow-citizens in pauperism is scarcely a quantite négligeable, and is not a hopeful result of over sixty years of as resolute Poor Law Government as we are at all likely to get. But that is not the whole tale. It has been pointed out over and over again that the Local Government Board statistics of pauperism, and especially the references to 'one thirty-sixth of the population' are misleading. They record merely the number of persons in actual receipt of Poor Law relief on one particular day. But Poor Law relief is now usually given for short periods at a time, and a large proportion of those who become paupers during any one year are not in receipt of relief during the whole of the year. The plan of granting relief only for short periods at a time is steadily becoming general.

In 1857 , the Local Government Board did give statistics of the number of separate persons (not cases) who, during the year, were paupers at one time or another. The total was found to be $3 \frac{1}{2}$ times the number for one day, and this calculation has since usually been accepted. Hence, instead of 2.8 per cent, we get nearly Io per cent of the population, or at least $3,500,000$, as the class actually pauper during any one year. ${ }^{1}$

1 National Income, by Dudley Baxter, p. 87 ; Dictionary of Statistics, by M. G. Mulhall, p. 346. This statement, based on the best information then accessible, at last broke through the self-complacent optimism of the Local Government Board, and resulted in further inquiries being made. These inquiries, which are described in Mr. Charles Booth's Pauperism and the Endowment of Old Age (London, I 892), and the Aged Poor (London, I894), appear to indicate that the hitherto accepted multiplier of $3 \frac{1}{2}$ per cent was too high. The return presented to Parliament in June I893 gives the 'year's count' of separate persons relieved in England and Wales during I $89 \mathrm{I}-92$ as I,573,074, excluding pauper lunatics and vagrants. Taking these at 100,000 , we get a total of $1,673,074$; and adding an estimate for Scotland and Ireland, we reach an estimated aggregate total for the United Kingdom, of the class obtaining relief during any given year, of at least $2,000,000$. 
This is not the worst aspect of the case. While a man or woman is in the prime of life, and free from sickness or accident, it may be assumed that pauperism is relatively exceptional. The appalling statistics of the pauperism of the aged are carefully concealed in all official returns. No statistics are given by the Local Government Board as to the percentage of aged paupers. No information was given on this point, even in the census of $188 \mathrm{I}$. Although the occupations at each age were then obtained, the RegistrarGeneral discreetly and humorously merged all paupers over sixty in the class ' retired from business,' so that the enriched army contractor and his aged workpeople were combined to swell this one category.

In I 885 Canon Blackley found that in his parish 37 per cent of the deaths of persons over sixty, during fifteen years, had been those of paupers. He obtained returns from twenty-five other rural parishes, and found that 42.7 per cent of deaths of persons over sixty were those of paupers. ${ }^{1}$ Returns obtained by the present writer in 1890 from twenty Unions in England, selected entirely haphazard, and including metropolitan and provincial, urban and rural districts, show the following results :-

\begin{tabular}{|c|c|c|c|}
\hline Total paupers in 20 Unions. & $\begin{array}{l}\text { Indoor. } \\
12,669\end{array}$ & $\begin{array}{l}\text { Outdoor. } \\
\text { I } 5,922\end{array}$ & $\begin{array}{l}\text { Total. } \\
28,591\end{array}$ \\
\hline Number over sixty-five years of age & 4,332 & $7, \mathrm{I}$ I 2 & I I, 444 \\
\hline $\begin{array}{l}\text { Percentage } \\
\text { Number over seventy years of age }\end{array}$ & $\begin{array}{r}33 \\
2,728\end{array}$ & $\begin{array}{r}45 \\
4,728\end{array}$ & $\begin{array}{r}40 \\
7,456\end{array}$ \\
\hline Percentage. & 2 I & 30 & 26 \\
\hline
\end{tabular}

If we may assume these Unions to be fairly representative of the whole-and the results coincide closely with those given by other tests-it would follow that out of the 817,190 persons simultaneously in receipt of Poor Law relief in England and Wales, on the Ist of January I 889 , there would be 325,000 over sixty-five, and 2 I 2,000 over seventy years of age. At the census of $188 \mathrm{I}$, the percentage of 1886.

1 Report of Committee on National Provident Insurance, p. I 59 of H.C. 208. 
persons over those ages to the whole population was 4.57 and 2.64 respectively. Among the estimated population on Ist January I 889 , of $28,628,804$, there would accordingly be about $1,309,000$ persons over sixty-five. One in four of these is a pauper. There are approximately 756,000 persons over seventy. Of these two out of seven are permanent - paupers. Of the 325,000 paupers over sixty-five, about 2 I 5,000 get outdoor relief; of the 2 I 4,000 over seventy, about I 35,000 receive this weekly dole; the remainder are in the workhouse infirmary, or aimlessly gazing at vacancy in the dreary 'idle room' of the workhouse itself.

Extending these statistics roughly and hypothetically to the United Kingdom, with its million of simultaneous paupers, and its 38 millions of population, we find about $1,700,000$ persons of sixty-five years of age, of whom about 400,000 are permanent paupers; and about $1,000,000$ persons over seventy, of whom 260,000 are permanent paupers. ${ }^{1}$ Other statistics go to confirm this broad result.

In London one person in every four will die in the workhouse, hospital, or pauper lunatic asylum. In I 895 out of 85,601 deaths in London, about half being over twenty, 1 3,089 were in workhouses, 8230 in hospitals, and 357 in lunatic asylums, or altogether 21,676 in public institutions. $^{2}$ Moreover, the percentage is increasing. In

1 Here, too, further inquiries were set on foot after publication of this startling statement. The statistics thus obtained have been elaborately analysed by Mr. Charles Booth in the two works already cited. The result is to show that my estimate of old-age pauperism was actually too low. Mr. Charles Booth states (The Aged Poor, p. 420), that 'the whole number of those over sixty-five relieved in the twelve months was 401,904. Of these, II 4,144 had relief indoors, and 287,760 outdoors, including in the latter 25,477 who are returned as having medical relief only.' These definitely ascertained statistics refer only to England and Wales.

We may now put the 'year's count' of paupers over sixty-five in the United Kingdom as certainly exceeding 500,000; or more than a fourth of all the persons who have reached that age. At least 300,000 of them are over seventy years of age, being 35 per cent of all the men and women of that age.

2 Fifty-eighth Annual Report of the Registrar-General, I 895, C. -8403 of 1897. These figures are understated, as the tendency is more and more to remove public institutions of this character outside the London boundary. At least 1500 deaths took place in London workhouses, asylums, etc., beyond the limits of the county. 
1887 it was 20.6 of the total deaths; in 1888 it rose to 22.3 ; in 1895 it reached 25.2. The increase was almost exclusively in the deaths in workhouses and workhouse infirmaries. Considering that comparatively few of the deaths are those of children, it is probable that one in every three London adults will be driven into these refuges to die, and the proportion in the case of the 'manual labour class' must of course be still larger. The number of persons who die whilst in receipt of outdoor relief is not included in this calculation.

Nor is there much hope of appreciable reduction in these figures. The proportion of paupers to population has remained practically stationary for the last twenty years. ${ }^{1}$ The steady diminution in the number of able-bodied adults relieved is counter-balanced by an equally steady growth in the number of sick persons and lunatics, for whom collective provision is now made, as well as apparently by a slight rise in the number of the children and the aged. We may for some time to come reckon on having to make constant public provision for the needs of a million people in receipt of relief, representing a pauper population of at least two millions. It ${ }^{*}$ accordingly behoves us to see that this collective provision is as far as possible prevented from having demoralising or other injurious effects. The collective provision may of itself be demoralising to character and detrimental to the best interests of the recipients. But as we cannot get rid of it, we must endeavour to minimise whatever evils are inherent in the system. We need not add to the assumed objective demoralisation of the collective provision any unnecessary subjective demoralisation due to public stigma or disgrace. So far as is safe we must depauperise our paupers. The whole range of Poor Law experience up to I 834 appeared to show that public boards could not be trusted to discriminate between individual cases, and the cast-iron rigour of the New Poor Law was the inevitable result. What we have been learning since 1834 is that discrimination must be more and

1 See Local Government Board Report, C. -58 I 3 . 
more exercised between classes of paupers, not between individual cases, and that any Poor Law reform must necessarily proceed on this basis.

Now, in the classification of the permanent pauper class we cannot do better than follow the quaint categories set down by a kind of 'Mansion House Council' in I 553, which was set on foot by the 'good young King Edward VI.' when he had been moved by a sermon of Bishop Ridley's to write to the Lord Mayor, Sir Richard Dobs, as to some means of relieving the poor. The Lord Mayor and the Bishop got. together a committee of twenty-four, and (as Holinshed records) ${ }^{1}$ :

In the end, after sundrie meetings (for by meane of the good diligence of the bishop it was well followed), they agreed vpon a booke that they had deuised, wherein they first considered of nine speciall kinds and sorts of poore people, and those same they brought in these three degrees :-

Three degrees of poore. $\quad\left\{\begin{array}{l}\text { The poore by impotencie. } \\ \text { Poore by casualtie. } \\ \text { Thriftless poore. }\end{array}\right.$

1. The poore by impotencie are
also diuided into three kinds,
that is to saie:

2. The poore by casualtie are of $\left\{\begin{array}{l}4 \text {. The wounded souldier. } \\ \text { three kinds, that is to saie : The decaied householder. } \\ 6 \text {. The visited by greeuous disease. }\end{array}\right.$

3. The thriftless poore are three $\left(\begin{array}{l}\text { 7. The riotor that consumeth all. } \\ 8 \text {. The vagabond that will abide in }\end{array}\right.$ kinds in likewise, that is to saie : no place.

9. The idle person as the strumpet and others.

We have hitherto been so impressed with the danger of increasing the number of the 'thriftless poor,' that we have managed to exercise a degrading and demoralising effect on ' the poore by impotencie,' and the 'poore by casualtie.' We ought now to try a bolder experiment in what is necessarily

1 Elizabethan England, pp. 122-3. 
our great collective laboratory of individual character. The time has come when we ought to aim at the maintenance and improvement of the character of the aged, infirm, and orphaned poor, rather than content ourselves with the mere repression of 'the vagabond that will abide in no place,' and 'the idle person.'

The former classes must, as far as possible, be removed out of the demoralising circle of the Poor Law system, which might then easily be maintained for the latter in even greater rigour than at present. With this view the following proposals are submitted for discussion as a possible scheme of Poor Law Reform :-

\section{I.-State Pensions for the Aged}

The Poor Law Commissioners did not, in their great Report of 1834, recommend the withdrawal of outdoor relief from the aged or the infirm. The common impression that they advocated the total abolition of outdoor relief is incorrect. The whole drift of their conclusions is against any subsidy in aid of wages ; but they did not regard collective provision for old age as any real allowance in aid of wages, in the sense of wages being likely to be higher if no such provision were made. Modern economists cannot do otherwise than confirm this view.

No determined attempt has accordingly been made, except in London, Manchester, and a few other places, to abolish outdoor relief to the aged, and the statistics already quoted appear to prove that at least one-fourth of the people who attain the age of sixty-five, are compelled to resort to the relieving officer for that bare subsistence upon which they linger out their lives.

Nothing can be more discouraging to thrift and providence than our present practice in such cases. When a man is absolutely destitute we provide for him a bare subsistence. If he can manage to save, by the time he is sixtyfive, as much as $\mathrm{I}_{5} \mathrm{O}$, he can provide for himself and wife 
practically as well as he and she would be provided for if they had saved nothing at all. Once past that minimum, there is every inducement to save which 'gentility' and independence can offer. Anything short of that minimum is virtually of no use at all. Poor Law relief cannot legally be given except to the absolutely destitute, and the aged domestic servant, or farm-labourer, who has accumulated $£_{50}$, must dissipate that small hoard before his future will be secured from want. ${ }^{1}$ The man who has a shilling a week from his friendly society is legally no better off than he who has nothing. ${ }^{2}$ Both must be just kept alive, and legally neither can demand more.

Now the virtual minimum which enables an aged couple to dispense with poor law relief is far beyond the reach of a large proportion of the population. Instead, however, of encouraging them to save as much as they can towards their support, we, in effect, discourage them by making them no better off than those who save nothing at all.

Would it not be better frankly to recognise the provision of a minimum pension for old age as a collective charge? Every person must necessarily pay rates and taxes in one shape or another all his life long. It seems desirable to promote in every way the feeling that 'the Government' is no entity outside of ourselves, but merely ourselves organised for collective purposes. Regarding the State as a vast benefit society, of which the whole body of citizens are necessarily members, the provision of pensions to the aged appears to be an obvious expansion of the Democratic idea.

1 A domestic servant who had, with incredible perseverance and patience, saved up some $£ 60$ or $£ 70$, found this little hoard gradually melting away in her struggle to maintain her respectability, and appeared before the Whitechapel Board of Guardians with the balance, asking what she should do. Legally the Board could have given no relief until the amount was dissipated. Ultimately an adequate annuity was privately purchased for her, the extra sum required being found by subscription.

2 So absurd is this legal discouragement of thrift, that a practice is growing up of allowing half of any such pension to benefit the pauper-thus, if he has two shillings a week from his club, the normal relief is reduced only by one shilling. This illegal expedient is connived at by the Local Government Board. 
The German scheme of national insurance, ${ }^{1}$ the proposals in England of Canon Blackley, the pension experiment of the Whitechapel Guardians, and the growing feeling in favour of greater generosity to the aged paupers, are alike signs of the drift of public opinion in this direction.

At present we give a superannuation allowance to about 200,000 retired civil servants, military and naval officers and men, policemen, postmen, etc. The system is being extended to elementary school teachers and nurses and to municipal and Poor Law officials. In all these cases the pension is given practically as a matter of right; it is granted in addition to whatever may have been saved by the recipient; and it carries with it no stigma of public disgrace.

We also give what are virtually superannuation allowances to over 300,000 aged paupers, besides workhouse accommodation to over 100,000 more. In their case the pension is awarded as of grace on the part of a committee of those who are often regarded as their life-long industrial opponents; it is only awarded where there are no savings, or where the savings have been consumed; and it is accompanied by public opprobrium and legal disqualification for the duties of citizenship.

The result in the first case is to encourage thrift and saving to supplement the pension, without the slightest demoralisation of character. The result in the second case is absolutely to discourage thrift and saving, and to break down whatever character had survived the losing fight of life. If we intend to give pensions to our aged poor, as we virtually now do, had we not better do so in such a way as to improve rather than to injure their character, and in a manner calculated to promote rather than to discourage their thrift ?

This proposal must not be confounded with schemes of national insurance. The poor of this country will never vote away the poor-rate. The free and independent elector will never submit to the 'regimentation,' identification, and

1 See the German Insurance Laws, by the Rev. W. Moore Ede, and the various Foreign Office and American publications on the subject. 
restrictions on locomotion which any scheme of general insurance must necessarily involve. No Government is at all likely to attempt to collect compulsory insurance premiums from men already supporting their trade unions and friendly societies, their benefit clubs and their building societies, and paying, moreover, a not inconsiderable poorrate. Nor is there any reason for any such collection. The expenditure and the revenue sides of the Budget ought economically to be kept distinct. If aged pensions are desirable let us have them. When the funds come to be raised, let this revenue be obtained according to the classic economic maxims of taxation. It is pretty clear that these maxims will yield no support to the imposition of what would be virtually a new poll-tax.

If any payment at all is required in consideration for the aged pension, it must, as the Rev. W. Moore Ede suggests, ${ }^{1}$ only be as a test of thrift, and a means of improving character. The aged pensions might, at first, be granted only to those persons who (although not in possession of a large income) could show that they had made some attempt partially to provide for their old age. 'It is worth notice that a large number of those compelled in their old age to resort to the workhouse have made ineffectual efforts at thrifty provision for their declining years. In I 88 1 , out of 183,872 inmates of workhouses (one-third being children, and another third women) no fewer than I I,304 had been members of benefit societies. In 39 I 3 cases the society had broken up, usually from insolvency.' ${ }^{2}$ Some public authority, not connected with Poor Law administration, if this is practicable, might be allowed to grant, in lieu of Poor Relief, public superannuation allowances to persons over sixty-five years of age, who had absolutely retired from work, whether destitute or not, who were not notoriously of bad character, and who could show that they had made some continued efforts of thrift, in any form whatsoever. The possession of small savings, continued

1 A Scheme for National Pensions.

2 House of Commons Return, I88 r, No. 444. 
subscription to a friendly society or club, insurance in the Prudential or other society, or lengthy membership of a trade union, co-operative or building society, might all be accepted as relevant evidence of providence. But the object of the measure would be defeated unless the thrift condition were made easy enough to be satisfied by the poorest class of labourers, of merely average foresight and strength of character. At present we fail to encourage thrift because we stigmatise all as semi-criminals who fall below a quite impossible standard. If we really desire to comfort and help the weak-hearted, and to strengthen such as do stand, we must pitch our requirements so as to be within reach of their attainment. Those who do not then fulfil them might be left, as at present, to the tender mercies of the Poor Law. But as those tender mercies are purposely degrading, and consequently demoralising, it should be our object to rescue as many persons as possible from them.

It will at first be contended by members of the Charity Organisation Society on the one hand, and by the officials of friendly societies on the other, that any such public provision of honourable pensions would seriously discourage and thwart the efforts now being made to create private superannuation funds. There is, however, good reason for supposing that this would not be the case. At present these efforts are hindered by the futility of subscribing for anything short of a pension adequate for maintenance. ${ }^{1}$ Anything less than this amount merely goes in aid of the rates, by reducing the amount of relief required. But once let the public pension be independent of other means, and it will become worth while to subscribe for an annuity of even sixpence per week. The great hindrance to thrift at present is the hopelessness of being able to save enough. With a minimum pension

1 "The Manchester Unity has long desired to establish annuity or superannuation benefit funds; to commence at sixty-five is recommended, and not less than 5s. per week. The cost of such a benefit has hitherto proved deterrent." (Evidence of Mr. Watson, actuary to Manchester Unity of Oddfellows, before Committee on National Insurance, H.C. 270, 1885, p. 66.) "After two years, only four members had joined the fund." (Evidence of Mr. Holmes, a director, p. 59.) 
assured, even the smallest addition becomes worth providing. If membership of a friendly society, or a life insurance policy, carried with it almost a certainty of an honourable State pension, instead of degrading Poor Law relief, the strongest possible encouragement would be given to the admirable efforts now being made by the existing popular agencies for thrift, ${ }^{1}$, which are already doing so much for the more prosperous of our artisan classes. At present they do not succeed to any extent in providing for old age. Their benefits for sickness absorb practically all the available savings of the poor. The cost of providing adequate pensions is found to be too serious for the great friendly societies, and for any but a few of the more powerful trade unions. ${ }^{2}$ But small additions to the public pension could at once be made attractive to tens of thousands who could never aspire to obtain even ten pounds a year.

There is a further direction in which these public pensions would encourage individual effort and the creation of character. Nothing is more brutalising than the manner in which the grown-up children of paupers are virtually encouraged to treat their aged parents. The Guardians have the greatest possible difficulty in obtaining contributions from sons towards the maintenance of their pauper parents. The money is given. grudgingly, because it merely saves the rates. But once let it become possible for the poor, as it is for the middle-class and the rich, to soothe and comfort the declining years of their parents by those small gifts which cost so little and mean so much, and we may have at least a chance of awakening those filial feelings which go far to humanise and elevate personal character. If a son's assistance to his Statepensioned father or mother means the addition of tobacco or tea to their bare subsistence, that assistance is a great deal more likely to be given than when it means merely the reduction of his parent's cost to the parish. We deliberately

1 See Dr. Baernreither's English Associations of Working Men; and Report of Committee on National Provident Insurance, H.C. 270 of 1885.

2 Such as the Amalgamated Engineers, Boilermakers, Compositors, etc. 
dry up and starve at present one of the most promising means of developing the higher feelings of the poor.

Some persons will be frightened at the cost of providing any widespread system of aged pensions. It must, however, be remembered that the proposal involves really no new expense to the community. The aged poor are in any case maintained at the cost of the able-bodied workers, and the substitution of pensions for Poor Law relief is merely a readjustment. It may be assumed that in the United Kingdom to-day there would be about 1,700,000 persons over sixty-five. Of these probably 200,000 already receive public pensions of one kind or another, and about 500,000 are in receipt of Poor Law relief, costing, on an average, about $£_{\mathrm{I} 2}$ each annually. What proportion of the others would be eligible for and would apply for a pension, it is impossible to predict. But even if the pension of $\oint_{\mathrm{I}} \mathrm{O}$ per head were made universal (and there is much to be said for this proposal); the extra cost involved would almost be covered by the appropriation to this service of the tax on tobacco, which is not likely otherwise to be allowed to remain as a permanent feature in a Democratic fiscal policy.

If the pension were made payable at seventy years of age, only $2 \frac{2}{3}$ per cent of the population would be alive to claim it, or just a million for the United Kingdom, of whom at least 300,000 are already paupers, and perhaps 100,000 public pensioners. The extra charge involved would, in this case, probably not exceed the tea duty.

But a beginning might be made by sanctioning a certain number of pensions every year, ${ }^{1}$ within a fixed limit, the number being gradually increased so as to absorb more and more of those who would otherwise end their days as paupers. It must never be forgotten that the object of the pension system is not so much the comfort of the individual pensioner as the stoppage of the degradation and demoralisation of the existing pauper class. The main object is to encourage the

1 This is virtually the proposal made in the Bill of Mr. Alfred Thomas, M.P., repeatedly brought before the House of Commons (1890, No. 49). 
salutary discipline of individual thrift by removing the present hopelessness. We must put water into the pump in order to make it draw. ${ }^{1}$

\section{II.-EfFicient EducAtion FOP THE ChildReN}

As the State undertakes to fulfil all the duties of parentage to over 50,000 children (this is the average number of indoor pauper children ; 33,000 of them are actually orphans), and prevents, moreover, any interference of their relations in the matter, it is clear that the State is bound, as a matter both of morality and public policy, to ensure that these duties are fulfilled in the very best possible manner. The Government should, at any rate, set, as a parent, a good and not a bad example.

The grim principle of the 1834 Commissioners, that the pauper's 'situation, on the whole, shall not be made really or apparently so eligible as the situation of the labourer of the lowest class,' cannot be held to apply to orphan children, if the situation of the children of the lowest labourer be such as to be below the level of nurture and education adequate to prepare them for the struggle of life. To manufacture paupers wholesale inside the workhouse, merely because individual parents are doing so outside, has proved too stupid even for the scientific Poor Law pedant, and a vast improvement has taken place in the care of indoor pauper children.

In the best managed institutions little further can, indeed,

1 Since the publication of this proposal in July 1890 , the idea of National Pensions for the Aged, not dependent on any scheme of insurance, has secured widespread and influential approval. This has been mainly due to the support given to the project by Mr. Charles Booth, whose paper, read at the Statistical Society in December $189 \mathrm{I}$, attracted universal attention. It has since been republished, with elaborate statistics, as Pauperism and the Endowment of Old Age (London, 1892). See also Pensions and Pauperism, by the Rev. J. Frome Wilkinson (London, I892), and the significant Minority Report by Mr. Henry Broadhurst, M. P., in Report of the Royal Commission on the Aged Poor (C. - 7604), I895, p. xcix. Bills for granting pensions to all aged persons have been introduced by the responsible Ministries of various Australian colonies, and in New Zealand such a measure was in $1897-98$ passed by the Lower House of the Legislature, but rejected by the Upper House. 
be suggested' so long as we retain the system of herding children in great institutions at all. In the Forest Gate schools, for instance, the elder girls are taken out to market, and taught to buy the provisions which they will afterwards cook for dinner in the separate cottage homes. The boys are often taught shoemaking, tailoring, or the use of some musical instrument. All the girls are put to domestic service. Only about 200 orphans are annually sent to Canada, where they can start in life clear of all old associations.

Boarding out is still restricted, both by its limitation to orphan or deserted children, and by the difficulty of securing efficient supervision, but the 3778 boarded out on Ist July I 888 , had risen to 6498 in 1897 , and, in the great majority of cases, were found to be well cared for.

The facilities for boarding out and emigration, now confined by the order of the Local Government Board to orphans and deserted children, might well be extended to other pauper children, whose parents consented to their being so dealt with. It is even suggested by experienced Poor Law workers that the children of permanent indoor paupers might equally be boarded out, just as they are now sent away to the Poor Law school, without their parents' consent. There is, moreover, much room for improvement in the care of pauper children in the smaller Unions. The indoor pauper children, instead of being herded together in pauper barracks, or crowded in gigantic ophthalmic workhouse schools, as they are in all but a few exceptional institutions, need, if they cannot be boarded out, to be allotted in comparatively small parties in 'cottage homes,' to the care of 'house-mothers.' In the words of the Eleusis Club Report, they should 'be kept free from any pauper taint, sent if possible to mix with other children in good public elementary schools, ${ }^{1}$ and carefully taught some trade or useful occupation, by which they

1 This is already the practice in about a third of the Unions in England and Wales. Moreover, children of outdoor paupers are everywhere required to attend school regularly. 
can fulfil the duties of good citizenship, incumbent on them as on others.' The apprenticeship of pauper children to such practically unskilled trades as hair-cutting, or the placing of them out as errand-boys or farm-labourers, ought to be definitely abandoned.

Their elementary education requires, too, considerable improvement. I6,2 I 6 children were in Metropolitan workhouse schools in I886-87. Out of these only 359 were in Standard VI. (only 22 I of these passed). The inspector deplores 'the bad classification of the older workhouses; the poor and imperfect furniture and appliances provided for educational purposes; the low salaries given, preventing the highest grade of teachers applying for vacant schools; the want of technical skill, and of the ability to impart practical knowledge on the part of industrial trainers ; and the narrow view too frequently taken by Boards of Guardians and managers of utilising the industry of the children.' 1

Ten years have passed since these words were written, and hardly any progress has been made in the elevation of the Poor Law Schools. These remain, even in favourable examples, still far behind a London Board School. ${ }^{2}$

Surely the Education Department might be empowered to insist on these public schools being raised to at least as high a level as an ordinary Board school. It does not seem too much to ask that every child of which the State assumes the duties of parentage should be given, up to fourteen, the best elementary education possible, followed by apprenticeship to some highly skilled trade, so as to ensure that every workhouse child becomes a skilled instead of an, economically speaking, 'unskilled' recruit to the labour market. All this is, however, already within the powers of the Guardians under the existing law; what is needed is the proper spirit and energy in its administration.

1 Report of Local Government Board, C. - 5526, pp. 95-97.

2 During the whole five years' existence of the County Scholarship Scheme of the Technical Education Board of the London County Council, no boy or girl from a Poor Law School has gained any of its 3000 scholarships. 


\section{III.-Collective Provision for the Sick}

Few persons realise how rapidly we are 'municipalising' our hospitals. In the rural districts, the workhouse infirmary is coming to be more and more accepted as the proper home of the wage-earners who are seriously ill, and the prejudice against the removal of the patient from the family is gradually giving way before the improvement of the public hospital. In London in 1889 , where our magnificent voluntary hospitals, 78 in number, provided about 64 I 5 occupied beds, the 27 Poor Law infirmaries and 'sick asylums' had 9639, and the eight hospitals of the Metropolitan Asylums Board I 820, a total of I I 459. Nearly twothirds of our Metropolitan hospital accommodation was therefore provided from public funds. Since that date the publicly administered institutions have greatly increased, whilst the irresponsible and 'voluntary' hospitals have remained stationary or even diminished. Probably three-fourths of the 'occupied beds' are now paid for out of the rates.

Nothing could be more advantageous from the public point of view than that every case of serious illness should be treated in hospital. It is to the public interest that the worker should as quickly as possible recover his health and strength, with the least possible burden to his relations. The great advance in medical treatment during recent years has been in nursing and in antiseptic treatment, neither of which is possible in a crowded home. The isolation of infectious disease is an obvious public gain. But when 80 per cent of our households are those of manual wage-earners, when in our great cities, 30 to 40 per cent exist in single rooms, and as many more in two- or three-room tenements, neither isolation nor proper nursing are possible in the home. The treatment of the sick must necessarily become more and more a matter of collective provision, and it is fortunate that the subjective demoralisation, which we have done our best to attach to it, by making (in London) two-thirds of the inmates technically paupers, is dying away before the 
common sense of the doctors and the patients. It was stated to the House of Lords' Committee that, 'in consequence of the excellence of the treatment in these infirmaries, and their separation from the workhouse, the poor are so ready to resort to them that there is a tendency to regard them as a kind of "State hospital," entrance to which does not imply that the patient is a pauper.' ${ }^{1}$ This excellent discrimination seems so horrible to the Birmingham Guardians, that 'they have determined to make all persons who come to their infirmary pass through the gate which leads to the workhouse grounds, so that they may not draw a distinction between the workhouse and the infirmary.'

This sapient instance of the deliberate 'pauperisation' of those free from this taint is characteristic of far too much of the existing Poor Law administration. We are often so intent on reducing the cost of the collective provision for our poorer brethren, that we even prefer to make that provision as demoralising to them as we possibly can, on the chance that we may thereby exclude (to their detriment and occasional starvation) some of the more dignified among them.

As regards medical aid, however, public opinion is now running too strongly in the other direction to be resisted. By section 7 of the Diseases Prevention (Metropolis) Act I 883, treatment in the magnificent public hospitals of the Metropolitan Asylums Board is not deemed 'parochial relief.' In I 884, Parliament provided that the receipt merely of medical relief should not disqualify a man for exercising the franchise. In the next Parliamentary Registration Bill, a clause will inevitably be carried, which few members of Parliament will dare even to resist, defining 'medical relief' to include treatment in a Poor Law Infirmary or Sick Asylum. Why, moreover, should we deprive a man of the educating dignity of citizenship because he has had the misfortune to have his wife or child compulsorily removed from his care as dangerously insane, and remitted to a public lunatic asylum ?

1 Report of House of Lords' Committee on Poor Law Relief, H.L. 363, 1888, p. viii. 
The question of outdoor medical attendance is less obvious. It may still be possible, by means of provident dispensaries and friendly societies, to enable all persons of ordinary thrift to provide for medical aid in the simple ailments of life. It may, therefore, be desirable not to hinder this spontaneous co-operation, where it exists, by an undue extension of gratuitous medical attendance at the public expense. But there is, in principle, every reason to prefer a frank communism throughout this department of public service, if only public opinion would accept it without subjective demoralisation. The one and only aim in every case of sickness ought to be the quickest possible restoration of the patient to health, and we might well cut our way entirely out of the 'nexus of cash payments' in this if in no other matter of public interest.

The existing distinction between the voluntary and the rate-supported hospital cannot possibly be maintained. There is the most urgent need for the introduction of some order and system into the barbaric chaos of London hospital administration. What appears to be wanted is the complete separation of medical and hospital relief from the Poor Law system. In large cities, the provision for the sick needs classification according to the kind of disease, rather than according to the haphazard distinction of how each particular institution is maintained or administered. We require in London a Central Hospitals Board, managing all public provision for the sick and the insane, and auditing, supervising and controlling all 'voluntary' hospitals. Such a Board would relieve the London County Council of its burdensome care of lunatic asylums, and take over the hospitals of the Metropolitan Asylums Board as well as the workhouse infirmaries and dispensaries. In other counties, it would probably be found sufficient to give similar powers of hospital management and control to the existing 'Asylums Committee' of the County Council, thus removing all provision for the sick from any contact with Poor Law Administration. 


\section{IV.-Public Burial of The DeAD}

It is part of the imperfection of the existing Poor Law statistics that none exist as to the number of pauper funerals. ${ }^{1} \quad$ The proportion of these to the total deaths must, however, be very large. Many persons are buried by the parish who were not in receipt of relief when alive. If I 5 per cent of the deaths in London are those of persons actually in the workhouse or Poor Law infirmary; if over 25 per cent die in some public institution or another; if in the rural districts 30 to 40 per cent of the deaths of persons over sixty are those of paupers; if 25 per cent of those over sixty-five are permanent paupers; it is probable that at least one-third of our funerals are already paid for from Poor Law funds.

To be 'buried by the parish' is felt by the poor to be a disgrace and a dishonour to a greater extent than can easily be realised. The aged labourer, who will rely without shame on the parish doctor, use without disgrace the Poor Law dispensary or infirmary, and even accept without much dishonour the bitter bread of outdoor relief, revolts against the pauper funeral, and starves himself to hoard the sum necessary to avoid this last humiliation. Yet so hard and so demoralising are the conditions of life of the great mass of the population, that it seems probable that at least onethird of them fail to maintain even this "final rally on the narrow ledge' of dignity and self-respect, and are eventually carried down to a pauper's grave.

There is, of course, nothing necessarily degrading in a public funeral. In the case of a soldier, or a sailor, a priest, or a member of a religious order, the collective provision for burial is accepted as a matter of course. It is merely that we have deliberately chosen to make this particular form of public funeral-the lot of one-third of our brethren-an additional anxiety during their lives, a source of bitterness

1 It is a standing disgrace to the statistical department of the Local Government Board that this lack is (1898) still unsupplied. 
during their last moments, and a stain of disgrace to their relations. We have failed in our effort to abolish the public funeral, and have succeeded merely in making it one more pang to the dying, and one more engine of demoralisation to the living. Has not the time come for depauperising our parish funerals? We do not even take the trouble to make the burden easy to the poor. We charge unnecessary and irksome fees for the mere privilege of burial; we permit, in some cases, an absentee rector to levy a toll on all burials from his district, wherever and by whomsoever performed; we allow the provision of cemeteries to become, in many places, a matter of private speculation, and a source of unnecessary individual gain; and we leave the sorrowing household to bargain with a tradesman for their means of performing what is essentially a public duty. There seems no reason why the collective organisation of the people should not be utilised to minimise the trouble and expense of the sepulture of the dead.

In Paris the whole of the cemeteries are public property, and the whole of the funerals are conducted by what is virtually a public organisation. The Company of 'Pompes funèbres' is chartered and subsidised by the municipality, and works under its supervision and control. Funerals are provided according to a definite scale of charges, varying from nothing to the highest amount demanded by Parisian taste. It does not seem an impossible dream that we might one day 'municipalise' our undertakers, expanding the existing 'Burial Boards' into a complete municipal department for interments, the minimum charge being fixed low enough to enable even the very poorest to enjoy the luxury of paying something for the last offices to the loved dead. We might facilitate, instead of obstruct, this final effort of self-respect.

But there is much to be said for going a step further. The expenses of burial must necessarily be shared among the living, and Death knocks at the door of every household, on an average, once in ten years. It is a question whether 
we could not more conveniently 'pool' the necessary minimum costs, and spread the charge over these years, instead of each family meeting it at the time. To quote from a suggestive pamphlet of the Fabian Society ${ }^{1}$ :-

Why should we add to the trouble and economic disturbance necessarily incident to death by levying a toll on burial? The disposal of the dead is a matter of common concern; the fulfilment of this public duty presses crushingly on the poor in their hour of greatest need; 'communism in funerals' is not likely to lead to reckless increase in the demand for graves ; and any simplification of the extravagant expenses now incurred in the matter would be a great boon.

'Free burial' would, moreover, enable the total abolition of infant insurance, with its accompanying evil of infant murder. No valid plea for the insurance of children would remain if the need for individual provision of funeral charges were obviated.

\section{V.-Abolition of the Casual Ward}

For the first 200 years of its history, indeed, during the whole era of the Middle Ages, Poor Law legislation aimed at repression more than at relief, ${ }^{2}$ and we must, to-day, not forget the necessity of undertaking the reformation of sturdy rogues and vagabonds.

Many otherwise good people have a most immoral belief that all paupers belong to this class. They forget that onethird of the paupers are children, one-tenth insane, and onehalf infirm, aged, or disabled adults. Less than one-tenth are classed as able-bodied adults, and of these three-fourths are women, mostly deserted or widowed mothers, with families demanding all their strength. Only $\mathrm{I} \frac{1}{2}$ per cent are classed as usually adult able-bodied males, and even as to these the Local Government Board explains that they include 'those relieved ( $\mathrm{I}$ ) on account of sudden and urgent necessity; (2) on account of their own sickness, accident or infirmity ; (3) on account of the sickness, accident, or infirmity of some

1 Facts for Londoners, p. 53.

2 See Sir F. M. Eden's State of the Poor, and Sir G. Nicholl's History of the English Poor Law. 
member of the family, or of a funeral; and (4) on account of want of work.' 1 The number of vagrants relieved is only about I 3,000 , and the total number of 'sturdy beggars' profiting by the Poor Law must be altogether infinitesimal to the population. Nevertheless, this parasitic class exists in demoralising, and latterly, it would seem, in increasing numbers, moving gaily from one 'Queen's Mansion' to another, until their faces become perfectly well-known to the superintendents.

The existing casual wards appear, indeed, to be permanent foci of moral infection. Filled almost exclusively by habitual tramps, they serve at present merely as the support and increasing degeneration of a hopelessly parasitic class. No relaxation can safely be made in their rigorous dreariness, lest it immediately lead to an influx of inmates eager for the relative luxury. The few innocent persons who drift into the casual ward from she lack of shelter are almost inevitably drawn into the eddy of its evil current, and become permanent casuals. The only reform that can be suggested is the total refusal to recognise or provide for the 'poor traveller,' now become obsolete ; the admission to a 'Reception Ward' of any destitute person, and his searching individual examination there; the stern and rigorous commitment to a penal 'labour colony' of every recognised habitual casual; and the prompt discharge, after performance of a reasonable task of labour, of the merely destitute labourer, who should be in every possible way assisted to obtain employment. We might certainly take as much trouble to save human lives from the shipwreck of permanent pauperism as we do to prevent the loss of ships and cargoes on our coasts.

For the chronic cases of sturdy vagrancy, idle mendicity and incorrigible laziness, we must have recourse to organised pauper labour, strictly disciplined and severely supervised. These classes, like the criminals, are the 'failures' of our civilisation; and while they must be treated with all just

1 Local Government Board Report, C. -8583 of 1897 . 
kindness, and offered opportunities of earning their subsistence, they must nevertheless be sternly denied all relief until they are willing to repay it by useful labour. The present Poor Law system fails to deal with them, and all reformers demand further public action. Mr. Charles Booth urges that we must 'open a little the portals of the Poor Law, or its administration, making within its courts a working guild under suitable discipline,' and eliminate the idle loafers from society by making their existence in the ordinary community more and more impossible, whilst we, on the other hand, offer them constantly the alternative of the reforming 'Labour Colony' to which all incorrigible vagrants and beggars could be committed by the magistrate for specified terms on the indictment of the police or poor-law officer.

There need be no fear that the Democracy will deal tenderly with these fraudulent claimants upon its purse; once provide generously and wisely for all in whose cases the relief is neither dishonourable nor demoralising, and the residuum may safely be treated with scientific rigour.

\section{VI.-REFORM OF POOR LAW MACHINERY}

No Poor Law administration will, however, be stable until those responsible enjoy the confidence of the public, now effectually destroyed by the defective manner of their election. The reform of the administrative machinery of the Poor Law is therefore a matter of vital importance, especially in the metropolis. Indeed, it is probable that this side of the problem will force itself upon the notice of Ministers long before they can be induced to deal with the equally urgent reforms already referred to.

The administration of the Poor Law is committed to 647 boards of guardians, acting for 647 aggregations of I 4,827 parishes. In London there are 30 boards of 
guardians acting either for separate parishes (14), or for 'unions' (I6) of smaller parishes. The 'overseers of the poor,' appointed by two J.P.'s, have become practically obsolete as to function.

In I 890, when this paper was written, the electoral system of the Poor Law. was a public scandal. The boards of guardians were mainly elected by the ratepayers (either annually or triennially in the month of April, according to the particular arrangement in force for each parish) upon a system of plural voting, each elector having from one to six votes, according to the rateable value of his house. Owners were entitled to vote as well as occupiers, and might even vote by proxy, and an occupying owner could give double votes. If, moreover, he was rated for more than one house, whether as a 'house farmer' or not, his voting power was further multiplied in propertion to the number of his houses. Under this system it occasionally happened (as in Bethnal Green in April 1 889) that a minority of the large householders prevailed over the poorer majority. The elections were conducted carelessly, voting papers being left at each house by a policeman, and collected next day, without any safeguards against personation or fraud. Very little public interest was aroused, and only a small proportion of the papers were filled up.

Justices of the peace in any parish were ex-officio members of its board of guardians, but they seldom attended. The Local Government Board might, and in some cases did, nominate additional members. The bulk of the work was left in the hands of the paid officials, and the 'clerk to the guardians'-frequently a local solicitor-was often an official pluralist (as in Chelsea) receiving huge emoluments, and practically beyond control.

We need in our Poor Law representative government 'one man one vote' on the County Council Register, uniform triennial elections, exclusion of all J.P.'s, and other nominated members, abolition of rating qualification, election arrangements on the lines of those for the School Boards, and under 
the Corrupt Practices Act (but allowing, as now for parliamentary elections, though not for municipal elections, meetings, etc., in working men's clubs), and removal of the alleged disability of women under coverture to be guardians or electors of guardians. ${ }^{1}$

Each board of guardians now administers relief, and collects its rates independently of the others; but in London the cost of the maintenance of the poor inside the workhouses, infirmaries and schools, the salaries of Poor Law officials, and the expenses of vaccination, are defrayed from a 'Common Poor Fund,' and divided amongst the parishes in proportion to the rateable value of their property.

The burden of London's poor cannot perhaps be safely wholly shared among London as a whole, in the simple manner in which the cost of London's Elementary Education is apportioned. Nor can the charge for the poor be made a matter of national finance. The grant of Poor Law Relief is necessarily so much a question of local discretion in administration, that local responsibility for excess is necessary to prevent local waste or extravagance. Each locality must be left to bear its own charges, wherever those charges are incurred for relief granted, except in the exact manner. and under the general rules laid down for the common guidance. But the principle of the Common Poor Fund can safely be extended, as regards London, so as to throw upon the central metropolitan authority (besides all its own expenditure) the minimum cost per pauper of all relief granted strictly upon the principles prescribed by it, the minimum cost per pauper of local administrative expenses, the whole cost of guardian elections, and the whole of those numerous charges now thrown upon the local poor rate, but expended by the guardians in pursuance of Act of Parliament, or by other public bodies uncontrolled by them. The 'equalisation' of all these charges would still

1 These proposals were in substance adopted by the Government in 1894, so far as England and Wales were concerned, and embodied in the Local Government Act of that year. 
leave undiminished all existing checks upon local extravagance in the grant of relief.

But any equalisation of the London poor rate requires an efficient central authority, and Mr. Pickersgill's Bill, which received considerable support in the House of Commons in I 889, was inadequate in its recognition of this need. The metropolis sadly needs a central 'Board of Guardians' to manage such part of its Poor Law affairs as requires unity of administration, and to ensure the extinction of the demoralising inequality of treatment which thirty separate administrative boards in one city can never fail to produce. Mr. W. M. Acworth ${ }^{1}$ asks, for instance, with regard to the casual wards :

Why should it be left to the local guardians to decide what task should be set, at what hour discharge should take place, whether the task should first be completed or no, whether the ward should be cellular or associated, for on all these points the widest discrepancies exist at the present moment? At one ward habitual casuals enjoy, without the necessity of an entrance fee of fourpence, all the jovial freedom of a common lodging-house. A short distance off the discipline is so stern that the place is shunned by every one except the bona fide wayfarer, who is unacquainted with the character of the various establishments.

At present, too, the patients in the Poor Law Infirmaries at Marylebone and St. Pancras cost $£_{40}$ and $£_{50}$ per patient respectively, whilst those at Wandsworth and Mile End cost little more than half this amount. The thirtynine separate London workhouses have at present each to provide sufficient separate accommodation for about ten distinct classes of inmates. It is, therefore, not surprising that they fail also to discriminate in their classification between the worthy and the unworthy, the innocent and the hardened. Unity of administration would enable, not only much stricter classification and educational discrimination, but also a relaxation in the treatment of the aged and the worthy, along with sterner discipline in separate establishments for the less deserving classes. The financial economy

1 Report of Poor Law Conference, London, I889. 
of amalgamation, in space, in time, and in money, need only be mentioned.

No reformer would, however, for a moment propose to add any functions or powers to London's only Poor Law organisation, the Metropolitan Asylums Board, which possesses all the electoral and some of the other vices of the late Metropolitan Board of Works. Practically all authorities agree with Mr. Acworth and the Rev. S. A. Barnett in urging the creation of a single Poor Law Council for London, which, like its County Council and School Board, must spring exclusively from the direct election of the people. The election might take place triennially, in the years following those of the County Council elections. The Poor Law Council should retain for itself all power of deciding the principles of administration and of poor relief, delegating to local committees of almoners only the duty of administering and granting relief upon those principles. It would naturally take over all the powers, duties, and property of the Metropolitan Asylums Board, except such as were transferred to the proposed Central Hospitals Board, and also the administration of all workhouses, casual wards, and Poor Law schools. The London Poor Law Council should be placed as near as may be practicable in the same position as regards independence as the London County Council and School Board. Its accounts would still be audited by the Government auditors, and its action strictly confined within its parliamentary powers, but the discretionary authority over the London overseers and boards of guardians, now vested in the Local Government Board, might safely be entrusted to it, as well as other powers of the latter overgrown department.

Outside the Metropolis it appears unnecessary to make any immediate alteration of Poor Law machinery or change in Poor Law areas. The existing 647 Poor Law Unions cannot be disturbed without the most serious readjustments of property, debts, officers, rates, and official machinery. No one would propose to transfer them to the county 
councils, which are quite unfitted for the detailed examination of individual cases which should form the leading feature in Poor Law administration.

Nor can Poor Law administration be made wholly parochial. The I 5,000 parishes in the United Kingdom cannot possibly each have its workhouse, its infirmary, its lunatic asylum, its casual ward, and its labour yard. The parish council may well be empowered to remit cases to the appropriate union institution, and possibly act as a local consultative committee to the board of guardians of the union, and to the public authority administering the aged pensions, but further than this no experienced Poor Law worker would desire to go. To allow the parish council to grant outdoor relief would promptly land us in all the demoralising horrors of the Old Poor Law, and to make each parish maintain its own poor would bring back all the absurdities of the old Law of Settlement, with the inevitable results of 'closed parishes,' demolition of cottages, compulsory removals, litigation, inter-parochial envy, hatred, malice, and all uncharitableness. We must therefore retain, outside London, the Poor Law union with its board of guardians, reformed as to election, the members paid their reasonable travelling expenses, and relieved of their present medley of sanitary and educational functions, at last set free to devote themselves entirely to their task of worthily administering the collective provision for the poorer citizens.

The foregoing tentative proposals for Poor Law reform all proceed, it will be seen, on the lines of 'depauperising,' wherever safely possible, the present collective provision of the community for its weaker members, and of 'democratising' the machinery of its administration. They do not profess to form a complete scheme, dealing, as they do, neither with the ' unemployed' nor the constant Poor Law problem of the widow with young children. No doubt they will strike many people as wild and extremely dangerous. There are those who will say that it is unnecessary to propose any change in the present Poor Law system, and 
unwise to suggest far-reaching schemes of possible reform. There are others who will prefer merely to await an expression of the popular will, before even discussing the question. Both classes will, it may with some confidence be suggested, be neglecting the lessons of Democratic history.

We now see that it was a common error to suppose that the introduction of machinery must diminish the demand for industrial skill. The change which rendered valueless various forms of obsolete dexterity has called into existence a much wider range of higher class labour. It is equally erroneous to imagine that the approach to complete political Democracy is enabling us to dispense with statecraft. It is the fashion of the cynic to describe politicians as mere clerks and servants of the popular will, because their action is necessarily shaped by its voice. True statesmanship, however, will recognise that political Democracy merely changes the terms of the problem. Instead of ignoring the popular desires, as Metternich did, or of dazzling, flattering, and evading the popular will, as (let us say) Lord Palmerston did, it is now the task of the statesman to discern the real aspirations of the 'dim inarticulate' multitude, and to guide and interpret these into safely effective political action.

The main requisite of this task of contemporary statesmanship is political prescience. What it is important to know is, not what the people to-day ask for-that is obvious enough-but what they are going to ask for next year. Once the popular demand has found definite form and general support, it becomes increasingly difficult for even the greatest statesman to modify its course. Resistance, even when well argued, does little more than inflame the agitation and injure the influence of the conscientious opponent of the popular will. The duty of the statesman is always to be at least 'six weeks ahead' of the people's voice ; to foresee the coming demand; to occupy the public mind with a welldevised scheme for carrying out the swelling aspiration; and so to obviate the general support of impracticable, ineffective, 
or unsafe plans, taken up merely because no better had been in time suggested.

To be able to head off the crowd from a dangerous course the statesman must, from the outset, be continually leading them towards the same end, but by safe paths. Democracy is like the House of Commons-it will follow if it is led, not if it is merely resisted. If the Democratic ship is to be steered it must be kept under weigh, and at a good pace ; and he who wants to do the steering must know whence the next gust of wind is coming, and not doggedly turn in its teeth.

It appears increasingly probable that we may be on the eve of as great a revolution in Poor Relief as those of $\mathrm{I} 782$ and I834. Whether this change will be for good or for evil in its effect upon national character largely depends on the manner in which our public leaders meet the popular will. 


\section{CHAPTER VIII}

\section{THE RELATIONSHIP BETWEEN CO-OPERATION AND}

TRADE UNIONISM ${ }^{1}$

WHEN an intelligent foreigner asks me what there is most of interest in Northumberland and Durham, I generally forget the Roman Wall, and sometimes even the magnificent view from Durham Cathedral. The most significant thing to me about Tyneside in 1892 is that there are no fewer than 153 co-operative stores in the Northern Section, and that 470 trade societies flourish between Blyth and Middlesbrough. No other part of the world can show so great a development of the two main forms of industrial democracy. The relation of trade unionism and co-operation is therefore a very fitting subject for consideration at this Tynemouth conference.

It will be unnecessary for me to tell you once more the oft-told tale of the marvellous extension of the co-operative movement. You know all about the million members, the twelve millions of capital, the forty millions of annual trade, and last, but by no means least, the three millions of annual 'dividend.' Nor is it needful that I should dilate upon the progress of trade unionism. Times have changed since it was a crime to belong to a working-class combination, and since trade union secretaries received contributions secretly, by night, in the corner of a field. Trade unionism has had its victories, no less glorious than those of co-operation, and

1 A paper read at a conference of Trade Union Officials and Co-operators, Tynemouth, I $5^{\text {th }}$ August I 892. 
counts now a membership of somewhere between one and two millions of as fervent believers in the advantages of their own organisation as the million co-operators themselves. What is the relation between these two great working-class movements?

Now the first question that we have to settle is whether there is any use in trade unionism at all. Perhaps I ought to apologise for raising such a question before an audience of whom a large proportion will be convinced trade unionists. But I do so because I suspect that some ardent apostles of the co-operative faith still cherish the belief that trade unionism is really unnecessary, and that the workman would be better advised if he gave up all attempts at trade combination and contented himself with the advantages offered by co-operation. I do not know that this view is ever distinctly expressed at the present time. But although not explicitly stated, this view of trade unionism still survives, and sometimes, I suspect, hinders that cordial working together of the two movements which is essential for their well-being. I think it is time that it was clearly realised by all intelligent co-operators, not only that strong trade organisations are absolutely necessary to the worker's wellbeing to-day, but also that no possible extension of the cooperative or even the socialist movement can enable, trade unionism to be dispensed with.

I am here face to face with a difficulty. There are, as you know, within the co-operative movement two distinct forms of co-operative industry. On the one hand we have associations of consumers such as the corn mills, the stores, and the Wholesale Societies, who together transact over 95 per cent of the co-operative trade of the country. On the other hand we have a few associations, not of consumers, but of producers, such as the Eagle Brand Boot Works, at Leicester, or the Slipper Makers' Society at Newcastle. The ideal of the associations of consumers is that of the cooperative or socialist state-the management of industry by salaried officials for the profit of the whole community. The 
ideal of the rival form of industrial co-operation consists of groups of self-governing workers owning alike the instrument and the product of their labour, and competing for profit in the markets of the world. These ideals appear to me antagonistic to each other, and mutually exclusive. But, however that may be, they most assuredly present separate problems, and are as different in their limitations and their advantages as they are in their aims. We must therefore separately consider the relation of trade unionism, first to the self-governing workshop, and then to the store.

Let us suppose, for instance, that the co-operative corn mills in the North of England were owned and managed, not by associations of consumers, but by the workmen now employed in each of them. It is clear that there would, in that case, be no room for the present millers' trade union, and strikes against employers would be unknown. But should we by this social revolution have achieved industrial peace? Our self-governing corn mills would be forced inevitably to adopt one of two courses. The workers in each mill might, in the first place, preserve their entire independence of the other mills, and they would all compete with each other for the custom of the community. This course is, in fact, the one pursued by such associations of producers as already exist. But, unfortunately, this unrestrained competition inevitably leads, in bad times, to the lengthening of the hours of labour of the associated producers and the reduction of their remuneration. Profit disappears, at any rate for a time, and it becomes a question of working longer and for less than before, in order to avoid running at a positive loss and seeing their whole capital disappear. To resist this downward tendency, and to insist on the loss being borne by the capitalist employer, is just the function of the trade union to-day. At present the constant pressure of the customer for lower prices, which competing capitalists can do nothing to resist, is to some extent checked by the dyke of the trade union rate of wages. If this were absent, the capitalist workers would find them- 
selves driven in bad times to lower indefinitely their own standard of life in order to keep intact the capital which they had accumulated.

We should have, in fact, the spectacle on a larger scale of what we to-day call the 'sweating system,' in which the main feature is exactly this unregulated struggle between small masters, or individual workers themselves owning the instruments of production, and competing with each other for a bare subsistence. It will be unnecessary for me to remind you that during the last half-year of. bad trade the workers in the Dunston corn mill would not have been earning even subsistence wages, and in order to save the capital they owned, would have been hawking their flour from door to door at cut-throat prices.

But, on the other hand, the self-governing workshops, if they ever came to be the typical form of co-operative industry, might be wise enough to avoid this disastrous competition by learning a lesson from the American capitalist. We might, in fact, have a 'ring' of flour producers against the consumer. A few years ago there was actually an attempt to form a flour syndicate in the North of England, which broke down through the determined opposition of the mills owned by associations of consumers. If these mills had been owned and governed by the workers in them, they might, in order to avoid the horrors of unrestrained competition, have fallen in with this arrangement. Instead of the spectacle of the sweating system, we should then have before us a gigantic 'ring' or 'combine' of capitalist workers, associated to keep up prices against their customers. We should, indeed, have done away with the Millers' Trade Union, with its modest and legitimate desire to maintain the standard of life of its members. But we should have created in its place a body of monopolists exploiting the public for their own private gain. Industrial conflict would have been replaced by industrial oppression.

But in arguing against the substitution of self-governing workshops for trade union action, we are, in fact, fighting a 
shadow. It will be patent that if the I I 2 workers in the Dunston corn mill themselves owned the $£$ I00,000 capital sunk in that venture, they would simply be a partnership of little capitalists, who would immediately begin to employ non-members as simple wage labourers. Wherever we find the 'self-governing workshop' successful to-day a close investigation shows that the 'self-government' of the workers is a delusion, and that the association consists, in greater or smaller proportion, of capitalist-members who are not workers, and of wage workers who are not members. Moreover, it is significant that the scattered and imperfect attempts to realise the ideal of self-employing groups of workers all occur in the industries which are as yet untransformed by an extensive use of machinery, and by the transaction of business on a large scale.

In short, the Industrial Revolution, now rapidly extending to all industries, has rendered it practically impossible for the worker to own the instruments of production without himself becoming a capitalist, able to live independent of his own labour. The ideal of associations of producers belongs essentially to the time when industry was carried on mainly by hand labour in domestic establishments. We need not dispute the possible educational advantages of the self-governing workshop. . Steam and machinery have killed it as certainly as they have exterminated the hand-loom weaver.

Let us therefore pass on to the relation of trade unionism to the other form of co-operative industry, as carried on by associations of consumers. Unlike the self-governing workshop, the store does not presume to undertake the functions of the trade union. The Newcastle co-operators do not profess to protect the interest of the boilermakers or the shipwrights among their number. But there is often an unconscious assumption among co-operators that the worker would gain more by concentrating all his energies on co-operation than by 'frittering them away' on trade combinations. 
Now we are always being told of what I may call the cash value of co-operative consumption-the hundreds of thousands of pounds distributed every quarter in dividends, the millions saved up out of the accumulation of these. Great and good as is all this side of co-operation, I sometimes think that far too much is made of it. It would be a fatal error if the million members of co-operative societies allowed their comparatively small interests as dividend-receivers for one moment to divert their attention from their much vaster interests as wage-earners and citizens. The dividends of a cu-operator amount on an average to about $£_{3}$ a year, or just about a farthing per hour on his wages. A 'good' co-operator, dealing pretty constantly at the store, will make perhaps double this amount, or a halfpenny per hour of his working time. Now I need not remind you how very easy it is to lose a halfpenny per hour in wages for the want of a strong trade union. Take, for instance, the Amalgamated Society of Carpenters, with its five hundred branches all over the kingdom. Their standard rates of wages vary from $5 \mathrm{~d}$. per hour in some towns up to $9 \frac{1}{2} \mathrm{~d}$. per hour in others-a difference equal to no less than eighteen times as much as the average co-operator makes out of his store. In a score of towns last year the carpenters gained a rise or suffered a fall of a halfpenny an hour on their wages-more than they stood to gain in cash if they could have suddenly sprung at one bound into as successful co-operators as the men of Durham themselves. Or compare the rates of wages earned by members of the Operative Bricklayers' Society in its two hundred branches, which show an equally great divergence. Difference in the cost of living may partly explain why a London bricklayer gets $9 \frac{1}{2} \mathrm{~d}$. an hour, and one at Cromer or Taunton only $5 \mathrm{~d}$.; but it is scarcely difference in the cost of living which makes a Newcastle man get $9 \mathrm{~d}$. an hour and a Sunderland man only $8 \frac{1}{4}$ d., a Stockton man 8 d., and a York man $7 \frac{1}{2}$ d. I do not, of course, contend that these differences are entirely caused by the comparative strength or weakness of the local trade 
union branches. But it is quite certain that the relative strength of local trade unionism is a very large factor in determining the standard rate in industries which extend throughout a country. Co-operators must not, in their zeal for their own movement, lose sight of the vital importance of maintaining, all along the line, the dyke of the standard rate of wages. If the co-operative artisans in any town lag behind their fellows elsewhere, even to the extent of an advance of a farthing an hour which might have been gained by strong trade unionism, they will probably have lost as much in actual cash by the end of the year as they will have gained by all their devotion to the co-operative store. The engineers at Keighley, for instance, a strongly co-operative town, are earning at least IOs. a week less than the engineers at Manchester; a fact which can, I think, only be accounted for by the superior capácity for trade combination exhibited by Lancashire mechanics. It will hardly be maintained that the $£_{5}$ a-year dividend of the Keighley 'good co-operator' is equivalent to the $£_{2} 6$ a-year additional wages earned by the Manchester 'good trade-unionist.' We co-operators point the finger of pity and of scorn at London, as a co-operative desert; but the London rate of wages in the well-organised trades is usually considerably above that of most co-operative towns; and the hundred thousand artisans in the London building trades have just secured, solely through their strong trade unions, and without a strike, a rise in wages more than equa! to all the dividends that the Tyneside artisans will this year draw from their flourishing stores.

I do not mean to deny that the quarterly dividend from the store may not often go further than an equivalent addi-

- tion to weekly wages, and we should, of course, be wrong if we measured either co-operation or trade unionism exclusively by the cash benefits that it secures to its adherents. But both co-operators and trade unionists so frequently refer to this side of the argument that it is necessary to remind each of them of the claims of the other in this respect. Far more 
important in both cases is the moral value of the movement. Wages rise and fall, dividends fluctuate and disappear, but the educational result on the individual remains. No man can be either a good trade unionist or a good co-operator without possessing no small share of all the social virtues. But when we are on the cash value of co-operative consumption it is very important that we should not lose sight of the fact that it amounts to but a small proportion of a mechanic's weekly wages.

Nor must we forget, in this discussion of facts as they are, that the modern advocates of co-operative consumption are as much 'dreamers of dreams' as the more old-fashioned prophets of the self-governing workshop. Those who insist on the necessity for trade unions are often referred to a vague co-operative Utopia, in which the federation of stores and wholesales will have become the universal provider, and consequently the universal employer. In this millennium of universal co-operation, it is urged, the worker may safely be indifferent whether the advantage comes to him in increased wages or in high quarterly "dividends" on his total expenditure. But let us thoroughly realise, once for all, the absolute barriers set by the very nature of things to any universal extension of the store system.

In the first place, the entire export trade, which now employs whole districts of England, is necessarily for ever excluded from the sphere of associations of consumers. Not even Mr. Mitchell ${ }^{1}$ would expect the workers for the export trade to abandon their trade unions in the vain hope that the African negro and the Heathen Chinee will become responsible and conscientious members of a Universal Wholesale Society.

Secondly, there are vast areas of industrial operations for our own consumption, which no mere voluntary association could ever undertake. No one proposes that the railway service of the country, or its network of telegraphs or canals, should be governed by voluntary associations of the customers

1 The late respected Chairman of the Co-operative Wholesale Society. 
or users of these public conveniences. Indeed, who are the customers of these essentially national services, and how could they form themselves into a voluntary representative body of administrators? Where consumption is universal and practically compulsory; as in the case of the post-office, or of a municipal water supply, we have necessarily to choose between a close corporation of monopolists making profit, or the compulsory co-operation of the consumers organised as citizens of the municipality or the State. The alternative to capitalism in these services is not voluntary association of consumers, but State or municipal socialism. ${ }^{1}$ There are, in short, whole sections of the working class whom the store and the Wholesale can never hope to employ.

Supposing, however, that, for the sake of argument, we include under co-operation the compulsory associations of the municipality and State. Then, indeed, we might conceive of a time when the entire industry of the community should be governed by the representatives of the public. But even with this complete elimination of the profit-maker, trade combinations would, it appears to me, still remain a necessary part of social organisation. In our enterprises of national and municipal co-operation, such as the post-office and the supply of gas and water, where no private capitalist reigns, we still find divergence of interest between the community of consumers and its servants. The Leeds gasworkers struck against the gas committee of the Leeds Town Council with just the same fierce sense of injustice as animated the revolt of their fellows against a capitalist gas company in London. Indeed, have we not this very conflict in the store itself-consumers eager for low working expenses and high dividends on the one hand, store managers and assistants anxious for increased salaries and early closing on the other? And as more of the manufacturing industry of the country passes from individual to collective control-whether it be

1 Other limits to the possible extension of voluntary associations of consumers are pointed out in the last chapter of The Co-operative Movement in Greal Britain. 
that of the State, or the municipality, or the store-does it not become ever clearer that this transfer, good and desirable as it is, leaves untouched the fundamental divergence of pecuniary interest between the maker of an article and its consumer? This divergence of interest need not, in a wholly democratised industry, take the form of industrial conflict. What is and will always remain necessary is a due representation of the special requirements of each class of workers. The store committee or the town council, representing the whole body of consumers, will meet in conference the trade union committee, cognisant of the special circumstances of particular branches of production. With the elimination of the private capitalist, intent only on his own gain, and frequently defrauding both the producer and the consumer, the way will be left clear for a peaceful understanding between the officials of the community and the representatives of the trades. But to suggest that a true republic of industry can be achieved by a mere committee of consumers, without adequate representation of the interests of each trade, is, I suggest, to misconceive both the nature of man and the character of democratic government.

I contend, therefore, that the co-operative and trade union movements are the necessary complement of each other. In the co-operative society or the municipality the citizen-consumer unites with his fellows to control and manage for their common benefit as much as possible of the industry which supplies their needs. Their aim must necessarily be to obtain good articles at a low expense of production. But as they themselves are also producers, it is easy for them to realise the truth of Owen's great principle, that the community is in the long run injured, not profited, by any beating down of the standard of life of its members. These same citizen-consumers combine, therefore, among themselves in a second organisation, according to industries, in order that in no case may the heedlessness of the consuming majority depress the condition of the minority in which any one set of producers is bound to find itself. Without 
co-operation, voluntary or municipal, there is no guarantee that any industry will be carried on for the public benefit; without trade unionism there is no security that this public benefit will not be made a source of injury to the minority of producers. Combinations of workers may, therefore, be regarded as a permanent element in the democratic State, whether the control over industry be in the hands of voluntary associations of consumers or in those of the State or municipality itself.

Hitherto we have been describing the limitations of co-operation. But the limitations of trade unionism are even more striking. Trade unionism, even if it became universal, would fail to secure for the workers the rent and profit now made out of their labour. These go at present, under our system of private property, to those who own the land or the machinery, or possess the business talent. The essential principle upon which a standard rate of wages is based cuts it off from sharing in profits just as much as from sharing in losses. Against the rock of economic rent, whether from capital or land, all the storms of trade unionism beat in vain. Something more than mere trade combination is, therefore, required if we are to realise the ideal of a community of workers obtaining the full fruits of their labour. The good trade unionist must supplement his trade unionism by co-operation, local and national, and seek to substitute the community in one or other of its organisations for the private absentee proprietor or rent-receiver. Nor can the community of workers itself allow trade combination to go too far. Any particular trade exists, not for the benefit of the workers employed in it, but for the whole nation. The hand-loom weavers could not have been allowed to decide the question of the introduction of the power-loom. The opinion of a Tyneside shipwright of the last generation would not have been conclusive as to the social utility of iron shipbuilding. And to-day we cannot afford to let the repugnance of the skilled hand-tailor stand in the way of the construction of clothing factories making the utmost use of 
machinery and division of labour. 'In short, the ultimate decision upon trade processes and industrial organisation must inevitably rest, not with the producers of the commodity, but with the consumers of it. We may approve the association of the workers in any particular trade to protect themselves from oppression, whether that oppression comes from an individual capitalist or, as in our post-office, from the heedless neglect of the whole community. But beyond that we cannot go. The combination of producers of a particular article, in order to resist the introduction of machinery, or to raise prices against the community, would be as intolerable a tyranny in the hands of a trade union as in that of a capitalist 'ring.' The vague dream of investing trade unions with control over their respective industries must be dismissed as a false ideal. As a worker the citizen is the servant of the community, not its master. $\mathrm{He}$ is rightfully owner of the means of production, and co-director of the nation's industries, but in his capacity as citizen, not in that of miner or mill-hand. We may rebel against individual ownership of land or capital, but no one would trouble to displace Lord Londonderry in order to set several thousands of little Lord Londonderrys in his stead. We no longer claim the land for the labourer, or the mine for the miner, any more than the school for the schoolmaster, or the sewer for the sewer men. These are the notions of a bygone individualism, as much out of date as peasant proprietorship or the handloom. What we seek to substitute for the personal rule of the private owner or trader is the control not of the trade or class, but of the whole community. The trade union goes, therefore, outside of its legitimate sphere, where it seeks to obtain any further control over the industry of its members than is needed for their maintenance of their standard of life, according to the requirements of their trade or the normal social level of the time. Trade unionists who are nothing but trade unionists are giving up half their rights and half their responsibilities; they are organising only the servant side of their lives, and ignoring that richer sphere 
of collective mastership which is now, in store membership and democratic citizenship, opening out so gloriously before them.

My conclusion, therefore, is that trade unionists and co-operators are in duty bound to swell and maintain each other's organisations in every possible way. The artisan co-operator, who is not also a member of his trade society, is a traitor to all the essential principles of the co-operative faith. The trade unionist who is not a co-operator is hugging his chains as a wage-slave without taking his part in the struggle towards the democratic control of industry. And both trade unionist and co-operator, let me add, are forgetful of their rightful duties and responsibilities unless they are also active citizen politicians, eager to secure their full share of control over those branches of co-operation in which the proper unit of administration is not the store or the trade society, but the municipality or the State.

As between trade unionism and co-operation, great harm is constantly done to both movements by the grudging spirit in which the sphere and work of each is often regarded by eager apostles of the other. It is all very well to be enthusiastic about the virtues of one's own particular panacea, but I hope that the time will very shortly come when no co-operative meeting will omit its meed of praise of the sister movement of trade unionism; and when no gathering of trade unionists will neglect to record its appreciation of the advantages of co-operation. We ought not to be content with sending a formal deputation to each other's annual Congress. Every branch of either movement ought to be avowedly made a recruiting ground for the other. When a workman enters a strange town, and seeks his trade union lodge, there is no reason why his branch secretary should not hand him a card giving the address of the nearest co-operative store, and report his name to the secretary thereof. When the store receives a new member, his address and occupation might, in turn, be automatically passed on to the secretary of the local trades council, for 
report to the trade union concerned. It would be an act of far-sighted generosity if the co-operative society would place such of its committee-rooms as could be spared, gratuitously at the disposal of the local trade unions for their lodge meetings. To make the co-operative store, instead of some low public-house, the home of the local trades council, would be at once a gain to co-operation and to trade unionism. At Nottingham, the Mayor grants the trades council the free use of a room in the Municipal Buildings for its meetings. I should like to hear of the Newcastle Co-operative Society cutting out the crowded beerhouses in the Groat Market in a similar way.

Store committees ought to be in more constant communication with the local trade unions with regard to rates of wages and fair contractors. The store, like the town council, must obviously set a good example to other employers, not a bad one. Co-operators must therefore see to it that they pay in all departments the standard rate of wages of the district; that they work their servants for not more than the standard hours of labours in each industry; and, above all, that they give out no contract to any firm which does not observe the same conditions. These principles cannot be rigidly adhered to without close and frequent communication with the local trade union leaders; and it has been chiefly for want of such communication that a few co-operative stores have in the past unwittingly employed 'rat-shop' printers, or gone to 'sweating' contractors.

I hope that it may become possible for co-operators and trade unionists to recognise a 'union label,' at any rate, for certain articles; and if you would instruct your delegates to the Wholesale quarterly meetings and your own store committees to insist that certain kinds of matches and certain makes of jam should no longer be dealt in by co-operative societies, it would do more to promote proper conditions of labour in these industries than any amount of mere sympathy for the unfortunate producers of 'sweated' articles. Co-operators must not expect to get the full and 
cordial support of ardent trade unionists until they show that they are really in earnest in their crusade against bad employers of labour.

On the other hand the trade unions owe to the store a loyal support. There is, I am sorry to say, too much short-sighted hypocrisy in these matters. The secretary of a trade society, who is paid to organise and agitate in favour of fair conditions of labour, will allow his wife to desert the 'co-op. shop,' and encourage her to buy elsewhere commodities of which the price is a patent label of the sweating system. If the democratic control of industry is to be made really effective, every trade unionist must be an ardent co-operator. And the trade unions must treat the store fairly. As an employer the co-operative society cannot go far beyond the average private capitalist, with whom it has to compete. 'The trade union must not demand more from the store than a willing and honourable observance of the standard rate, whatever that may be. Above all, there must be no taking advantage of the vulnerability to slander against which a co-operative society cannot protect itself. The recent strike of some of the bootmakers in the magnificent new works of the Wholesale, at Leicester, is an instance of what I mean. A certain class of workers chose to feel aggrieved on some pretext so slight that their own union authorities unhesitatingly condemned them. But relying on the desire of the Wholesale to avoid disputes, the malcontents persisted in their demand, and (although it was not granted) caused much inconvenience and loss to the million fellow-workmen who are their employers. To attempt in this way to 'take advantage' of a co-operative society is to be disloyal both to trade unionism and to co-operation.

My appeal to both co-operators and trade unionists alike is, therefore, for mutual recognition of each other's proper sphere. There has been in the past too much division, too much jealousy, too much friction between what are two necessary branches of the same democratic move- 
ment. Now, with a broader understanding of the complementary character of the two movements, a larger-hearted appreciation by the officials of both organisations of each other's difficulties, the wage-earners in each town, organised as consumers, and the workers in each trade, organised as producers, might rapidly become an irresistible twin power for the democratic control of industry. The Parliamentary Committee of the Trade Union Congress, and the Parliamentary Committee of the Co-operative Union, represent to-day to a large extent the same persons, or at least the same families. Whether they regard as their special client the wage-earning trade unionist husband or the housekeeping co-operative wife, it is obvious that their real interests must be identical. Both bodies represent the whole community of manual workers, as opposed to any particular section of it. Both are interested in maintaining a high standard of quality and a high level of workmanship. Both have a struggle to wage with those who, as idle landlords or capitalists, levy a tribute upon the working community without necessarily rendering it any service in return.

Finally, neither can achieve its full development without the loyal co-operation of the other, in those wider social reforms which lie beyond the scope of this paper. It seems to me that the leaders of the trade union and the cooperative movements, with their millions of constituents, have a noble opportunity before them. If they will confer together as to the common needs of the two movements, and loyally support each other in working for these, 'sweating' might rapidly be driven out of the land; excessive hours of labour and other forms of industrial oppression might be made impossible; industry might be freed from taxation, and the labourer from tyranny; and trade unionism and co-operation, each in its own legitimate sphere, would spring forward with a bound to conquests more glorious than any yet achieved. But without a true union based on mutual respect, further progress will be difficult, if not 
impossible. The proper relationship of trade unionism and co-operation is, as it seems to me, that of an ideal marriage, in which each partner respects the individuality and assists the work of the other, whilst both cordially join forces to secure their common end-the Co-operative State. 


\section{CHAPTER IX}

\section{THE NATIONAL DIVIDEND AND ITS DISTRIBUTION ${ }^{1}$}

THE weak point of economic theories as to the distribution of the National Dividend, or aggregate income of the community, is that they habitually ignore the prior determination of the distribution of the Means of Production. It is impossible to work out a consistent and complete theory as to rent, interest, profits, and wages, without first postulating an economically normal distribution of labour, skill, and capital upon the land. Let us therefore attempt a preliminary sketch of this distribution in a state of economic equilibrium.

The annual produce of an advanced industrial community consists of a complex aggregate of commodities and services, produced, under the most diverse conditions, varying indefinitely in advantage. The soil, that great mother of all utility, differs in fertility from field to field and from mine to mine. The other physical conditions of industry, such as climate, temperature, supply of sources of energy, and the like, are of equal variety. Human knowledge and skill, without which all labour is in vain, vary from individual to individual. Capital affords more aid to the hands of the labourer in one position and in one occupation than another. And other monopolies, by no means wholly artificial, interpose, as we

1 In this essay in abstract economics is incorporated the greater part of an article contributed to the Quarterly Journal of Economics for January 1888, entitled 'The Rate of Interest and the Laws of Distribution.' This general view of the theoretic relation between rent, interest, and wages in a condition of perfect competition, is further elucidated and applied to the concrete facts of actual life in Industrial Democracy, part iii. 


\section{Io The National Dividend and its Distribution}

shall see, to an important extent, to prevent equality of return to equivalent toil. It is this inequality of return which is the cause alike of rent, interest, and rent of ability; and our task is now to distinguish them from wages and from each other.

Each worker endeavours to secure a position in which his labour will be applied under the most favourable circumstances, and competes with his brethren throughout the industrial community in a struggle for the fortunate opportunities. But the operation of the "law of diminishing return' prevents them all crowding, like flies on a honey-pot, to the best site. Instead of the whole wealth production being concentrated at one point, the maximum net utility (that is, commodity in proportion to 'efforts and sacrifices') will be found to result from one particular arrangement of labour, skill, and capital upon the land; and it is to this particular distribution of these elements that industrial communities must steadily tend. The ideally perfect arrangement may never be actually reached, since it must be itself constantly changing as the complex conditions of international relations alter. But the play of economic forces causes a steady approximation to this 'line of least resistance,' and it may therefore be assumed as the normal in our theoretic statement.

This normal distribution of the Means of Production, producing the maximum return of utility in proportion to 'efforts and sacrifices,' can be proved mathematically to be that in which the last 'dose' of capital, skill, and human energy, applied at any point, causes as great a return for equivalent labour as the last 'dose' applied anywhere else. The distribution of the means of production over the earth constantly tends to conform everywhere to this law of 'equal returns to the last increments.' 1

Of the main factors in wealth production, one large class - the land and the other physical conditions, such as climate, temperature, or water power-are fixed, as regards position

1 Compare Mathematical Psychics, by F. Y. Edgeworth (London, I88I). 
in space, so as to be almost entirely beyond human control in this respect. In our industrial co-operation, we must therefore bring Mahomet to the mountain, and form the requisite ideal combination by varying the amount of human energy, skill, and capital applied to particular sites. We must of course assume, in this pure theory of economic distribution, that perfect frictionless mobility and universal omniscience prevail throughout the industrial community.

Human energy, in the form of ordinary labour force (omitting for the moment skill and capital), will obviously tend to be so distributed upon the land that the return of commodities produced by the last increment of force applied to any particular field will yield just as much as it would have done if added to that being applied to any other field. The return to the first labour force on the fertile Lothians will be much greater than the return to the first labour force applied to the rocky slopes of Ben Nevis; but it will clearly be economically advantageous not to abandon increased cultivation on the Lothians until the point is reached at which the last increment of labour force produces no more there than the last increment applied in the worst circumstances somewhere else. $U p$ to that point, it would be more advantageous for the worker in the worst circumstances elsewhere to be transferred to the as yet unexhausted Lothians; and there would be a constant tendency for such transfer to take place. In perfect economic equilibrium, the last worker on each field produces the same amount of commodity per working day.

It is not less clear, though less commonplace, that skill or industrial ability of every kind tends to be distributed in an analogous manner. Its ideal economic distribution is equally expressed by the law of 'equal returns to the last increments.' But, as ability must always be 'fixed and embodied' in particular human beings, and as these must each be taken with the défauts de ses qualités, it cannot attain so perfect a mobility as ordinary labour force or capital. Nevertheless, there is a constant tendency for as much 


\section{I 2 The National Dividend and its Distribution}

ability to be employed in each industrial process as can be employed there to greater advantage than elsewhere. So long as the employment of a more skilled workman in any concern would cause a greater increase in the aggregate produce than is caused by his employment elsewhere, there will be a constant tendency for the transfer to take place. The return to the last increments of skill employed will, in economic equilibrium, be equal at all places and in all occupations.

We are now prepared to deal with the distribution of capital, the only remaining factor in wealth production. This, too, can be shown to be expressed by the same law of 'equal returns to the last increments.' Capital will tend to flow towards those opportunities in which its use will afford the greatest return. Each worker will be able to enjoy the assistance of as much as he can effectively demand; and the limit of his effective demand is reached when any further addition to the capital he uses would not result in so great an increase of his product as that final increment of capital would enable some other worker to produce. This limit is reached more quickly in the case of some workers than of others; but it is, in economic equilibrium, reached in every case, since, until this happens, there is some worker in a position to attract additional capital to himself from some other employer, by ceding for its use a larger product than that employer could afford. Conversely, the limit cannot economically be permanently overpassed in any case, since, otherwise, the product caused by the use of the last increment of capital would not be equal to what that portion would produce if applied elsewhere. The worker who could thus employ it to greater advantage would be able to cede a larger product for its use than its former user could afford to cede. We shall see hereafter that this equality of return to the last increments of capital is the true form of the ordinary dictum that 'profits tend to an equality,' so mercilessly exposed by Cliffe Leslie.'

1 T. E. Cliffe Leslie, Essays in Moral and Political Philosophy. 
The combination of the factors of production in a state of economic equilibrium may therefore be declared to be such that the last increments of labour force, skill, and capital in use at any point cause exactly as great an increase in the aggregate produce as those last increments of the factors cause which are in use at any other point.

We are now in a position to determine, within the sphere of abstract economics, the normal distribution of the product of a community in economic equilibrium.

We start from the 'margin of cultivation,' where ordinary labour force is employed on the worst land in use. We must, at the same time, select the corresponding instance as regards skill and capital, so that we may assume as the datum-line the worker using the minimum of skill and capital, engaged in wealth production under the most unfavourable circumstances. It is obvious that the return to his labour is the measure of the wages of similar workers throughout the community. They do not receive more, because, if they did, our contemplated worker would abandon his outpost on the margin of cultivation, to go and compete with them. They do not receive less, or they would leave their positions to take up farms alongside of him. His produce includes no economic rent either for land or skill, for he has none of either which others covet; and, though theoretically it may include a trifle of interest for his minimum of capital, we may ignore this as merely equivalent to that 'gratuitous capital,' such as roads, pavements, and policemen, elsewhere provided free of charge to other producers.

We accordingly reach here a standard of what it will be convenient to call 'economic wages,' to be defined as the return to the labour of the ordinary unskilled worker, with the minimum of capital, on the worst soil at that time in use, and in the worst natural circumstances. This is the true 'margin of cultivation,' on which all economic deductions depend. To this normal level the wages of all unskilled workers tend to come; and from this economic datum-line 


\section{I 4 The National Dividend and its Distribution}

the extra produce known variously as rent, interest, wages of superintendence, or generally as profits or surplus value, must be computed.

Assuming, as Ricardo and apparently Karl Marx always did, an entirely unregulated increase of population, it is evident that this 'economic wages' is coincident with Ricardo's natural or normal wages, and with the wages worked out by Marx as the inevitable result of capitalism; that is to say, the minimum produce upon which the average unskilled labourer will maintain himself sufficiently long to rear a generation to replace him. If, at any moment, the 'economic wages' should be in excess of this minimum, the resulting rapid increase of population would force the worst labourers into still worse positions beyond the former 'margin,' where the return to their work would not be so great. If, on the other hand, it fell below the minimum, there would, ex hypothesi, be a diminution of population, which would allow the worst surviving labourer to move to more advantageous surroundings left vacant by this modern 'Black Death.'

Even Marx, however, did not assert these 'normal wages' to be invariable. The minimum requirements of the labourer were admitted by him to vary with his intellectual and moral condition, and to be capable of change. It seems now more correct to say that the amount of the ' economic wages' determined by the position of the margin of cultivation is only one of the factors on which variations of population depend, and that the position of the margin of cultivation is itself partly determined by the 'standard of comfort,' which each social grade does not willingly abandon. Yet much truth unfortunately still remains in the Ricardian and Marxian theory. The involuntary check on population constantly exercises its frightful influence, especially on the infantile death-rate. The death-rate of 'infants in Bethnal Green is twice that in Belgravia. If the iron hand of capital be uplifted ever so little, so that market wages rise above normal, fewer of the families of the crowded toilers succumb 
to the misery of their lot; and the number of their class automatically rises, so as quickly to bring down wages again. This involuntary and automatic action is a potent factor in keeping down unskilled wages to the minimum level in the slums of our great cities. It is the economic form of Sir Walter Besant's 'law of elevenpence ha'penny.'

It is unnecessary here to pursue the subject of market wages as compared with normal, or of the different remuneration of the various grades of labour. It must suffice to say that 'normal wages' underlie them all, and that any variations from this level are but the result of economic monopoly, temporary or durable, in which other labourers do not share.

It is, however, worth noticing how far the wages class extends. For economic purposes, the share of product (abstraction being made of all 'rent of ability' or other monopoly gains) which remunerates the 'efforts and sacrifices' of all persons who actually co-operate in reproduction, must be, in the theory of distribution, called wages. The separation from one another of the several grades of workers has, here as elsewhere, tended to obscure the uniformity in character of all the productive classes, which was dwelt upon by Jevons. 'Masters' have been in the habit of receiving not 'wages' alone, but 'profits,' which, besides 'rent of ability,' include interest and often land rent. 'Men,' on the other hand, often receive much ' rent of ability' with their 'economic wages.' Inventors usually receive not wages, but payments for royalties and licenses. Accumulators of social capital generally obtain as such no more for their services than absolutely idle inheritors; that is, interest for ever on the capital belonging to them. But we must not be misled by this confusion of names or characters. The services of all those who personally assist the production of utility form-as Jevons pointed outeconomically one great class, as opposed to those who do not contribute to social production. The best terms for the remuneration of these services appear to be 'rent of ability' 


\section{The National Dividend and its Distribution}

and 'economic wages,' since the other persons must live on tribute of some kind, usually, in fact, upon economic rent or interest.

This conception of society is assisted by the development of modern industry. Managers tend more and more to be paid by salary in some vast concern, instead of personally taking the 'profits' of a small one. Such industrial leviathans now employ their own inventors, at regular wages, to invent and design for them. If these industrial monsters do not yet engage persons at weekly wages to accumulate capital for them, it is because their command of surplus value makes abstention from immediate consumption an easy task, not worth escaping by any such 'vicarious atonement.'

With these explanations, we may now leave the share of the aggregate social produce to be known as 'economic wages.' It may be summarily defined as the amount of produce produced by the worker at the margin of cultivation with the minimum capital and skill, multiplied by the number of persons actually assisting in social production of utility in any form, whatever the social rank or grade.

But it is in the classification of the remainder of the aggregate produce that the interest of the problem chiefly lies. That there is any product over and above 'economic wages,' as above defined, is obviously due to the fact that man labours with varying degrees of efficiency. On the ' margin of cultivation,' without skill or capital, the whole of the product is 'economic wages.' Any larger product obtained elsewhere by an equivalent amount of labour must be the result of the employment of more advantageous land, of more effective labour, or of capital. According as it can be ascribed to one or the other of these causes, 'surplus value' 'must be allotted to land rent, to the so-called 'rent of ability,' or to what is, in an economic sense, interest, however widely it may differ from the actual payment for the hire of capital in the market at any particular moment.

Now, as regards the extra produce over that at the 
margin of cultivation, which is due to greater advantages of site, there is no difficulty. Various economists since F. A. Walker have abundantly demonstrated how all the differences fall under the head of 'economic rent.' The economic student will be prepared to include in this term all advantages permanently fixed to any 'immovable,' and doubtless also to extend it to those derived from unchangeable and durable forms of capital, such as ships and some heavy machinery.

We are also enabled to put aside the extra produce due to the superior skill or ability of the worker, over and above the commonest unskilled labourer. This extra produce, due to the superior ability of the mechanic, foreman, manager, doctor, or statesman, is a real economic rent, called 'rent of ability.'1

But there is still variation in the product of equal labour under different circumstances, even after allowing for the economic rent of 'land' and 'ability.' In our complex modern industry, we cultivate other things as well as land, and know how to create value at several removes from the mother earth. The use of capital enables the worker to produce more than he otherwise could, in a degree varying with the particular industry and with the circumstances of industrial development. This surplus is not land rent or 'rent of ability,' for we have already eliminated all resulting from these factors. It is not wages so long as the worker in the worst circumstances is unsupplied with capital equally advantageous, for his scanty product determines 'economic wages' all over the community. Surely the best name for this extra produce, resulting from the use of capital and the enjoyment of special industrial advantages not due to superiority of site or skill, will be simply 'economic interest.'

1 It may, however, be submitted for perfect accuracy that it is only 'within the limits of the same trade or profession,' or at most within competing groups, that the normal remuneration is exactly proportionate to the relative ability as compared with that of the worst worker. As between workers in what Cairnes called 'non-competing groups,' the remuneration 'of the worst worker in each will vary in proportion to the relative final utility' of those kinds of labour,-a conclusion not differing in result from Cairnes's 'Law of Reciprocal Demand,' but not exactly in accordance with the pure 'rent of ability' doctrine. 


\section{I 8 The National Dividend and its Distribution}

We are now in a position to set forth the independent definition of interest, which is necessary to complete the theory of distribution. 'Economic interest' is the amount of produce over and above 'economic wages' which is obtained through the use of capital, upon land at the margin of cultivation by the skill of the worst worker employed in the industrial community, or upon better land with greater skill, after deduction of the economic rent of the land and ability. This obviously exhausts the whole product by the ' rate of interest' in the popular sense; for no such phenomenon would be known.

It is true that the amount of 'economic interest' to be obtained from a given quantity (not value) of capital is an important motive for the accumulation of that capital, and that it is possible that accumulation may diminish where the result of the use of capital falls off. But, unless it can be proved that this is the only motive for accumulation (which it is not), it is clear that it cannot be assumed that the supply of capital is automatically regulated by the return to be obtained from its use, let alone by the current 'rate of interest' on the currency valuation of it.

The definition of 'economic interest' here attempted enables another gap to be filled in the determination of 'profits,' which economists are prone to overlook. Profits actually depend, not only on skill and on the amount of capital employed, but largely also upon opportunity and chance. The constantly changing conditions of the industrial community make the economic position of every member of it to vary from day to day. Mere priority and proximity are constantly found to be as effective guards of temporary monopoly as a patent or a favourable site. The profits of business depend largely upon seizing those frequently recurring separate advantages; and, though this may be claimed as an element of business ability, it is so much a matter of chance that many of these 'windfalls' must be put down as adventitious advantages of the possession of capital, in a certain form, at a particular point of time and space. This 
' rent of opportunity' forms a considerable part of 'economic interest.'

'Economic interest,' as here defined, is expressed by a law similar to the Ricardian law of rent. It varies according to the advantage of the particular capital over that minimum capital employed by the worker at the margin of cultivation. That capital yields theoretically no 'economic interest,' since its amount is so small that it is but the equivalent of capital, the use of which is supplied elsewhere gratuitously to all workers by the community. It may however be objected that the 'law of rent' depends also upon the existence of the "law of diminishing return which has been supposed not to apply to manufacturing industries.' This, however, is clearly erroneous. Capital has its 'law of diminishing return,' as much as land. The man of business making good profits naturally tries to take the fullest possible advantage of his advantageous opportunity, and borrows loan capital to increase his business. But he, like the farmer with his land, finds that, after a certain not invariable point, an addition of capital ceases to enable the labour employed to obtain a proportionately increased return. Up to that point, the increased economy in production is not counterbalanced by disadvantages; and the undertaking increases. This is equally true of agriculture, as the farmer with insufficient capital finds to his cost. But, when the point is reached, the counterbalancing disadvantages begin to exceed the increased efficiency. It is irresistibly argued that, if this were not true of agriculture, we should raise all our corn in the one most fertile valley. It may equally be urged that, if it were not true of manufactures, we should spin all our cotton in the one most favourably situated gigantic mill. If it were not equally true of distributive industry, one huge shop would supply a city. There is a certain limit to the business which any one industrial concern can carry on to greater advantage than its neighbours. Beyond that point, although a still further increase would offer further economies in establishment 
charges and the like, it cannot apparently be obtained on remunerative terms. It is not want of capital, or inability to effect greater economies, that prevents Mr. Whiteley from supplying all London or Sir Thomas Lipton all England. He may probably have reached his point of. maximum economic 'cultivation,' and, though still maintaining his old superiorities, is unable to supply any larger circle of customers to greater advantage than his surviving competitors. The 'economic advantage' of a plot of land, or a ship, or a factory, is subject to narrower limits than those set by its greatest possible productivity. Considerations of distance, of local specialities, of difference in taste, and the personal element, all combine in preventing the 'one-man power' in production. God takes care, the child Goethe was informed, that the trees shall not grow up into the sky; and there is still economic use for those of our factories, hands and brains, as well as of our lands, which are not equal to the best in their respective departments. Those who are most favoured will produce the greatest utility, but even the best of all will find a limit beyond which the humblest may successfully compete with him. Beyond this point, the 'law of diminishing return' becomes patently effective; and though, for instance, there are in London printing establishments varying in magnitude from the proprietor of a hundred machines down to the jobbing compositor with his hand-press, a whole century of competition leaves the various businesses competing with each other on apparently equal terms, for they continue to exist side by side.

It is in this way that capitalist competes with capitalist. The statement is true that, abstraction made of land and ability rent, 'profits' — that is, the return to capital'tend to equality'; but it is equality only of the return to the last increment of capital employed in each case. The possessor of a prosperous mine or business does not go on increasing it beyond the economic 'margin of cultivation' merely because, on an average of the whole capital 
employed, he could still earn the market rate of loan interest. He will not borrow to extend his operations unless the extension itself will yield more than the loan interest on the new capital employed therein. $\mathrm{He}$, like the tiller of the soil, stops at the point where further profit would be a relative loss; and he thus maintains safely the 'economic interest' of the more advantageous earlier undertakings.

We thus see that the aggregate gains of business men, like the incomes of landlords or men of genius, in no way tend to equality either of rate or of amount. They often consist in part of the economic rent of land. They are made up to a still greater degree of the economic rent of ability; and they are completed by 'economic interest,' varying according to each man's opportunity and to the amount (not value) of capital his business can effectively employ. There is no 'tendency to equality' in any of these items, and they vary without reference to each other. There is accordingly no tendency to equality in their aggregates. The amount (and also the proportion of surplus value to wages) varies in each case.

The element of truth in the 'tendency of profits to equality' lies in the two facts, that loan capitals, by the 'law of indifference,' will realise equal loan interests when the circumstances as to risk and other conditions are equal ; and that in a state of economic equilibrium the returns to the last increments of capital, wherever applied, will be equal. It may be shown that these two statements are equivalent, and the abstract determination of the nature and amount of interest will then be complete.

We have seen that the capital of an industrial community in economic equilibrium is so distributed that the last increment of it will result in a return less than the return to any of the earlier increments. The amount of that last return will depend upon the facts of each community, - upon the relative position of the 'margin of cultivation' of land, capital, and ability respectively. When 


\section{The National Dividend and its Distribution}

capital is relatively scarce, so that even the last increment is applied upon fertile land and with considerable ability, the return will be great (and land rent and rent of ability will be small). As capital increases, and the 'margin of cultivation' for its employment retreats, the return to the last increment will be less (and land rent or rent of ability, or both, will be greater). It may be added that 'economic wages,' dependent as they are upon the return to labour at the absolute contemporary ' margin of cultivation,' may vary independently of ' economic interest,' though not of economic land rent. The amount of capital relatively to the amount of fertile land and ability may remain stationary, while the population is increasing. In this case 'economic interest' would be stationary, while all the other shares of the product were varying.

Now, the return to the last increment of capital is the most that a lender of capital can normally obtain for its use. The borrower intends to add the borrowed capital to that which he already employs. It then becomes itself the last increment; and its return, by hypothesis not exceeding the return to the former last increment, is the measure of the maximum loan interest that the borrower will pay. At a loan interest a shade less in amount, it will pay him to extend his business; and he will borrow. At a shade more, he will prefer to stand on the old lines. The normal amount of loan interest will therefore be the return to the last increment of capital within the community; and, by the law of 'indifference,' this will tend to equality throughout the community. If this return induces an increase of capital, the effect upon 'loan interest' depends upon the facts of the community. If all the additional capital can be employed so as to produce a return only fractionally less than the return to the previous 'last increment,' the normal loan interest will fall only to that small extent, however much the increase of capital may be. If it produces more (e.g. by a simultaneous increase of ability or improved fertility), the normal loan interest will rise, in spite of the increase of 
capital. These tendencies usually coexist, and the normal loan interest is the resultant.

We have hitherto spoken of the amount of interest, and not the rate. The return to capital is not currency, but commodities. The valuation of the capital, and the valuation of the commodities obtained by its use is an entirely different and subsidiary problem, not affecting the principles of distribution. The American railways do not produce more utility because their stock is 'watered': the amount of capital and the return to that capital remain unaffected by even the most ingenious of bookkeeping transactions. The real inducement to save the amount of capital called $£$ I oO is not a nominal rate per cent, but (among other objects) the amount of commodities to be obtained by its use; and this depends in no way upon the number of pieces of metal or paper at which the capital and the interest may be assessed.

If these views be correct, the principles upon which the economic classification of the produce must be determined are complete and mutually consistent. The amount of produce obtained by the labour of the man at the margin of cultivation, with the minimum capital and ability, sets the standard of normal wages throughout the community. The excess produced owing to the greater advantages of better land is economic rent of land. The excess produced owing to the employment of more skilled workers is rent of ability. The excess produced owing to the employment of capital (including the occasional gains due to temporary monopoly or other commercial advantage) should be called 'economic interest.' The three latter elements all follow the 'law of diminishing return,' and depend upon the position of the 'margin of cultivation' of land, ability, and capital respectively; and this position results from the economic facts of the particular community at any given time.

We are thus brought to a view of the economic nature of interest, and of the circumstances determining its amount, 


\section{The National Dividend and its Distribution}

which, although not absolutely original, differs widely from current doctrines. What the economic lecturer still ordinarily teaches, and what public opinion still commonly believes, was lucidly expressed by F. A. Walker ten years ago, as the uncontroverted conclusion of economic science. 'Interest,' he unhesitatingly observed, 'is to be deducted as the remuneration for the use of capital, its amount being determined by the relation of supply and demand, but always tending, through the operation of a natural law on which all economists, from Adam Smith down, have delighted to dwell, towards a minimum, - the minimum, in the case of interest, being that rate which will induce the possessors of wealth to refrain from consuming it for the immediate gratification of their tastes and appetites, and to save and store it up to the extent of making good the waste and wear of the existing stock of capital and of answering the demands for the enlargement of that stock to meet new occasions for productive expenditure. This condition may imply, in one state of society, an interest rate of eight per cent ; in another, of five; in another, of three. But, whenever the rate is eight per cent, it continually tends to become five; and, whenever it is five, it continually tends to become three, inasmuch as the occasions for an increased expenditure of wealth for productive uses are certain to be transcended, at any given rate of interest, by the rapid accumulations of capital, which go forward by geometrical progression." ${ }^{1}$

Now, though this theory of interest has been repeated by nearly all the English economists, from Ricardo down to Cairnes, it does not seem to have occurred to any one of them that, even assuming it to be correct, it affords no such sufficient determination of the share of interest, in relation to the other shares of the annual produce, as would warrant us in accepting it as adequate for a theory of distribution. It is one of the acute remarks of Henry George that, 'in the current statement, the laws of distribution have no common centre, no mutual relation; they are not the corresponding

1 Quarterly Journal of Economics, April 1887. 
divisions of a whole, but measures of different qualities.' ${ }^{1}$ The current doctrine of interest, as here applied in a theory of distribution, is, in fact, another surviving remnant of those obsolete economic errors which incited Mr. George's eloquent but ill-judged onslaught. It has no 'mutual relation' with the laws of rent, wages, and rent of ability. It is not defined in the same terms. It is by no means apparent that it exactly completes the annual sum of produce to be divided. Let us suppose that there is an exceptionally large produce due to natural causes one year: does the surplus go.to rent, interest, rent of ability, or wages? The problem to be solved is the classification of the produce of each year, and the laws of distribution must all be given in similar terms, so as theoretically to account for the whole annual product, and to account for it with scientific exactness.

Many other criticisms on the theory of interest might be made, did time permit. It might he observed, for instance, that, whereas rent, wages, and rent of ability are defined as amounts, interest is spoken of as a 'rate.' But we are concerned with dividing an aggregate amount; and the law of interest must therefore be given in terms of quantity, and not in terms of a percentage upon an element outside the problem, such as the pecuniary valuation of the capital stock, which itself depends upon the current rate of interest. This leads to considerations of a very complex character, ${ }^{2}$ and it is clear that the amount of the produce to be assigned to interest is not thereby determined.

But the theory has been attacked in an even more fundamental point. It can by no means be admitted that the accumulation of capital depends solely or even mainly upon the rate of interest. Economists have always laid stress upon the other motives for thrift, which led, for instance, the

1 Progress and Poverty, book iii. chap. vii. A more elaborate and scientific criticism on the same lines will now be found in the History of the Theories of Production and Distribution by Edwin Cannan (London, 1893).

2 See, for instance, Principles of Political Economy by Henry Sidgwick (London, I883), book ii. chap. vi. 


\section{The National Dividend and its Distribution}

French peasant up to I 87 I, the Maltese cottager up to I 886 , and the Indian ryot to this day to hoard metallic currency without the inducement of interest at all. The enormous and universal increase of investments in savings banks, where but trifling interest is paid, shows how little the rate affects even the investment of capital. Indeed, there are everywhere a large number of depositors in savings banks who deliberately exceed the limit on which interest is allowed, content to get only safe custody for their savings. And it is now clear that, in certain not unimportant cases, the rate of interest acts partly in a contrary direction, stimulating accumulation. in some directions to a greater degree when the rate is low than when it is high. ${ }^{1}$

The fact is that economists have as yet failed to carry on to interest that powerful economic analysis which they have already applied with so much success to rent, profits, and wages. Throughout the whole science, it is of the utmost importance to distinguish between what are merely scientific categories, not necessarily possessing separate objective existence, and those actual payments from man to man which are often called by the same name. The abstract economist does not deal with the rent actually paid by Farmer Jones to his squire, nor with the wages paid by Jones to his labourers. It is with rent and wages as scientific categories that he is dealing, and he makes abundantly clear to how great an extent the economic rent and wages may differ from the payments popularly known by those names. When he comes to treat of interest, he is content, strangely enough, to confine his view to the actual payment made by the borrower of a certain form of capital to the lender of it. But suppose the lender of it reclaims the loan, and uses the capital himself : does he cease to obtain interest? It may be confidently asserted that, in political economy, interest has no more to do with the lending of capital than rent with the hiring of land, and that the popular 'rate of interest' is no

1 A more complete examination of the relation between interest and the rate of accumulation will be found in Industrial Democracy, part iii. chap. i. 
more the interest with which we are concerned than the annual price of an Irish holding is the 'economic rent' of that particular plot of the earth's surface. It is evident that something more than a reference to the market rate for loans on good mortgage security is necessary, before the doctrine of interest can be brought into line in a complete theory of distribution.

It will be well here to guard somewhat further against what is a serious ambiguity of language. Professor Sidgwick ${ }^{1}$ has already pointed out the difficulty, as well as the necessity, of distinguishing accurately between 'the interest paid to professional lenders of money.' and 'interest in the sense with which we are concerned with it in the theory of distribution.' But there are, in reality, four senses in which the word 'interest' is commonly used, all to be carefully distinguished by scientific economists:-

I. The current rate paid 'in the money market' for short loans of credit or capital in certain forms (chiefly legal tender currency). This is sometimes called the 'rate of discount,' and it depends on the relative supply of the particular form of capital.

2. The current rate paid for more permanent loans on good security. This may conveniently be distinguished as 'loan interest': it varies quite independently of the rate of discount, which it usually exceeds, and it depends on the relative supply of capital in any mobile form seeking durable investment.

3. The normal rate to which the variations in the current rate of 'loan interest' tend to conform over a long period in any community. This is the 'interest' usually dealt with by economists, which 'tends to equality' and to decline.

None of these can be the 'interest' to be defined as a share in the distribution of the annual product, if only because each of them is merely a percentage rate on an arbitrary valuation of an element not within the definition. The interest with which we are concerned must clearly be a definable quantity of produce. This quantity of producethis definite share of the aggregate of commodities and services making up the National Dividend-may conveniently

1 Principles of Political Economy, book ii. chap. vi. 


\section{The National Dividend and its Distribution}

be called 'economic interest.' It is the amount of produce over and above 'economic wages' which is obtained through the use of capital upon land at the margin of cultivation by the skill of the worst worker employed in the industrial community, or upon better land with greater skill after deduction of the economic rent of land and ability.

It is this 'economic interest,' and not the ordinary payment for loan capital, that must be considered as a constituent element in 'profits.' Business profits would equally exist in a community where borrowing was unknown. Unless we are prepared to say that in such a community these 'profits' would exclusively consist of ' rent of ability,' we must admit that their amount could not in that case be affected. 


\section{CHAPTER X}

\section{THE DIFFICULTIES OF INDIVIDUALISM ${ }^{1}$}

OF all the intellectual difficulties of Individualism, the greatest, perhaps, is that which is presented by the constant flux of things. Whatever may be the advantages and conveniences of the present state of society, we are, at any rate, all of us, now sure of one thing-that it cannot last.

\section{The Constant Evolution of Society}

We have learnt to think of social institutions and economic relations as being as much the subjects of constant change and evolution as any biological organism. The main outlines of social organisation, based upon the exact sphere of private ownership in England to-day, did not 'come down from the Mount.'

The very last century has seen an almost complete upsetting of every economic and industrial relation in the country, and it is irrational to assume that the existing social order, thus new-created, is destined inevitably to endure in its main features unchanged and unchangeable. History did not stop with the last great convulsion of the Industrial Revolution, and Time did not then suddenly cease to be the Great Innovator. Nor do the Socialists offer us a statical heaven to be substituted for an equally statical world here present. English students of the last generation were accustomed to think of Socialism as a mere Utopia, spun from the

1 Reprinted, with minor changes, from the Economic Journal for June 1891 . 
humanity-intoxicated brains of various Frenchmen of the beginning of this century. Down to the present generation, every aspirant after social reform, whether Socialist or Individualist, naturally embodied his ideas in a detailed plan of a new social order, from which all contemporary evils were eliminated. Bellamy is but a belated Cabet, Babœuf, or Campanella. But modern Socialists have learnt the lesson of evolution even better than their opponents, and it cannot be too often repeated that Socialism, to Socialists, is not a Utopia which they have invented, but a principle of social organisation which they assert to have been discovered by the patient investigators into sociology whose labours have distinguished the present century. That principle, whether true or false, has, during a whole generation, met with an ever-increasing, though often unconscious, acceptance by political administrators.

Thus, it is the constant flux of things which underlies all the 'difficulties' of Individualism. Whatever we may think of the existing social order, one thing is certainnamely, that it will undergo modification in the future as certainly and steadily as in the past. Those modifications will be partly the result of forces not consciously initiated or directed by human will. Partly, however, the modifications will be the results, either intended or unintended, of deliberate attempts to readjust the social environment to suit man's real or fancied needs. It is therefore not a question of whether the existing social order shall be changed, but of how this inevitable change shall be made.

\section{'Social Problems'}

In the present phase of acute social compunction, the mal-adjustments which occasion these modifications appear to us in the guise of 'social problems.' But whether or not they are the subjects of conscious thought, or conscious action, their influence is perpetually at work, silently or obtrusively modifying the distribution of social pressure, 
and altering the weft of that social tissue of which our life is made. The characteristic feature of our own age is not this constant evolution itself-for that, of course, is of all timebut our increasing consciousness of it. Instead of unconscious factors we become deliberate agents, either to aid or resist the developments coming to our notice. Human selection accordingly becomes the main form of natural selection, and functional adaptation replaces the struggle for existence as the main factor in social progress. Man becomes the midwife of the great womb of Time, and necessarily undertakes the responsibility for the new economic relations which he brings into existence.

Hence the growing value of correct principles of social action, of valid ideals for social aspiration. Hence, therefore, the importance, for weal or for woe, of the change in social ideals and principles which marks off the present generation of Socialists from the surviving economists and statesmen brought up in the 'Manchester School.' We may, of course, prefer not to accept the watchwords or shibboleths of either party ; we may carefully guard ourselves against 'the falsehood of extremes'; we may believe that we can really steer a middle course. This comforting reflection of the practical man is, however, an unphilosophical delusion. As each difficulty of the present day comes up for solution, our action or inaction must, for all our caution, necessarily incline to one side or the other. We may help to modify the social organism either in the direction of a more general Collectivism or in that of a more perfect Individualism; it will be hard, even by doing nothing, to leave the balance just as it was. It becomes, accordingly, of vital importance to examine not only our practical policy but also our ideals and principles of action, even if we do not intend to follow these out to their logical conclusion.

\section{INDIVIDUALISM AND COLLECTIVISM}

It is not easy, at the present day, to be quite fair to the opinions of the little knot of noble-minded enthusiasts who 
broke for us the chains of the oligarchic tyranny of the eighteenth century. Their work was essentially destructive, and this is not the place in which to estimate how ably they carried on their statical analysis, or how completely they misunderstood the social results of the industrial revolution which was falsifying all their predictions almost before they were uttered. But we may, perhaps, not unfairly sum up as follows the principles which guided them in dealing with the difficulties of social life: that the best government is that which governs least; that the utmost possible scope should be allowed to untrammelled individual enterprise; that open competition and complete freedom from legal restrictions furnish the best guarantees of a healthy industrial community; that the desired end of 'equality of opportunity' can be ultimately reached by allowing to each person the complete ownership of any riches he may become possessed of; and that the best possible social state will result from each individual pursuing his own interest in the way he thinks best.

Fifty years' further social experience have destroyed the faith of the world in the validity of these principles as the basis of even a decent social order, and Mr. John Morley himself has told us ${ }^{1}$ that 'the answer of modern statesmanship is that unfettered individual competition is not a principle to which the regulation of industry may be entrusted.'

'It is indeed certain,' sums up Dr. Ingram, at the end of his comprehensive survey of all the economic tendencies, 'that industrial society will not permanently remain without a systematic organisation. The mere conflict of private interests will never produce a well-ordered commonwealth of labour.' 2

Modern Socialism is, accordingly, not a faith in an artificial Utopia, but a rapidly spreading conviction, as yet

1 Life of Cobden, vol. i. chap. xiii. pp. 298, 303.

2 Article 'Political Economy,' in Ency. Brit., ninth edition, vol. xix., 1886, p. 382 ; republished as History of Political Economy. 
only partly conscious of itself, that social health and consequently human happiness is something apart from and above the separate interests of individuals, requiring to be consciously pursued as an end in itself; that the lesson of evolution in social development is the substitution of consciously regulated co-ordination among the units of each organism for their internecine competition $;^{1}$ that the production and distribution of wealth, like any other public function, cannot safely be entrusted to the unfettered freedom of individuals, but needs to be organised and controlled for the benefit of the whole community; that this can be imperfectly done by means of legislative restriction and taxation, but is eventually more advantageously accomplished through the collective enterprise of the appropriate administrative unit in each case ; and that the best government is accordingly that which can safely and successfully administer most.

\section{The New Pressure for Social Reform}

But although the principles of Individualism have long been tacitly abandoned by our public men, they have remained, until quite recently, enshrined in the imagination of the middle-class citizen and the journalist. Their rapid supersession in these days, by principles essentially Socialist, is due to the prominence now given to 'social problems,' and to the failure of Individualism to offer any practicable solution of these. The problems are not in themselves new ; they are not even more acute or pressing than of yore; but the present generation is less disposed than its predecessors to acquiesce in their insolubility. This increasing social compunction in the presence of industrial disease and social misery is the inevitable result of the advent of political democracy. The power to initiate reforms is now rapidly passing into the hands of those who themselves directly suffer from the evils to be removed; and it is therefore not to be

1 See Professor Huxley's pregnant declaration to this effect in the Ninetienth Century, February 1888. Compare D. G. Ritchie's Darwinism and Politics. 
wondered at that social re-organisation is a subject of much more vital interest to the proletarian politicians of to-day than it can ever have been to the University professors or Whig proprietors of the past.

Now the main 'difficulties' of the existing social order, with which Individualist principles fail to deal, are those immediately connected with the administration of industry and the distribution of wealth. To summarise these difficulties before examining them, we may say that the Socialist asserts that the system of private property in the means of production permits and even promotes an extreme inequality in the distribution of the annual product of the united labours of the community. This distribution results in excess in the hands of a small class, balanced by positive privation at the other end of the social scale. An inevitable corollary of this unequal distribution is wrong production, both of commodities and of human beings; the preparation of senseless luxuries whilst there is need for more bread, and the breeding of degenerate hordes of a demoralised 'residuum' unfit for social life. This evil inequality and disastrous malproduction are enabled to continue through the individual ownership of the instruments of industry, one inevitable accompaniment of which is the continuance, in the commercial world, of that personal rule which is rapidly being expelled from political administration. The increasing integration of the Great Industry is, indeed, creatingexcept in so far as it is counteracted by the adoption of Socialist principles-a kind of new feudalism, based upon tenure, not of land, but of capital employed in the worldcommerce, a financial autocracy against which the democracy sullenly revolts. In the interests of this oligarchy, the real interests of each community tend to be ignored, to the detriment of its capacity to hold its own in the race struggle - that competition between communities rather than between individuals in a community which is perhaps now becoming the main field of natural selection.

In examining each of these difficulties in greater detail, 
it will be fair to consider, not only how far they can be solved by the existing order and in what way they are actually being dealt with by the application of Socialist principles, but also what hope might, on the other hand, be found in the greatest possible development of Individualism. For to-day it is the Individualist who is offering us, as a solution of social difficulties, an untried and nebulous Utopia ; whilst the Socialist occupies the superior position of calling only for the conscious and explicit adoption and extension of principles of social organisation to which the stern logic of facts has already driven the practical man. History and experiment have indeed changed sides, and rank now among the allies of the practical Socialist reformer. Factory Acts and municipal gas-works we know, but the voice of Mr. Auberon Herbert, advocating 'voluntary taxation,' is as the voice of one crying in the wilderness.

\section{INEQUALITY OF INCOME}

Inequality in wealth distribution is, of course, no new thing, and it is unnecessary to contend that the inequality of the present age is more flagrant than that of its predecessors. The extreme depth of poverty of those who actually die of starvation is, indeed, obviously no less than before; and when 30 per cent of the five million inhabitants of London are found to be inadequately supplied with the bare necessaries of life, and probably a fourth of the entire community become paupers at sixty-five, it would profit us little to inquire whether this percentage is greater or less than that during the Middle Ages. On the other hand, the wealth production of the community advances by leaps and bounds, being now far greater than ever it was, and greater than that of any other country of the Old World. The riches of a comparatively small number of the owners of our land and capital are colossal and increasing.

Nor is there any doubt or dispute as to the causes of this inequality. The supersession of the Small by the Great 
Industry has given the main fruits of invention and the new power over Nature to a comparatively small proprietary class, upon whom the mass of the people are dependent for leave to earn their living. When it suits any person having the use of land and capital to employ the worker, this is only done on condition that two important deductions, rent and interest, can be made from his product, for the benefit of two, in this capacity, absolutely unproductive classes-those exercising the bare ownership of land and capital. The reward of labour being thus reduced, on an average, by about one-third, the remaining eightpence out of the shilling is then shared between the various classes who have co-operated in the production-including the inventor, the managing employer, and the mere wage-worker-but shared in the competitive struggle in such a way that at least fourpence goes to a favoured set of educated workers, numbering less than one-fifth of the whole, leaving four-fifths to divide less than fourpence out of the shilling between them. The consequence is the social condition we see around us. A fortunate few, owing to their legal power over the instruments of wealth-production, command the services of thousands of industrial slaves whose faces they have never seen, without rendering any service to them or to society in exchange. A larger body of persons contribute some labour, but are able, from their cultivated ability or special education, to choose occupations for which the competition wage is still high, owing to the small number of possible competitors. These two classes together number only one-fifth of the whole. On the other hand is the great mass of the people, the weekly wage-earners, four out of five of the whole population, toiling perpetually for less than a third of the aggregate product of labour, at an annual wage averaging at most $£_{40}$ per adult, hurried into unnecessarily early graves by the severity of their lives, and dying, as regards at least onethird of them, destitute or actually in receipt of poorlaw relief.

Few can doubt the fundamental causes of this inequality 
of condition. The abstraction from the total of over onethird of the product necessarily makes a serious inroad in that which the 'niggardliness of Nature' allows us, and the distribution of the remaining two-thirds is, of course, itself fatally affected by the secondary results of the division into 'two nations' which the private appropriation of rent and interest creates.

\section{Can we Dodge the Là of Rent?}

Individualists may tell us of the good things that the worker could get for himself by thrift and sobriety, prudence and saving, but no economist will for a moment suggest that any conceivable advance in these virtues would remove the fundamental inequality arising from the phenomenon of rent. The mere worker, qud worker, is necessarily working, as far as its own remuneration is concerned, on the very worst land in economic use, with the very minimum advantage of industrial capital. Every development towards a freer Individualism must, indeed, inevitably emphasise the power of the owner of the superior instruments of wealth-production to obtain for himself all the advantages of their superiority. Individualists may prefer to blink this fact, and to leave it to be implied that, somehow or other, the virtuous artisan can dodge the law of rent. But against this complacent delusion of the philanthropist political economy emphatically protests. So long as the instruments of production are in unnrestrained private ownership, so long must the tribute of the workers to the drones continue: so long will the toilers' reward inevitably be reduced by their exactions. No tinkering with the land laws can abolish or even diminish economic rent, however much it may result in the redistribution of this tribute. The whole equivalent of every source of fertility or advantage of all land over and above the worst in economic use is under free competition necessarily abstracted from the mere worker on it. So long as Lady Matheson can 'own' the island of Lewis, and (as she says) do what she likes with her 
own - so long as the Earls of Derby can appropriate at their ease the unearned increment of Bootle or Bury-it is the very emphatic teaching of political economy that the earth may be the Lord's, but the fulness thereof must inevitably be the landlord's.

There is an interesting episode in English history among James I.'s disputes with the Corporation of London, then the protector of popular liberties. James, in his wrath, threatened to remove the Court to Oxford. 'Provided only your Majesty leave us the Thames,' cleverly replied the Lord Mayor. But economic dominion is more subtle than kingcraft_-our landlords steal from us even the Thames. No Londoner who is not a landlord could, under completely free individualism, obtain one farthing's worth of economic benefit from the existence of London's ocean highway; the whole equivalent of its industrial advantage would necessarily go to swell the compulsory tribute of London's annual rental.

It has often been vaguely hoped that this iron law was true only of land, and that, in some unexplained way, the worker did get the advantage of other forms of industrial capital. But further economic analysis shows, as Whately long ago hinted, that rent is a genus of which land rent is only one species. The worker in the factory is now seen to work no shorter hours or gain no higher wages merely because the product of his labour is multiplied a hundredfold by machinery which he does not own.

Whatever may be the effect of invention on the wages of one generation as compared with the last, it has now become more than doubtful to economists whether the worker can count on getting any more of the product of the machine, in a state of 'complete personal liberty,' than his colleague contemporaneously labouring at the very margin of cultivation with the very minimum of capital. The artisan producing boots by the hundred in the modern machine works of Southwark or Northampton gets no higher wages than the surviving hand cobbler in the by-street. The whole differential advantage of all but the worst industrial capital, like 
the whole differential advantage of all but the worst land, necessarily goes to him who legally owns it. The mere worker can have none of them. "The remuneration of labour, as such,' wrote Cairnes in $1874,{ }^{1}$ ' skilled or unskilled, can never rise much above its present level.'

\section{The 'Population Question'}

Neither can we say that it is the increase of population which effects this result. During the present century, indeed, in spite of an unparalleled increase in numbers, the wealth annually produced in England per head has nearly doubled. ${ }^{2}$ If population became stationary to-morrow, and complete personal liberty prevailed, with any amount of temperance, prudence, and sympathy, the present rent and interest would not be affected; our numbers determine, indeed, how bad the margin of cultivation will be, and this is of serious import enough ; but, increase or no increase, the private ownership of land and capital necessarily involves the complete exclusion of the mere worker, as such, from all the economic advantages of the fertile soil on which he is born, and of the buildings, machinery, and railways he finds around him.

\section{The 'Wickedness' of Making any Change}

Few Individualists, however, now attempt to deny the economic conclusion that the private ownership of land and capital necessarily involves a serious permanent inequality in the distribution of the annual product of the community;

\section{Some Leading Principles, p. 348.}

2 Hence the remarkable suppression of "Malthusianism" in all recent economic literature, notably the handbooks of Professors Symes, Cannan, Ely, and Gonner; its significantly narrow subordination in Professor Marshall's Principles of Economics; and the still more significant corrections of that work in the third edition. The birthrate of Great Britain is now apparently lower than it has ever been during the whole of the past century, and it seems tending steadily downwards. The whole subject urgently calls for genuinely scientific investigation from both biological and industrial standpoints. See Industrial Democracy: part iii. chap. i. 
and that this inequality bears no relation to the relative industry or abstinence of the persons concerned. They regard it, however, as impossible to dispossess equitably those who now levy the tribute of rent and interest, and they are therefore driven silently to drop their original ideal of equality of opportunity, and to acquiesce in the perpetual continuance of the inequality which they vainly deplore. It is immoral, we are told, to take any step, by taxation or otherwise, which would diminish even by a trifle the income of the present owners of the soil and their descendants for ever and ever. This cannot be done without sheer confiscation, which would be none the less confiscation because carried out gradually and under the guise of taxation.

The problem has, however, to be faced. Either we must submit for ever to hand over at least one-third of our annual product to those who do us the favour to own our country, without the obligation of rendering any service to the community, and to see this tribute augment with every advance in our industry and numbers, or else we must take steps, as considerately as may be possible, to put an end to this state of things. Nor does equity yield any such conclusive objection to the latter course. Even if the infant children of our proprietors have come into the world booted and spurred, it can scarcely be contended that whole generations of their descendants yet unborn have a vested interest to ride on the backs of whole generations of unborn workers. Few persons will believe that this globe must spin round the sun for ever charged with the colossal mortgage implied by private ownership of the ground-rents of great cities, merely because a few generations of mankind, over a small part of its area, could at first devise no better plan of appropriating its surface.

There is, indeed, much to be said in favour of the liberal treatment of the present generation of proprietors, and even of their children. But against the permanent welfare of the community the unborn have no rights; and not even a living proprietor can possess a vested interest in the existing 
system of taxation. The democracy may be trusted to find, in dealing with the landlord, that the resources of civilisation are not exhausted. An increase in the death duties, the steady rise of local rates, the special taxation of urban ground values, the graduation and differentiation of the income-tax, the simple appropriation of the unearned increment, and the gradual acquirement of land and other monopolies by public authorities, will in due course suffice to 'collectivise' the bulk of the tribute of rent and interest in a way which the democracy will regard as sufficiently equitable even if it does not satisfy the conscience of the proprietary class itself. This growth of collective ownership it is, and not any vain sharing out of property, which is to achieve the practical equality of opportunity at which democracy aims.

\section{Why INEQUALITY IS BAD}

Individualists have been driven, in their straits, to argue that inequality in wealth is in itself a good thing, and that the objection to it arises from the vain worship of a logical abstraction. But Socialists (who on this point are but taking up the old Radical position) base their indictment against inequality, not on any metaphysical grounds, but on the plain facts of its effect upon social life. The inequality of income at the present time obviously results in a flagrant 'wrong production' of commodities. The unequal value of money to our paupers and our millionaires deprives the test of 'effective demand' of all value as an index to social requirements, or even to the production of individual happiness. The last glass of wine at a plutocratic orgy, which may be deemed not even to satisfy any desire, is economically as urgently 'demanded' as the whole day's maintenance of the dock labourer for which its cost would suffice. Whether London shall be provided with an Italian Opera, or with two Italian Operas, whilst a million of its citizens are without the means of decent life, is now determined, not with any reference to the genuine social needs of the capital of the 
world, or even by any comparison between the competing desires of its inhabitants, but by the chance vagaries of a few hundred wealthy families. It will be hard for the democracy to believe that the conscious public appropriation of municipalised rent would not result in a better adjustment of resources to needs, or, at any rate, in a more general satisfaction of individual desires, than this Individualist appropriation of personal tribute on the labours of others.

\section{The Degradation of Character}

A more serious result of the inequality of income caused by the private ownership of land and capital is its evil effect on human character and the multiplication of the race. It is not easy to compute the loss to the world's progress, the degradation of the world's art and literature, caused by the demoralisation of excessive wealth. Equally difficult would it be to reckon up how many potential geniuses are crushed out of existence by lack of opportunity of training and scope. But a graver evil is the positive 'wrong-population' which is the result of extreme poverty and its accompanying insensibility to all but the lowest side of human life. In a condition of society in which the average family income is but a little over $£_{3}$ per week, the deduction of rent and interest for the benefit of a small class necessarily implies a vast majority of the population below the level of decent existence. The slums at the East End of London are the corollary of the mansions at the West End. The depression of the worker to the product of the margin of cultivation often leaves him nothing but the barest livelihood. No prudential considerations appeal to such a class. One consequence is the breeding in the slums of our great cities, and the overcrowded hovels of the rural poor, of a horde of semibarbarians, whose unskilled labour is neither required in our present complex industrial organism, nor capable of earning a maintenance there. It was largely the recognition that it was hopeless to expect to spread a Malthusian prudence 
among this residuum that turned John Stuart Mill into a Socialist ; and if this solution be rejected, the slums remain to the Individualist as the problem of the Sphinx, which his civilisation must solve or perish.

\section{The LosS OF FreEdom}

It is less easy to secure adequate recognition of the next, and in many respects the most serious 'difficulty' of Individualism-namely, its inconsistency with democratic selfgovernment. The Industrial Revolution, with its splendid conquests over Nature, opened up a new avenue of personal power for the middle class, and for every one who could force his way into the ranks either of the proprietors of the new machines or of the captains of industry whom they necessitated. The enormous increase in personal power thus gained by a comparatively small number of persons, they and the economists not unnaturally mistook for a growth in general freedom. Nor was this opinion wholly incorrect. The industrial chains were, in a sense, themselves the result of progress in political liberty. The feudal restrictions and aristocratic tyranny of the eighteenth century gave way before the industrial spirit, and the politically free labourer came into existence. But the economic servitude of the worker did not disappear with his political bondage. With the chains of innate status there dropped off also its economic privileges, and the free labourer found himself in a community where the old common rights over the soil were being gradually but effectually extinguished. He became a landless stranger in his own country. The development of competitive production for sale in the world market, and the supremacy of the machine industry, involved moreover, in order to live, not merely access to the land, but the use, in addition, of increasingly large masses of capital-at first in agriculture, then foreign trade, then in manufacture, and finally now also in distributive industries. The mere worker 
became steadily less and less industrially independent as his political freedom increased. From a self-governing producing unit, he passed into a mere item in a vast industrial army over the organisation and direction of which he had no control. He was free, but free only to choose to which master he would sell his labour-free only to decide from which proprietor he would beg that access to the new instruments of production without which he could not exist.

In an age of the Small Industry there was much to be said for the view that the greatest possible personal freedom was to be obtained by the least possible collective rule. The peasant on his own farm, the blacksmith at his own forge, needed only to be let alone to be allowed to follow their own individual desires as to the manner and duration of their work. But the organisation of workers into huge armies, the directing of the factory and the warehouse by skilled generals and captains, which is the inevitable outcome of the machine industry and the world commerce, have necessarily deprived the average workman of the direction of his own life or the management of his own work. The middle-class student, over whose occupation the Juggernaut Car of the Industrial Revolution has not passed, finds it difficult to realise how sullenly the workman resents his exclusion from all share in the direction of the industrial world. This feeling is part of the real inwardness of the demand for an Eight Hours Bill.

The ordinary journalist or Member of Parliament still says: 'I don't consult any one except my doctor as to my hours of labour. That is a matter which each grown man must settle for himself.' We never hear such a remark from a working-man belonging to any trade more highly organised than chimney-sweeping. The modern artisan has learnt that he can no more fix for himself the time at which he shall begin and end his work than he can fix the sunrise or the tides. When the carrier drove his own cart and the weaver sat at his own loom they began and left off work at the hours that each preferred. Now the railway worker or 
the power-loom weaver knows that he must work the same hours as his mates.

It was this industrial autocracy that the Christian Socialists' of 1850 sought to remedy by re-establishing the 'self-governing workshop' of associated craftsmen; and a similar purpose still pervades the whole field of industrial philanthropy. Sometimes it takes the specious name of 'industrial partnership'; sometimes the less pretentious form of a joint-stock company with one pound shares. In the country it inspires the zeal for the creation of peasant proprietorships, or the restoration of 'village industries,' and behind it stalk those bogus middle-class 'reforms' known as 'free land' and 'leasehold enfranchisement.' But it can scarcely be hidden from the eyes of any serious student of economic evolution that all these well-meant endeavours to set back the industrial clock are, as regards any widespread result, foredoomed to failure.

The growth of capital has been so vast, and is so rapidly increasing, that any hope of the great mass of the workers ever owning under any conceivable Individualist arrangements the instruments of production with which they work can only be deemed chimerical. ${ }^{1}$

Hence it is that irresponsible personal authority over the actions of others-expelled from the throne, the castle, and the altar-still reigns, almost unchecked, in the factory and the mine. The 'captains of industry,' like the kings of yore, are indeed honestly unable to imagine how the business of the world can ever go on without the continuance of their existing rights and powers. And truly, upon any possible development of Individualistic principles, it is not easy to see how the worker can ever escape from their 'beneficent' rule.

1 The estimated value of the wealth of the United Kingdom to-day is 10,000 millions sterling, or over $£$ I 100 per family. The co-operative movement controls about 13 millions sterling. The total possessions of the 31 millions of the wageearning class are less than 250 millions sterling, or not $£ 7$ capital per family. The 8 millions of the population who do not belong to the wage-earning class own all the rest; the death duty returns show, indeed, that one-half of the entire total is in the hands of about 25,000 families. For references to the authorities for these and other statistics quoted, see Fabian Tract, No. 5, Faits for Socialists. 


\section{The Growth of Collective Action}

But representative government has taught the people how to gain collectively that power which they could never again individually possess. The present century has accordingly witnessed a growing demand for the legal regulation of the conditions of industry which represents a marked advance on previous conceptions of the sphere of legislation. It has also seen a progress in the public management of industrial undertakings which represents an equal advance in the field of Government administration. Such an extension of collective action is, it may safely be asserted, an inevitable result of political democracy. When the Commons of England had secured the right to vote supplies, it must have seemed an unwarrantable extension that they should claim also to redress grievances. When they passed from legislation to the exercise of control over the executive, the constitutional jurists were aghast at the presumption. The attempt of Parliament to seize the command of the military forces led to a civil war. Its control over foreign policy is scarcely two hundred years old. Every one of these developments of the collective authority of the nation over the conditions of its own life was denounced as an illegitimate usurpation foredoomed to failure. Every one of them is still being resisted in countries less advanced in political development. In England, where all these rights are admitted, each of them inconsistent with the 'complete personal liberty' of the minority, the Individualists of to-day deny the competence of the people to regulate, through their representative committees, national or local, the conditions under which they work and live. Although the tyranny which keeps the tramcar conductor away from his home for seventeen hours a day is not the tyranny of king or priest or noble, he feels that it is tyranny all the same, and seeks to curb it in the way his fathers took.

The captains of war have been reduced to the position of salaried officers acting for public ends under public control; 
and the art of war has not decayed. In a similar way the captains of industry are gradually being deposed from their independent commands, and turned into salaried servants of the public. Nearly all the railways of the world, outside of America and the United Kingdom, are managed in this way. The Belgian Government works its own line of passenger steamers. The Paris Municipal Council opens public bakeries. The Glasgow Town Council runs its own common lodginghouses, Plymouth its own tramways. The passenger steamboats on the Clyde are run as a public service by the Clyde Navigation Trust. Everywhere schools, water-works, gasworks, dwellings for the people, and many other forms of capital, are passing from individual into collective control. And there is no contrary movement. No community which has once 'municipalised' any public service ever retraces its steps or reverses its action.

Such is the answer that is actually being given to this difficulty of Individualism. Everywhere the workman is coming to understand that it is practically hopeless for him, either individually or co-operatively, to own the constantly growing mass of capital by the use of which he lives. Either we must, under what is called 'complete personal freedom,' acquiesce in the personal rule of the capitalist, tempered only by enlightened self-interest and the 'gift of sympathy,' or we must substitute for it, as we did for the royal authority, the collective rule of the whole community. The decision is scarcely doubtful. And hence we have on all sides, what to the Individualist is the most incomprehensible of phenomena, the expansion of the sphere of government in the interests of liberty itself. Socialism is, indeed, nothing but the extension of democratic self-government from the political to the industrial world, and it is hard to resist the conclusion that it is an inevitable outcome of the joint effects of the economic and political revolutions of the past century.

\section{CoMpetition}

Individualists often take refuge in a faith that the ex. 
tension of the proprietary class, and the competition of its members, will always furnish an adequate safeguard against the tyranny of any one of them. But the monopoly of which the democracy is here impatient is not that of any single individual, but that of the class itself. What the workers are objecting to is, not the rise of any industrial Buonaparte financially domineering the whole earth-though American experience makes even this less improbable than it once was-but the creation of a new feudal system of industry, the domination of the mass of ordinary workers by a hierarchy of property owners, who compete, it is true, among themselves, but who are nevertheless able, as a class, to preserve a very real control over the lives of those who depend upon their own daily labour.

Moreover, competition; where it still exists, is in itself one of the Individualist's difficulties, resulting, under a system of unequal incomes, not merely in the production, as we have seen, of the wrong commodities, but also of their production in the wrong way and for the wrong ends. The whole range of the present competitive Individualism manifestly tends, indeed, to the glorification, not of honest personal service, but of the pursuit of personal gain-not the production of wealth, but the obtaining of riches. The inevitable outcome is the apotheosis, not of social service, but of successful financial speculation, which is already the special bane of the American civilisation. With it comes inevitably a demoralisation of personal character, a coarsening of moral fibre, and a hideous lack of taste.

\section{The Lesson OF Evolution}

This, indeed, is the lesson which economics brings to ethics. The 'fittest to survive' is not necessarily the best, but much more probably he who takes the fullest possible advantage of the conditions of the struggle, heedless of the result to his rivals. Indeed, the social consequences of complete personal liberty in the struggle for existence have 
been so appaling that the principle has had necessarily to be abandoned. It is now generally admitted to be a primary duty of Government to prescribe the plane on which it will allow the struggle for existence to be fought out, and so to determine which kind of fitness shall survive. We have long ruled out of the conflict the appeal to brute force, thereby depriving the stronger man of his natural advantage over his weaker brother. . We stop as fast as we can every development of fraud and chicanery, and so limit the natural right of the cunning to overreach their neighbours. We prohibit the weapon of deceptive labels and trade marks. In spite of John Bright's protest, we rule that adulteration is not a permissible form of competition. We forbid slavery:' with Mill's consent, we even refuse to enforce a lifelong contract of service. We condemn long hours of labour for women and children, and now even for adult men, and insanitary conditions of labour for all workers.

The whole history of social progress is, indeed, one long series of definitions and limitations of the conditions of the struggle, in order to raise the quality of the fittest who survive. This service can be performed only by the Government. No individual competitor can lay down the rules of the combat. No individual can safely choose the higher plane so long as his opponent is at liberty to fight on the lower. In the face of this experience, the Individualist proposal to rely on complete personal liberty and free competition is not calculated to gain much acceptance. A social system devised to encourage 'the art of establishing the maximum inequality over our neighbours' - as Ruskin puts it -appears destined to be replaced, wherever this is possible, by one based on salaried public service, with the stimulus of duty and esteem, instead of that of fortune-making.

\section{The Struggle for Existence between Nations}

But perhaps the most serious difficulty presented by the present concentration of energy upon personal gain is its 
effect upon the position of the community in the race struggle. The lesson of evolution seems to be that interracial competition is really more momentous in its consequences than the struggle between individuals. It is of comparatively little importance, in the long run, that individuals should develop to the utmost, if the life of the community in which they live is not thereby served. Two generations ago it would have been assumed, as a matter of course, that the most efficient life for each community was to be secured by each individual in it being left complete personal freedom. But that crude vision has long since been demolished. Fifty years' social experience have convinced every statesman that, although there is no common sensorium, a society is something more than the sum of its members; that a social organism has a life and health distinguishable from those of its individual atoms. Hence it is that we have had Lord Shaftesbury warning us that without Factory Acts we should lose our textile trade; Matthew Arnold, that without national education we were steering straight into national decay; and finally, even Professor Huxley taking up the parable that, unless we see to the training of our residuum, France and Germany and the United States will take our place in the world's workshop. This 'difficulty' of Individualism can be met, indeed, like the rest, only by the application of what are essentially Socialist principles.

\section{Argument and Class Bias}

These 'difficulties' will appeal more strongly to some persons than to others. The evils of inequality of wealth will come home more forcibly to the three millions of the submerged tenth in want of the bare necessaries of life than they will to the small class provided with every luxury at the cost of the rest. The ethical objection to any diminution in the incomes of those who own our land will vary in strength according, in the main, to our economic or political prepossessions. The indiscriminate multiplication of the 
unfit, like the drunkenness of the masses, will appear as a cause or an effect of social inequality according to our actual information about the poor, and our disposition towards them. The luxury of the rich may strike us as a sign either of national wealth or of national mal-adjustment of resources to needs. The autocratic administration of industry will appear either as the beneficent direction of the appropriate captains of industry, or as the tyranny of a proprietary class over those who have no alternative but to become its wage-slaves. The struggle of the slaves among themselves, of the proprietors among themselves, and of each class with the other, may be to us 'the beneficent private war which makes one man strive to climb on the shoulders of another, and remain there ;' 1 or it may loom to us, out of the blood and tears and misery of the strife, as a horrible remnant of the barbarism from which man has half risen since

We dined, as a rule, on each other :

What matter? the toughest survived.

That survival from an obsolescent form of the struggle for existence may seem the best guarantee for the continuance of the community and the race ; or it may, on the other hand, appear a suicidal internecine conflict, as fatal as that between the belly and the members. All through the tale two views are possible, and we shall take the one or the other according to our knowledge and temperament.

This powcr of prepossession and unconscious bias constitutes, indeed, the special difficulty of the Individualists of to-day. Aristotle found it easy to convince himself and his friends that slavery was absolutely necessary to civilisation. The Liberty and Property Defence League has the more difficult task of convincing, not the proprietary class, but our modern slaves, who are electors and into whose control the executive power of the community is more and more falling. And in this task the Individualists receive ever less and less help from the chief executive officers of the nation. Those

${ }^{1}$ Sir Henry Maine, Popular Government, pp. 49, 50. 
who have forced directly upon their notice the larger aspects of the problem, those who are directly responsible for the collective interests of the community, can now hardly avoid, whether they like it or not, taking the Socialist view. Each Minister of State protests against Socialism in the abstract, but every decision that he gives in his own department leans more and more away from the Individualist side.

\section{SOCIALISM AND LIBERTY}

Some persons may object that this gradual expansion of the collective administration of the nation's life cannot fairly be styled a Socialistic development, and that the name ought to be refused to everything but a complete system of society on a Communist basis. But whatever Socialism may have meant in the past its real significance now is the steady expansion of representative self-government into the industrial sphere. This industrial democracy it is, and not any ingenious Utopia, with which Individualists, if they desire to make any effectual resistance to the substitution of collective for individual will, must attempt to deal. Most political students are, indeed, now prepared to agree with the Socialist that our restrictive laws and municipal Socialism, so far as these have yet gone, do, as a matter of fact, secure a greater wellbeing and general freedom than that system of complete personal liberty, of which the 'sins of legislators' have deprived us. The sacred name of liberty is invoked by both parties, and the question at issue is merely one of method. As each 'difficulty' of the present social order presents itself for solution, the Socialist points to the experience of all advanced industrial countries, and urges that personal freedom can be obtained by the great mass of the people only by their substituting democratic self-government in the industrial world for that personal power which the Industrial Revolution has placed in the hands of the proprietary class. His opponents regard individual liberty as inconsistent with collective control, and accordingly resist 
any extension of this 'higher freedom' of collective life. Their main difficulty is the advance of democracy, ever more and more claiming to extend itself into the field of industry. To all objections, fears, doubts, and difficulties, as to the practicability of doing in the industrial what has already been done in the political world, the democratic answer is 'solvitur ambulando ;' only that is done at any time which is proved to be then and there practicable; only such advance is made as the progress in the sense of public duty permits. But that progress is both our hope and our real aim: the development of individual character is the Socialist's 'odd trick' for the sake of which he seeks to win all others.

Industrial democracy must therefore necessarily be gradual in its development; and cannot for long ages be absolutely complete. The time may never arrive, even as regards material things, when individual is entirely merged in collective ownership or control, but it is matter of common observation that every attempt to grapple with the 'diffculties' of our existing civilisation brings us nearer to that goal. 


\section{CHAPTER XI}

\section{SOCIALISM : TRUE AND FALSE ${ }^{1}$}

I Do not know whether many of those here present are aware that we celebrate to-night what may be regarded as the tenth anniversary of the foundation of this Society. It was on the $4^{\text {th }}$ of January I 884 that the little group, which had been for some months discussing the Regeneration of the World and a Fellowship of the New Life, formally adopted the title of the Fabian Society-thereby indicating, as I take it, an underlying suspicion that the Devil of Individualism was not to be driven out by any short and sharp encounter, but that it behoved all true believers to watch and wait and diligently equip themselves for a warfare which must necessarily be harassing and protracted. But though we took the title of the Fabian Society in January I 884, it was two or three years before we had quite found out what our instinctive choice of a title really portended. In 1884 , the Fabian Society, like the other Socialist organisations, had its enthusiastic young members-aye, and old ones too-who placed all their hopes on a sudden tumultuous uprising of a united proletariat, before whose mighty onrush kings, landlords, and capitalists would go down like ninepins, leaving society quietly to re-sort itself into Utopia. The date for this Social Revolution was sometimes actually fixed for I 889, the centenary of the opening of the French Revolution. I remember myself that one of our friends, in his zeal that Webb.

1 A Lecture delivered to the Fabian Society, 2 Ist January 1894, by Sidney 
the rural districts might not be forgotten, printed and circulated a proposal that a few Socialist missionaries should buy a gipsy caravan and live in it 'until the Revolution,' an event evidently to be expected before the ensuing winter ! ${ }^{1}$

It was against all thinking and teaching of this catastrophic kind that the Society gradually came to set its facenot, as I believe, because we were any less in earnest in our warfare against existing evils, or less extreme in our remedies, but because we were sadly and sorrowfully driven to the conclusion that no sudden or simultaneous transformation of society from an Individualist to a Collectivist basis was possible, or even thinkable. ${ }^{2}$

On the other hand, we had but little sympathy with schemes for the regeneration of mankind by the establishment of local Utopias, whether in Cumberland or in Chili. To turn our back on the Unearned Increment and the Machine Industry seemed a poor way of conquering them. We had no faith in the recuperative qualities of spade husbandry or in any devices for dodging the Law of Rent. In short, we repudiated the common assumption that Socialism was necessarily bound up with Insurrectionism on the one hand or Utopianism on the other, and we set to work to discover for ourselves and to teach to others how practically to transform England into a Social Democratic Commonwealth.

Well, we have, I hope, all learnt a great deal since 1884 , but everything that has happened during these years has strengthened our faith in the fundamental principles of our association. If I might speak in the name of our members, I should say that we are more than ever convinced of the utter impossibility of what may be called Catastrophic

1 Out of enthusiasm of this sort has grown the extremely practical rural propaganda by means of travelling vans, now carried on by various societies. See the interesting annual reports of the 'Red Van' campaigns of the English Land Restoration League for $1892-97$.

2 The process of education amid which the Fabian Society settled down to this view is described in Fabian Tract No. 4r, The Fabian Society: What It has done and how It has done It, by G. Bernard Shaw. 
Socialism, and all its attendant heresies. Nor have we seen reason to alter our distrust of separate Socialist communities, in whatever specious new form the old idea may clothe itself. For ten years we have held on our course, turning neither to Insurrectionism on the one hand nor to Utopianism on the other.

If now I briefly recall to your mind some instances of the progress of Collectivist ideas during these years, I trust that no one will imagine that I am attempting to claim that progress as the work of the Fabian Society, or indeed of any society whatever. Nothing is more futile than to endeavour to ascribe the exact cause and origin of a general intellectual movement, of which we are, indeed, ourselves a product. The seeds of the Socialist harvest of the last few years were sown by the great thinkers and teachers of the last two generations; and it would be idle to attempt.to measure the exact influence of any one of them in the transformation of ideas amid which we are now living.

I take as a starting-point, not I 884 , but the year I 880 , which, as I conceive, approximately marks the turning of thought.

In the year I880 we may almost say that an unsystematic and empirical Individualism reigned supreme. Not in one political party alone, or in one class of society, but in all alike, we find the assumption that the functions of government ought to be reduced to the barest minimum; that free competition, leading as it was supposed to the survival of the fittest, was the only sure foundation of a prosperous State; and that the incessant private 'war which leads each man to strive to place himself on another's shoulders and to remain there,' ${ }^{1}$ was, on the whole, a benevolent dispensation of Providence, and part of the 'Laws of Nature,' not impiously to be interfered with.

The Liberal Party, at that time almost exclusively dominated by the manufacturers and the Whig families, was living on the remnants of the political reputation of the 
Manchester School. A vague belief in the saving grace of non-intervention abroad and laisser faire at home, was vitalised only by a practical programme of the extension of household franchise to the counties. To the rising desire for social reform it presented no more hopeful solution than the economic negations of Nassau Senior and Fawcett. The object of all social reforms, authorised or unauthorised, was to enable the artisan to become a small capitalist, and the labourer a small landowner. 'Three acres and a cow' in the country had its analogue in schemes of leasehold enfranchisement in the towns. As an alternative to the existing order of squires and captains of industry, we had offered to us a millennium of peasant proprietors and small masters. It is needless to enlarge upon the self-complacency with which both Liberal and Conservative capitalists delighted in reminding the working men of all the future possiblities of self-advancement, when land should be 'free,' food cheap, and industrial competition unrestricted. The epics of this faith have been written by that unconscious corruptor of youth, Mr. Samuel Smiles, and are still fresh in the memories of most of us.

In I $880 \mathrm{Mr}$. Gladstone came into power on a wave of popular indignation against atrocities in Bulgaria, which dispensed with the necessity for any programme of social reforms in England. The political Radicals, swept along by the same wave, were too busy denouncing international aggression to be effective even on fiscal reform and political democracy, beyond which they had practically no vision. The Conservatives, less traditionally bound to Administrative Nihilism, had just consolidated the Factory Acts, but their leaders had been so far perverted as deliberately to leave the whole range of sweated trades outside the effective scope of the law and to give up all attempts to shorten the hours of labour. Even the working men had been permeated by the same policy. The Trade Union leaders could think of only four trivial amendments to propose to the Factory Bill of 1878 . The Trade Union Congress of those years asked 
for practically nothing but an Employers' Liability Bill. In I 879 there were a great many more unemployed than there have ever been since, but no responsible authority thought of anything but charity or poor relief for them. Free Education, Extension of the Factory Acts, Limitation of the Hours of Labour, Expansion of Municipal Activity, though all proposed long before, seem, in I 880, scarcely to have entered the heads of any of those who were leading either the Conservative, the Liberal, the Radical, or the Trade Union forces. But more striking even than this barrenness of programme was the total absence of any systematic view of politics as a whole. In this respect the most advanced statesmen of fourteen years ago stood in marked contrast with the Philosophic Radicals of the first half of the century. I will quote the significant comment of a shrewd critic of Mr. Gladstone's Cabinet:

'James Mill and his school had two characteristics which have not always marked energetic types of Liberalism, and perhaps do not mark them in our own day. The advanced Liberals of his time were systematic, and they were constructive. They surveyed society and institutions as a whole; they connected their advocacy of political and legal changes with theories of human nature; they considered the great art of government in connection with the character of man, his proper education, his potential capacities. They could explain in the large dialect of a definite scheme what were their aims and whither they were going. . . . Is there any such approach to a body of systematic political thought in our own day? We cannot say that there is.' ${ }^{1}$

Now, in estimating the progress of Collectivism between I 880 and I 894, I do not propose to make any parade of the membership and influence of the various Socialist societies, which seem to me to be, at the present time, far greater than at any previous period. Nor will I recite a long list of bills which have been passed during the last

1 Mr. John Morley, in a review of Bain's 'Life of James Mill,' Fortnightly Review, vol. xxxi. p. 503 (April 1882). 
fourteen years, and claim these as more or less triumphs of Collectivism. It would be easy to argue that the multiplication of municipal gasworks is an unconscious adoption of the principle of Socialism, just as the freeing of schools and the building of gratuitous libraries is of that of Communism. But what we Socialists are aiming at is not to secure this or that reform, still less to put this or that party into power, but to convert the great mass of the English people to our own views. We are trying to satisfy the ordinary man, not merely that most of the existing arrangements of society are fundamentally defective-for on that point the great majority have always been most painfully convinced-but also that the main principle of reform must be the substitution of Collective Ownership and Control for Individual Private Property in the means of production. In short, the Socialist task is to contribute to this generation the 'body of systematic political thought,' of which Mr. John Morley was in I 882 deploring the lack. Though we cannot count among our ranks any men of the calibre of Bentham and James Mill, though we have neither the wealth nor the position of the Philosophic Radicals of the first part of the century, yet I take it that the work set before us is analogous to theirs. The Socialists are the Benthamites of this generation. And if I had to sum up the effect upon the public mind of the Socialist propaganda of the past fourteen years, I could find no better description than that given of the work of the Benthamites.

'They produced,' says a very competent observer, 'a much more serious effect on public opinion than superficial inquirers perceived, or interested ones would acknowledge. The important practical effect was not made evident by converting and bringing over large numbers of political partisans from one banner or class to another, or by making them renounce one appellation and adopt another; but it was shown by affecting the conclusions of all classes, and inducing them, while they retained their old distinctive names, to reason after a new fashion, and according to 
principles wholly different from those to which they had been previously accustomed.' ${ }^{1}$

It is, of course, especially in the economic and industrial field that we find this reasoning 'after a new fashion, and according to principles wholly different from those to which they had been previously accustomed.' It has become more and more plain that the facts of industrial life are 'dead against' the realisation of the individualist ideal of each man becoming his own master. The Industrial Revolution, with its aggregation of production into ever larger enterprises, has rendered it practically impossible for five-sixths of the population to be anything but hired servants, dependent on the owners of land and capital for leave to earn a living. At the same time, the spread of economic knowledge has made it clear that even the most virtuous artisan cannot dodge the law of rent; and he is therefore left face to face with the grim fact of a colossal tribute levied by ownership upon industry without any obligation on the part of the receivers to render social service in return. It is especially the growing understanding of this Ricardian law of rent which has revolutionised London politics, and has caused the hostile indifference with which the artisan in other centres is coming to regard both the great political parties. The outcome of this new ferment is the formation of an incipient Collectivist body of opinion among the great bulk of the younger men,- the rising London party, and the new-born Labour Movement.

The political effect of this change of opinion is seen in the gradual transformation of party programmes, especially on the Land question. In the Liberal party the new Collectivist section is in direct antagonism to the 'old gang.' Its aim is not the subdivision of property, whether capital or land, but the control and administration of it by the representatives of the community. It has no desire to see the Duke of Bedford replaced by five hundred little Dukes of Bedford under the guise of enfranchised leaseholders, but

\section{J. A. Roebuck.}


prefers to assert the claim of the whole community to the land, and especially to that 'unearned increment' of value which the whole community creates. It has no vain dream of converting the agricultural labourer into a freeholder, farming his own land, but looks to the creation of parish councils empowered to acquire land for communal ownership, and to build cottages for the labourers to rent. The path to its town Utopia is that of Mr. Chamberlain's early career, though not of his political programme-unlimited municipalisation of local public services and a wide extension of corporate activity. London in particular has caught up the old Birmingham cry of 'High rates and a healthy city;' but with a significant difference. Our modern economists tell us that the first source of public revenue for a rising city is the growing rental value of its site, which at present falls into private hands. Hence the new demand for the gradual municipalisation by taxation of urban land values - a demand still so little understood by most of our statesmen that they fondly imagine it to have something to do with a division of rates between houseowner and occupier. It is coming to be remembered, in short, that Bentham himself, the great father of Political Radicalism, urged that taxation need not be limited to the supply of funds for the bare administrative expenses of the State, but that, wisely handled, it also supplied a means of gradually securing the great end of equality of opportunity to every citizen.

The typical young politician, who twenty years ago was a convinced Individualist quoting Mr. Herbert Spencer, is nowadays an empirical Collectivist of a practical kind. His face is turned away from the Individualist ideal of his fathers towards a period of ever-increasing collective action. Happily, however, he is no Utopian, and realises that it is impossible all at once to take over the administration of the land and capital of the community. Where direct public administration is still impracticable, the public interest can only be secured by collective regulation of the conditions of labour, in order to prevent the Standard of Life of the 
workers from being degraded by private greed. And hence it is that the extremely valuable mantle shared by Robert Owen and Lord Shaftesbury, and despised by the older Liberals, is now the joint heritage of the Labour party and the Collectivist Radicals; Eight Hours Bills, practicable and impracticable, are the order of the day, and drastic proposals for the annihilation of 'Sweating' excite the undisguised horror of the older members of both Liberal and Conservative parties. And since all this regulation and supervision of private enterprises is burdensome and expensive, the presumption of the younger politicians is distinctly against individual profit-making where it is possible to dispense with it. The best Government is no longer 'that which governs least,' but 'that which can safely and advantageously administer most.' 1

All this is encouraging progress for so short a period as fourteen years. But it amounts, of course, to no more than the preliminary steps in the conversion of England. Public opinion, in fact, is in ' a fine state to begin on.' Adhesion to Socialism is no longer a disqualification for a candidate. Politicians lend a willing ear to Socialist proposals. Now is the time to bring to bear a body of systematic and constructive political thought, such as that with which the Philosophic Radicals won their great triumphs. The greatest need of the English Socialist Party at this moment is men and women of brains who will deliberately set themselves, by serious study, to work out the detailed application of Collectivist principles to the actual problems of modern life. We need to do a great deal more hard thinking in almost every department of our Socialist programme. I am appalled when I realise how little attention we have yet been able to pay to what I may call the Unsettled Questions of Democratic Administration.

To take, for instance, the pressing problem of the

1 A more detailed account of this change of thought will be found in Fabian Essays in Socialism, the writer's Socialism in England, the History of Trade Unionism, and Industrial Democracy. 
Unemployed. In my humble judgment no plan has yet been devised by which the fluctuations of work could be entirely prevented, or safe and profitable employment found for those rendered idle by no fault of their own. It is easy enough to demand that something should be done; and I entirely agree with agitating the subject; but something more than agitation is required. It is of no use urging remedies which can be demonstrably proved to be worse for the patient than the disease itself. I fear that if we were given full power to-morrow to deal with the unemployed all over England, we should find ourselves hard put to it how to solve the problem. ${ }^{1}$ Or to turn to another field in which practically nothing has yet been done. Have we any clear and decided view as to the relation between central and local authorities? How far do we wish to increase the power of the national administration at the expense of local governing bodies-to what extent, that is, will our Social Democracy be consistent with local Home Rule? The Glasgow Town Council, for instance, is at this moment quarrelling with the Postmaster-General as to whether the telephone shall fall within the sphere of municipal or of national Socialism. It is evident that some departments of public administration can be best managed from one central office. It is, I suppose, equally evident that others must be administered locally, under some kind of central control. But which subjects should be local and which should be central - upon what principle the division should be made, and in what form and to what extent there should be a central control-these are problems to which, as far as I know, no solution has been found and very little serious thought been given.

I do not suggest that we Socialists are more ignorant than other people: on the contrary, the two puzzles that I have chosen are at present puzzles to the whole world. But

1 The student beginning this subject should, as the first step, master the Blue Book of the Labour Department, Agencies and Methods for Dealing with the Un. employed, published October 1893, price Is. 9d. (C. -7182). 
the whole world is not equally interested with ourselves in getting a solution of them. Those who believe that nothing ought to be done for the unemployed are not likely to succeed in finding anything; and we can hardly expect those who object to any extension of Democracy to help us to solve the problems which it presents. It is we who must discover the answers to our own conundrums; and I do most seriously suggest that there is no more valuable field of work for any group of Socialists, no more fruitful service to the Socialist cause, than for them earnestly and persistently to study, in the light of the ascertained facts, some one of the many social problems to which we have to apply our Socialist faith. Depend upon it, the first step to getting what we want is a very clear and precise knowledge of what it is that we want.

But this want of precision in our thinking may easily do worse than merely delay our progress; there is, as it seems to me, a good deal of danger of its leading us positively astray from the Socialist goal. The circumstances of modern life are so complicated, the problems to be dealt with are so difficult, the need for prompt action is often so great that we may easily be led to take up schemes of reform which promise some immediate improvement on the present state of things, but which are not really in the line of advance towards a genuine Collectivism.

Here I venture on dangerous ground. But if we are to clear up our ideas, and apply our Socialist principles to the practical problems of life, we must definitely make up our mind between contrary ideals. If our aim is the transformation of England into a Social Democracy, we must frankly accept the changes brought about by the Industrial Revolution, the factory system, the massing of population in great cities, the elaborate differentiation and complication of modern civilisation, the subordination of the worker to the citizen, and of the individual to the community. We must rid ourselves resolutely of those schemes and projects of bygone Socialisms which have now passed out of date, as well as from the 
specious devices of Individualism in a new dress. All these I class together as spurious Collectivism, making, in my view, not for social progress, but for reaction.

\section{UTOPIA-FOUNDING}

And first let us deal with the ideas of those amiable enthusiasts who are still bent on the establishment of ideal communities. Scarcely a year passes without some new project for the formation of a perfect Socialist colony in Paraguay or Peru, Mexico or Matabeleland, where all the evils of landlordism and the machine industry are to be avoided. The authors of such schemes are often chided for their unbounded belief in human nature. To me, on the contrary, they seem to be throwing up the sponge in despair. Their disgust with the world of competition and Individualism, their impatience with the slow and gradual methods of Democratic progress, come, really not from too much but from too little faith in humanity. 'I see very little hope for the workers as a class,' writes one of them, 'even if they get all they want-our best plan for the present is to form for ourselves a little backwater outside the force of the main current, so that we ourselves may not be entirely swept away-a little space free from the mists and miasma of competition, so that we, at least, may breathe the fresh air of freedom and brotherhood.' ${ }^{1}$

Now I do not for a moment wish to discourage any young Socialist who feels a burning desire to shake the dust of civilisation off his feet. Nevertheless, the aim of the modern Socialist movement, I take it, is not to enable this or that comparatively free person to lead an ideal life, but to loosen the fetters of the millions who toil in our factories and mines, and who cannot possibly be moved to Freeland or Topolobampo. For the last two generations we have had social prophets, who, seeing the impossibility of at once converting the whole country, founded here and there small

\footnotetext{
1 Letter in Brotherhood, January I 894.
} 
companies of the faithful, who immediately attempted to put into practice whatever complete ideal they professed. The gradual adoption of this ideal by the whole people was expected from the steady expansion of these isolated communities. But in no single case has this expectation been fulfilled. Most of these isolated colonies outside the world have failed. Some few, under more favourable circumstances, have grown prosperous. But, whether they become rich or remain poor, they appear to me equally disastrous to the real progress of Socialism inside the world as we know it.

Wise prophets nowadays do not found a partial community which adopts the whole faith; they cause rather the partial adoption of their faith by the whole community. Incomplete reform is effected in the world of ordinary citizens, instead of complete reform outside of it. Genuine Socialism grows by vertical instead of horizontal expansion ; we must make ever more Socialistic the institutions amid which we live, instead of expecting them to be suddenly superseded by any new set imported from elsewhere. By this method progress may be slow, but failure is impossible. No nation having once nationalised or municipalised any industry has ever retraced its steps or reversed its action.

Sometimes, however, the Utopia-founder comes in more dangerous guise. He propounds his scheme, not entirely as a Socialist colony, but as a means of providing for the unemployed. Here is one of the latest of these proposals, put forward by a comrade whom we all respect for sincerity and boundless energy :

\section{The Easiest Way to Socialism}

In the present crisis, with the unemployed clamouring for immediate relief and every humane heart in the country backing their plea, the most suitable and hopeful governmental way of ushering in a Socialistic State is to found for them a partial and optional co-operative commonwealth. This is now, probably, in the present state of public opinion, the most convenient and easy end to begin at; better even than any general scheme of land nationalisation, or the nationalisation of anything else. Let the nation acquire immediately, with public money or public 
credit, just enough of the 6,000,000 untilled or half-tilled acres of the country to set those to work productively who ask for employment; let these, under proper guidance, make some sort of rough dwellings for themselves and their families and one another, grow food, and supply mutually each other's pressing needs; as far as possible, let each man and woman be put to the kind of productive work they have been respectively accustomed to ; and let those who have no skill be trained into usefulness ; let the workers' wages be a draft on the store they help to fill by their labour; let there not be any loss of vote or any slightest stigma of pauperism connected with this public organisation of industry; and let its internal management be as democratic as may be found consistent with the preservation of order and efficiency. Such an organisation-a little optional co-operative commonwealth, free to every citizen-would become, in all probability, the nucleus of the coming Socialistic State. The standard of comfort in it at first would not be very high ; but, freer from the burden of landlordism and capitalism than the rest of the country, it would be bound to rise rapidly and steadily, and would attract permanently a larger and ever larger proportion of the nation and more and more skilled workers, until well-nigh all the industry and commerce of the country were absorbed into it. ${ }^{1}$

Could there be a more enticing mirage? Solve the problem of the unemployed and establish a Social-Democratic Republic at one stroke! What a contrast to such pettifogging work as slowly and with infinite difficulty building up a Municipal Works Department under the London County Council; fighting to recover, inch by inch, the control of the Thames, the docks and the water supply; puzzling out the means of so perfecting the Mines and Railways Regulation Acts, the Factory and Public Health and Licensing Codes, that the degradation of the standard of life and the manufacture of fresh unemployed may be arrested; discovering how to recover for the use of the whole community an ever larger share of the rent and interest going into idle pockets; organising, educating, and disciplining the workers into Trade Unions; painfully elaborating a network of schools and classes which shall day by day open out to the poorest child in the remotest corner of the realm more of the real treasures of civilisation. Why not drop all this and concentrate our efforts on the simple expediment of persuading a

1 Editorial in Brotherhood, December 1893. 
Parliament of landlords and capitalists to vote the necessary sixty or a hundred and sixty millions sterling, to buy and stock 6,000,000 acres of land on which our out-of-works may be 'freer from the burden of landlordism and capitalism than the rest of the country'? I do not wish to-night to discuss the problem of the Unemployed. It is, I think, probable that, as regards one class of the Unemployed, a term of servitude in an educational Labour colony on a small scale, managed in a proper way, would be the best (though an expensive) means of restoring them to the ranks of productive citizens. But to imagine that any such colony could be self-supporting, that the land which no capitalist will now till with expert farm labourers at ten shillings a week, would yield Trade Union rates of wages to a mixed crowd of unemployed townsmen; that such a heterogeneous collection of waifs and strays, without a common acquaintanceship, a common faith, or a common tradition, could be safely trusted for a single day to manage the nation's land and capital ; finally, to suppose that such a fortuitous agglomeration of undisciplined human atoms offers 'the most suitable and hopeful way of ushering in a Socialist State'-all this argues such a complete misconception of the actual facts of industrial and social life, such an entire misunderstanding of the process by which a Democratic society passes from one stage of its development to another, that I feel warranted in quoting it as an extreme instance of Utopia-founding.

What we Socialists are after is not any clearing out from our midst of those unfortunates who form the reserve army of Labour, even if this were possible, but the organisation of public services in such a way that no such reserve army shall exist. We do not, for instance, want to send unemployed dockers or gas-workers to dig, but so to administer the docks and gasworks that there shall be no such constant fringe of casual labour. To the solution of this problem Utopia-founding, or any other scheme of 'organising the unemployed,' helps just nothing at all. 


\section{Trade Sectionalism}

A more insidious form of Spurious Collectivism is that which makes, consciously or unconsciously, the trade and not the community the unit of administration, and which is expressed in the cry of the land for the labourer, the mine for the miner,-I do not know whether we may add the school for the school-teacher and the sewer for the sewerman.

This Trade Sectionalism is of very old date. It was one of the earliest forms taken by the Socialist movement in this country. Under the system proposed by Robert Owen in I 833 the instruments of production were to :become the property, not of the whole community, but of the particular set of workers who used them. The Trade Unions were to be transformed into 'National Companies' to carry on all the manufactures. The Agricultural Union was to take possession of the land, the Miners' Union of the mines, the textile unions of the factories; each trade being carried on by its particular Trade Union, centralised in one 'Grand Lodge.'

Of all Owen's attempts to reduce his Socialism to practice, this was certainly the very worst. His schemes of factory legislation have raised the standard of life of millions of workers all over the world. For his short-lived communities there was at best the excuse that within their own area the competitive conflict between independent owners was eliminated. But in 'the Trades 'Union' as he conceived it, the mere combination of all the workmen in a trade as, co-operative producers would no more have eliminated commercial competition than a combination of all the employers in it into a joint-stock company. His Grand Lodges would have been simply the head offices of huge companies owning the entire means of production in their industry, and subject to no control by the community as a whole. They would therefore have been in a position at any moment to close their ranks and admit fresh generations of workers only as employees at competitive wages, 
instead of as shareholders, thus creating at one stroke a new capitalist class and a new proletariat. Further, improvident shareholders would soon have begun to sell or pawn their shares in order to spend their capital, finally dropping with their children into the new proletariat; whilst the enterprising and capable shareholders were trafficking in their shares to buy into other and momentarily more profitable trades. Thus there would have been not only a capitalist class and a proletariat, but a speculative stock market. Finally there would have come a competitive struggle between the companies to supplant one another in the various departments of industry. Thus the shipwrights, making wooden ships, would have found the boilermakers competing for their business by making iron ships, and would have had either to succumb or to transform their wooden-ship capital into iron-ship capital and enter into competition with the boilermakers as commercial rivals in the same trade. Moreover, the whole effect of economic rent was entirely overlooked. The fact that the expenditure of labour required to bring articles of the same desirability to market varies enormously according to natural varieties in fertility of soil, distance to be traversed, proximity to good highways, waterways or ports, accessibility of water power or steam fuel, and a hundred other circumstances, including the organising ability and executive dexterity of the producer, was left out of account. Owen assumed that the labour of the miner and that of the agricultural labourer would spontaneously exchange equitably at par of hours and minutes when the miners had received a monopoly of the bowels of the country, and the agricultural labourers of its skin. He did not even foresee that the Miners' Union might be inclined to close its ranks against recruits from the farm labourers, or that the Agricultural Union might refuse to cede sites for the Builders' Union to work upon. 'In short, the difficult economic problem of the equitable sharing of the advantages of superior sites and opportunities never so much as occurred to the enthusiastic adherents of William Thompson's theory, 
afterwards to be elaborated by Karl Marx, that all exchange values could be measured in terms of 'Labour Time' alone. $^{1}$

Now, I do not suggest that we are in danger of any complete revival of Owen's Trade Sectionalism. But I often hear Socialists drop into proposals which tend in that direction. The impatience manifested when it is pointed out that Trade Unions will continue to be necessary in a Social-Democratic State; the reluctance which many Socialists exhibit to regard the Board Schools or Woolwich Arsenal as essentially Socialistic institutions; the proposals occasionally made that the operatives in each trade should elect the managers of it or fix their own hours of labour -all these seem to me to be survivals of Owen's principles, diametrically opposed to modern Socialism. But let me take an actual example from France-a land where all parties are supposed to be more strictly logical in their thinking than those of our compromising island. The other day, Monsieur Goblet, with, as I understand, the concurrence and support of the whole of the Socialist members of the Assembly, proposed, as a Socialist measure, that the present coalowners should, under certain circumstances, be expropriated, and the mines transferred-not to the community as a whole, or to any town or district-but to the men actually working in each mine, who were to divide among themselves the profits hitherto enjoyed by the individual lessees of the mines. I have read a good many notices of this proposal, but I have nowhere seen it pointed out that, so far from being Socialist in character, it is really in direct opposition to Socialist principles. We do not desire to see the mines, and the profits from the mines, transferred to the miners, but to the community as a whole. How far the management should be national and how far local is an unsettled problem of Democratic administration. But to

1 The Owenite Trade Unionism of $1833-34$-the 'New Unionism' of its time - will be found described in The History of Trade Unionism, and incidentally referred to in Industrial Democracy, vol. i. part ii. chap. viii. 
hand over the nation's coal to one particular set of the workers is, in my view, no more a Socialist proposal than the late Sir George Elliot's recent scheme for transferring it to a capitalist syndicate. What we as Socialists look for is, not the assumption by any trade of the management of that trade, but the extension of the public organisation of industry, whether under the Central Government, the County, the Town, or the Parish Council, in the interest of the community as a whole.

\section{JOINT-STOCK INDIVIDUALISM}

If we reject Owen's Trade Sectionalism as a spurious form of Collectivism certain to develop into Joint-Stock Individualism on a large scale, what are we to say to schemes which frankly begin and end with Joint-Stock Individualism on a small scale? The zealous and devoted men who made the Christian Socialist movement of I 848-54, and who got their ideals from Louis Blanc and the Paris Socialists of I 848, sought to replace the capitalist entrepreneur, not by the official of the community, but by little groups of independent workmen jointly owning the instruments of their trade, and co-operating in a 'self-governing workshop.' This dream of co-operative production by associations of producers still lingers vaguely about the trade union world, and periodically captures the imagination of enthusiastic reformers. It is still nominally recognised by the main body of co-operators as one of the ideals of their movement, and it enjoys the very vigorous advocacy of an association of its own. But alike in the trade union and the co-operative worlds, the association of producers, necessarily sectional in principle and working for its own gain, is being rapidly superseded by the contrary ideal of an association of consumers, carrying on industry, not for the profit of the worker, but with the direct object of supplying the wants of the community in the best way. ${ }^{1}$

1 See The Co-operative Movement in Great Britain, by Beatrice Potter (Mrs, Sidney Webb). 
I should have thought there would have been no doubt as to the side that we Socialists should take in this controversy. It may be all very well for a little group of thrifty artisans to club together and set up in business for themselves in a small way. If their venture is prosperous they may find it more agreeable to work under each other's eye than under a foreman. Co-operative production of this sort is at best only a partnership of jobbing craftsmen, with all the limitations and disadvantages of the small industry. From beginning to end it is diametrically opposed to the Socialist ideal. The associated craftsmen produce entirely with a view to their own profit. The community obtains no more control over their industry than over that of an individual employer. They openly compete for business with private firms and other associations of producers. The self-governing workshop belongs, in fact, not to Socialism but to Joint-Stock Individualism. Moreover, in the great majority of existing cases the so-called associations of producers have a darker side. There are capitalist partners who are not workers, and wage-workers who are not partners. In order to increase the gains of the members, their numbers are strictly limited, new hands are taken on at wages often below Trade Union rates, or worse still, work is given out to be done at home on the sweating system. The self-governing workshop becomes, in short, a little partnership of small masters, with all the attendant evils of that decaying form of industrial organisation. The co-operative production of the self-governing workshop appears to me, therefore, spurious Collectivism of a bad type. On the other hand, the cooperative production of the store and the two great co-operative wholesale societies is a genuine step in advance along our own lines. Unfortunately the distinction between the co-operation of associations of consumers, and that of associations of producers, is often misunderstood. We have Socialists and Trade Unionists denouncing the great co-operative organisations of the North of England, with their million of members, and the forty millions sterling of annual trade 
which they have rescued from the profit-maker-denouncing, too, not their incidental shortcomings, but the very principle of their association ; and upholding, on the contrary, what is, I presume, supposed to be the more Socialist principle of profit-sharing or even of the self-governing workshop. The great boot factory, which the million of co-operators have built at Leicester for the supply of their own boots, is attacked on the ground that the profits of the bootmaking are not given to the bootmakers there employed, but are carried to the credit of the whole co-operative community of which the bootmakers can and do form part. The working men of Rochdale or Leeds, who have joined together to organise on a co-operative basis the supply of their own wants, are reproached for not handing over some or all of the annual surplus of receipts over expenditure (for I will not call it profit) to the shop assistants employed in their service. For the life of me I cannot see that this is a Socialist criticism. The whole of our creed is that industry should be carried on not for the profit of those engaged in it, whether masters or men, but for the benefit of the community. We recognise no special right in the miners, as such, to enjoy the mineral wealth on which they work. The Leicester boot operatives can put in no special claim to the profits of the Leicester boot factory, nor the shopmen in a co-operative store to the surplus of its year's trading. It is not for the miners, bootmakers, or shop-assistants, as such, that we Socialists claim the control and the profits of industry, but for the citizens. And it is just because the million cooperators do not, as a rule, share profits with their employees as employees, but only among consumers as consumers; because the control of their industry is vested not in the managers or operatives, but exclusively in the members with one man one vote; and because they desire nothing more ardently than to be allowed in this way to make the whole community co-partners with themselves and participants in their dividend, that their organisation appears to me to be thoroughly Collectivist in principle. 


\section{INDUSTRIAL ANARCHISM}

I suspect, however, that there is something more than confusion of thought in the preference frequently shown by Socialists for the self-governing workshop run by the workers in it over the co-operative factory or municipal works department managed by the representatives of the community. In our capitalist system of to-day there is so much 'niggerdriving,' so many opportunities for petty tyranny, so frequently a bullying foreman, that I do not wonder when working-men look with longing upon an ideal which promises to make them their own masters, if only in a small way. With this feeling every one must sympathise. It is just because the conditions of the industrial servitude of the great mass of the people are so unsatisfactory, that we strive to make them citizens and workers of a Socialist State. But the desire of each man to become his own master is part of the old Adam of Individualism. The time has gone by for carrying on industry by independent producers, such as survive in the cobbler and the knife-grinder, or even by little associations of such producers, like the self-governing workshop in its best form.

Socialists who hanker after these delights have forgotten their Karl Marx. The steam-engine, the factory, and the mine have come to stay; and our only choice is between their management by individual owners or their management by the community. As miner, mechanic, or mill operative, the worker is and must be the servant of the community. From that service Socialism offers no escape: All it can promise is to make the worker, in his capacity of citizen, jointly the proprietor of the nation's industry and the elector of the head officers who administer it. As citizens and electors, the workers, we may presume, will see that the hours of labour are as short, the conditions of work as favourable, and the allowance for maintenance as liberal, as the total productivity of the nation's industry will afford. Organised in their Trade Unions, moreover, the workers in each 
department of the nation's service will know how to make their voice heard by their fellow-citizens against any accidental oppression of a particular trade. ${ }^{1}$

And here I must mention a common misunderstanding of a Socialist phrase, the abolition of the wage-system. Some of our Anarchist friends persist in quoting this as if it implied the entire abolition of the service of one man under the direction of another. To listen to their interpretation one would imagine that they suppose us to contemplate a reversion to the mythical time when every man worked as an independent producer, and enjoyed the whole product of his individual labour. I need hardly say that Socialism involves nothing of the sort. We propose neither to abandon the London and North-Western Railway, nor to allow the engine-drivers and guards to run the trains at their own sweet will, and collect what they can from the verturesome passengers.

By the abolition of the wage-system, we mean the abolition of the system now generally prevailing in the capitalist industry, by which the worker receives a wage not determined with any reference to his quota of the national product, nor with any regard for the amount necessary to maintain him and his family in efficient citizenship, but fixed solely by the competitive struggle. This competitive wage we Socialists seek to replace by an allowance for maintenance deliberately settled according to the needs of the occupation and the means at the nation's command. We already see official salaries regulated, not according to the state of the labour market, but by consideration of the cost of living. This principle we seek to extend to the whole industrial world. Instead of converting every man into an independent producer, working when he likes and as he likes, we aim at enrolling every able-bodied person directly in the service of the community, for such duties and under such kind of organisation, local or national, as may be suitable to his

1 A more complete view of the probable organisation of the Democratic State of the future will be found in the last chapter of Industrial Democracy. 
capacity and social function. In fact, so far are we from seeking to abolish the wage system, so understood, that we wish to bring under it all those who now escape from itthe employers, and those who live on rent or interest, and so make it universal. If a man wants freedom to work or not to work just as he likes, he had better emigrate to Robinson Crusoe's island, or else become a millionaire. To suppose that the industrial affairs of a complicated industrial state can be run without strict subordination and discipline, without obedience to orders, and without definite allowances for maintenance, is to dream, not of Socialism but of Anarchism. ${ }^{1}$

\section{PEASANT PROPRIETORSHIP}

Is it to the influence of this same yearning for industrial anarchism that we. are to attribute the persistence among us of such a spurious form of Collectivism as Peasant Proprietorship? I do not mean Peasant Proprietorship in its crudest form. I suppose that no Socialist desires to see the land of the country divided among small peasant freeholders, though this is still the ideal professed by many statesmen of 'advanced ' views. We are, I hope, all thoroughly convinced that economic rent in all its forms should enrich, not any individual, but the community at large. But it is not difficult to trace, in some of those who are keen advocates of Land Nationalisation, survivals of economic Individualism. We see our esteemed friend, Michael Davitt, lending his influence, not to secure the land of Ireland for the people of Ireland, but to tighten the grip which half a million individual Irishmen have on their particular holdings. Many Scotch comrades, too, seem eager to 'destroy landlordism' by converting the crofter into a freeholder. Even the Land Nationalisation Society cherishes some project of allowing each Englishman, once in his life, to choose for himself a piece of what it professedly desires to obtain for all in

1 See The Impossibilities of Anarchism, by G. Bernard Shaw (Fabian Tract 45). 
common. This seems to me about as reasonable as to propose that each Englishman should be allowed, once in his life, to choose for himself one ship out of the Royal Navy, or that each Londoner should have the right, on his twenty-first birthday, to appropriate for his own use one particular corner of the London parks. The same spurious Collectivism runs through all forms of Leasehold Enfranchisement-a thoroughly reactionary movement which, I am glad to think, is nearly dead. ${ }^{1}$ The agitation for Small Ownings has perhaps more vitality in it; but it is rapidly changing into an agitation for Small Holdings, owned and let by the Parish Council or some other Collectivist organisation. But there are more insidious forms of this Peasant Proprietorship fallacy. What are we to say to comrades who demand that the County Council shall supply artisans' dwellings 'to be let at the cost of construction and maintenance only ?' At present we allow the landlords of London to put into their own pockets sixteen millions a year of annual ground rental of the bare site. If we were to cover London with artisans' dwellings 'let at the cost of construction and maintenance only; we should simply be handing over these sixteen millions of rental value, towards which the labour of all England contributes, to the particular tenants of our new dwellings. How, moreover, if all buildings are to be let at equal rents, are we to equalise the advantages of a flat overlocking Hyde Park and a similar flat out at Holloway? Since we cannot all live on the best sites, those who do must contribute, for the common benefit, the equivalent of the extra advantage they are enjoying. That is to say, a Socialist state or municipality will charge the full economic rent for the use of its land and dwellings, and apply that rent to the common purposes of the community. To follow any other course would be to fall into the Peasant Proprietorship fallacy.

Now I fully agree with those who urge greater unity of action and charity of conduct in the Socialist movement.

1 See The Truth about Leasehold Enfranchisement (Fabian Tract No. 22). 
But we cannot rise above mere denunciation of existing evils, and get that 'body of systematic political thought' which is at present our greatest need, unless we clear up our own ideas. To do this we must, in all friendliness, criticise any proposal that appears to belong to the spurious Collectivism which at present confuses the issue. I hope we may learn scrupulously to abstain from personal abuse or denunciation. I trust we shall avoid imputing motives. But if we are to make any intellectual progress at all, we must have a great deal more frank discussion of the details of the Socialist programme. The movement gains nothing by a complacent toleration of spurious Collectivism. I do not urge the universal adoption by all Socialists of a rigid practical programme complete in all its details. But our one hope of successful propaganda lies in the possession of exact knowledge and very clear ideas of what it is we want to teach. To mix up, under the common designation of Socialism, proposals which tend to Anarchism with those which tend to Collectivism, to accept Democracy and yet to dally with the idea of catastrophic Social Revolution, to confound Utopianism with modern State Socialism, to waver between a trade or workshop sectionalism and ownership by the communityall this argues a confusion of thought which is the worst possible equipment for a successful teacher. If we are to have anything like the success of the early Philosophic Radicals, we must be able, like them, to 'explain in the large dialect of a definite scheme what are our aims and whither we are going.' 



\section{INDEX}

ABILITy, rent of, defined, 215, 217 , 218,223

Acworth, Mr. W. M., I87, I88

Adler, Rev. Hermann, $20 n$.

Adulteration Acts, the, I48, I 5 I

Agricultural Union, the, of Robert Owen, 269, 270

Agriculture, employment of women in, 63

Althorp, Lord, 156

Amsterdam, 20

Argyll, Duke of, $85 n_{\text {., 104, } 105}$

Arnold, Matthew, 250

Ashkenazite Jews, 20, 23 n., 28

Ashley, Lord, I02, I04, I05, II 7

Aylesbury, $60 n$.

BABCEUF, 230

Bakehouses, condition of, I09

Barnett, Rev. Canon, I88

Bastable, Prof. C. F., I30

Basters, 4

Belgian Government, the, and passenger steamers, 247

Belgravia, 214

Bellamy, E., 230

Bentham, Jeremy, I09, I I5, 160, 259

Besant, Sir Walter, 2I 5

Beth Din, the, 21, 22

Bethnal Green, 30, 185, 214

Birminghan, 24I ; trades, employment of women in the, 51; Board of Guardians at, 178

Black Country, the, 99

Black, Miss Clementina, 52 .

Blackburn, I I 7

Blackley, Rev. Canon, 163, I69

Blanc, Louis, 272

Blank, Mr. Joseph, $25 n$.

Blokes, I6

Blyth, 192

Board of Deputies of the British Jews, the, $21,23,23 n$.
Board of Guardians, the Jewish, 27

Boilermakers, 270

Boot and shoe trade, sweating in the, 140,146 ; strike in the, at Leicester, 206 ; wages in the, 238

Bootle, 238

Booth, Mr. Charles, vi, I9 $n_{\text {., }} 20$ n., 32 n., 40 n., 79 n., I09, I 19, I 43 n., I $64 n$., I $74 n$., I 84

Boston, Women's wages at, 48

Bradlaugh, Mr. C., II 5

Bricklayers' Society, the Operative, 197

Bright, John, 84, I05, I07, I I6, 249

British Association, the, 46, 105, 108

Broadhurst, Mr. H., I $74 n$.

Brushmaking, employment of women in, 6I

Bury, 238

Buxton, Mr. Sydney, I 49 n., I 52

CABET, 230

Campanella, 230

Capetown, women compositors at, $6 \mathbf{I}$

Carpenters, Amalgamated Society of, I97

Carpet weaving, employment of women in, 49,58

Chamberlain, Mr. J., 26I

Charity Organisation Society, the, I7 I

Chartism and the New Poor Law, I 56

Chelsea, 185

Chevras (Jewish Societies), 23, 24, 25, $26,33,39$

Chief Rabbi, the, $20 n$., 22, $23 n$.

Christian Socialists, the, 245, 272

Cigar trade, employment of women in the, in London, 51,52 ; at Leeds, 5 I, 5 I $n$.

Clyde Navigation Trust, the, 247

Coalminers' Eight Hours' Bill, the, $103 n$. , 119; strike in 1893 , the, 137 ; Regulation Act of 1887 , the, II9; union, the, 269,270 
Cobden, R., 105, I6o

Collett, Miss Clara, 5I, 51 n., 79 n., 98

Commercial Street, 39

Compositors, London Society of, $59 n$.; employment of women as, in London, 59, 59 n., 77, 95 ; in Lancashire, 60; in Paris, 60; at Warrington, 60 $n$.; at Aylesbury, $60 n$. ; at Redhill, $60 n$.

Co-operation and Trade Unionism, 192-208; on Tyneside, 192 ; associations of consumers, 194; of producers, 195; and the sweating system, 195, 196; limits to the growth of, 199; Trade Unions a necessary adjunct to, 200, 20I ; and the Law of Rent, 203; its duty to Trade Unionism, 204-208

Co-operative Union, the, 207

- Wholesale Societies, 146, 148, 193; cornmills of the, 194; strike at the Leicester Boot Factory of the, 206

Cotton Trade, Lancashire, wages in the, 49, 52, 59; in the United States, 49 ; in France, 53 ; in Yorkshire, 53,54 ; at Glasgow, $53 n$. ; sweating in the, 152

- Weavers, Lancashire, 52, 85, 87, $89,90,97$

Cromer, 197

Cutlery trades, Sheffield, sweating in the, 141,146

DAILY NEWS, the, Paris Correspondent of, 74

Davitt, Mr. Michael, 277

Deputies of British Jews, London Committee of the, 21,23

Derby, Earls of, 238

- Lord, 139

Diminishing returns, the law of, 219 ; applies to capital, 219, 220, 223

Dinner hour, the, 9,18

Disraeli, 6

Dividend, the National, and its distribution, 209-228 ; in economic equilibrium, 209-213; the share of wages, 213.216; of land, 216, 217 ; of ability, 216, 217 ; of interest, 218, 223

Dorsetshire, 78

Dunston Co-operative Cornmill, 195, 196

Durham, 78, 131, 192

EAGLE Brand Boot Works, the, 193

East End. See London

Ede, Rev. W. Moore, I7o
Edinburgh, 47 ; School Board, the, 7I, $79 n$. ; secondary schools at, 72

Eight Hours' Bill, the case for an, I02I 38 ; the, not a new departure, 103I08; what is meant by an, IIO, III ; its advantages over Trade Union action, II3; objections alleged to legislation, II3-II7; the, of the Fabian Society, I18-125; probable economic effects of an, 126-132; common-sense arguments for an, 132136

Movement, the, I03, IO4, Iro, I12, II9

Eleusis Club, the, I60, 175

Eliot, George, 74

Elliot, Sir George, 272

Engineering trade dispute, 1897, 137

Engravers, women, 77

FABIAN Society, the, $46 n$., 118, 122, 123, 182, 254, 255 n., 256

Factory Act, 1802, the, 106 ; of 1844 , 102, 103, 106; of 1860-1864, 107; of 1873,100 ; of 1878,104 ; of 1895 , $82,83,90,91$

Factory and Workshop Regulations, the, 4,13

Legislation, 82-101; the Act of 1895, 82, 91 ; women's objections to, 82,83 ; arguments for and against, 84,85 ; origin of, 85 ; necessity for, $87,88,89$; and Trade Unionism, $89,90,91,100$; and foreign competition, 92 ; unequal applications of, to males and females, 92,93 ; objections to special restrictions on women's work, 93-96; effect of on women, 97, 98, 99; and on little masters, 99, 100; general conclusions upon, IOO, IOI; and the sweating system, I 48 , I 55

man, the, 9, II, I2

Fawcett, Mr. Henry, 108, 257

- Mrs. Henry, 79 n., 83

Forest Gate Poor Law School, the, I75

Forewoman, the, 5

Fox, W. J., I60

France, textile trades in, 53 ; women's earnings in, 78

Freeland, 265

French polishing, employment of women in, $62 n$.

Furniture trades, sweating in the, I4I. 146

Fustian Cutters' Trade Union, the, $5^{8}$; and the employment of women, $5^{8}$ 
GARRET masters, 108

George, Henry, 224, 225

Ghetto, the London, 2

Gibraltar, Post-mistress at, 74

Giffen, Sir Robert, 76, 158

Girls' Public Day School Company, the, 72

Gladstone, Mr. W. E., 105, 257, 258

Glasgow, 50, 53 n., 122 ; textile trades at, 80 n. ; Town Council and lodging houses, 247 ; Town Council and the telephone monopoly, 263

Goblet, Mons., $27 \mathrm{I}$

Goschen, Mr. G. J., 135

Graham, Sir James, I05, I 34

Greener, the, 38, 39, 40, 4I

\section{HACKNEY, 3}

Halesowen, 14I

Heather-Bigg, Miss Ada, 83

Hebrew Ladies' Protective Society, the, 38

Herbert, Mr. Auberon, 235

Home work, 80 n., I44, 145

Houndsditch, 20

Hours of labour, legal regulation of the, IO2-138; origin of movement for the, 103; economic effects of the, 104, 105, 125-138; growth of the, 106-108; present position of the, I09; arguments for further, IIO, II I, II2; its advantages over Trade Union effort, I13-116; and the arguments for liberty, I17, II8; a practicable scheme for the, $118-125$; effects of, on production, 126 ; on wages, 127; on prices, 128, 129; on foreign trade, I30, I31; on particular trades, 132, 133; loss, if any, occasioned by, borne by profits, I34, 135

Huxley, Professc: T. H., 233 n., 250

IMMIGRANTS, Jewish, 32-34; scenes at the landing of, 36,38

Individualism, the difficulties of, 229253; and the evolution of society, 229, 230 ; and social problems, 230, 23I; and collectivism, 231-233; and social reform, 233-235; and inequalities of income, $235 \cdot 237$; and the law of rent, 237, 239; and the population question, 239; effects of, on character, 242; and freedom, 243,245 ; and the growth of collective action, 246, 247; and competition, 247, 248; and the lessons of evolu. tion, 248-250; and liberty, 250253

Ingram, Dr. J. K., 232

Interest, economic, defined, 218, 226, 227 ; and the law of diminishing returns, 219, 220; tendency of rates of, to equality, 22I ; and to a minimum, 224; rates of, and the accumulation of capital, 225

Ireland, handloom weaving in, 54

JACK CADE legislation, rO2, IO4, 134

Jacob, Mr. Joseph, 33 n., $45 n$.

James I., 238

Jevons, Prof. W. S., 215

Jewish Board of Guardians, the, 27, $27 n$. 32, $45 n$.; its origin, 27; its work, 28, 29; its loans, 29, 30

- community, 20-45; settlement in Houndsditch, 20; London Committee of Deputies of British Jews (1760), 21 ; the Beth Din, 22; East End settlement, Chevras, 23, 25; the Jewish Board of Guardians, 27 ; its loan system, 28, 30; Christian conversionist societies, 30 ; temporary shelter, $3 \mathbf{1}$; nationality of East End Jews, 32 ; action of Russia, 33; a typical landing in London, 36 ; a rise in the social scale, 39; education and its effects, 40 ; Jewish character, 4 I

Free School, the, $32 n$.

Jews, the East End, characteristics of, 40-44

Keighley, 198

King James I., 238

\section{LABOUCHERE, Mr. H., IO3}

Labour masters, I

Lancashire, women compositors in, 60; textile workers in, 52, 59, 80 n., 85, $87,89,90,91,97,127,148$

Land Nationalisation Society, the, 277

Land, rent of, 210, $211,226,227$; economic rent of, defined, 213, 217 , 219; and the law of diminishing returns, 219, 221

Land Restoration League, the English, $255 n$.

Laundry-women, 85

Layers-on, women, 62

Leeds, women-workers at, $5 \mathrm{I}$; clothing factories at, 98 ; gasworkers strike at, 200

Leicester, 193, 206 ; co-operative boot factory at, 274 
Leslie Cliffe, 212

Lewis, Island of, 237

Liberal Party, the, and Socialism, 256, 258,260

Liberty and Property Defence League, the, 103, 25I

Linen weaving, employment of women in, 54,57

Linnet, Amy, $60 n$.

Lipton, Sir Thomas, 220

Local Government Board, the, 16I, $162,163,175,180 n ., 182,185,188$

London, East End description of, I, 3 ; the Ghetto of, 2 ; vice in, 8 ; a typical workshop in, 6-19; Jewish settlement in, $20,32,42,45$; foreign Jews in, 33, 36, 40, 140; tailoring trade in, 50, 140 ; cigar makers in, 52 ; compositors in, 59,95 ; brushmakers in, 61 ; ropemakers in, 62; saddlemakers in, 63; Post Office clerks in, 65; School Board for, 70, 71, 73; Factory Acts needed for, 108, I09, I I4, I33; sweating in, I40, 146; pauperism in, 164,167 ; hospitals in, 177; Poor Law administration in, 180-189; building trades in, 197,198

- County Council, and fair wages, $145 n$.; Technical Education Board of the, $176 n$. ; and taxation of ground values, 26I ; work of the, 267

Londonderry, Lord, 203

Lyons, silk manufacture at, 54

Macaulay, Lord, I07, I2I, I27

Machinists, I, 4

Malthusianism, 239, $239 n$.

Manchester, 167, 198; school, the, and Socialisnı, 231, 256

Margin of cultivation, the, 213, 214, 216, 218, 220, 221, 222, 223

Marshall, Professor A., 86, I35, I57, I6I

Martineau, Harriett, I6I

Marx, Karl, 126, I28, 137, 214, 27 I, 275

Marylebone, 187

Massachusetts, 47, 48, 49

Matheson, Lady, 237

M'Corquodale, Messrs., 60

Merchandise Marks Acts, the, I48, I5I

Metropolitan Asylums Board, the, I77, 178, 179, I 88

Michel, Louise, 30

Middlesbrough, 192

Mile End, 20, 187
Mill, John Stuart, 106 n., I15, I16, II 7, I21, I29, I30, 243, 249

- James, 259

Millers' Trade Union, the, 195

Miners. See Coalminers

Mitchell, Mr., 199

Mitre Street, 37

Morley, Mr. John, 105, 106, 107, I19, I21, 232, 259

Mr. Samuel, i 6

Mundella, Mr. A. J., I05, I I4

NaIL Trade, sweating in the, I4I

Newcastle-on-Tyne, School Board, the, 79 n. ; co-operation and Trade Unionism at, 193, 196, 197, 205

Newmarch, Professor, I05

Newton-le-Willows, 60

Nine Hours' Movement, the, I Io, I36

Northampton, 238

Northumberland, coalminers, the, 90 ; co-operation and Trade Unionism in, 192

Nottingham, 205

Notting Hill, 85, II4

ODdFellows, the Manchester Unity of, I 7 I $n$.

Oldham, 89, II 7

Outdoor hands, II, 15

Relief, 158 ; extent of, 159

Overlookers in textile factories, 59

Owen, Robert, 201, 262, 269, 270, 271,272

Oxford, 238

Palestine Place, 30, 31

Paper-mills, employment of women in, 51

Paragon Music Hall, the, I6

Paris, women compositors in, 60, 6I ; correspondent of the Daily News in, 74; Municipal Council of, and burials, I8I; and public bakeries, 247

Pauperism, extent of, I59-I62; among the aged, 163, 164; and old age pensions, 167, 174; and poor law children, 174, 176; and the sick, I77, I79; and the dead, I80; and the casual ward, 182

Peel, Sir Robert, I07

People's Palace, the, 39

Petticoat Lane, 2, 37

Phossy Jaw, 91

Pickersgill, Mr., 187

Plymouth, 247

Poor Jews' Temporary Shelter, the, 32, $3^{8}$ 
Poor Law Commissioners, 1834 , the, 158, 167, 174

Reform of the, 156-191; rise of the present system of, 156 , I 57 ; and the population question, 157 ; extent of out-relief, 158, 159; number of paupers, I6r-164; number of aged paupers, 163 , I64; classification of the pauper class, I66, 167 ; state pensions for the aged, 167-170; provision for pauper children, 174, 176 ; for the sick, I77, I79; for the burial of the dead, 180,182 ; the casual ward, 182-184; machinery of the Poor Law, I84-I9I

Postmaster-General, the, 263

Post Office, wages of male and female clerks in the, 65,66 ; sickness averages of males and females in the, 67 , 68 ; at Gibraltar, the, 74

Potters' Rot, 91

Pottery workers and factory legislation, IO7

Pressers, 1, 4, 5, 7, 9

Prudential Assurance Company, the, employment of women in, 65, 68, 69

RABBI, the Chief, $20 n$., 22, $23 n$.

Railways Regulation Act, 1895 , the, IO3 n., II9

Reading School Board, the, 70

Redhill, $60 n$.

Rẻnan, Mons., 42

Rent. See Ability, Diminishing Returns, Dividend, Interest, and Land

Ricardo, 45, 214

Rochdale, I3I, I48

Roebuck, J. A., I05

Ropemaking, strike of women in the, 62

Round the corner, $16,16 n$.

Roundabout, the, 62

Rousseau, J. J., 103

Runners, 38

Ruskin, Mr. J., 249

Russia and the Jews, 33, 34

Saddlemaking trade, the, 63 .

Saltmaking trade, the, $6 \mathrm{I}$

Salvation Army, the, 17

Schloss, Mr. David, 80 .

School Board for London, the, 70, 71 ; for Reading, 70 ; for Edinburgh, 71

Scotland, women employed in agriculture in, 63 ; miners of, 119

Scottish Co-operative Wholesale Society, the, I 45

Season hands, in the tailoring trade, 2, 10
Senior, Nassau, 84, I26, 257

Sephardic Jews, 20, $23 n$.

Shaftesbury, Lord, 105, 106, I 1 2, 134 , 250,262

Sheffield, 131, I4 I, 146

Shieldhall, I 45

Shipwrights, 270

Sickness, averages of, among male and female officers in Post Offices, 66, 67, 68 ; and in the Prudential Assurance Company, 69

Sidgwick, Prof. H., I 2 I, 135, I 57, 227

Silk manufacture in France, the, 54; in England, 54, 55

Slipper Makers' Society, the, 193

Slop shop, an East End, I-19; de. scription of a, 3, 4; life in a, 4, 5 ; the "missus," $5-7$; dinner hour in a, 8,9 ; scene in a, 9-II; tea time in $\mathrm{a}, \mathrm{12}, \mathrm{13}$; Factory Regulations in a, 12,13 ; types of workers in a, 6 , 8, I4-19

Smiles, Mr. Samuel, 257

Smith, Adam, I03, 224

Smith, Mr. Llewellyn H., 32, 32 n.

Socialism, not a Utopia, 229, 230, 234, $235,255,265-268$; and the Manchester School, 231, 233; and inequalities in wealth, $24 \mathrm{I}-245$; progress of, 246, 249; and liberty, 252 ; and Benthamism, 259, 260 ; and the law of rent, 260 ; and the Factory Acts, 26r, 262; and some pressing problems, 262-264; and Trade Sectionalism, 269-272 ; and the self-governing workshop, 272-274; and the wage system, 275, 277; and peasant proprietorship, 277-279

Society for Promoting Christianity among the Jews, the London, 30; its work, 3I ; and results, 3I, 32

for Promoting the Employment of Women, the, 99

Southwark, 238

Spencer, Mr. Herbert, 261

St. Pancras, I 87

Standard Theatre, the, 16

Stockton, 197

Sunderland, 197

Sweating System, Lords' Committee on the, 104, 140; how to do away with the, I39-155; definition of the, 139-140; causes of the, 140 ; and sub-contract, 140, I4I ; who creates the, 142 ; and the Factory Acts, I4I, 143 ; and alien immigration, $143 n$. ; and homework, 144, 145; co-oper. 
ators and the, 145, 147, I5I ; Legislation and the, 148, I55 ; and co-operative production, 195

TAILORING trade, employment of women in the, in London, 50; at Glasgow, 50 ; at Leeds, 51 ; increase of women workers in the, 98, 99; sweating in the, I40, 145

Task wages of men and women compared, 50; in tailoring, 50 ; in paper mills, 51 ; in Birmingham trades, $5 \mathrm{I}$; in cigar manufacture, $5 \mathrm{I}$; in the textile trades, 52-58; in France, 53 ; in printing trades, 59 , 60 ; in miscellaneous trades, 61,62 , 63 ; general conclusions, 63,64

Taunton, 197

Tea time, the, 12, I8, I9

Teachers, employment of women as, 69, 70; under the London School Board, 70-73 ; at Edinburgh,7 1,72; at Reading, 70 ; in the United States, 73

Technical Education Board of the London County Council, the, $176 n$.

Ten Hours' Bill, the, I03-106, I I 7, I36 ; effects of, in Lancashire and Yorkshire, II 4

Textile trades, employment of women in the, 49 ; in Lancashire, $52-59$; in Yorkshire, 52-59 ; in Glasgow, 52 n. ; in France, 53, 54; in Ireland, 54 ; in Lancashire and Scotland, $80 n$.

Thomas, Mr. Alfred, I73 $n$.

Thompson, William, 270

Time wages of men and women compared, 47 ; in Great Britain, 48, 49 ; in United States, 48, 49

Topolobampo, 265

Trade Unionism, the necessity for, 85 89 ; and co-operation, 192-208; and Associations of Consumers, 194; and Associations of Producers, 195; and the Law of Rent, 203

Trades Union Congress, the, II3, II9, I22, 207, 257

Trimmings, $5,6,7,19$

Trouser finishers, 4

- hands, 3,6

Tyneside, 192, 198, 202

Typewriters, women, 64

UMBRELLA makers, women, 62

Unemployed, the, 263

United Kingdom, women's wages in the, $19,4849,63,64,68$; miners of the, and the Eight Hours' Bill, II9; pauperism in the, I59.164: wealth of the, $245 n$.

United States, the, wages of women in, $48,49,64$; women teachers in, 7.3 ; textile trade in, 76,78 ; factory laws in, II 8

Utopias not Socialism, 229-235, 255, 265-268

Vest Hands, 3, 4, 17

Victoria, Factory Act ot, $150 n$.

WAGES of men and women, for manual labour, compared, $47-64$; for routine mental work, 64 ; in the Post Office, 65-68; in the Prudential Assurance Company, 68, 69; under the School Boards, 69-73 ; for artistic work, 73 ; intellectual work, 74; general conclusions, 74-8I

Economic, definition of, 213, 223 ; their share of the National Dividend, 211, 213-216

Wales, the miners of, II 9

Walker, F. A., 217,224

Wandsworth, I87

Warrington, $60 n$.

Warwickshire, 58

Weavers, women, $55,58,77,85$. See also Textile Trades

White, Mr. Arnold, 25

Whitechapel, $38,45,146$; Board of Guardians, the, I68 n., I69

Whiteley, Mr., 220

Woollen Weavers. See Textile Trades

Women and the Factory Acts, 82-101 ; discussions on the Bill of 1895,82 , 83 ; arguments for and against legislation, 84,85 ; effect of legislation upon, 85-101

Women workers, earnings of unskilled, 19; classification of, 47 ; wages of, 48-59; at various trades, 50-64; at routine mental work, 64-73; have more sickness than men; 67-69; in artistic work, 73; in intellectual work, 74; general conclusions as to earnings of, 74-81 ; effects of legislation upon, 85-10I; competition of, with men, 94,95 ; sweating of, I-1 9 , I 40

Wristdrop, 9I

Wyoming, 73

YORK, 197

Yorkshire textile workers, the, 53-56 


\section{THE HISTORY OF TRADE UNIONISM.}

Revised Edition. Enlarged and extended to 1920.

Pages $\mathrm{xv}$ and 784 .

Price 21s. net.

THIS book, which gives in graphic detail the development of British Trade Unionism from its origin in the $I 7$ th century, has been completely revised with all the latest information, and continued down to the end of the year rgrg. 'The book has been entirely reset so as to permit the fullest revision and the most extensive enlargement, wherever additional information has become available. The fresh matter enlarges the book to nearly twice the size of former editions, and the importance of the additions makes the present issue practically equivalent to a new work.

The story of the dramatic progress of Organised Labour during the past thirty years, including the Revolution in Thought, the Coal and Railway struggles of r9r9, the controversy as to Direct Action, and the rise of the Labour Party, is here described from inside knowledge.

No fewer than 19,000 copies of a special issue of this edition were bought by Trade Unionists in December I9I9 before publication.

Of the various editions of this book it was said that it was "a masterly piece of work" (Times); "to the politician . .. an invaluable guide" (Observer); "a full, clear and condensed history such as can have few parallels . . . a masterpiece of lucidity of knowledge" (Speaker); "readable, every word of it : there is plenty of excitement and plenty of romance in the book" (Queen); "as fascinating reading as a well-written novel" (Cotton Factory Times); an "admirable and masterly work" (Economic Review); "infinitely painstaking, comprehensive, clear and acute, the first correct and scholarly history of Trade Unionism in England. . . . Undeniably marked by the qualities of true history-fulness, accuracy and clear connection in the presentation of facts" (Nerecastle Chronicle). 


\section{OTHER WORKS BY SIDNEY AND BEATRICE WEBB.}

Those who read the History of Trade Unionism will nt to know how far the Trade Union, as an industrial device, is an economic success-how its operations affect the National Being-whether it is a cause of loss to the employers-what effect it has on prices.

These questions, and many more, are explicitly answered in

\section{INDUSTRIAL DEMOCRACY}

12s. net

which The Times described as

"A permanent and invaluable contribution to the sum of human knowledge. . . . We commend to the public a book which is a monument of research and full of candour. . . Indispensable to every publicist and politician."

See also

\section{PROBLEMS OF MODERN INDUSTRY.}

7s. 6 d. net.

Eleven short studies by the same Authors.

\section{THE WORKS MANAGER TO-DAY.}

5s. net.

A series of Addresses to Works Managers by Sidney WEBB on such problems as Reducing Costs, Systems of Payment by Results, How to Prevent "Ca' Canny," Fatigue and Accidents, the Changing Status of Employers and Wage-Earners, etc.

LONGMANS, GREEN \& CO. 


\section{OTHER WORKS BY SIDNEY AND BEATRICE WEBB.}

\section{DHE PUBLIC ORGANISATION OF THE LABOUR MARKET.}

By SIDNEY AND BEATRICE WEBB.

5s. net.

A description and an attempted solution of the Problem of Unemployment and the Unemployed.

\section{THE BREAK-UP OF THE POOR LAW.}

By SIDNEY AND BEATRICE WEBB.

7s. 6d. net.

The Minority Report of the Poor Law Commission. A description of the policy now adopted by the Government in the Bill being prepared by the Minister of Health for the Abolition of the Poor Law, and the Supersession of the Boards of Guardians by the Local Health, Education, Lunacy, Pension, and Unemployment Authorities.

\section{THE PREVENTION OF DESTITUTION.}

By SIDNEY and BEATRICE WEBb.

10 s. net.

A comprehensive and practical programme of how it can be done.

\section{ENGLISH POOR LAW POLICY.}

By SIDNEY AND BEATRICE WEBB.

7s. 6d. net.

The "Missing Link" in histories of the Poor Law-an analysis of the successive transformations of the policy of the Government and the Guardians since the "Principles of I 834."

LONGMANS, GREEN \& CO. 


\section{GRANTS IN AID : A CRITICISM AND A PROPOSAL. \\ By SIDNEY WEBB.}

6s. net.

The only book on this important subject, affecting every Local Government Official and Councillor, and every Ratepayer.

\section{THE PARISH AND THE COUNTY.}

By SIDNEY AND BEATRICE WEBB.

$16 \mathrm{~s}$. net.

A new picture of English Country Life since I689, drawn from original records.

\section{THE MANOR AND THE BOROUGH.}

By SIDNEY AND BEATRICE WEBB.

2 vols. 25s. net.

How the Municipal Boroughs and London Government grew into their present forms.

\section{THE STORY OF THE KING'S HIGHWAY.}

By SIDNEY AND BEATRICE WEBB.

6s. net.

How the English Roads became as they are-from the chariot of Boadicea to the motor omnibus.

\section{THE HISTORY OF LIQUOR LICENSING IN ENGLAND.}

By SIDNEY AND BEATRICE WEBB.

2s. 6d. net.

A record of experiments in policy with regard to the public-house, from Henry VIII.

LONGMANS, GREEN \& CO. 


\section{OTHER WORKS BY SIDNEY AND BEATRICE WEBB.}

\section{PUBLISHED BY \\ GEORGE ALLEN \& UNWIN, LIMITED. \\ THE CO-OPERATIVE MOVEMENT IN GREAT BRITAIN.}

2s. 6 d. net.

By BEATRICE POTTER (Mrs. Sidney Webb).

"Without doubt the ablest and most philosophical analysis of the Co-operative Movement."-The Speaker.

\section{SOCIALISM IN ENGLAND.}

By SIIDNEY WEBB.

2s. 6d. net.

"The best general view of the subject from the moderate Socialist side."-The Athenceum.

Published by THE FABIAN BOOKSHOP (25 TOTHILL Street, Westminster), AND GEORGE ALlEN \& UNWIN, LIMITED.

\section{HOW TO PAY FOR THE WAR.}

Edited by SIDNEY WEBB.

6s. net.

Containing The Development of the Post Office; A Public Service of Railway and Canal Transport, The Nationalisation of the Coal Supply, A State Insurance Department, and a Revolution in the Income Tax. 
OTHER WORKS BY SIDNEY AND BEATRICE WEBB.

PUBLISHED BY THE FABIAN BOOKSHOP (25 TOTHILL Street, Westminster), AND GEORGE ALleN \& UNWIN, LIMITED.

\section{FABIAN ESSAYS IN SOCIALISM.}

2s. net.

The New Edition (50th thousand), with Introduction by Sidney Webb.

\section{TOWARD SOCIAL DEMOCRACY?}

By SIDNEY WEBB.

1s. net.

A survey of Modern Social and Industrial History since 1840 , with a description of tendencies.

\section{MEN'S AND WOMEN'S WAGES : SHOULD}

\section{THEY BE EQUAL?}

By Mrs. SIDNEY WEBB.

With Portrait. 1s. net.

A suggested solution of a difficult problem.

\section{GREAT BRITAIN AFTER THE WAR.}

By SIDNEY WEBB and ARNOLD FREEMAN.

1s. net.

A guide to study of "After-War Problems." 
OTHER WORKS BY SIDNEY AND BEATRICE WEBB.

Published by Nisbet \& CO., Limited.

\section{THE RESTORATION OF TRADE UNION CONDITIONS.}

By SIDNEY WEBB.

1s. net.

A description of the problem and a suggestion for its lasting solution.

Published at THE FABIAN BOOKSHOP (25 Tothill Street, Westminster).

REPORT ON THE WORKING OF THE NATIONAL INSURANCE ACT.

1s. net.

REPORT ON THE DEVELOPMENT OF STATE

AND MUNICIPAL ENTERPRISE ALL OVER THE WORLD.

1s. net.

SOCIALISM AND INDIVIDUALISM.

1s. net.

THE BASIS AND POLICY OF SOCIALISM.

1s. net.

SOCIALISM AND NATIONAL MINIMUM.

1s. net. 






\section{DAY USE \\ RETURN TO DESK FROM WHICH BORROWED

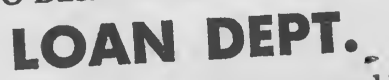

This book is due on the last date stamped below, or

on the date to which renewed.

Renewed books are subject to immediate recall.

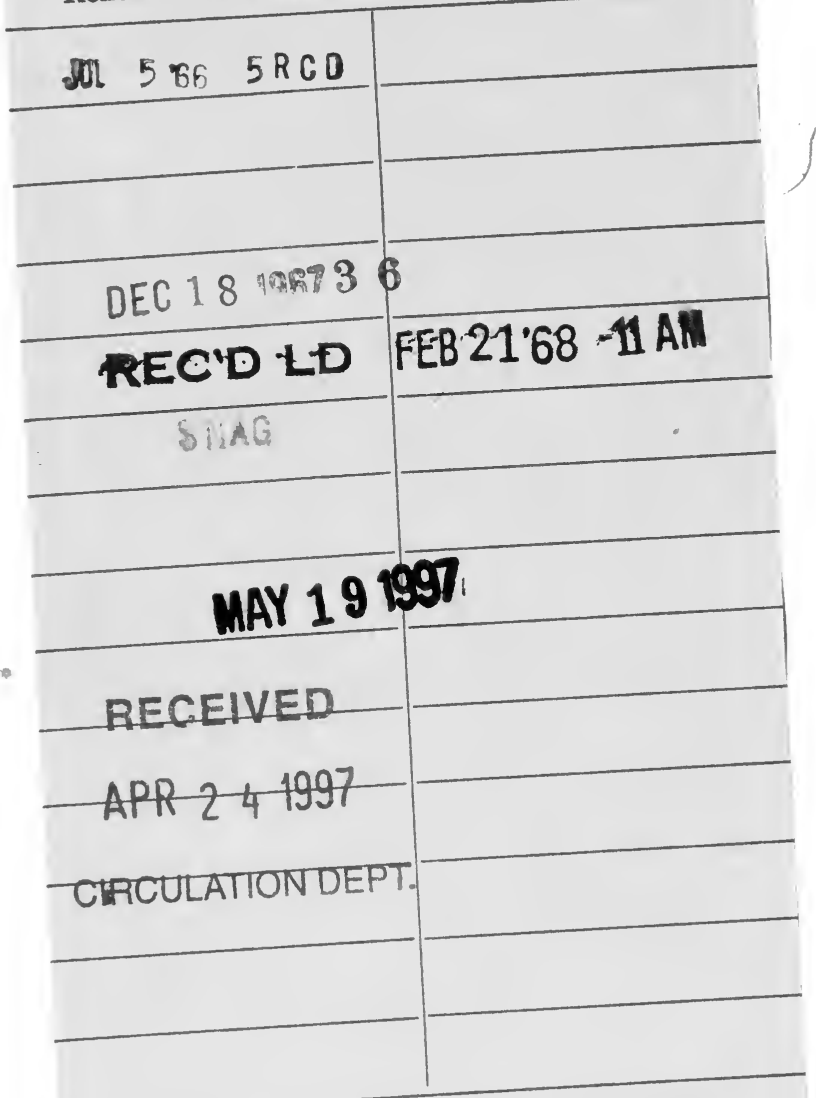


$+$

1.

$x$ 